\title{
PADUCAH GASEOUS DIFFUSION PLANT ANNUAL SITE ENVIRONMENTAL REPORT FOR 1993
}

Project director

F. C. Kornegay

Project coordinator

D. C. West

Technical coordinator

V. W. Jones

Coordinating editor

C. M. Horak

Date Published: October 1994

Prepared by

Environmental, Safety, and Health Compliance and Environmental Management staffs

MARTIN MARIETTA ENERGY SYSTEMS, INC.

P.O. Box 2008

Oak Ridge, Tennessee 37831-6285 and the

Environmental Management Associate Division

Paducah Gaseous Diffusion Plant

MARTIN MARIETTA ENERGY SYSTEMS, INC.

P.O. Box 1410

Paducah, Kentucky 42001 for the

U.S. DEPARTMENT OF ENERGY

under contract No. DE-AC05-84OR21400 and

MARTIN MARIETTA UTILITY SERVICES, INC. for the

UNITED STATES ENRICHMENT CORPORATION under contract No. DE-AC05-76OR00001

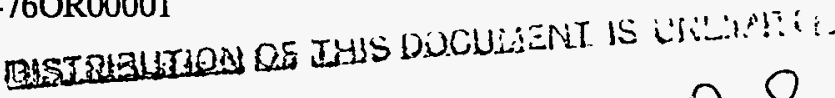




\section{DISCLAIMER}

This report was prepared as an account of work sponsored by an agency of the United States Government. Neither the United States Government nor any agency thereof, nor any of their employees, make any warranty, express or implied, or assumes any legal liability or responsibility for the accuracy, completeness, or usefulness of any information, apparatus, product, or process disclosed, or represents that its use would not infringe privately owned rights. Reference herein to any specific commercial product, process, or service by trade name, trademark, manufacturer, or otherwise does not necessarily constitute or imply its endorsement, recommendation, or favoring by the United States Government or any agency thereof. The views and opinions of authors expressed herein do not necessarily state or reflect those of the United States Government or any agency thereof. 


\section{DISCLAIMER}

Portions of this document may be illegible in electronic image products. Images are produced from the best available original document. 


\section{Department of Energy \\ Oak Ridge Operations \\ P.O. Box 2001 \\ Oak Ridge, Tennessee 37831 - \\ October 11, 1994}

\section{Distribution}

\section{PADUCAH ANNUAL SITE ENVIRONMENTAL REPORT FOR CALENDAR YEAR 1993}

Enclosed for your information is a copy of the Paducah Annual Site Environmental Report for 1993. This report includes the results from on-site and off-site environmental monitoring activities, describes actions to comply with environmental regulations, and discusses the overall environmental impacts of Department of Energy (DOE) activities on the surrounding area. This report is prepared annually for distribution to the public: news media: and local. state, and federal agencies. The report was prepared for the DOE by our contractor Martin Marietta Energy Systems. Inc. (Energy Systems).

This years report is somewhat different than previous reports. An attempt was made to streaml ine the document and provide more summary information. The detailed data has been incorporated into a separate report. Likewise, a summary "pamphlet" is available this year. Its purpose is to convey key environmental monitoring information to those without a technical background. Comments on this report are welcome. All comments will be considered during the writing of the next report. There is a comment sheet and mailing address at the end of the report.

The monitoring data and subsequent data analyses have been collected and performed in accordance with controlled operating procedures. Likewise, both DOE and Energy Systems personnel have reviewed this document for accuracy. To the best of my knowledge, this report accurately summarizes and discusses the results of the 1993 environmental monitoring program.

If you have any questions or desire additional information, please contact David Tidwel1 at 502-441-6807 or James Donnelly at 615-574-6260.

Sincerely.

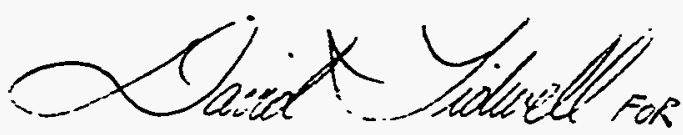

J. C. Hodges, Site Manager

Paducah Site Office

Enclosure 
Cc w/enclosure:

R. C. Sleeman. EW-91

D. Tidwe 11, EF-22

E. W. Gillespie, EF-21

P. J. Gross, SE-31

R. Natoli, EH-22, HQ/FORS (5 copies)

R. Sharma, NE-47, HQ/GTN 


\section{Paducah Gaseous Diffusion Plant Annual Site Environmental Report Summary for 1993 (ES/ESH-54, KY/ERWM-19) Comment Sheet}

This summary is the first such document published in addition to the annual site environmental report (ASER). The writers and production staff welcome comments, all of which will be considered during the writing of the next report summary. Please fill out this sheet and fax it to 615-574-6965 or mail it to the following address:

PGDP ASER Editorial Office

P.O. Box 2008

Mail Stop 6146

Oak Ridge, TN 37831-6146

Keep my name on the PGDP ASER Summary mailing list.

Add my name to the PGDP ASER Summary mailing list.

Remove my name from the PGDP ASER Summary mailing list.

Comments:

Name

Organization 


\section{Paducah Gaseous Diffusion Plant Annual Site Environmental Report for 1993 \\ (ES/ESH-53, KY/ERWM-18) \\ Comment Sheet}

The annual site environmental report (ASER) is undergoing a transition to a more concise, singlevolume format. The writers and production staff welcome comments, all of which will be considered during the writing of the next report. Please fill out this sheet and fax it to 615-574-6965 or mail it to the following address:

PGDP ASER Editorial Office

P.O. Box 2008

Mail Stop 6146

Oak Ridge, TN 37831-6146

Keep my name on the PGDP ASER mailing list.

Add my name to the PGDP ASER mailing list.

Remove my name from the PGDP ASER mailing list.

Comments:

$\begin{array}{ll}\text { Name } & \text { Organization }\end{array}$

City, State

Zip Code 


\section{Contents}

List of Figures $\ldots \ldots \ldots \ldots \ldots \ldots \ldots \ldots \ldots \ldots \ldots \ldots \ldots \ldots \ldots \ldots \ldots \ldots \ldots \ldots$

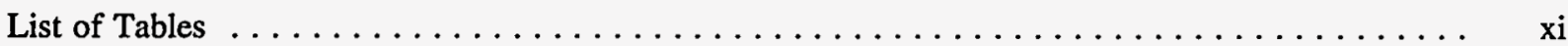

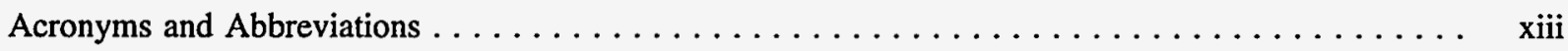

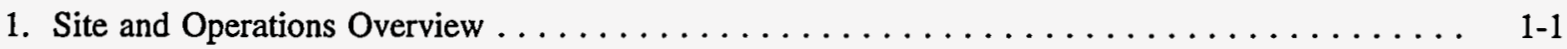

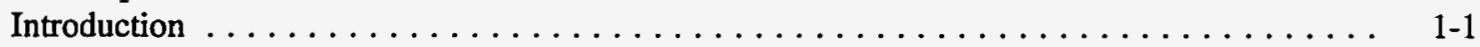

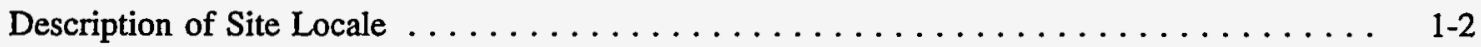

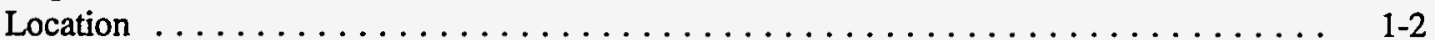

Climate ............................... 1-2

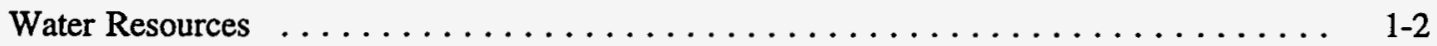

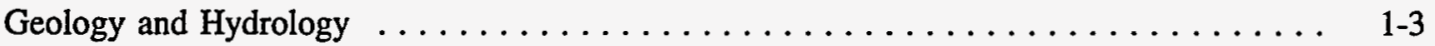

Ecological Resources . . . . . . . . . . . . . . . . .

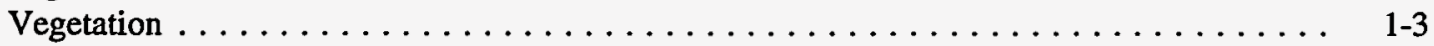

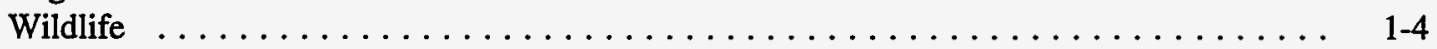

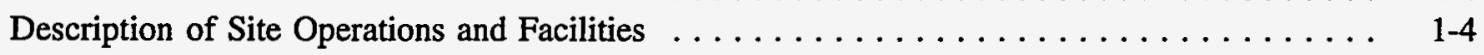

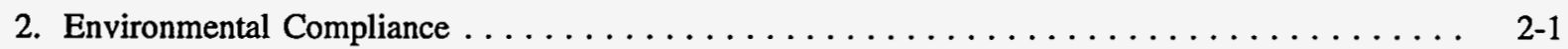

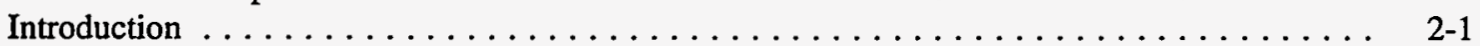

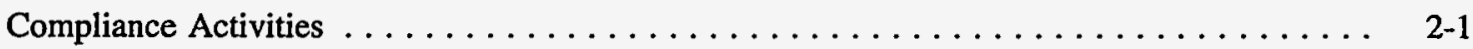

RCRA ............................. 2-1

Superfund Amendments and Reauthorization Act (SARA) ............ 2-3

Comprehensive Environmental Response, Compensation, and

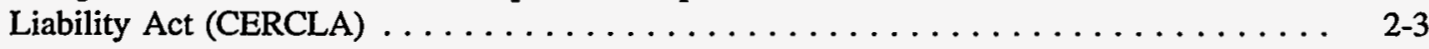

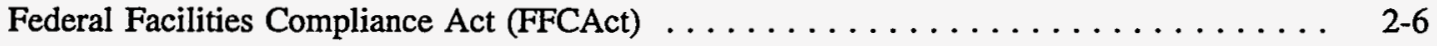

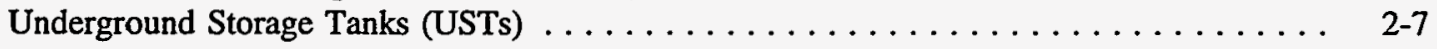

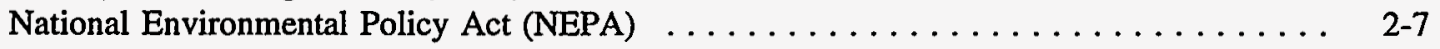

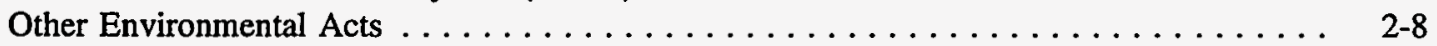

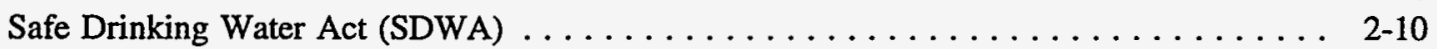

Clean Water Act (CWA) . . . . . . . . . . . . . . . . . . . . . . 2-10

Toxic Substances Control Act (TSCA) . . . . . . . . . . . . . . . . . 2-10

Federal Insecticide, Fungicide, and Rodenticide Act (FIFRA) $\ldots \ldots \ldots \ldots \ldots \ldots$ 2-12

Emergency Planning and Community Right-To-Know Act (EPCRA) . . . . . . . . 2-12

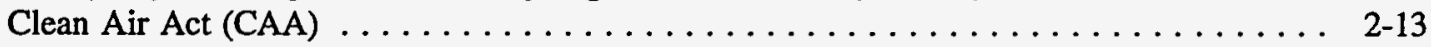

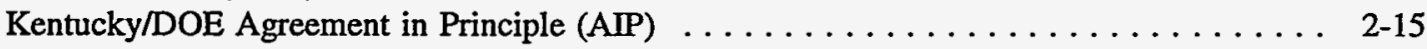

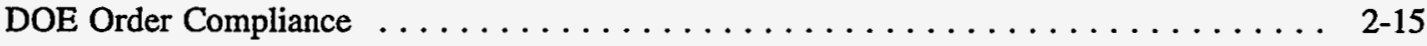

Assessments .................................. 2-17

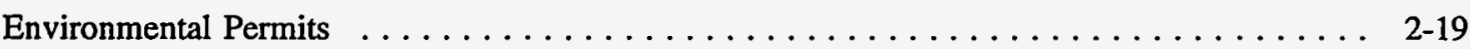

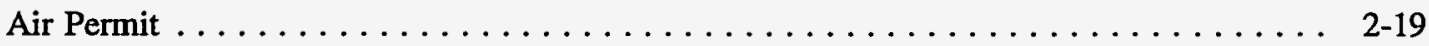

RCRA Permits ............................... 2-19

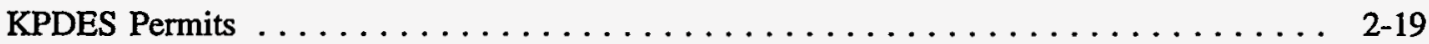

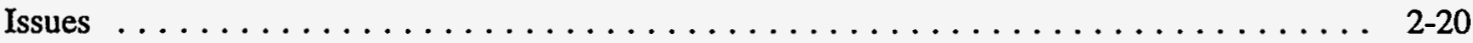

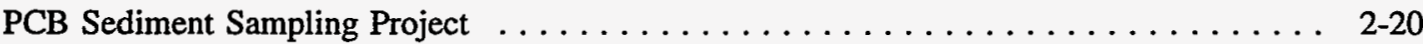

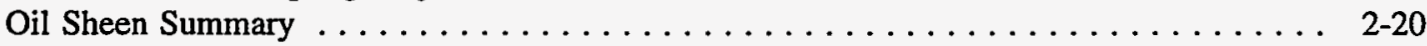

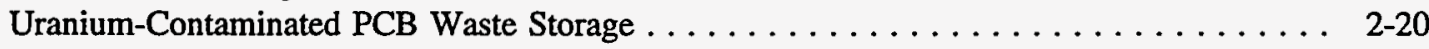

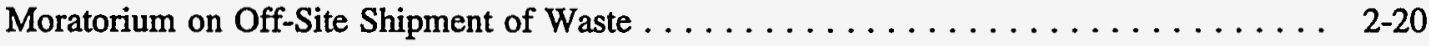

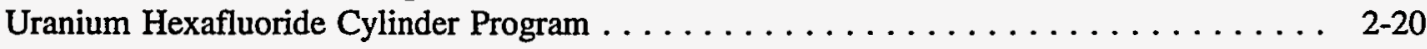




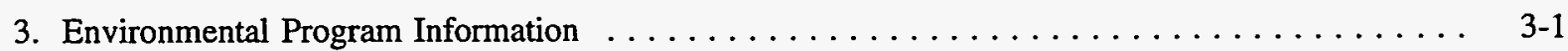

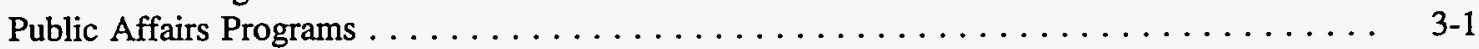

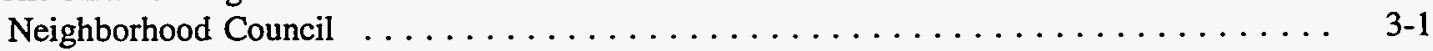

Information Bulletins/Fact Sheets/Public Briefings $\ldots \ldots \ldots \ldots \ldots \ldots \ldots \ldots \ldots \ldots$ 3-1

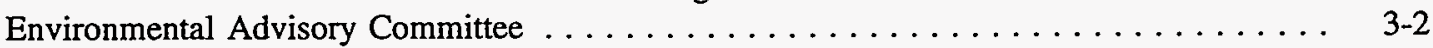

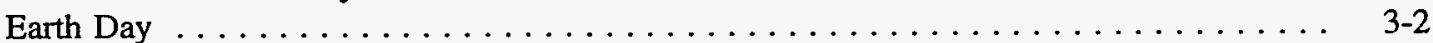

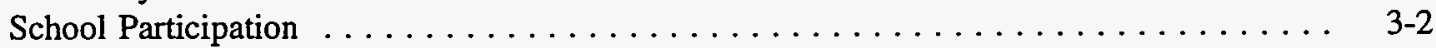

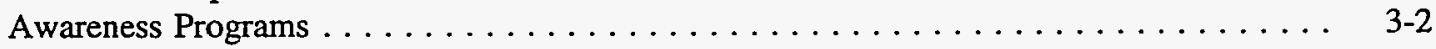

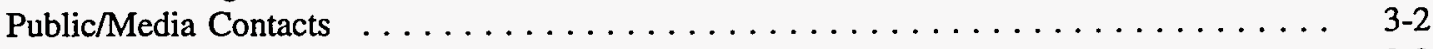

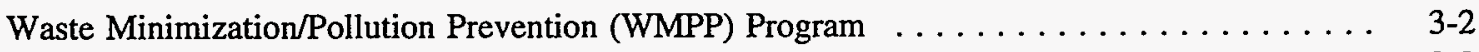

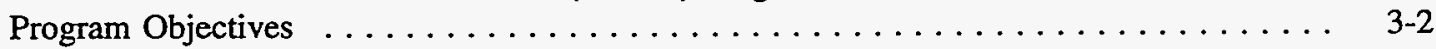

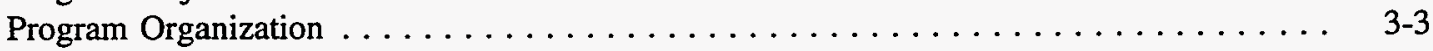

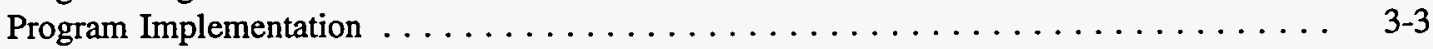

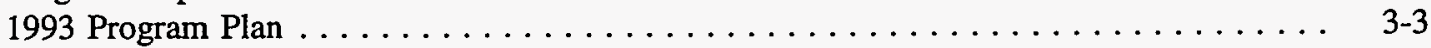

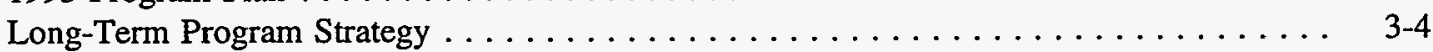

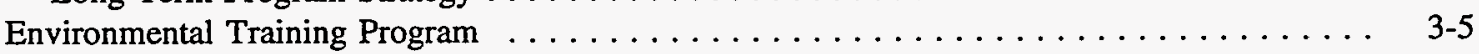

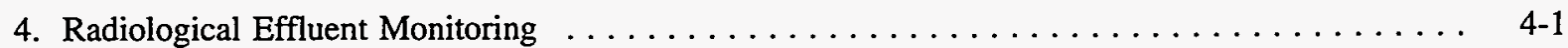

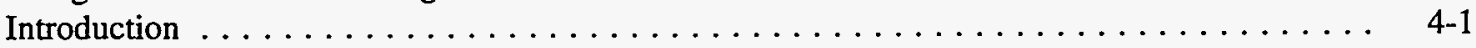

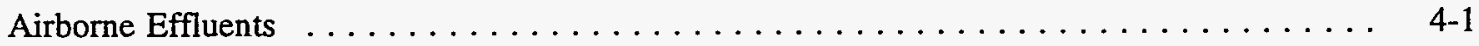

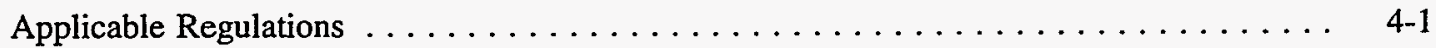

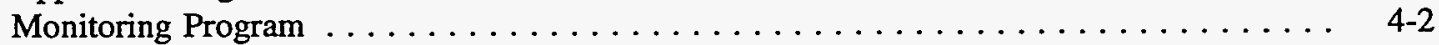

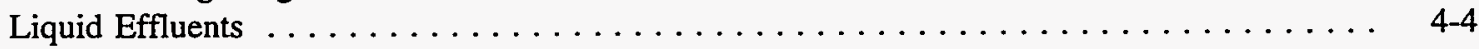

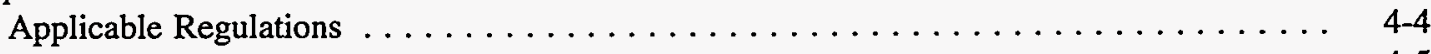

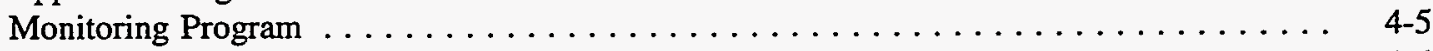

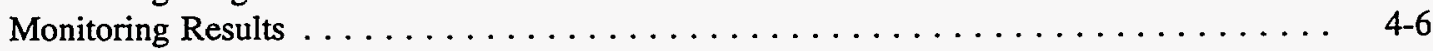

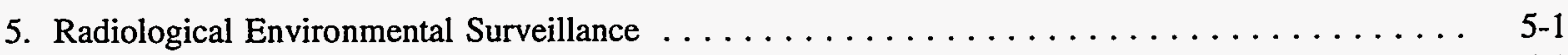

Ambient Air . . . . . . . . . . . . . . . .

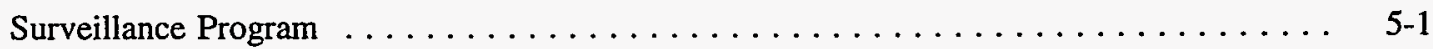

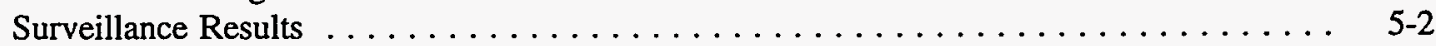

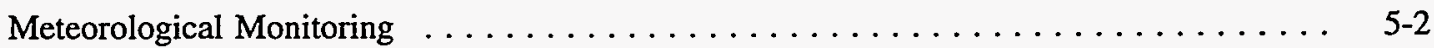

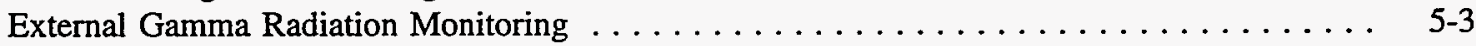

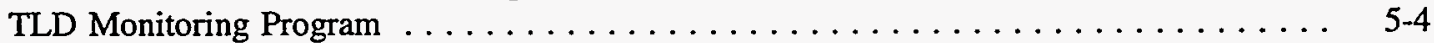

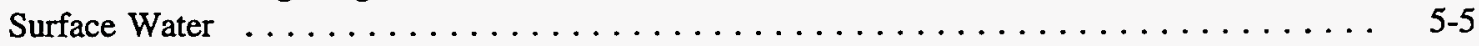

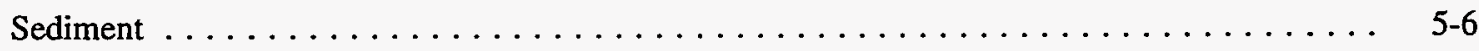

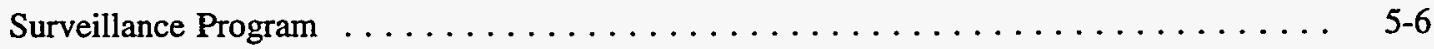

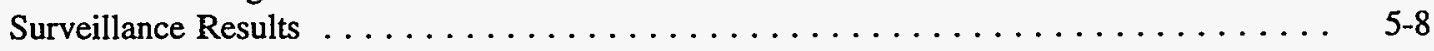

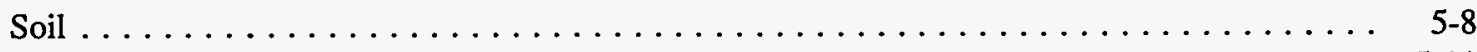

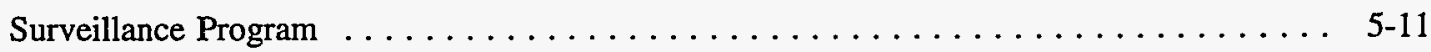

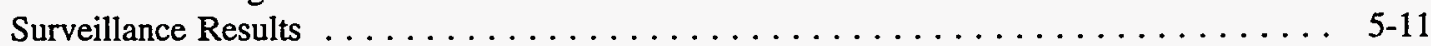

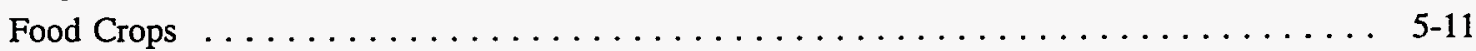

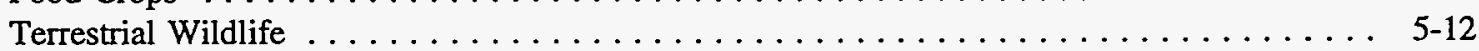

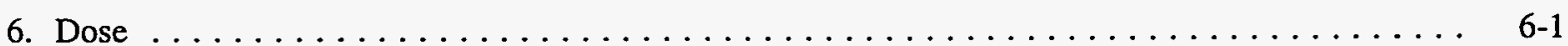

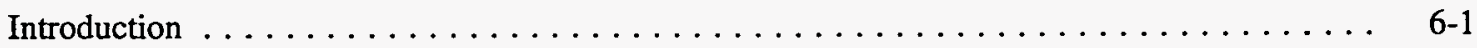

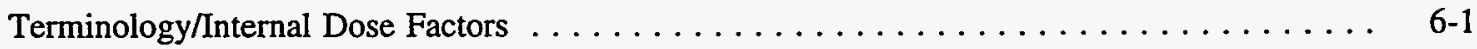

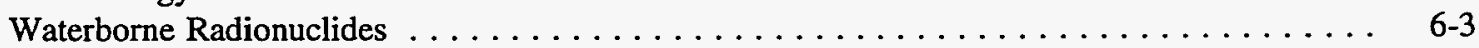

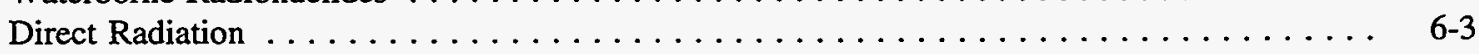

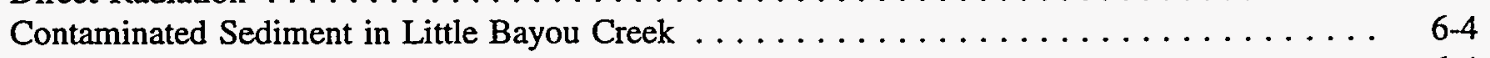

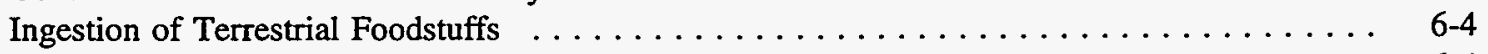

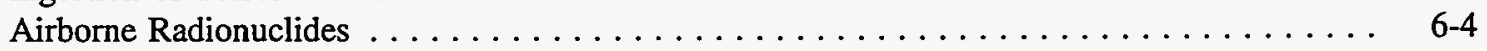

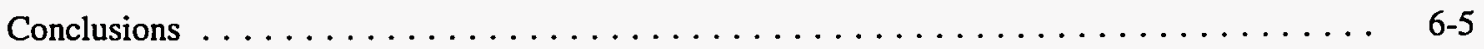




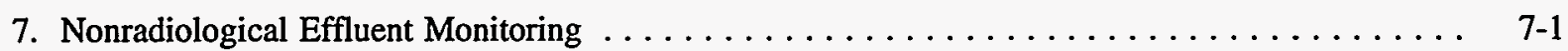

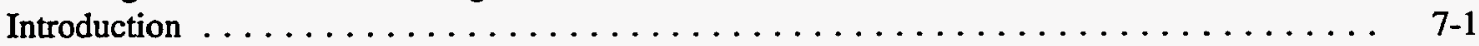

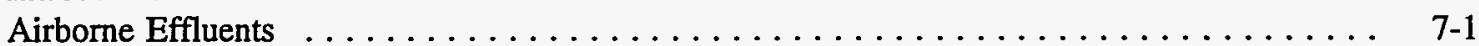

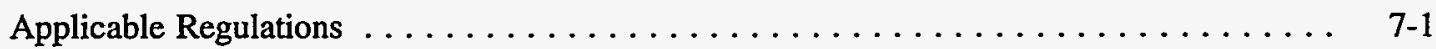

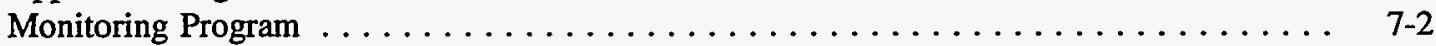

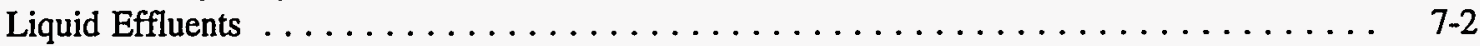

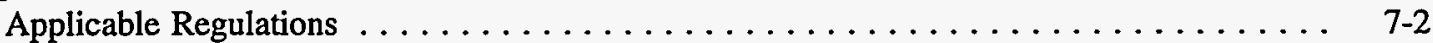

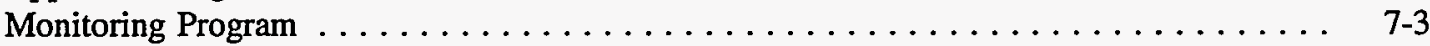

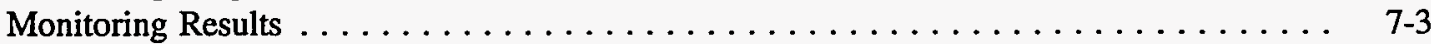

8. Nonradiological Environmental Surveillance $\ldots \ldots \ldots \ldots \ldots \ldots \ldots \ldots \ldots \ldots \ldots \ldots \ldots$ 8-1

Ambient Air . . . . . . . .

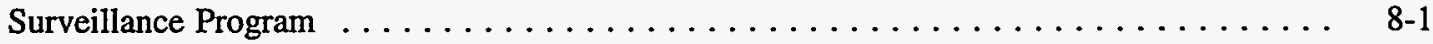

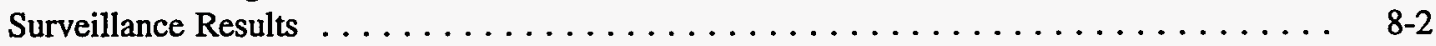

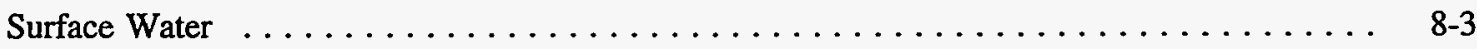

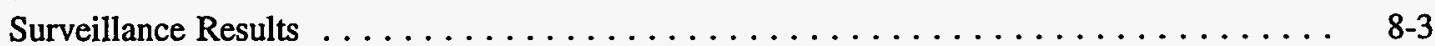

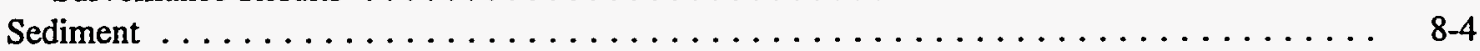

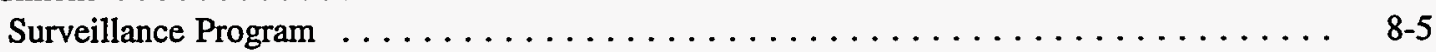

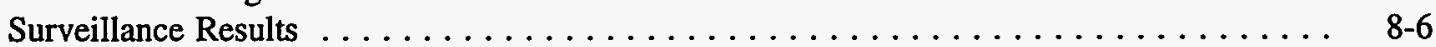

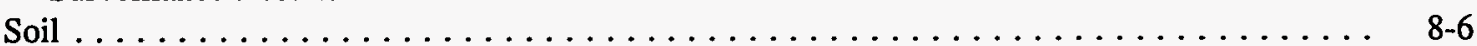

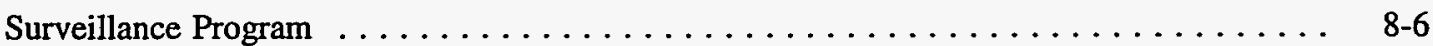

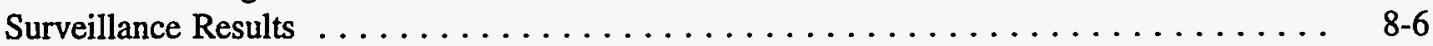

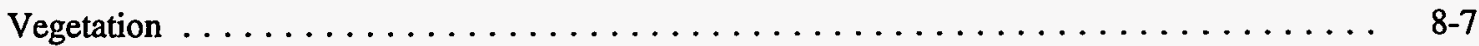

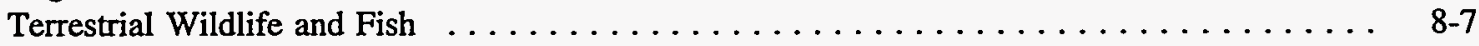

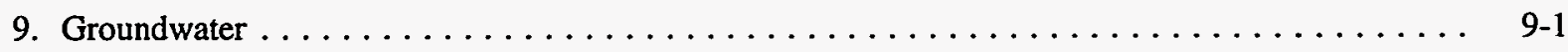

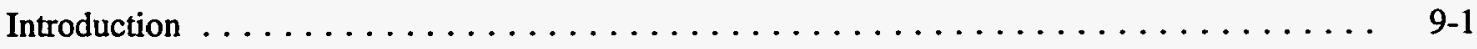

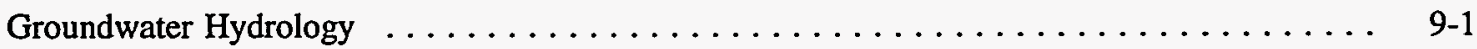

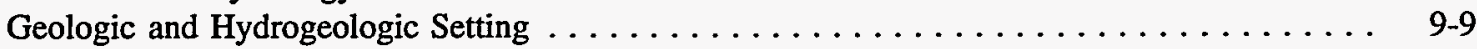

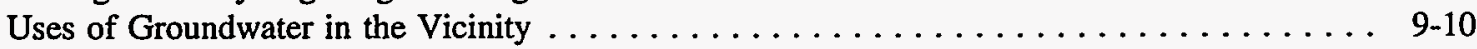

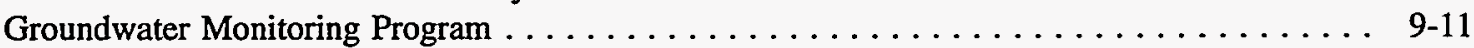

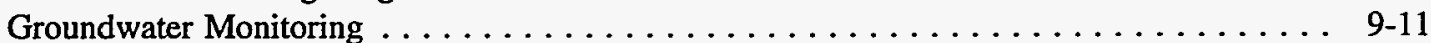

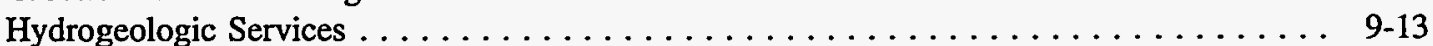

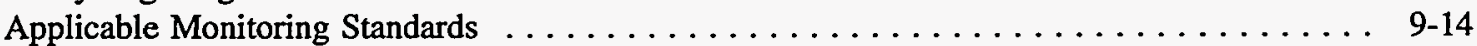

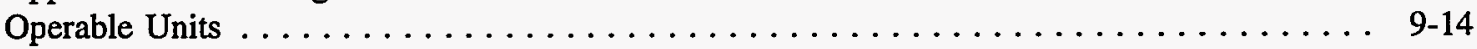

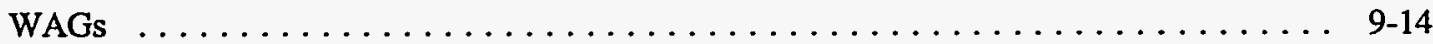

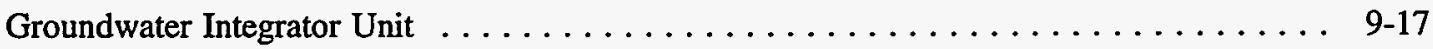

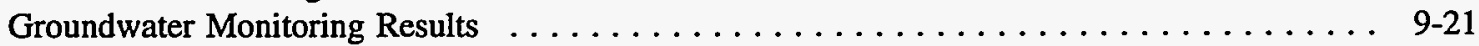

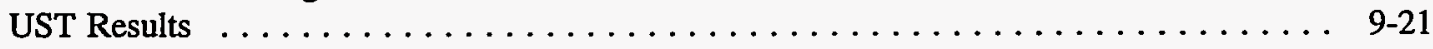

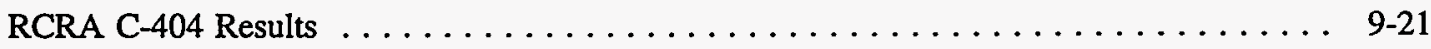

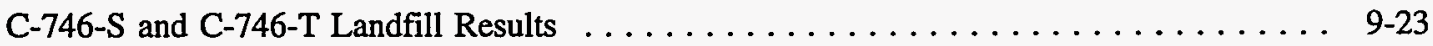

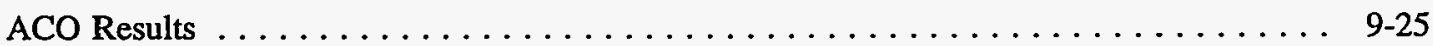

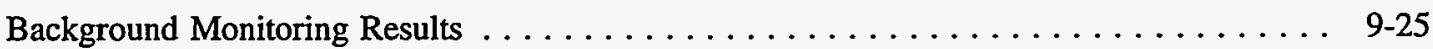

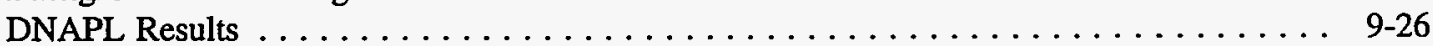

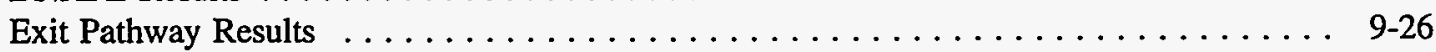

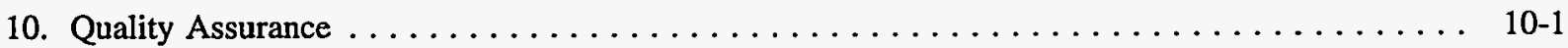

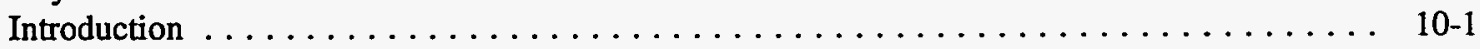

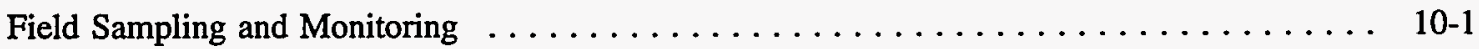

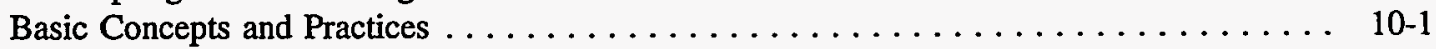

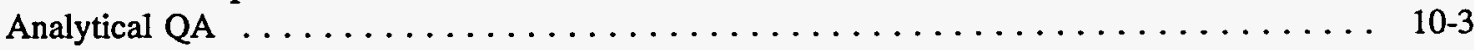

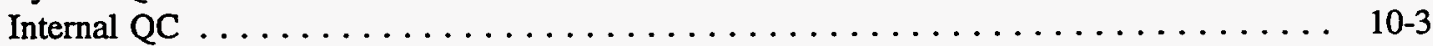

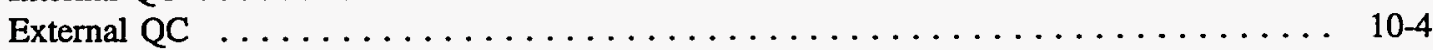

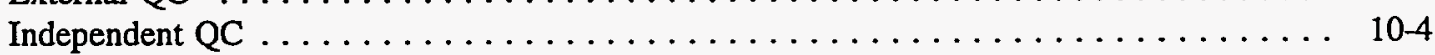

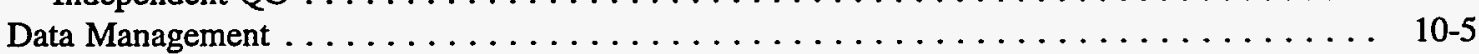




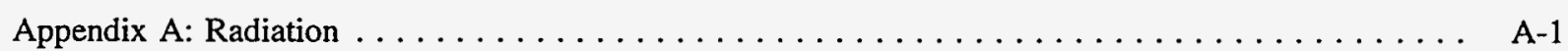

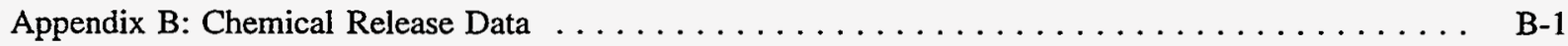

Appendix C: Radionuclide and Chemical Nomenclature $\ldots \ldots \ldots \ldots \ldots \ldots \ldots \ldots \ldots \ldots \ldots \ldots$

Appendix D: Errata for the Paducah Gaseous Diffusion Plant Environmental Report

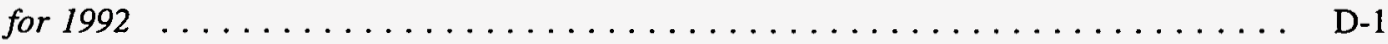

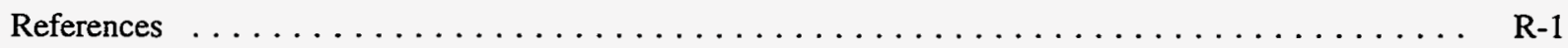

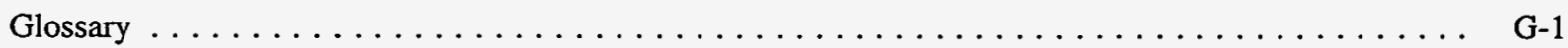




\section{List of Figures}

Figure

1.1 Location of the Paducah site in Kentucky $\ldots \ldots \ldots \ldots \ldots \ldots \ldots \ldots \ldots \ldots \ldots \ldots \ldots \ldots \ldots$

1.2 Location of PGDP in relationship to the geographic region $\ldots \ldots \ldots \ldots \ldots \ldots \ldots$

1.3 Typical stage arrangement at the junction of two cells in the gaseous diffusion process for enriching uranium $\ldots \ldots \ldots \ldots \ldots \ldots \ldots \ldots \ldots \ldots$

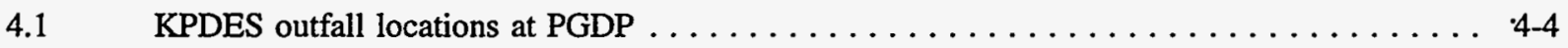

4.2 Surface water monitoring locations at PGDP $\ldots \ldots \ldots \ldots \ldots \ldots \ldots \ldots \ldots \ldots \ldots$

4.3 Uranium discharges to surface water, $1989-1993 \ldots \ldots \ldots \ldots \ldots \ldots \ldots \ldots$

4.4 Technetium-99 discharges to surface water, $1989-1993 \ldots \ldots \ldots \ldots \ldots \ldots \ldots \ldots$

$5.1 \quad$ Air sampling and meteorological monitoring stations at PGDP $\ldots \ldots \ldots \ldots \ldots \ldots$

5.2 Wind rose (10-m level) showing the wind speed frequency distribution data (with $93.1 \%$ of possible data) used for the 1992 estimates $\ldots \ldots \ldots \ldots \ldots \ldots$. $\ldots \ldots$

5.3 Wind rose (60- $\mathrm{m}$ level) showing the wind speed frequency distribution data (with $93.1 \%$ of possible data) used for the 1992 estimates . . . . . . . . . . . 5-4

$5.4 \quad$ Thermoluminescent dosimeter locations at PGDP $\ldots \ldots \ldots \ldots \ldots \ldots \ldots \ldots \ldots$

5.5 Quality control thermoluminescent dosimeter locations at PGDP $\ldots \ldots \ldots \ldots \ldots \ldots$

$5.6 \quad$ PGDP external gamma radiation, $1989-1993 \ldots \ldots \ldots \ldots \ldots \ldots \ldots \ldots \ldots \ldots$

$5.7 \quad$ Surface water monitoring locations at PGDP $\ldots \ldots \ldots \ldots \ldots \ldots \ldots \ldots \ldots \ldots$

$5.8 \quad$ Routes of trace metals in an aquatic ecosystem $\ldots \ldots \ldots \ldots \ldots \ldots \ldots \ldots \ldots \ldots$

$5.9 \quad$ Soil and sediment sampling locations at PGDP $\ldots \ldots \ldots \ldots \ldots \ldots \ldots \ldots \ldots \ldots \ldots$

$5.10 \quad$ Food crop collection locations near PGDP $\ldots \ldots \ldots \ldots \ldots \ldots \ldots \ldots \ldots \ldots \ldots \ldots$

6.1 Possible pathways between radioactive material released to the

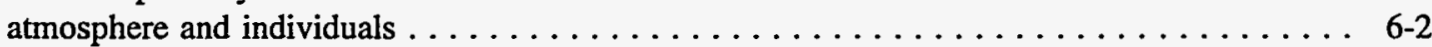

6.2 Possible pathways between radioactive material released to

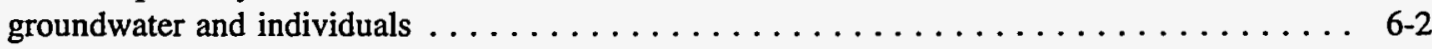

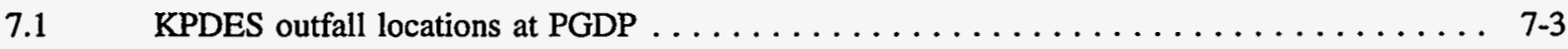

7.2 Surface water monitoring locations at PGDP $\ldots \ldots \ldots \ldots \ldots \ldots \ldots \ldots \ldots \ldots \ldots$

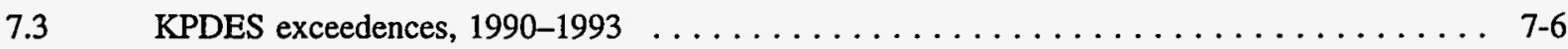

8.1 Air sampling and meteorological monitoring stations at PGDP $\ldots \ldots \ldots \ldots \ldots \ldots \ldots$ 


\section{Paducah Gaseous Diffusion Plant}

S.2 Surface water monitoring locations at PGDP $\ldots \ldots \ldots \ldots \ldots \ldots \ldots \ldots \ldots$

8.3 Routes of trace metals in an aquatic ecosystem $\ldots \ldots \ldots \ldots \ldots \ldots \ldots \ldots \ldots$

$8.4 \quad$ Soil and sediment sampling locations at PGDP $\ldots \ldots \ldots \ldots \ldots \ldots \ldots \ldots \ldots$

8.5 Gass sampling locations at PGDP $\ldots \ldots \ldots \ldots \ldots \ldots \ldots \ldots \ldots \ldots \ldots \ldots \ldots$

9.1 Wells sampled by PGDP in 1993 (by sectors) $\ldots \ldots \ldots \ldots \ldots \ldots \ldots \ldots \ldots \ldots$

9.2 Wells sampled by PGDP in 1993 -northwest sector $\ldots \ldots \ldots \ldots \ldots \ldots \ldots \ldots$

9.3 Wells sampled by PGDP in 1993 -northeast sector $\ldots \ldots \ldots \ldots \ldots \ldots \ldots \ldots \ldots$

9.4 Wells sampled by PGDP in 1993 -southwest sector $\ldots \ldots \ldots \ldots \ldots \ldots \ldots \ldots \ldots$

9.5 Wells sampled by PGDP in 1993 -southeast sector $\ldots \ldots \ldots \ldots \ldots \ldots \ldots \ldots \ldots$. 9.6

9.6 Wells sampled by PGDP in 1993 -plant site $\ldots \ldots \ldots \ldots \ldots \ldots \ldots \ldots \ldots \ldots$

9.7 Monitoring well construction showing relationship between screened zone and water level in well where the limited flow through the

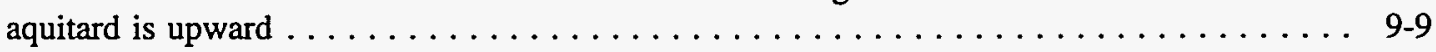

9.8 Schematic of north-south section showing regional stratigraphic relationships at PGDP (from Phase III Groundwater Investigation) . . . . . . . . . . .

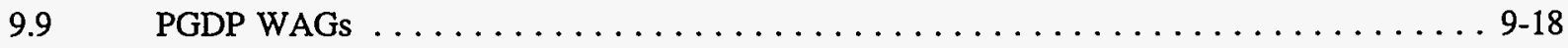

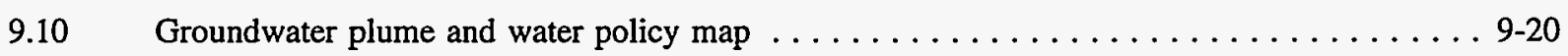

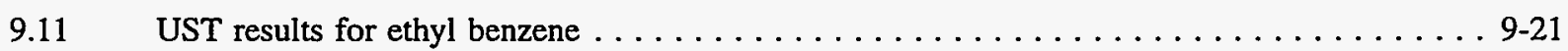

$9.12 \quad$ UST results for xylene $\ldots \ldots \ldots \ldots \ldots \ldots \ldots \ldots \ldots \ldots \ldots \ldots \ldots \ldots \ldots \ldots \ldots \ldots \ldots .21$

9.13 Background C-404 TCE results for the RGA $\ldots \ldots \ldots \ldots \ldots \ldots \ldots \ldots \ldots \ldots \ldots \ldots \ldots \ldots .22$

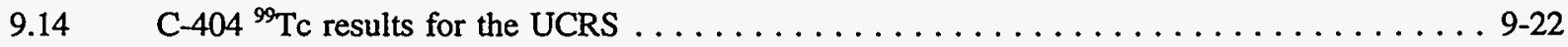

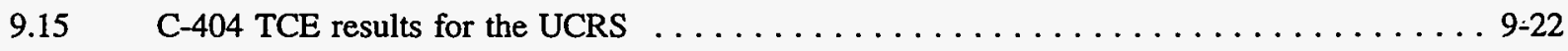

$9.16 \quad \mathrm{C}-404{ }^{99} \mathrm{Tc}$ results for the RGA $\ldots \ldots \ldots \ldots \ldots \ldots \ldots \ldots \ldots \ldots \ldots \ldots \ldots \ldots \ldots \ldots \ldots \ldots .22$

$9.17 \quad \mathrm{C}-746-\mathrm{S}$ and C-746-T, ${ }^{99} \mathrm{Tc}$ monitoring of the UCRS $\ldots \ldots \ldots \ldots \ldots \ldots \ldots \ldots \ldots$

9.18 Background C-746-S and C-746-T ${ }^{99} \mathrm{Tc}$ results for the RGA (plot 1$) \ldots \ldots \ldots \ldots$ 9-23

9.19 C-746-S and C-746-T ${ }^{99} \mathrm{Tc}$ results for the RGA (plot 2$) \ldots \ldots \ldots \ldots \ldots \ldots \ldots \ldots$

$9.20 \quad$ C-746-S and C-746-T TCE results for the RGA (plot 2) $\ldots \ldots \ldots \ldots \ldots \ldots \ldots \ldots$

$9.21 \quad \mathrm{C}-746-\mathrm{S}$ and $\mathrm{C}-746-\mathrm{T}{ }^{99} \mathrm{Tc}$ results for the RGA (plot 3$) \ldots \ldots \ldots \ldots \ldots \ldots \ldots \ldots$

9.22 C-746-S and C-746-T TCE results for the RGA (plot 3$) \ldots \ldots \ldots \ldots \ldots \ldots \ldots$ 
$9.23 \quad \mathrm{C}-746-\mathrm{S}$ and $\mathrm{C}-746-\mathrm{T}{ }^{99} \mathrm{Tc}$ results for the RGA (plot 4) $\ldots \ldots \ldots \ldots \ldots \ldots \ldots .9 .24$

9.24 C-746-S and C-746-T TCE results for the RGA (plot 4) $\ldots \ldots \ldots \ldots \ldots \ldots \ldots \ldots$ 9-24

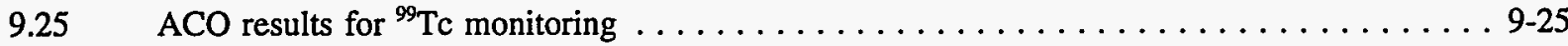

$9.26 \quad$ ACO results for TCE monitoring $\ldots \ldots \ldots \ldots \ldots \ldots \ldots \ldots \ldots \ldots \ldots \ldots \ldots \ldots \ldots \ldots \ldots \ldots .25$

9.27 Background monitoring results for ${ }^{99} \mathrm{Tc}$ in the UCRS $\ldots \ldots \ldots \ldots \ldots \ldots \ldots \ldots \ldots$

9.28 Background monitoring results for ${ }^{99} \mathrm{Tc}$ in the RGA $\ldots \ldots \ldots \ldots \ldots \ldots \ldots \ldots \ldots \ldots \ldots$

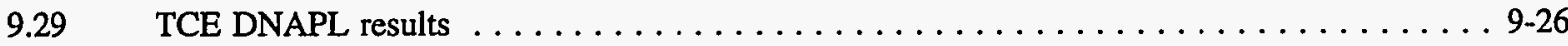

9.30 Exit pathway ${ }^{99} \mathrm{Tc}$ results in the UCRS - northeast of PGDP
farther than $3000 \mathrm{ft}$ from the site $\ldots \ldots \ldots \ldots \ldots \ldots \ldots \ldots \ldots \ldots \ldots \ldots \ldots \ldots \ldots$

9.31 Exit pathway ${ }^{99} \mathrm{Tc}$ results in the RGA-northeast of PGDP

farther than $3000 \mathrm{ft}$ from the site $($ plot 1$) \ldots \ldots \ldots \ldots \ldots \ldots \ldots \ldots \ldots \ldots \ldots \ldots \ldots \ldots \ldots .26$

9.32 Exit pathway ${ }^{99} \mathrm{Tc}$ results in the RGA-northeast of PGDP

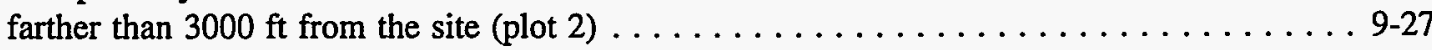

9.33 Exit pathway TCE results in the RGA-northeast of PGDP

farther than $3000 \mathrm{ft}$ from the site (plot 2$) \ldots \ldots \ldots \ldots \ldots \ldots \ldots \ldots \ldots \ldots \ldots \ldots \ldots \ldots .27$

9.34 Exit pathway ${ }^{99} \mathrm{Tc}$ results in the UCRS-northeast of PGDP

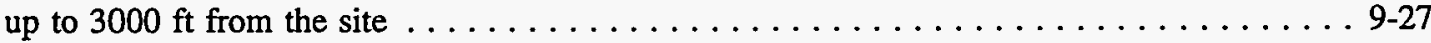

9.35 Exit pathway ${ }^{99} \mathrm{Tc}$ results in the RGA-northeast of PGDP

up to $3000 \mathrm{ft}$ from the site $\ldots \ldots \ldots \ldots \ldots \ldots \ldots \ldots \ldots \ldots \ldots \ldots \ldots \ldots \ldots \ldots \ldots \ldots \ldots \ldots .27$

9.36 Exit pathway TCE results in the RGA-northeast of PGDP

up to $3000 \mathrm{ft}$ from the site $\ldots \ldots \ldots \ldots \ldots \ldots \ldots \ldots \ldots \ldots \ldots \ldots \ldots \ldots \ldots \ldots \ldots .28$

9.37 Exit pathway ${ }^{99} \mathrm{Tc}$ results in the UCRS-northeast corner

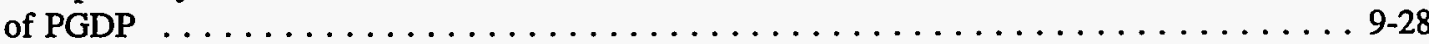

9.38 Exit pathway TCE results in the UCRS-northeast corner

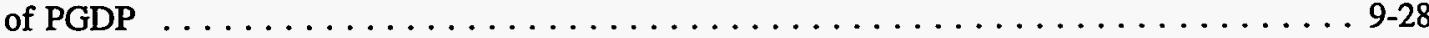

9.39 Exit pathway ${ }^{99} \mathrm{Tc}$ results in the RGA-northeast corner

of PGDP . . . . . . . . . . . . . . . . . . . . . . . . . . 9-29

9.40 Exit pathway TCE results in the RGA-northeast corner

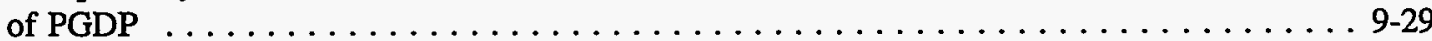

9.41 Exit pathway ${ }^{99} \mathrm{Tc}$ results in the UCRS-north central

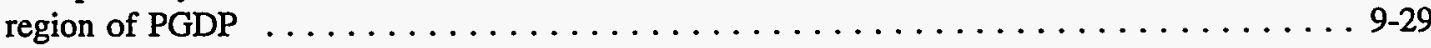

9.42 Exit pathway TCE results in the UCRS-north central

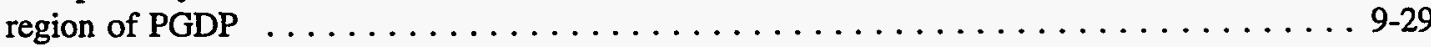

9.43 Exit pathway ${ }^{99} \mathrm{Tc}$ results in the RGA-north central

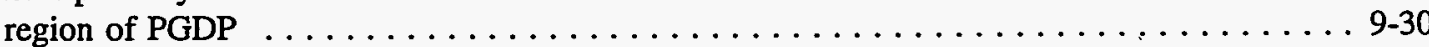


9.44 Exit pathway TCE results in the RGA-north central

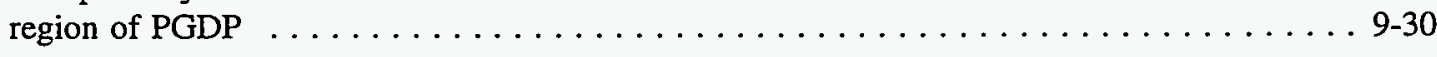

9.45 Exit pathway ${ }^{99} \mathrm{Tc}$ results in the UCRS-northwest of PGDP

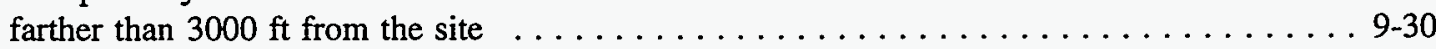

9.46 Exit pathway ${ }^{99} \mathrm{Tc}$ results in the RGA-northwest of PGDP

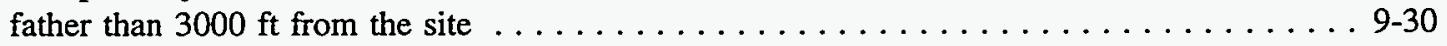

9.47 Exit pathway TCE results in the RGA-northwest of PGDP

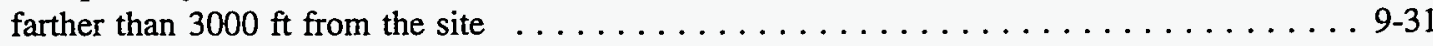

9.48 Exit pathway ${ }^{99} \mathrm{Tc}$ results in the UCRS-northwest of PGDP

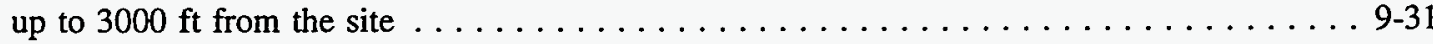

9.49 Exit pathway TCE results in the UCRS-northwest of PGDP

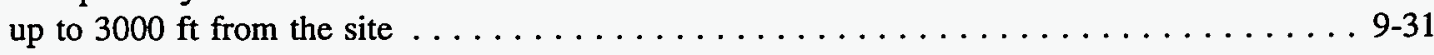

9.50 Exit pathway ${ }^{99} \mathrm{Tc}$ results in the RGA-northwest of PGDP up to $3000 \mathrm{ft}$ from the site $\ldots \ldots \ldots \ldots \ldots \ldots \ldots \ldots \ldots \ldots \ldots \ldots \ldots \ldots \ldots \ldots \ldots \ldots \ldots \ldots .32$

9.51 Exit pathway TCE results in the RGA-northwest of PGDP up to $3000 \mathrm{ft}$ from the site $\ldots \ldots \ldots \ldots \ldots \ldots \ldots \ldots \ldots \ldots \ldots \ldots \ldots \ldots \ldots \ldots \ldots .32$

9.52 Exit pathway ${ }^{99} \mathrm{Tc}$ results in the UCRS-northwest corner of PGDP $\ldots \ldots \ldots \ldots \ldots$ 9-32

9.53 Exit pathway ${ }^{99} \mathrm{Tc}$ results in the RGA-northwest corner of PGDP $\ldots \ldots \ldots \ldots \ldots . . \ldots 92$

9.54 Exit pathway ${ }^{99} \mathrm{Tc}$ results in the UCRS-west side of PGDP $\ldots \ldots \ldots \ldots \ldots \ldots \ldots$ 9-33

9.55 Exit pathway TCE results in the UCRS—west side of PGDP $\ldots \ldots \ldots \ldots \ldots \ldots \ldots .9-33$

9.56 Exit pathway ${ }^{99} \mathrm{Tc}$ results in the $\mathrm{RGA}$-west side of PGDP $\ldots \ldots \ldots \ldots \ldots \ldots \ldots$

9.57 Exit pathway TCE results in the RGA-west side of PGDP $\ldots \ldots \ldots \ldots \ldots \ldots \ldots \ldots$

9.58 Exit pathway ${ }^{99} \mathrm{Tc}$ results in the UCRS—southwest corner off-site $\ldots \ldots \ldots \ldots \ldots \ldots 9-34$

10.1 Environmental Monitoring Department organization chart $\ldots \ldots \ldots \ldots \ldots \ldots \ldots \ldots$ 10-2

A.1 Isotopes of the element hydrogen $\ldots \ldots \ldots \ldots \ldots \ldots \ldots \ldots \ldots \ldots \ldots \ldots \ldots \ldots \ldots \ldots \ldots$

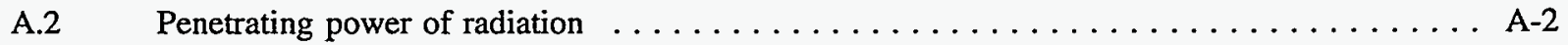

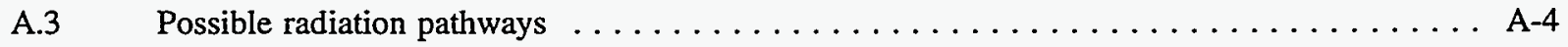




\section{List of Tables}

Table

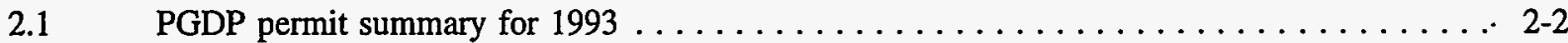

2.2 Occurrences reported to the National Response Center and

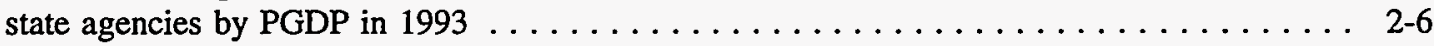

$2.3 \quad$ NEPA documentation for CY $1993 \ldots \ldots \ldots \ldots \ldots \ldots \ldots \ldots$

$2.4 \quad$ Large, high-voltage PCB capacitors at PGDP in $1993 \ldots \ldots \ldots \ldots \ldots$

2.5 Summary of PCB and PCB items in service as of December $31,1993 \ldots \ldots \ldots$

$2.6 \quad$ Environmental assessments at PGDP in $1993 \ldots \ldots \ldots \ldots \ldots$

4.1 Collection and radiological monitoring frequencies of surface water in 1993 (excluding KPDES) . . . . . . . . . . . . . . . . . . . . . . 4-5

$4.2 \quad$ Radionuclide concentrations in effluents for 1993 (Uranium) . . . . . . . . . . . . . . . 4-7

$4.3 \quad$ Radionuclide concentrations in effluents for $1993\left({ }^{99} \mathrm{Tc}\right) \ldots \ldots \ldots$

$5.1 \quad$ PGDP environmental air sampling for radioactivity in $1993 \ldots \ldots \ldots$

$5.2 \quad$ Maximum potential external gamma exposure rates at PGDP for $1993 \ldots \ldots$

5.3 Quality control data for external gamma exposure at PGDP for $1993 \ldots \ldots$

5.4 Collection and analysis frequencies of surface water samples at PGDP for $1993 \ldots \ldots \ldots \ldots \ldots \ldots \ldots \ldots \ldots \ldots \ldots \ldots \ldots \ldots \ldots$

5.5 Collection and analysis frequencies of soil and sediment samples

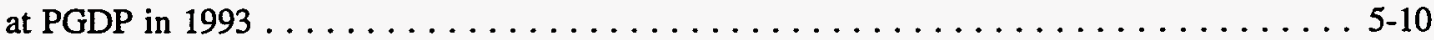

5.6 Radionuclide sediment data for PGDP in $1993 \ldots \ldots \ldots \ldots \ldots$

$5.7 \quad$ Uranium concentrations (in $\mu \mathrm{g} / \mathrm{g}$ ) in soil at PGDP, $1987-1993 \ldots \ldots \ldots$

$5.8 \quad$ Analysis results of annual food crop sampling near PGDP for $1993 \ldots \ldots$

$5.9 \quad$ PGDP 1993 annual deer harvest-analysis of liver tissue for radionuclides $\ldots \ldots \ldots$

5.10 PGDP 1993 annual deer harvest -analysis of muscle tissue for radionuclides . . . . . . . 5-15

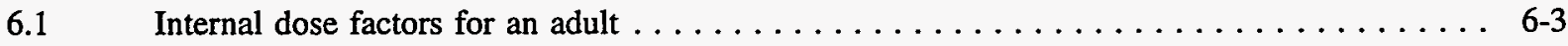

6.2 Summary of potential radiological dose for 1993 from PGDP . . . . . . . . . . . 6-6

KPDES outfalls at PGDP $\ldots \ldots \ldots \ldots \ldots \ldots \ldots \ldots \ldots$

7.2 Collection and analysis frequencies of surface

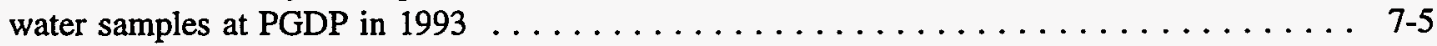


8.1 Environmental air sampling for fluorides at PGDP in $1993 \ldots \ldots \ldots \ldots \ldots \ldots$. $\ldots \ldots$.

8.2 Collection and analysis frequencies of surface water samples at PGDP in 1993

8.3 Collection and analysis frequencies of soil and sediment samples at PGDP for 1993

8.4 PCB results (in $\mu \mathrm{g} / \mathrm{g}$ ) for sediment samples from

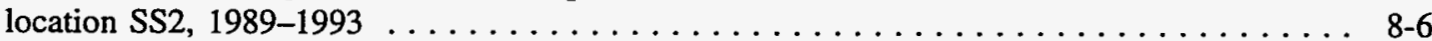

8.5 Fluoride in grass (dry weight) at PGDP for $1993 \ldots \ldots \ldots \ldots \ldots \ldots \ldots \ldots$

8.6 Mercury in fish-West Kentucky Wildlife Management Area comparisons $\ldots \ldots \ldots .8-10$

8.7 PGDP 1993 annual deer harvest-analysis of liver tissue

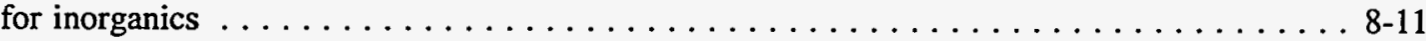

8.8 PGDP 1993 annual deer harvest-analysis of muscle tissue

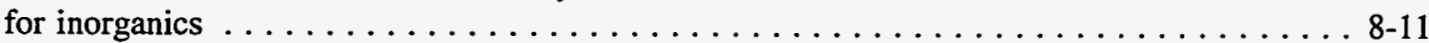

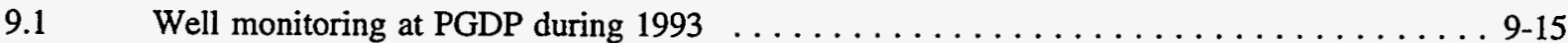

9.2 PGDP WAGs scheduled for action in the near future $\ldots \ldots \ldots \ldots \ldots \ldots \ldots \ldots . \ldots .19$

A.1 Comparison and description of various dose levels $\ldots \ldots \ldots \ldots \ldots \ldots \ldots \ldots \ldots$

B.1 Superfund Amendments and Reauthorization Act, Title III, Section 313, chemical release information for $1993 \ldots \ldots \ldots \ldots \ldots \ldots \ldots \ldots \ldots$. . 1

B.2 Superfund Amendments and Reauthorization Act, Section 312,

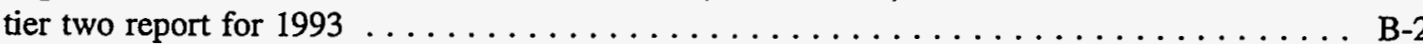




\section{Acronyms and Abbreviations}

\begin{tabular}{|c|c|}
\hline $\mathrm{ACO}$ & Administrative Consent Order \\
\hline $\mathrm{ADI}$ & acceptable daily intake \\
\hline AEC & Atomic Energy Commission \\
\hline AIP & agreement in principle \\
\hline ALARA & as low as reasonably achievable \\
\hline ANSI & American National Ståndards Institute \\
\hline APG & Analytical Products Group, Inc. \\
\hline Av & average \\
\hline $\mathrm{BE}$ & boundary east \\
\hline BMP & Biological Monitoring Program \\
\hline $\mathrm{BN}$ & boundary north \\
\hline $\mathrm{Bq}$ & becquerel \\
\hline BTU & British thermal unit \\
\hline CAA & Clean Air Act \\
\hline CEDE & committed effective dose equivalent \\
\hline CEQ & Council on Environmental Quality \\
\hline CERCLA & Comprehensive Environmental Response, Compensation, and Liability Act \\
\hline CFC & chlorofluorocarbon \\
\hline CFR & Code of Federal Regulations \\
\hline CHR & Cabinet for Human Resources \\
\hline $\mathrm{cm}$ & centimeter \\
\hline $\mathrm{CO}$ & carbon monoxide \\
\hline $\mathrm{COE}$ & Corps of Engineers \\
\hline CSTP & conceptual site treatment plan \\
\hline CWA & Clean Water Act \\
\hline $\mathrm{CX}$ & categorical exclusion \\
\hline $\mathrm{CY}$ & calendar year \\
\hline DCG & derived concentration guideline \\
\hline DES & Kentucky Disaster and Emergency Services \\
\hline DMR & Discharge Monitoring Report \\
\hline DNAPL & dense nonaqueous phase liquid \\
\hline DOE & U.S. Department of Energy \\
\hline DOE-ORO & U.S. Department of Energy Oak Ridge Operations \\
\hline DOT & U.S. Department of Transportation \\
\hline DSTP & draft site treatment plan \\
\hline EA & environmental assessment \\
\hline EAD & environmental assessment determination \\
\hline EDE & effective dose equivalent \\
\hline EIMS & Environmental Information Management System \\
\hline EIS & environmental impact statement \\
\hline EMD & Environmental Monitoring Department \\
\hline EML & Environmental Measurements Laboratory \\
\hline EMP & 1. Environmental Monitoring Plan \\
\hline & 2. environmental monitoring program \\
\hline EPA & U.S. Environmental Protection Agency \\
\hline EPCRA & Emergency Planning and Community Right-To-Know Act \\
\hline ER & environmental restoration \\
\hline ERWM & Environmental Restoration and Waste Management \\
\hline
\end{tabular}




\begin{tabular}{|c|c|}
\hline $\begin{array}{l}\text { ES\&H } \\
\text { ESP }\end{array}$ & $\begin{array}{l}\text { Environmental, Safety, and Health } \\
\text { electrostatic precipitator }\end{array}$ \\
\hline${ }^{\circ} \mathrm{F}$ & degrees Fahrenheit \\
\hline F. col. & fecal coliform \\
\hline FDA & Food and Drug Administration \\
\hline FFA & federal facilities agreement \\
\hline FFCA & federal facilities compliance agreement \\
\hline FFCAct & Federal Facilities Compliance Act \\
\hline FIFRA & Federal Insecticide, Fungicide, and Rodenticide Act \\
\hline FS & feasibility study \\
\hline FSAR & facility safety analysis report \\
\hline $\mathrm{ft}$ & foot \\
\hline FY & fiscal year \\
\hline $\mathrm{g}$ & gram \\
\hline GR & Grahamville \\
\hline GWPP & Groundwater Protection Program Plan \\
\hline ha & hectares \\
\hline HARM & Hazardous Atmospheric Release Model \\
\hline HEPA & high-efficiency particulate air \\
\hline $\mathrm{HF}$ & hydrogen fluoride \\
\hline HSWA & Hazardous Solid Waste Amendments \\
\hline ICP & inductively coupled plasma \\
\hline ICRP & International Commission on Radiological Protection \\
\hline in. & inch \\
\hline KDAQ & Kentucky Division for Air Quality \\
\hline KDEP & Kentucky Department for Environmental Protection \\
\hline KDOW & Kentucky Division of Water \\
\hline KDWM & Kentucky Division of Waste Management \\
\hline $\mathrm{km}$ & kilometer \\
\hline $\mathrm{KOH}$ & potassium hydroxide \\
\hline KPDES & Kentucky Pollutant Discharge Elimination System \\
\hline lb & pound \\
\hline LCR & lowest concentration reported \\
\hline LDR & land disposal restriction \\
\hline LLD & lower limit of detection \\
\hline LLW & low-level waste \\
\hline $\mathrm{m}$ & meter \\
\hline $\mathrm{m}^{2}$ & square meter \\
\hline $\mathrm{m}^{3}$ & cubic meter \\
\hline MACT & Maximum Achievable Control Technology \\
\hline Max & maximum \\
\hline $\mathrm{MCL}$ & maximum contaminant \\
\hline MDL & minimum detection level \\
\hline$\mu \mathrm{Ci}$ & microcurie \\
\hline$\mu \mathrm{g}$ & microgram \\
\hline$\mu \mathrm{R}$ & microrad \\
\hline Min & minimum \\
\hline $\mathrm{mL}$ & milliliter \\
\hline
\end{tabular}


$\mathrm{mm}$

MMES

MIMUS

MOU

mrem

MSDS

$\mathrm{mSv}$

MW

MWIR

NCP

NEPA

NESHAP

NHPA

NIOSH

NIST

NOV

NPDES

NPL

NRC

ORNL

ORO

PAT

PCB

$\mathrm{pCi}$

PE

PEC

PET

PGDP

$\mathrm{PM}_{10}$

PN

ppb

ppm

PW

QA

QC

RCRA

$\mathrm{RCW}$

RfD

RFI

RGA

RI/FS

RUs

SARA

SDWA

SMP

SWMU millimeter

Martin Marietta Energy Systems, Inc.

Martin Marietta Utility Services, Inc.

memorandum of understanding

millirem

material safety data sheet

millisievert

monitoring well

mixed waste inventory report

National Contingency Plan

National Environmental Policy Act

National Emission Standards for Hazardous Air Pollutants

National Historic Preservation Act

National Institute for Occupational Safety and Health

National Institute of Standards and Technology

notice of violation

National Pollutant Discharge Elimination System

National Priorities List

Nuclear Regulatory Commission

Oak Ridge National Laboratory

Oak Ridge Operations

Proficiency Analytical Testing

polychlorinated biphenyl

picocurie

plant east

Performance Evaluation Committee

Proficiency Environmental Testing

Paducah Gaseous Diffusion Plant

particulate matter less than 10 microns in diameter

plant north

part per billion

part per million

plant west

quality assurance

quality control

Resource Conservation and Recovery Act

recirculating cooling water

reference dose

RCRA facility investigation

regional gravel aquifer

remedial investigation/feasibility study

requirement units

Superfund Amendments and Reauthorization Act

Safe Drinking Water Act

Site Management Plan

solid waste management unit 
Tc

TCA

TCE

TCLP

TDS

TLD

TOC

TSCA

TSS

TVA

UCRS

$\mathrm{UF}_{6}$

USEC

USFWA

USGS

UST

VOC

WAG

WKWMA

WMPP technetium

trichloroethane

trichloroethylene

Toxicity Characteristic Leachate Procedure

total dissolved solids

thermoluminescent dosimeter

total organic carbon

Toxic Substances Control Act

total suspended solids

Tennessee Valley Authority

upper continental recharge system

uranium hexafluoride

United States Enrichment Corporation

U.S. Fish and Wildlife Service

U.S. Geological Survey

underground storage tank

volatile organic compound

waste area grouping

West Kentucky Wildlife Management Area waste minimization/pollution prevention 


\title{
1. Site and Operations Overview
}

Vicki W. Jones

\begin{abstract}
Paducah Gaseous Diffusion Plant (PGDP), located in McCracken County, Kentucky, has been producing enriched uranium since 1952. In July 1993, the U.S. Department of Energy (DOE) leased the production areas of the site to the United States Enrichment Corporation (USEC). A new Martin Marietta Corporation subsidiary, Martin Marietta Utility Services, Inc., operates the leased facilities for the USEC. DOE maintains responsibility for the environmental restoration and waste management activities at the plant through its operating contractor, Martin Marietta Energy Systems, Inc. The purpose of this document is to summarize calendar year 1993 environmental monitoring activities at PGDP. DOE requires all of its facilities to conduct and document such activities annually.
\end{abstract}

The purpose of this document is to summarize effluent monitoring and environmental surveillance results and compliance with environmental laws, regulations, and orders at the Paducah Gaseous Diffusion Plant (PGDP). The U.S. Department of Energy (DOE) owns PGDP and requires that environmental monitoring be conducted and documented for all of its facilities under the purview of DOE Order 5400.1.

Environmental monitoring at PGDP consists of two major activities: effluent monitoring and environmental surveillance. Effluent monitoring is direct measurement or the collection and analysis of samples of liquid and gaseous discharges to the environment. Environmental surveillance is direct measurement or the collection and analysis of samples of air, water, soil, foodstuff, biota, and other media. Environmental monitoring is performed to characterize and quantify contaminants, assess radiation exposures of members of the public, demonstrate compliance with applicable standards and permit requirements, and detect and assess the effects (if any) on the local environment. Multiple samples are collected throughout the year and are analyzed for radioactivity, chemical content, and various physical attributes.

The PGDP overall goal for environmental management is to protect the environment and PGDP's neighbors and to maintain full compliance with all current regulations. The current environmental strategy is to identify any deficiencies and develop a system to resolve them. The long-range goal of environmental management is to minimize the source of pollutants, reduce the generation of waste, and minimize hazardous waste by substitution of materials.

\section{INTRODUCTION}

Before World War II, the area now occupied by PGDP was used for agricultural purposes. Numerous small farms produced various grain crops and provided pasture for livestock. Early in the war, a 6526-ha (16,126-acre) tract was assembled for construction of the Kentucky Ordnance Works, which was subsequently operated by the Atlas Powder Company until the end of the war when it was turned over to the Federal Farm Mortgage Corporation and then to the General Services Administration.

In 1950, the Department of Defense and DOE's predecessor, the Atomic Energy Commission (AEC), began efforts to expand fissionable material production capacity. As part of this effort, the National Security Resources Board was instructed to designate power areas within the strategically safe area of the United States. Eight government-owned sites were initially selected as candidate areas, one of which was the Kentucky Ordnance Works site. In October 1950, as a result of joint recommendations from the Department of Defense, Department of State, and the AEC, President Truman directed the AEC to further expand production of atomic weapons. One of the principal facets of this expansion program was the provision for a new gaseous diffusion plant. On October 18, 1950, the AEC approved the Paducah site for uranium enrichment operations and formally requested the Department of the Army to transfer the site from the General Services Administration to the AEC.

Construction of PGDP was completed in 1954, although production began in 1952. The plant's mission, uranium enrichment, has continued unchanged, and the original facilities are still in operation, albeit with substantial upgrading and refurbishment. Of the 3062 ha (7566 acres) acquired by the AEC, 551 ha (1361 acres) was subsequently transferred to the Tennessee Valley Authority (Shawnee Steam Plant site), and 1125 ha 
(2781 acres) was conveyed to the commonwealth of Kentucky for use in wildlife conservation and for recreational purposes. Thus, DOE's current holdings are 1386 ha (3423 acres).

In October 1992, Congressional passage of the Energy Policy Act established the United States Enrichment Corporation (USEC). Effective July 1, 1993, DOE leased the plant production operations facilities to USEC. Martin Marietta Corporation created Martin Marietta Utility Services, Inc. (a new subsidiary), to operate the leased facilities for USEC under the prior operating contract. Under the terms of the lease, USEC has assumed responsibility for compliance activities directly associated with uranium enrichment operations. DOE has retained responsibility for the site Environmental Restoration Program; the bulk of the Waste Management Program, including waste inventories predating July 1, 1993; wastes generated by current DOE activities; wastes containing "legacy" constituents, such as asbestos, polychlorinated biphenyls, and transuranics; and Kentucky Pollutant Discharge Elimination System compliance at outfalls not leased to USEC. DOE has also retained manager and co-operator status of facilities not leased to USEC. DOE and USEC have negotiated the lease of specific plant site facilities, written memorandums of agreement to define their respective roles and responsibilities under the lease, and developed organizations and budgets to support their respective functions.

\section{DESCRIPTION OF SITE LOCALE}

\section{Location}

PGDP is located in a generally rural area of McCracken County, Kentucky. The plant is about $16 \mathrm{~km}$ (10 miles) west of Paducah, Kentucky, and $4.8 \mathrm{~km}$ ( 3 miles) south of the Ohio River (see Figs. 1.1 and 1.2). About 304 ha (750 acres) are contained within the security fence where the cascade buildings (containing the uranium enrichment process equipment) and ORNL-DWG 92M-5978 support facilities are located. An uninhabited buffer zone is provided by an extensive wildlife management area consisting of 850 ha (2100 acres) either deeded or leased to the commonwealth of Kentucky. The population within an 80-km (50-mile) radius of the plant is about 300,500 , of which about 39,500 are located within a $16-\mathrm{km}$ (10-mile) radius.

\section{Climate}

PGDP is located in the humid continental zone where summers are warm [July averages $26^{\circ} \mathrm{C}\left(79^{\circ} \mathrm{F}\right)$ ] and winters are moderately cold [January averages $1.7^{\circ} \mathrm{C}\left(35^{\circ} \mathrm{F}\right)$ ]. Yearly precipitation averages about $120 \mathrm{~cm}$ (47 in.); the prevailing wind is from the south-southwest.

\section{Water Resources}

PGDP is situated in the western part of the Ohio River basin. The confluence of the Ohio River with the Tennessee River is about $24 \mathrm{~km}$ (15 miles) upstream of the site, and the confluence of the Ohio River with the Mississippi River is about $90 \mathrm{~km}$ (35 miles) downstream. The plant is located on a local drainage divide; surface flow is east-northeast toward Little Bayou Creek and west-northwest toward Big Bayou Creek. Big Bayou Creek is a perennial stream that flows toward the river along a $14.5-\mathrm{km}$ (9-mile) course. Little Bayou Creek is an intermittent stream that flows north toward the Ohio River along a $10.5-\mathrm{km}$ (6.5-mile) course. The two creeks converge $4.8 \mathrm{~km}$ ( 3 miles) north of the plant. 


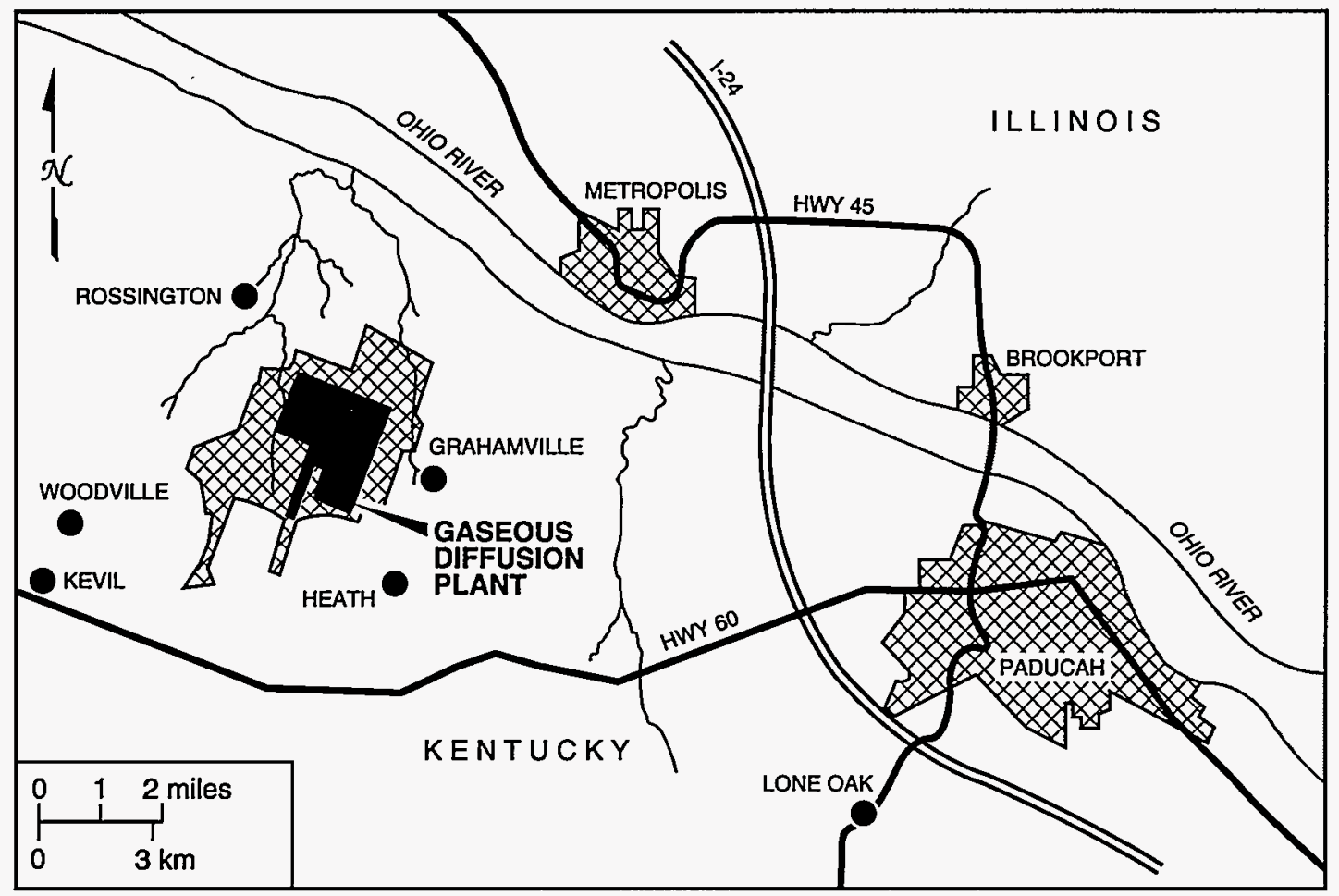

Fig. 1.2. Location of PGDP in relationship to the geographic region.

\section{Geology and Hydrology}

Soils of the area are predominantly silt loams that are poorly drained, acidic, and have little organic content. The regional gravel aquifer is the uppermost aquifer underlying most of PGDP and the contiguous area north. This groundwater flow system is developed primarily in Pleistocene sands and gravels of the lower member of the Continental Deposits, occurring between 13 and $33 \mathrm{~m}$ (43 and $100 \mathrm{ft}$ ) beneath the plant. The upper member of the Continental Deposits is predominantly composed of silt and clay with interbedded sand and gravel lenses. A layer of loess 3 to $10 \mathrm{~m}$ (10 to $30 \mathrm{ft}$ ) thick overlies the Continental Deposits at the surface. The Continental Deposits rest on terraces cut by the ancestral Tennessee and Tennessee-Ohio rivers. Within the regional gravel aquifer, flow is directed north, discharging into the Ohio River.

\section{ECOLOGICAL RESOURCES}

\section{Vegetation}

The PGDP reservation is a highly disturbed area. Vegetation communities on the reservation are indicative of old field succession (i.e., grassy fields, field scrub-shrub, and upland mixed hardwoods).

The open grassland areas, managed by West Kentucky Wildlife Management Area personnel, are periodically mowed or burned to maintain early successional vegetation, which is dominated by members of the composite family and various grasses. Management practices on the Wildlife Management Area encourage reestablishment of once common native grasses such as eastern gama grass and Indian grass. Other species commonly cultivated for wildlife forage are corn, millet, milo, and soybean (CH2M Hill 1991a).

Field scrub-shrub communities consist of sun-tolerant wooded species such as persimmon, maples, black locust, sumac, scattered oaks, and mixed hardwood species (CH2M Hill 1991a). The undergrowth may vary depending on the location of the woodlands. Wooded areas near maintained grasslands may have an undergrowth dominated by grasses; other communities may contain a thick undergrowth of shrubs, including sumac, pokeweed, honeysuckle, blackberry, and grape. 
Upland mixed hardwoods contain a variety of upland and transitional species. Dominant species include oaks, shagbark and shellbark hickory, and sugarberry (CH2M Hill 1991a). Undergrowth may vary from open, with limited vegetation for more mature stands of trees, to dense undergrowth similar to that described for a scrub-shrub community.

\section{Wildlife}

Wildlife species indigenous to hardwood forests and open grassland communities occur in the vicinity of PGDP. Grassy fields are frequented by rabbits, mice, songbirds, and a variety of other small mammals and birds. Red-winged blackbirds, killdeer, cardinals, mourning doves, bobwhite quail, meadowlarks, warblers, sparrows, and red-tail hawks have been observed in such areas. Shrub-scrub communities support a variety of wildlife, including opossums, voles, moles, raccoons, gray squirrels, killdeer, bluejays, red-winged blackbirds, bluebirds, cardinals, mourning doves, shrike, warblers, turkeys, and meadowlarks. Deer, squirrels, raccoons, turkeys, songbirds, and great horned owls are found within the mature woodlands of PGDP (CH2M Hill 1991a).

The Ohio River serves a major flyway for migratory birds (SAIC 1992). Migratory birds and transient residents are occasionally seen on the DOE reservation.

Amphibians and reptiles are common throughout the area surrounding PGDP. Amphibians likely to inhabit the area include the American and Woodhouse's toad. Reptiles include the eastern box turtle and several species of snakes (SAIC 1992).

\section{DESCRIPTION OF SITE OPERATIONS AND FACILITIES}

The USEC, through its operating contractor, Martin Marietta Utility Services, Inc., operates production aspects of PGDP.

The gaseous diffusion enrichment process uses the uranium hexafluoride $\left(\mathrm{UF}_{6}\right)$ form of uranium, which is a white, crystalline solid at ambient conditions and a gas at process conditions. The enrichment method increases ${ }^{235} \mathrm{U}$ concentrations by physical processes; the $\mathrm{UF}_{6}$ gas is not altered chemically.

The gaseous diffusion process employs a series of compressors and converters to enrich the ${ }^{235} \mathrm{U}$ isotope of the process gas. The fundamental building block of the process consists of a compressor and a converter and is known as a stage. Stages are grouped together in series to form cells. The cells are then interconnected to provide what is known as a cascade. The compressors, which are driven by electric motors, are used to circulate the process gas and maintain flow through the cascade. The converters contain porous tubes or barriers through which the process gas is diffused. In each converter, a portion of the process gas diffuses through the barrier and is fed to the next higher stage, with the undiffused gas recycled to the next lower stage. The diffused stream is slightly enriched with respect to ${ }^{235} \mathrm{U}$, while the undiffused stream is depleted of ${ }^{235} \mathrm{U}$ to the same degree. Each stage also contains a gas cooler to remove the heat of compression from the process gas and a control valve for process control (see Fig. 1.3, which depicts a typical stage arrangement at the junction of two cells). The output of PGDP is now one of the feed streams to the Portsmouth Gaseous Diffusion Plant.

DOE, through its operating contractor, Martin Marietta Energy Systems, Inc., operates the Environmental Restoration and Waste Management programs at the plant. The Environmental Restoration staff performs remedial investigations to define the nature and extent of contamination, evaluates the risks to public health and the environment, and determines the available alternatives for a feasibility study of potential remedial actions for sites under investigation. The goal of the Environmental Restoration Program is to ensure that releases from past operations and waste management at PGDP are thoroughly investigated and that appropriate remedial action is taken for the protection of human health and the environment. 
ORNL-DWG 94M-7193

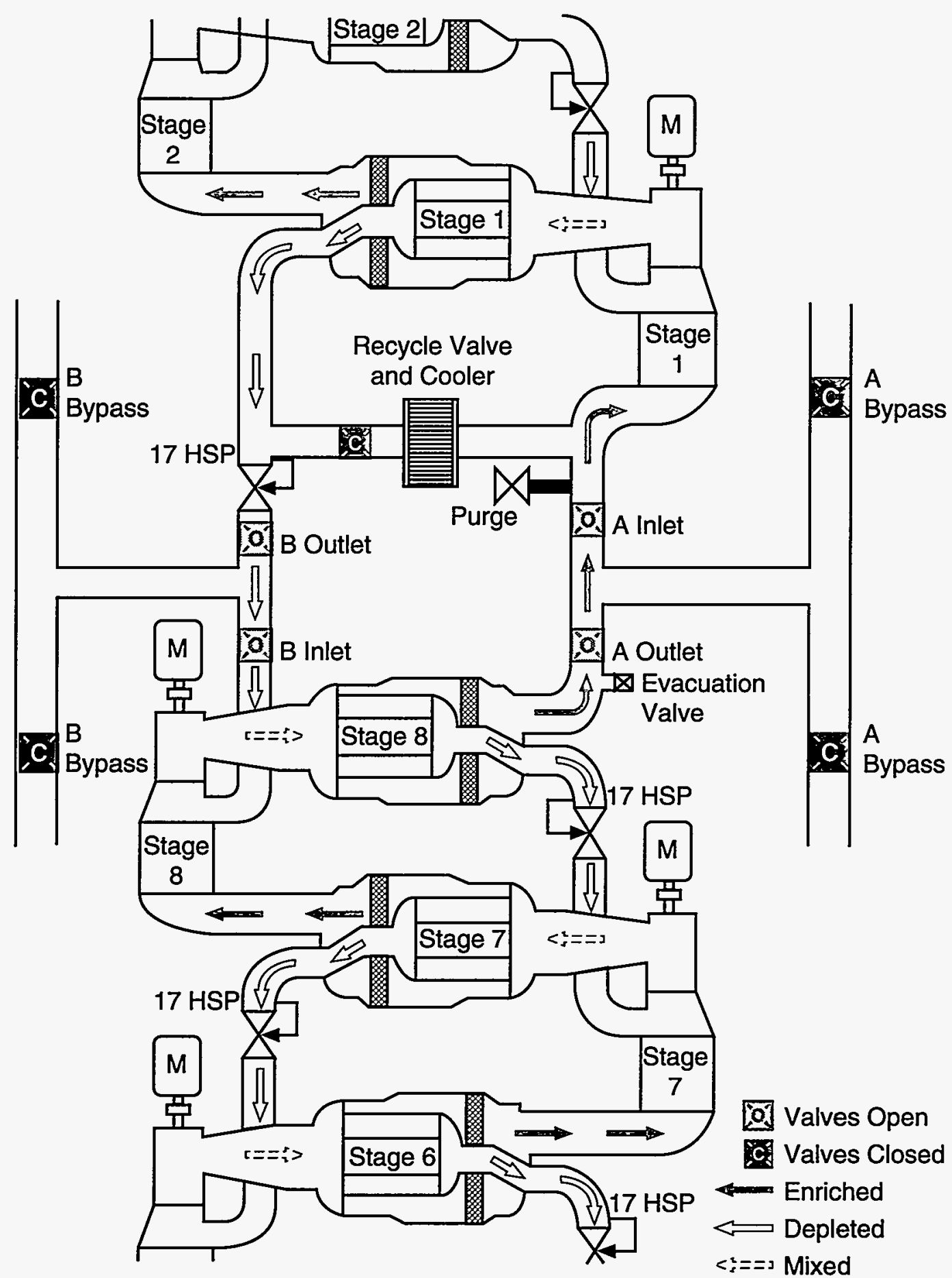

Fig. 1.3. Typical stage arrangement at the junction of two cells in the gaseous diffusion process for enriching uranium. 


\title{
2. Environmental Compliance
}

\author{
S. K. Bowe, B. A. Bowers, T. L. Feldhaus, R. L. Fields, D. W. Jones, V. W. Jones, K. E. Krahl, \\ S. M. Leone, J. Morgan, J. W. Rinella, S. Shidal, R. C. Summers, and C. C. Travis
}

\section{Abstract}

The policy of the Paducah Gaseous Diffusion Plant and the U.S. Department of Energy is to conduct operations safely and minimize the impact of operations on the environment. Protection of the public, environment, and employees is considered a responsibility of paramount importance.

\section{INTRODUCTION}

Paducah Gaseous Diffusion Plant (PGDP) is owned by the U.S. Department of Energy (DOE). In October 1992, Congressional passage of the Energy Policy Act established the United States Enrichment Corporation (USEC). Effective July 1, 1993, DOE leased the plant production operations facilities to USEC. Martin Marietta Corporation created Martin Marietta Utility Services, Inc. (MMUS), a new subsidiary, to operate the leased facilities for USEC under the prior operating contract. Under the terms of the lease, USEC has assumed responsibility for compliance activities directly associated with uranium enrichment operations. DOE has retained responsibility for the site Environmental Restoration Program; the bulk of the Waste Management Program, including waste inventories predating July 1, 1993; wastes generated by current DOE activities; wastes containing "legacy" constituents, such as asbestos, polychlorinated biphenyls (PCBs), and transuranics; and Kentucky Pollutant Discharge Elimination System (KPDES) compliance at outfalls not leased to USEC. DOE has also retained manager and co-operator status of Resource Conservation and Recovery Act (RCRA) storage facilities not leased to USEC. DOE and USEC have negotiated the lease of specific plant site facilities, prepared memorandums of agreement to define their respective roles and responsibilities under the lease, and developed organizations and budgets to support their respective functions.

Local, state, and DOE and other federal agencies are responsible for enforcing environmental regulations at PGDP facilities. Principal among other regulating agencies are the U.S. Environmental Protection Agency (EPA) Region IV and the Kentucky Department for Environmental Protection (KDEP). These agencies issue permits, review compliance reports, participate in joint monitoring programs, inspect facilities and operations, and oversee compliance with applicable regulations.

The EPA develops, promulgates, and enforces environmental protection regulations and technology-based standards as directed by statutes passed by the U.S. Congress. In some instances, the EPA has delegated regulatory authority to the KDEP when the Kentucky program meets or exceeds EPA requirements. Where regulatory authority is not delegated, EPA Region IV is responsible for reviewing and evaluating compliance with EPA regulations as they pertain to PGDP. Table 2.1 is a summary of PGDP permits.

\section{COMPLIANCE ACTIVITIES}

\section{RCRA}

RCRA regulates identification, treatment, storage, and disposal of hazardous waste. Waste generators must follow specific requirements outlined in RCRA for handling hazardous wastes. Owners and operators of hazardous waste management facilities are required to obtain operating and closure permits for hazardous waste management activities.

PGDP generates and manages both hazardous wastes and mixed wastes (i.e., hazardous wastes mixed with radionuclides). Hazardous and mixed wastes are accumulated by individual generators at several satellite accumulation areas, or 90-day areas, where they are managed by waste management personnel. Waste management personnel receive the waste and place it in on-site permitted storage facilities until it can be shipped off-site for treatment, storage, and/or disposal at RCRA-permitted facilities. PGDP submits annual documents detailing the facility's hazardous waste activities to the commonwealth of Kentucky, Division of Waste Management, by March 1 of each year. 
Table 2.1. PGDP permit summary for 1993

\begin{tabular}{|c|c|c|c|}
\hline Permit type & Issuer & $\begin{array}{l}\text { Expiration } \\
\text { date }\end{array}$ & Permit No. \\
\hline $\begin{array}{l}\text { Kentucky Pollutant Discharge Elimination } \\
\text { System }\end{array}$ & $\begin{array}{l}\text { Kentucky Division of } \\
\text { Water }\end{array}$ & $10 / 31 / 1997$ & KY0004049 \\
\hline $\begin{array}{l}\text { RCRA Hazardous Waste Management } \\
\text { Permit }\end{array}$ & $\begin{array}{l}\text { Kentucky Division of } \\
\text { Waste Management }\end{array}$ & $8 / 19 / 2001$ & KY8890008982 \\
\hline RCRA Part B post-closure & $\begin{array}{l}\text { Kentucky Division of } \\
\text { Waste Management }\end{array}$ & $\mathrm{NA}^{a}$ & KY/H35, Rev. 1 \\
\hline Residential landfill & $\begin{array}{l}\text { Kentucky Division of } \\
\text { Waste Management }\end{array}$ & Pending & 073.14 \\
\hline Inert landfill & $\begin{array}{l}\text { Kentucky Division of } \\
\text { Waste Management }\end{array}$ & Pending & 073.15 \\
\hline Air Operating Permit & $\begin{array}{l}\text { Kentucky Division for } \\
\text { Air Quality }\end{array}$ & None & $0-85-110$ \\
\hline $\begin{array}{l}\text { Permit-by-rule (applies to the following) } \\
\text { C- } 616 \text { chromium reduction facility } \\
\text { C-400-D line precipitation unit } \\
\text { C-403 neutralization pit } \\
\text { Clean metal scrap yard } \\
\text { Waste treatment lagoons at C-611 } \\
\text { Liquid pollution abatement lagoons } \\
\text { at C-616 } \\
\text { C-410-C neutralization pit } \\
\text { Regulated scrap metal yard }\end{array}$ & NA & NA & NA \\
\hline
\end{tabular}

Not applicable.

PGDP hazardous waste facilities are operated under a 10 -year hazardous waste management permit (No. KY8-890-008-982) issued by the commonwealth of Kentucky on August 19, 1991. In June 1993, the KDEP modified the permit to include the USEC as a co-operator. This permit authorizes PGDP to treat and store hazardous wastes in 10 treatment units, 16 tanks, and 4 container storage areas at the facility. Closure was initiated for the C-720 trichloroethylene (TCE) degreaser unit in 1992. Final closure of this unit is progressing and is anticipated in 1994. Work on a modification to the hazardous waste management permit was initiated in 1993 for closure of the C-400-C nickel stripper unit and the C-409 pilot plant unit, as well as the addition of a new container storage area (C-752-A). Submission of the modification is anticipated for the first quarter of 1994. Closure of these units will leave only one treatment facility (C-400-D), consisting of one tank and a rotary vacuum filter. All container storage areas will remain operational.

On July 15, 1991, the EPA and the commonwealth of Kentucky jointly issued a RCRA permit to DOE. The RCRA permit consists of two individual permits, a hazardous waste permit administered by the commonwealth of Kentucky and a hazardous solid waste amendment (HSWA) permit administered by the EPA. The EPA HSWA permit addresses only the provisions of HSWA, which include corrective actions for solid waste management units. The hazardous waste permit issued by the commonwealth of Kentucky contains regulatory provisions for treatment, storage, and disposal activities authorized under the RCRA base program (pre-HSWA), as well as the HSWA provisions. Although the EPA has authorized the commonwealth of Kentucky to exclusively administer the RCRA base program for treatment, storage, and disposal units (pre-HSWA), Kentucky has not received authorization to administer the HSWA provisions in lieu of EPA provisions, which has resulted in dual requirements for corrective actions under state and federal laws.

The schedule of compliance in the RCRA permit requires DOE to develop and implement a RCRA facility investigation (RFI) work plan for solid waste management units and areas of concern. Through January 1994, DOE has submitted four RFI work plans to the EPA and the Kentucky Division of Waste Management (KDWM) 
in accordance with the time frames specified in the schedule of compliance. The RFI work plan for waste area groupings (WAGs) 1 and 7 has been approved and is being implemented. In addition, several RCRA interim corrective measures work plans have been submitted and approved and are being implemented.

\section{Land Disposal Restrictions (LDRs)}

Mixed (RCRA, radioactive) waste has been stored at PGDP. These wastes are subject to the LDR storage prohibition that permits storage only for accumulation of sufficient quantities to facilitate proper treatment, recycle, or disposal. Mixed wastes are being stored at PGDP because of a nationwide shortage of treatment and disposal facilities for these types of waste. Storage of waste for this purpose does not comply with LDR regulations. If not for the radioactive constituents, these wastes would not pose a compliance problem for PGDP. Consequently, on June 30, 1992, DOE entered into a federal facilities compliance agreement (FFCA) with EPA Region IV to regulate the treatment and storage of LDR mixed waste at PGDP.

\section{Notices of Violation (NOVs)}

The KDWM performed a compliance evaluation inspection in September 1993. The inspection resulted in an NOV citing alleged violations in procedural and administrative matters relating to the documentation of safety/emergency equipment inspections. Although all agency concerns were addressed expediently, a $\$ 5000$ penalty assessment for the NOV was received in January 1994.

\section{Superfund Amendments and Reauthorization Act (SARA)}

Table B.1 in Appendix B of this report contains the SARA, Title III, Section 313, chemicals reported for 1993. The SARA 313 chemicals are summarized from information being compiled for the SARA Title III, Section 313, report required by SARA. This report is submitted on July 1 of each year for the previous calendar year and contains chemicals on the EPA toxic substances list. More than 300 specific chemicals and 20 chemical categories must be reviewed and possibly reported under SARA 313. If any of these chemicals were manufactured in excess of $25,000 \mathrm{lb}$, processed in excess of $25,000 \mathrm{lb}$, or "otherwise used" in excess of $10,000 \mathrm{lb}$ at a facility during CY 1993, the chemical must be reported. In many instances, the estimate of quantities released was obtained through material balance calculations, monitoring data, or engineering calculations. In some cases no quantitative monitoring data, inventory estimates, or emission factors were readily available, and release estimates were based on "best engineering judgment." Information obtained from air permits, rates of operation, quantities used, and known treatment efficiencies were used to estimate quantities released to the environment. Typically, assumptions based on best engineering judgment were required to perform the calculations when all variables were not known.

Appendix B also contains the SARA 312 chemicals reported for CY 1993. This report contains the greatest amount of SARA chemicals stored on-site at any one time during the year. The 312 report is submitted on March 1 of each year for the previous calendar year.

\section{Comprehensive Environmental Response, Compensaťion, and Liability Act (CERCLA)}

The primary purpose of CERCLA is to protect human health and the environment through cleanup of unpermitted releases of hazardous substances. Specific CERCLA regulations applicable to the Environmental Restoration (ER) Program are commonly referred to as the National Contingency Plan. The plan outlines the procedural, substantive, and administrative requirements for responding to releases of hazardous substances.

In accordance with Section 120(d)(2) of CERCLA, the EPA evaluated PGDP using the hazard ranking system. PGDP was proposed for listing on the National Priorities List (NPL) in the Federal Register on May 10, 1993. Although PGDP has not yet been listed on the NPL, the site is subject to CERCLA requirements through an administrative consent order (ACO).

Section 120 of CERCLA requires federal facilities on the NPL to enter into a federal facilities agreement (FFA) with the appropriate regulatory agencies. Pursuant to Section 120 and the imminent listing of PGDP on the NPL, DOE has initiated negotiations with the EPA and the commonwealth of Kentucky to develop an FFA. 
The FFA will serve as the primary regulatory agreement for remediation activities at PGDP and will integrate CERCLA remedial action requirements with the RCRA corrective action requirements specified in the HSWA permit. The FFA is expected to be signed in 1994.

In July 1988, the Kentucky Radiation Control Branch, in conjunction with the Purchase District Health Department, sampled several residential groundwater wells north of PGDP in response to concerns from a local citizen regarding the quality of water in his private well. Subsequent analyses of these samples revealed elevated gross beta levels, indicative of possible radionuclide contamination. On August 9, 1988, these results were reported to PGDP, which responded by sampling several private groundwater wells around the site on August 10, 1988. Upon analysis, some of the samples collected contained elevated levels of both TCE and ${ }^{99} \mathrm{Tc}$. In response to the July 1988 finding by the Purchase District Health Department (which revealed that groundwater contamination potentially existed in a local residential well), PGDP immediately instituted the following response actions:

- provided bottled water to affected residences,

- sampled surrounding residential wells to assess the extent of contamination,

- extended the city water line to affected residences as a permanent source of water, and

- began routine sampling of residential wells around PGDP.

Following the initial response actions, in August 1988 DOE and the EPA entered into an ACO under Sections 104 and 106 of CERCLA. The major requirements of the ACO include monitoring of residential wells potentially affected by contamination, providing alternative drinking water supplies to residents with contaminated wells, and investigation of the nature and extent of off-site contamination. Pursuant to the ACO, DOE continued routine sampling of residential wells and initiated a two-phase site investigation to identify the nature and extent of off-site contamination at PGDP. Phase I of the site investigation, which extended from summer 1989 to March 1991, evaluated the extent of off-site contamination at PGDP through extensive groundwater monitoring and surface water sampling. Results of the Phase I activities are reported in Results of the Site Investigation, Phase I (CH2M Hill 1991b). Phase II of the site investigation, which extended from November 1990 to October 1991, focused on identification and characterization of the on-site sources contributing to the off-site contamination, determined the level of risk to human health and the environment from exposure to contaminated media and biota, and developed an initial list of remedial alternatives. Results of the Phase II site investigation are reported in Results of the Site Investigation, Phase II (CH2M Hill 1992a). The principal findings of the site investigation follow:

- $\mathrm{TCE}$ and ${ }^{99} \mathrm{Tc}$ are the primary contaminants in off-site groundwater at PGDP.

- A northwest and northeast groundwater plume extending off-site was delineated.

- PCBs and radionuclides were the primary contaminants detected in surface water and sediment in outfalls, ditches, and creeks around PGDP.

- Several on-site sources were identified as potential contributors to off-site contamination.

Risks to human health and the environment from exposure to contamination originating at PGDP were reported in Results of the Public Health and Ecological Assessment, Phase II (CH2M Hill 1992b). This report used data collected during the site investigation to quantitatively assess risks to human health and to qualitatively assess risks to the environment. A range of preliminary alternatives that may be used to address the contamination was also developed as part of the ACO activities. This material is presented in Summary of Alternatives for Remediation of Off-Site Contamination at the Paducah Gaseous Diffusion Plant, Paducah, Kentucky (Draft) (SAIC 1991a). Upon completion of the Phase II activities and in response to the risks identified in the public health and ecological assessment, PGDP initiated the development and implementation of several interim remedial actions designed to prevent further off-site migration of contaminants and to reduce risks to human health and the environment. The actions targeted the certain on-site sources and the off-site contamination associated with groundwater and surface water.

Surface water actions included institutional controls (posting and fencing) for outfalls, creeks, and lagoons to which the public can gain access and in which there may be contaminated sediment, surface water, or biota.

\section{2-4 Environmental Compliance}


These actions have been completed and are documented in Interim Corrective Measures Report for Institutional Control of Off-Site Contamination in Surface Water (SAIC 1993c). The final action for the surface water unit will be evaluated after releases from contributing source units have been mitigated and the remedial investigation/feasibility study (FS) for the surface water unit is complete.

Interim actions have also been initiated for groundwater to reduce the current risks to human health and to prevent further off-site migration of contaminants. As part of the routine residential sampling that began when off-site contamination was discovered. DOE established a water policy. The policy states that in the event that contamination originating from PGDP is detected above plant action levels, which are established at the analytical laboratory detection limits of $25 \mathrm{pCi} / \mathrm{L}$ for ${ }^{99} \mathrm{Tc}$ and $1 \mathrm{mg} / \mathrm{L}$ for TCE, a response will be initiated by PGDP. Accordingly, residents are notified immediately; state and EPA officials are also notified. Alternative water supplies are provided through connections to municipal water systems, or in the event of a time lag between discovery and the ability to complete connections, bottled water is made available. DOE would pay the cost of installation of water systems and the monthly charges for water service to residents with contaminated wells.

However, DOE recently modified the water policy to include provisions to extend a municipal water line to the entire area potentially affected by groundwater contamination originating from PGDP. All residents within the affected area, regardless of whether or not their wells are contaminated, would be given the option to receive municipal water at DOE expense. Of the 83 eligible property owners, 73 signed agreements not to use or dig wells on their property. Any eligible resident who did not sign a license agreement before November 1, 1993 (with the exception of those with wells contaminated from the plant), and anyone who establishes residence after that date will not be provided municipal water at DOE expense. Construction to extend the municipal water line was completed in 1994.

Because of the extension of the municipal water line, the new water policy allows reduction in the number and frequency of residential wells sampled routinely. This modification will provide for a more cost-effective allocation of well-sampling resources and, through the strategic placement of additional monitoring wells, will allow more accurate data on the location and movement of the contaminated groundwater.

The water policy change was implemented as a removal action under CERCLA. The new water policy and other options that were under consideration were originally proposed in an engineering evaluation/cost analysis report, which was approved by the EPA on August 13, 1993, and the commonwealth of Kentucky on August 25, 1993. The report was made available for public review and comment from August 12 to September 12, 1993. Following the public comment period, a final decision to implement the new water policy was documented in the action memorandum.

In addition to the new water policy, a series of interim actions has been proposed for the northwest plume. The first interim action, initially documented in Technical Memorandum for Interim Remedial Action of the Northwest Plume (SAIC 1993f), was developed to evaluate groundwater extraction and treatment to reduce the spread of contamination from the source and centroid of the northwest plume. The Proposed Plan for Interim Remedial Action of the Northwest Plume (SAIC 1993d), which summarizes the interim alternatives, was approved by the EPA on April 15, 1993. The Record of Decision for Interim Remedial Action of the Northwest Plume (SAIC 1993e) was signed by DOE on July 15, 1993, and by the EPA on July 22, 1993. Construction activities to implement the interim action are under way and are scheduled to be completed during 1995.

The second interim action for the northwest plume is in the FS process. The FS will evaluate additional remedial alternatives that may be used to contain the sources of the northwest plume. A draft FS report for this action was submitted to the EPA and the state for review and comment on January 28, 1994. A proposed plan recommending the preferred remedial alternative for this action will be developed after the FS process is complete. A final action for the northwest plume is expected to be developed following completion of the second interim action. An interim action for the northeast plume will be evaluated after additional characterization has been completed. The characterization efforts proposed for the northeast plume are documented in a RCRA interim corrective measures work plan and corresponding field sampling plan, which were submitted to the EPA and the state for review on October 4, 1993, and January 12, 1994, respectively.

In addition to the interim actions initiated for surface water and groundwater, PGDP has proposed and implemented several interim measures for the on-site source units that were identified as contributing to off-site contamination. These actions include containment of leachate seepage at the $\mathrm{C}-746-\mathrm{K}$ landfill and interim measures to contain runoff and migration of contaminated sediment from certain scrap yards and the north-south 
diversion ditch. Actions for the remaining on-site sources (e.g., burial grounds, PCB sites) that are contributing to off-site contamination are being evaluated as part of two separate FSs for WAGs 22 and 23.

All commitments required under the ACO have been completed on schedule. The actions and documentation generated during Phase I and Phase II activities have been designed to meet the objectives of the ACO. Schedules and priorities for additional response actions initiated under the ACO that pertain to off-site contamination will be outlined in the annual Site Management Plan. The plan will serve as the primary strategy document for remediation activities at PGDP. A site management plan is required by the FFA and must be submitted annually to the EPA and the commonwealth of Kentucky. When the plan is signed, its project schedules will become enforceable commitments under the FFA.

\section{CERCLA NOVS}

No CERCLA NOVs were received in 1993.

\section{CERCLA-Reportable Quantities}

During 1993, PGDP reported four reportable quantities to the National Response Center and state agencies. These reportable quantities consisted of three ethylene glycol violations and one PCB violation; these four spills were contained on-site and were properly cleaned up. Table 2.2 depicts the pertinent information.

Table 2.2. Occurrences reported to the National Response Center and state agencies by PGDP in 1993

\begin{tabular}{lcc}
\hline \multicolumn{1}{c}{ Chemical } & Date & $\begin{array}{c}\text { Amount } \\
\text { (lb) }\end{array}$ \\
\hline Ethylene glycol & $02 / 09 / 93$ & 4.6 \\
Ethylene glycol & $05 / 06 / 93$ & 4.6 \\
Ethylene glycol & $11 / 04 / 93$ & 1.5 \\
PCBs & $06 / 05 / 93$ & 40 \\
\hline
\end{tabular}

\section{Federal Facilities Compliance Act (FFCACt)}

The FFCAct was enacted in October 1992. The FFCAct waived the immunity from fines and penalties that had existed for federal facilities for violations of solid and hazardous waste management requirements. As a result of the complex issues and problems associated with mixed chemical hazardous and radioactive waste (mixed waste) and the lack of treatment and disposal capacity, the FFCAct allowed a three-year extension for DOE facilities to prepare schedules and plans on how they would manage their mixed waste in compliance with applicable RCRA regulations. DOE was required to submit to the EPA and state agencies an inventory of mixed wastes, including waste generation volumes and characterizations [the Mixed Waste Inventory Report (MWIR)], by April 1993. In addition, annual updates to the MWIR are to be submitted by March of each year. The three-year waiver can be extended provided that a mixed waste treatment plan and compliance schedule are approved by the appropriate agency or agencies and is adhered to by the facility.

To facilitate compliance with the FFCAct and address the myriad of complex issues involved, PGDP initiated a four-phase approach. The first phase consisted of gathering required information and submitting the MWIR, which was completed in April 1993. The second phase involved the development of a conceptual site treatment plan (CSTP). PGDP submitted the CSTP in October 1993. The CSTP investigates existing treatment capacity for facility wastes and, where existing capacity does not exist, provides initial information on potential treatment technologies or options that can be employed to meet operational requirements. The third phase is to expand the CSTP to identify treatment options that are both environmentally and economically preferred. The information gathered by the ongoing waste characterization program detailed in the MWR and the technology evaluation and development program outlined in the CSTP will be combined in a draft site treatment plan (DSTP). The DSTP is being prepared and is scheduled for submission to the appropriate agencies in June 1994. 
The fourth phase of the PGDP FFCAct program is to gather agency comments on the DSTP and finalize the PGDP Mixed Waste Treatment Plan. The finalized plan will be submitted as the Site Treatment Plan. This plan will detail how much mixed waste is to be treated, the physical and chemical characteristics of the waste, where it will be treated and disposed of, and a schedule and estimated cost for treatment and disposal. The STP is scheduled for submission in March 1995.

\section{FFCAct NOVs}

PGDP is on schedule in the development and preparation of the CSTP and DSTP and is in compliance with the FFCAct. No NOVs were received during 1993.

\section{Underground Storage Tanks (USTs)}

USTs store petroleum products, such as gasoline, diesel fuel, and heating oil. The tanks are regulated under Subtitle I and Subtitle C of RCRA.

The UST program includes 15 USTs, the status of which follows.

- Active/in-service petroleum USTs (two)-The two existing tank systems were installed in February 1992.

These USTs were installed within regulatory requirements and do not need upgrading before the December 22, 1998, deadline.

- USTs excluded from regulation (three)-Two USTs contain heating oil and have no regulatory driver. One UST is excluded from regulation because its volume is less than 110 gal. This UST will be investigated pursuant to HSWAs.

- HSWA Permit Differed USTs (seven)-These tanks will be required to close the USTs pursuant to Title 40, Code of Federal Regulations, Part 280, Subpart G (40 CFR 280, Subpart G), including notification (Notice of Intent to Close), removal of the USTs by a certified tank removal contractor, and investigation. It is noted that PGDP has been allowed to defer the investigation for these tanks to the HSWA permit until Environmental Restoration removes the tanks.

- Closed USTs (three)—One UST has been closed pursuant to RCRA, Subtitle C. Two USTs have been closed pursuant to RCRA, Subtitle I. Results of the investigation are still being reviewed by the KDWM.

\section{UST Program NOVs}

No NOVs were received regarding the UST program.

\section{National Environmental Policy Act (NEPA)}

NEPA provides a means to evaluate the potential environmental impact of proposed federal activities and to examine alternatives to those actions. Compliance with NEPA, as administered by the DOE NEPA Implementing Procedures (10 CFR 1021) and Council on Environmental Quality regulations (40 CFR 1500-1508), ensures that consideration is given to environmental values and factors in federal planning and decision making. To strengthen its NEPA review and documentation process, DOE promulgated its new NEPA regulations on May 26, 1992. These new regulations expanded the list of categorical exclusions (CXs) available for use and refined DOE's NEPA Implementing Procedures to more closely parallel Council on Environmental Quality regulations.

\section{MMUS Activities}

The USEC adopted a corporate environmental review policy (which was reviewed and accepted by the Council on Environmental Quality on November 30,1993) closely patterned after the DOE NEPA Implementing Procedures. The policy was published in the Federal Register on December 7, 1993 (53 FR 233).

MMUS Environmental Review personnel conducted reviews on all engineering service orders, engineering service requests, and work orders following the transition. Each review resulted in the activity being categorically 
excluded from further environmental review and documentation. The following is a summary of the reviews conducted from July 1, 1993, to December 31, 1993.

Engineering service orders

Engineering service requests

Work orders
14

41

2047

\section{Martin Marietta Energy Systems, Inc. (MMES), Activities}

The MMES NEPA compliance program maintains compliance with NEPA through use of its plant and administrative procedures. Each proposed project is subjected to a documented NEPA review. Support organizations such as MMUS Maintenance and Environmental Restoration and Waste Management Site Engineering also have internal procedures that define additional review and documentation steps to streamline the NEPA review process.

In CY 1993, MMES NEPA Compliance received 13 approved CX determinations from DOE-Oak Ridge Operations. In addition, NEPA Compliance approved 37 other projects by applying previously approved, generic CXs. The DOE PGDP Site Office and the DOE-Oak Ridge Operations NEPA compliance officer approved this approach and monitored the process through review of documentation. MMES NEPA Compliance uses five generic CXs for activities such as routine maintenance and small-scale modifications.

Environmental assessments (EAs) are typically prepared by DOE-direct contractors and are subject to review and revision by MMES. At the end of 1993, two EA determinations were approved by DOE and two EAs were being reviewed.

No environmental impact statement (EIS) determinations or EISs were issued during 1993. A programmatic EIS is being prepared by DOE Headquarters to develop a systematic, integrated approach to environmental restoration and waste management. Such an integrated program is needed to ensure a consistent and efficient nationwide approach at all DOE sites. To date, development of the programmatic EIS has not directly affected PGDP.

Increased emphasis is being placed on early identification of potential impacts from proposed projects on environmentally sensitive resources such as wetlands, floodplains, cultural resources, federally and state-listed species and habitats, and prime farmland. In conjunction with the NEPA process, all proposed projects are reviewed for compliance with the Endangered Species Act of 1973, the National Historic Preservation Act of 1966, DOE Compliance with Floodplain/Wetlands Environmental Review Requirements (10 CFR 1022), and the Farmland Protection Policy Act of 1981. To support these efforts, MMES has coordinated an interagency agreement between DOE and the U.S. Army Corps of Engineers to have the Corps identify wetlands, floodplains, federally and state-listed threatened and endangered species and their habitats, and cultural resources on about 4050 ha (10,000 acres) surrounding PGDP. Information from the final Corps of Engineers report, due by April 1994, will be incorporated into project planning to decrease the potential for impacts to environmentally sensitive resources. Further discussion regarding NEPA compliance efforts is provided in the following.

NEPA Compliance also works to establish effective communication with program managers and project engineers with the goal of establishing NEPA as a key consideration in project planning. This communication is accomplished by conducting NEPA training programs, distributing NEPA guidance memorandums, and working one-on-one with program and project personnel.

Table 2.3 summarizes the documents prepared in support of NEPA compliance efforts in CY 1993; this list includes documents prepared by or for MMES that were submitted (or revised and resubmitted) to DOE during 1993.

\section{Other Environmental Acts}

\section{National Historic Preservation Act (NHPA)}

The NHPA of 1966 is the primary law governing the protection of cultural resources (archaeological and historical properties). DOE and PGDP are in the process of developing procedures to ensure compliance with the NHPA. Cultural resource reviews are conducted on a case-by-case basis, and consultations with the Kentucky State Historic Preservation Officer are made through DOE as required by Section 106 of the NHPA.

\section{2-8 Environmental Compliance}


Table 2.3. NEPA documentation for CY 1993

\begin{tabular}{lc}
\hline \multicolumn{1}{c}{ Documentation type } & No. submitted to DOE \\
\hline CXs & 11 \\
Memorandums documenting application of generic $\mathrm{CXs}^{a}$ & 37 \\
Environmental assessment determinations & 3 \\
Environmental assessments & 6 \\
Environmental impact statement determinations & 0 \\
Environmental impact statements & 0 \\
Supplemental environmental impact statements & 0 \\
Wetlands assessments & 1 \\
Floodplain assessments/statements of findings & 2 \\
\hline
\end{tabular}

${ }^{a}$ Generic CX approval memorandums are issued internally by MMES and do not require prior submittal to DOE.

\section{Endangered Species Act}

The Endangered Species Act of 1973, as amended, provides for the designation and protection of rare and threatened wildlife and plants. The act also serves to protect ecosystems on which such species depend. Field surveys are performed and mitigating measures are designed as needed. When appropriate, formal consultations with the U.S. Fish and Wildlife Service and the Kentucky Department of Fish and Wildlife Resources are made through DOE.

\section{Compliance with Floodplain/Wetlands Environmental Review Requirements (10 CFR 1022)}

The DOE Compliance with Floodplain/Wetlands Environmental Review requirements establish policy and procedures for compliance with Executive Order 11988, "Floodplain Management" and Executive Order 11990, "Protection of Wetlands." Activities proposed within 100-year and 500-year floodplains or in wetlands (other than routine maintenance) first require that a notice of involvement be published in the Federal Register. Then a floodplain or wetlands assessment must be prepared and submitted to DOE for approval. These assessments must discuss the effects of the proposed project on the floodplain or wetland and any alternatives or mitigating measures that would lessen adverse impacts. For floodplains, a floodplain statement of findings summarizing the floodplain assessment must also be approved by DOE and published in the Federal Register for public comment at least 15 days before beginning the project.

PGDP submitted two floodplain assessments and one wetlands assessment to DOE for approval. A second wetlands assessment was also incorporated in the EA for PGDP waste storage facilities. None of these were approved as of the end of CY 1993.

\section{Farmland Protection Policy Act}

The Farmland Protection Policy Act of 1981 requires federal agencies to consider the effects of their proposed actions on prime farmland. Prime farmland is generally defined as land that has the best combination of physical and chemical characteristics for producing crops of statewide or local importance. When required, prime farmland surveys are conducted and consultations with the U.S. Department of Agriculture Soil Conservation Service are made through DOE.

PGDP consulted with the Soil Conservation Service regarding two prime farmland surveys in CY 1993. These consultations were in support of the EAs for the proposed solid waste landfill and PGDP waste storage facilities. 


\section{Safe Drinking Water Act (SDWA)}

PGDP operates a "nontransient, noncommunity" public water system subject to regulation by the Kentucky Division of Water (KDOW). The water treatment facility is a Class II facility. Ten on-site operators have Class II or higher operating certification. Monthly reports describing operational activity for the facility are provided to the KDOW. Ongoing training required to maintain certification is provided by a program developed in-house, which the commonwealth of Kentucky has approved as meeting KDOW requirements.

In 1993, surveys of the sanitary water supply system indicated that PGDP drinking water met all state and federal regulations for maximum contaminant levels for the required inorganic parameters. In 1993, PGDP completed a quarterly survey of the sanitary water system for eight regulated volatile organic compounds. None of the regulated compounds were detected.

\section{SDWA NOVs}

No NOVs of the SDWA were issued in 1993.

\section{Clean Water Act (CWA)}

The CWA was established primarily through the passage of the Federal Water Pollution Control Act Amendments of 1972. The CWA established four major programs for control of water pollution: (1) a permit program regulating point source discharges into U.S. waters, (2) a program to control and prevent spills of oil and hazardous substances, (3) a program to regulate discharges of dredge and fill materials into U.S. waters, and (4) a program to provide financial assistance for construction of publicly owned sewage treatment works.

In 1993 the Oil Pollution Act required a substantial harm facility to submit a facility response plan to the EPA. PGDP deemed itself a substantial harm facility and complied with the act by submitting a facility response plan to EPA Region IV in February 1993.

\section{KPDES}

The CWA applies to all nonradiological discharges to navigable surface waters. At PGDP the regulations are applied through a KPDES permit for effluent discharges to Big Bayou and Little Bayou creeks. The KDOW issued KPDES permit No. KY0004049 to PGDP in September 1992. This permit became effective on November 1, 1992, and is enforced by the KDOW. In June 1993, the KDOW added USEC as a joint owner of the KPDES permit. At the request of PGDP, the commonwealth of Kentucky granted a stay of permit limits for $\mathrm{pH}$, metals, temperature, chromium, phosphorous, and toxicity in October 1992. PGDP is working with KDOW to establish an agreed order concerning the final effluent limits for these parameters. All other conditions stated in the permit are in effect.

Effluent discharges occur at 18 outfalls. No exceedences of effluent limits occurred in 1993. One oil sheen was discovered at an outfall in January 1993. All water analytical results generated from environmental restoration activities and plant operations must be reviewed and approved for discharge by Environmental Compliance. High priority has been placed on erosion control at construction projects to stop suspended solids violations. The compliance rate of PGDP with the KPDES permit during 1993 was $100 \%$.

\section{CWA NOVS}

PGDP received no NOVs of the CWA during 1993.

\section{Toxic Substances Control Act (TSCA)}

TSCA was enacted in 1976 with a twofold purpose: (1) to ensure that data on the production, use, and environmental and health effects of chemical substances or mixtures are obtained by the EPA and (2) to provide the means by which the EPA may regulate the manufacture, processing, distribution in commerce, use, and disposal of chemical substances or mixtures. Other sections of TSCA do not apply, or activity was minimal.

\section{2-10 Environmental Compliance}




\section{PCBs}

PGDP uses PCBs and generates PCB wastes. The Uranium Enrichment FFCA (UE-FFCA) between the EPA and DOE was signed in February 1992. Under this agreement, action plans have been developed and implemented for removal and disposal of large volumes of PCB material at PGDP. Quarterly meetings between DOE and EPA representatives have facilitated implementation of the agreement.

The number of PCB transformers at PGDP was reduced by three in 1993, one through request for disposal and two by reclassification as PCB contaminated $(<500 \mathrm{ppm})$. This reduction was accomplished through draining, reclassification, and removal from service efforts of the past 2 years. Decontamination and decommissioning efforts are under way to remove the drained transformers and PCB capacitors from the site. Tables 2.4 and 2.5 show the 1993 data.

Table 2.4. Large, high-voltage PCB capacitors at PGDP in 1993

\begin{tabular}{cccc}
\hline $\begin{array}{c}\text { Building } \\
\text { location }\end{array}$ & $\begin{array}{c}\text { Beginning balance, } \\
1 / 1 / 93\end{array}$ & $\begin{array}{c}\text { Capacitors } \\
\text { removed }\end{array}$ & $\begin{array}{c}\text { New balance, } \\
12 / 31 / 93\end{array}$ \\
\hline C-331 & 219 & 0 & 219 \\
C-333 & 2144 & 39 & 2105 \\
C-335 & 235 & 58 & 177 \\
C-337 & 4500 & 1959 & 2543 \\
C-533 & $837^{a}$ & 813 & 0 \\
C-537 & $630^{a}$ & 612 & 0 \\
Total & 8565 & 3481 & 5084 \\
\hline
\end{tabular}

${ }^{a}$ All capacitors were removed from C-533 and C-537 during 1993. Beginning balances were based on estimates of previous inventories; capacitors removed were based on disposal records when the capacitors were placed in storage for disposal.

Major near-term plans include

- pursuing EPA approval of a PCB drum wash station to decontaminate PCB containers and

- completion of the 1993 annual PCB document (due July 1994).

All PGDP UE-FFCA milestones either have been completed or are proceeding on schedule.

Storage, control, and disposal of PCBs and PCB items are regulated by TSCA and the UE-FFCA. Several projects have begun to reduce such items; these projects include annual audits to inventory regulated PCBs and sampling to ensure regulatory compliance with testing requirements of hydraulic, heat-transfer, and lubricating systems. Per 40 CFR 761, such systems may be used if the PCB concentration is less than $50 \mathrm{ppm}$.

PGDP generates an annual PCB report for submission to the EPA and KDEP. The report provides details of PCBs and PCB items that are in use, stored for disposal, generated during the year, and disposed of throughout the year.

PGDP manages all nonradioactive contaminated PCBs in compliance with federal regulations. The facility operates equipment that contains PCB capacitors as well as transformers, pumps, electrical equipment, and other miscellaneous equipment that contains PCB-contaminated oil. Both radioactive and nonradioactive PCB wastes are stored on-site in storage units that meet compliance requirements. Nonradioactive PCBs are transported off-site to EPA-approved facilities for disposal in accordance with regulatory requirements. Drums of radioactively contaminated $\mathrm{PCB}$ waste are stored on-site awaiting disposal. Continued storage of radioactively contaminated PCB waste beyond one year is covered in the UE-FFCA.

The focus of the PGDP TSCA Compliance Program is on compliance with PCB regulations. The program concentrates on two major functions: (1) producing compliance documents and reports and (2) providing 
Table 2.5. Summary of PCB and PCB items in service as of December 31, 1993

\begin{tabular}{|c|c|c|c|}
\hline Type & $\begin{array}{l}\text { No. in } \\
\text { service }\end{array}$ & $\begin{array}{c}\text { Volume } \\
\text { (gal) }\end{array}$ & $\begin{array}{c}\text { PCBs } \\
(\mathrm{kg})\end{array}$ \\
\hline PCB transformers & 74 & 97,796 & $284,850.2$ \\
\hline PCB-contaminated transformers & 25 & 7649 & 4.3 \\
\hline PCB-contaminated electrical equipment & 18 & 4704 & 5.0 \\
\hline PCB capacitors & 5084 & & \\
\hline PCB open systems ${ }^{a}$ & 3 & 235 & 10.9 \\
\hline
\end{tabular}

${ }^{\circ} \mathrm{PCB}$ open systems are addressed in the PGDP FFCA. In addition, ventilation gaskets used in various buildings throughout PGDP have been determined to contain PCBs. The average PCB concentration is estimated to be $20 \%$ by weight. The total PCB content is estimated at $3840 \mathrm{~kg}$ in the $19,200 \mathrm{~kg}$ of gaskets.

guidance to various organizations on issues that arise. To meet these goals, the UE-FFCA is frequently revised and updated. A clarification package to revise the UE-FFCA was submitted to EPA Headquarters for consideration.

\section{PCB NOVs}

PGDP received no NOVs regarding PCBs in 1993.

\section{Federal Insecticide, Fungicide, and Rodenticide Act (FIFRA)}

No restricted-use pesticides are used by PGDP personnel. If application of a restricted-use pesticide at the plant should be necessary, a certified contractor will be used. General-use pesticides are applied by plant personnel in a manner consistent with product labeling; all product warnings and cautions are strictly adhered to. Applications of pesticides by plant and contractor personnel must be approved by the plant pesticide coordinator. No unusual occurrences were reported for CY 1993.

\section{FIFRA NOVs}

The FIFRA program received no NOVs during 1993.

\section{Emergency Planning and Community Right-To-Know Act (EPCRA)}

EPCRA, also referred to as SARA, Title III, requires that inventory and environmental release information on certain chemicals at a facility be reported to federal, state, and local authorities. This information is used for emergency planning and to provide information to the public. EPCRA requires that local and state emergency planning commissions be informed of the amount of hazardous and extremely hazardous substances that are present on-site and that a material safety data sheet for each chemical be available on request. The regulation also requires that releases of toxic chemicals to the environment be reported each calendar year if specified threshold limits are reached.

The Emergency Planning and Hazardous Chemical Inventory Report was submitted to state and local emergency planning commissions in March 1993. The Toxic Chemical Release Inventory Reporting Form $R$ was submitted to the state and the federal EPA before July 1, 1993. Material safety data sheets are kept on-site and are available on request through the PGDP Hazard Communication Program.

No extremely hazardous substances were released above reportable quantities, and all CERCLA-reportable spills were contained on-site. Therefore, no spills were reported under SARA, Title III, Section 304. 


\section{EPCRA NOVs}

No NOVs were received for the EPCRA program during 1993.

\section{Clean Air Act (CAA)}

Authority for enforcement of compliance with the CAA and subsequent amendments resides with the EPA and the Kentucky Division for Air Quality (KDAQ). The EPA generally enforces rules resulting from Title VI (stratospheric ozone protection) of the CAA and regulates airborne radionuclide emissions under the National Emission Standards for Hazardous Air Pollutants (NESHAP) rule. PGDP has an ongoing program to maintain compliance with all federal and state rules resulting from the CAA and subsequent amendments. As an integral part of this program, in 1992 PGDP completed a vent/stack survey that identified all the air emission points at PGDP, and information collected during the survey was entered in a data base. Hence, compliance with permit and regulatory limits can be ascertained from this data base.

\section{Permit Status}

PGDP operates under permit No. 0-85-110, issued by the KDAQ on September 30, 1985; the permit has no expiration date. This permit contains 27 emission points. (PGDP and the KDAQ sometimes designate emission points differently. For example, the KDAQ includes all the chemical storage and transfer facilities as emission point 42; PGDP indicates these facilities as emission points 42-46.) PGDP is in compliance with conditions currently listed on the permit. Identification of emission points subsequent to issuance of the operating permit resulted in submittal to the KDAQ of permit applications for these points. Air toxic regulations promulgated in 1987 resulted in the submittal of a permit application that included air toxic emission points. An updated operating permit that includes these additional points has not been issued by the KDAQ. Many of the emission points listed on the current operating permit are now permanently removed from service.

When the USEC was formed in July 1993, it assumed responsibility for all of the operating emission points listed on the operating permit. Because of the impending permit requirements of Title $V$ of the CAA, the KDAQ will not issue an interim permit to the USEC for PGDP. PGDP will apply for a Title V permit by November 1995. The emission points retained by DOE after the formation of USEC will not be required to have an operating permit.

Title $\mathrm{V}$ of the CAA established a federally enforced permit program. The KDAQ has submitted its Title V permit program to the EPA for approval. When the KDAQ permit program is approved by the EPA, the KDAQ will solicit new permit applications from the USEC, DOE, and other sources statewide. These applications will result in issuance of new permits that comply with the requirements of Title V of the CAA.

\section{Asbestos NESHAP Program}

Numerous PGDP facilities contain asbestos materials. Compliance programs for asbestos management include identification of asbestos materials, monitoring, abatement, and disposal. Procedures are maintained that delineate scope, roles, and responsibilities for maintaining compliance with EPA, Occupational Safety and Health Administration, and Kentucky regulatory requirements (no nonconformances with environmental protection standards were identified in 1993).

\section{Radionuclide NESHAP Program}

The 1989 promulgation of 40 CFR 61, Subpart $\mathrm{H}$, which regulates airborne radionuclides from DOE facilities, resulted in an FFCA between PGDP and EPA Region IV in 1992. The FFCA required PGDP to perform confirmatory sampling on the C-310 purge cascade/product cylinder burp stack, develop a quality assurance plan for the C-310 continuous sampler, identify all radionuclide emission points, submit monthly compliance reports, and submit a revised compliance plan to the EPA. PGDP completed all the requirements on or before the dates specified in the FFCA. The EPA certified that the FFCA was fulfilled and that PGDP was in compliance with 40 CFR 61, Subpart H, in March 1993. 
There is no EPA permit program that covers radionuclide NESHAP at PGDP. However, the Nuclear Regulatory Commission (NRC) is expected to begin regulating the USEC in 1995. The NRC is expected to issue a certificate of compliance to PGDP based on applications it submits. PGDP is in the preliminary stages of application development.

PGDP has one airborne radionuclide source, the C-310 stack, which is continuously sampled as required by $40 \mathrm{CFR}$ 61, Subpart $\mathrm{H}$. The processes that supply effluents to the $\mathrm{C}-310$ stack are the product cylinder burp station and the purge cascade. The radionuclides of concern are uranium, ${ }^{99} \mathrm{Tc},{ }^{237} \mathrm{~Np},{ }^{239} \mathrm{Pu}$, and ${ }^{230} \mathrm{Th}$. Technetium- $99,{ }^{237} \mathrm{~Np}$, and ${ }^{239} \mathrm{Pu}$ are fission by-products remaining in the cascade from the use of reactor tails as feed materials. This practice was discontinued in the mid-1970s. Thorium-230 is a long-lived daughter of uranium decay. Emissions of these radionuclides are in minute quantities and are rarely detectable by the C-310 sampling system.

Other minor radionuclide emission points that are not continuously sampled are the seal exhaust and wet-air exhaust process vents, the cylinder connection (pigtail) exhaust stacks, laboratory hoods, decontamination activities, and cylinder connection activities that do not take place under an exhaust hood. The seal and wet-air exhaust stacks and the pigtail exhaust stacks were sampled in 1992 and are scheduled for confirmatory sampling on a five-year basis. Emissions from the other minor emission points are estimated by the method outlined in Appendix D of 40 CFR 61, Subpart $\mathrm{H}$.

In 1993 total radionuclide emissions from PGDP resulted in an off-site effective dose equivalent of 0.0023 mrem to the most affected resident. This dose is less than $1 \%$ of the standard of 10 mrem established in 40 CFR 61, Subpart H.

\section{CAA Amendments of 1990}

These amendments are divided into six major titles. The titles that have the greatest impact on PGDP are Title III, Hazardous Air Pollutants; Title V, Permitting; and Title VI, Stratospheric Ozone Protection.

To date, the only sources affected by Title III are the gaseous diffusion process cooling towers. Under Title III, the Maximum Achievable Control Technology standard for industrial process cooling towers, proposed in August 1993, prohibits the use of chromium compounds as corrosion inhibitors in recirculating cooling water. Before publication of the proposed rule, PGDP had initiated a plan to switch from a chromium-based corrosion inhibitor to a phosphate-based inhibitor. PGDP will be in compliance with the final rule on or before its specified date.

As stated previously, the KDAQ has submitted its Title $\mathrm{V}$ permitting program to the EPA for approval; therefore, the KDAQ has not yet published updated permit application forms. When these forms are available, PGDP will examine them and determine whether to prepare the Title V permit application or to subcontract this effort.

Title VI of the amendments regulates substances that deplete the stratospheric ozone. The greatest impact resulting from EPA rules promulgated to implement Title VI is on the gaseous diffusion cascade coolant system, which uses chlorofluorocarbon (CFC)-114, an ozone depletor, as a coolant. PGDP is in compliance with Title VI rules and will closely follow promulgation of additional rules pertaining to labeling of substances that contain stratospheric ozone depletors and training requirements for technicians who perform maintenance on industrial refrigeration equipment. PGDP has successfully tested an alternative coolant that does not deplete ozone. This alternative has been approved by the EPA.

\section{CAA NOVs}

PGDP received an NOV during the annual KDAQ inspection in July 1993 for visible emissions greater than $20 \%$ opacity from the C-600 coal-fired boiler No. 2. PGDP responded by shutting down the boiler and starting boiler No. 3. The electrostatic precipitator on boiler No. 2 was repaired and upgraded, and boiler No. 2 was restarted in February 1994. PGDP notified the KDAQ of the restart, and the KDAQ performed an unannounced compliance inspection on boiler No. 2 in March 1994. The boiler was under malfunction status at the time, and the opacity exceeded the standards. Boiler No. 2 was shut down, and boiler No. 3 was restarted as soon as possible. The KDAQ is evaluating coal analysis information and electrostatic precipitator operating parameters in an effort to close this issue.

\section{2-14 Environmental Compliance}




\section{Kentucky/DOE Agreement in Principle (AIP)}

An AIP is a written agreement entered into between DOE and the commonwealth of Kentucky, specifically, the Natural Resources and Environmental Protection Cabinet and the Cabinet of Human Resources. The AIP requires that DOE provide Kentucky with financial support for oversight activities defined in the attachments to the agreement. These oversight activities focus primarily on environmental monitoring, environmental restoration, waste management, emergency response, and public relations programs at PGDP. DOE has directed MMES to implement the AIP at PGDP.

Contained in the AIP are numerous DOE and Kentucky commitments; some are well defined with specified deadlines, although many require additional detail to define the intended scope and priority of the commitment. The many AIP commitments present a challenge to individuals and groups charged with the task of tracking commitments and reporting on the general status of AIP activities.

To date, information concerning visits by state AIP personnel has been kept on file and in the logbooks of the PGDP technical personnel visited, and when notified of the visit, a pre-visit notification form is placed in the files of the AIP coordinator and/or coordinator's assistant. The AIP coordinator is responsible for forwarding electronic mail messages summarizing the contents and outcome of any meetings with Kentucky AIP personnel. This information is included in hard copy files and in a tracking system at PGDP.

Recently, the MMES Regulatory Integration Department reassessed the agreement and identified all DOE deliverables. These deliverables have been entered into the Environmental Restoration Waste Management Centralized Tracking System to allow appropriate attention to be given to completion and to provide a mechanism for producing progress reports. Also entered into the tracking system are activities associated with the AIP, as stated previously. Although this list of activities may not be comprehensive, it does serve as an indicator of the types of activities being performed at PGDP under the agreement. With the implementation of the pre-visit notification form submitted to PGDP from KDEP, PGDP activity tracking is now more complete.

Coordination efforts are under way to begin renegotiating the AIP based on the draft FFA. A grant similar to the AIP grant will be associated with the FFA. A Kentucky-AIP program management plan that will more clearly define activities and policies associated with the AIP is being developed.

\section{DOE Order Compliance}

\section{DOE Order 5400.1, General Environmental Protection Program}

DOE Order 5400.1 provides directives for compliance with EPA, state, and local environmental regulations and establishes requirements for internal environmental protection programs. PGDP maintains compliance with this order through implementation of the regulatory requirements of CAA, CWA, RCRA, TSCA, SDWA, and other federal and state environmental statutes.

Internal environmental management programs include notification and reports such as the radioactive effluent and on-site discharge data report submitted annually to the Waste Information Systems Branch of EG\&G Idaho Inc., Idaho Falls, Idaho; the five-year plan required by the Office of Management and Budget Circular A-106; the annual site environmental report; and reports of significant nonroutine releases of hazardous substances consistent with DOE Order 5000.3B, Occurrence Reporting and Processing of Operations Information. An Environmental Protection Implementation Plan has been developed and is updated annually; the last update was made in November 1993. This plan defines specific environmental objectives, including the means and schedules for accomplishment.

DOE Order 5400.1 also requires an environmental monitoring plan (EMP) and that the plan be reviewed annually and updated every three years. The plan was not reviewed in 1993 because of a combination of the DOE-USEC transition and personnel reassignments before the transition. The plan defines effluent monitoring and environmental surveillance activities at PGDP. Environmental media in pathways significant to the exposure of man and the environment are included in the monitoring program, specifically, surface water, groundwater, air, and biological media.

Because of personnel changes before and after the DOE-USEC transition, the Environmental Monitoring Plan and Pollution Prevention Awareness Plan did not receive an annual review in 1993. Personnel are now in place to fulfill the document review requirements of DOE Order 5400.1. 


\section{Waste Minimization/Pollution Prevention Program}

The Waste Minimization/Pollution Prevention Program for MMES and MMUS is designed to meet the compliance requirements of the RCRA regulations (40 CFR 264.73), DOE Order 5820.2A, the FFCA LDRs, and the Kentucky/DOE AIP, all of which require waste generators to develop and implement a Waste Minimization Program. The Waste Minimization/Pollution Prevention Program includes all solid wastes (as defined by RCRA and those regulated under the Solid Waste Disposal Act) generated for disposal, as well as discharges to the environment via air and water. These wastes include hazardous, PCB, mixed, PCB-radioactive, conventional (residential and inert), low-level, and other special wastes. Generation sources include routine plant operations, spill cleanups, environmental restoration, construction, and other on-site activities. The Waste

Minimization/Pollution Prevention Program provides methodologies to reduce waste storage space requirements, waste toxicity, and waste disposal and waste characterization costs and to lower emissions to the air and water. The Pollution Prevention Awareness Program required by DOE Order 5400.1 has been incorporated in the Waste Minimization Program. The purpose of the Pollution Prevention Awareness Program is to foster the philosophy that prevention is superior to remediation.

\section{Groundwater Protection Program}

The PGDP Groundwater Protection Program serves to “. . . determine and document the effects of operations on groundwater quality and quantity . .." as outlined in DOE Order 5400.1. Compliance is specified in the following documents: Groundwater Protection Program Management Plan (Miller and Douthitt, 1993), Groundwater Monitoring Plan (Early, Sigmon, and Williams 1989), and Environmental Monitoring Plan (MMES 1992a).

RCRA groundwater monitoring is required under two separate sections of the regulations, applying to units that are under interim status or that are regulated (and therefore have a RCRA permit). Currently, the only RCRA facility at PGDP that requires groundwater monitoring is the C-404 low-level radioactive waste burial ground. Groundwater monitoring, which is conducted quarterly, indicates that there has been no release to the uppermost aquifer (the regional gravel aquifer).

With the discovery of contamination in the groundwater north of the plant in August 1988, DOE and the EPA entered into an ACO under CERCLA (Sections 104 and 106) to determine the nature and extent of off-site contamination. The EPA ACO requires monthly sampling of plant well MW-66 and potentially affected wells for TCE, technetium, and gross alpha and beta activity.

Compliance monitoring requirements exist for facilities C-746-S and C-746-T, which are permitted by KDWM. Sample frequency and analyses are dictated by the specific permit for each facility. Active and postclosure monitoring is required for the C-746-S landfill. The C-746-T industrial landfill is awaiting certification of closure. Post-closure monitoring will be required as soon as certification is received according to state permit requirements. Quarterly sampling is required for the permitting of a new landfill site (cell 3 of the C-746-S landfill) and post-closure groundwater monitoring for cell 2 , a closed cell at the C-746-S landfill.

\section{DOE Order 5400.5, Radiation Protection of the Public and the Environment}

DOE Order 5400.5 provides guidance and establishes radiation protection standards designed to protect the public and the environment against undue risk from operations of DOE and DOE contractors. The order requires that off-site radiation doses not exceed $100 \mathrm{mrem} /$ year for all pathways. During 1993 the worst-case estimated dose was $2.1 \mathrm{mrem} /$ year, including a $2.0 \mathrm{mrem}$ dose from sediments and direct radiation in Little Bayou Creek. PGDP conducts various modeling and dose-calculation activities to address the potential for multiple-pathway exposures of the public.

PGDP is also well below all applicable media-specific dose limits, such as the EPA limit of $10 \mathrm{mrem} / \mathrm{year}$ from airborne emissions and the DOE derived concentration guidelines for specific radionuclides in surface water discharges. At times during 1993, some PGDP storm water and wastewater discharges from areas with legacy contamination exceeded the PGDP internal investigation level of $10 \%$ of the derived concentration guidelines. These areas are targeted for further investigation and remediation under the ongoing Environmental Restoration Program. PGDP is in compliance with the requirements of DOE Order 5400.5.

\section{2-16 Environmental Compliance}


Reporting requirements under this order are demonstrated through the Occurrence Reporting System and publication of the annual site environmental report.

\section{DOE Order 5820.2A, Radioactive Waste Management}

DOE Order 5820.2A provides that mixed waste and low-level waste shall be managed in a manner that is protective of health, safety, and the environment; minimizes generation; and complies with all applicable regulations and requirements. DOE Order $5820.2 \mathrm{~A}$ defines the requirements for treatment, storage, and disposal of radiological waste. Facilities have been identified for this purpose (e.g., Hanford, Envirocare, NSSI, and SEG). Procedures and protocols are being established to provide proper access to these facilities. PGDP has completed two shipments of soils contaminated with radionuclides to Hanford and is in the process of qualifying itself as an "Approved Hanford Generator" with a certification program.

Commercial facilities are becoming available for these activities (treatment, storage, and disposal), and DOE has provided a method of approving use of these facilities for small quantities of waste. Volume reduction of low-level waste (LLW) is provided by a commercial facility in Tennessee, and disposal of LLW and mixed waste is provided by a commercial facility in Utah. PGDP is proceeding to use the recently negotiated nationwide contract between DOE and Envirocare of Utah, Inc., for disposal of mixed waste.

LLW is segregated into four primary waste types according to applicable treatment technology and/or regulatory requirements. These waste types are (1) burnables, (2) scrap metal, (3) other nonburnables, and (4) mixed (RCRA/LLW and PCB/LLW). Storage requirements for each of these waste types diminish the potential for environmental release, but eventually the nation will have to identify and deploy disposal facilities. PGDP is in compliance with the requirements of DOE Order 5820.2A. The Waste Management Strategic Plan, KY/W-6, was issued in March 1992; the plan details PGDP's Waste Management Program strategies and compliance requirements to meet the intent of all applicable sections of the order.

\section{Other Requirements of DOE Orders}

PGDP has inspection and permitting programs for all environmental regulations as required by DOE Order 5480.4, Environmental Protection, Safety, and Health Protection Standards. Inspections to verify and maintain compliance are routinely performed. PGDP also has a compliance issue notification and tracking system in accordance with DOE Order 5400.2A, Environmental Compliance Issue Coordination. Compliance issues from audits or daily inspection activities are promptly reported per established guidelines. These issues are then tracked to closure using the appropriate computerized data base, which is either the Action Tracking Management System or the Energy Systems Action Management System.

PGDP administers assessment and permitting programs for all environmental regulations. Routine assessments are performed to maintain and verify compliance. Compliance issues resulting from audits or routine assessment activities are documented and reported to appropriate levels of management. Follow-up actions are taken to verify implementation of these corrective actions. All 10-day and final occurrence reports are prepared and submitted to PGDP Corrective Actions. From there, the reports are entered into the DOE nationwide data base.

\section{Assessments}

PGDP environmental management programs are overseen by several organizations, both outside and within the DOE complex. Each year, numerous appraisals, audits, and surveillances of various aspects of the environmental monitoring program are conducted. Table 2.6 contains a summary of the assessments conducted in CY 1993.

\section{Tiger Team Environmental Assessment}

Former Secretary of Energy Watkins' ten-point initiative to strengthen safety, environmental protection, and waste management activities at DOE production, research, and testing facilities resulted in the Tiger Team assessment of PGDP in 1990. An action plan developed in response to the Tiger Team assessment, PGDP Action Plan Response to Compliance Assessment Team Finding, was approved by Watkins on January 7, 1991. 
Table 2.6. Environmental assessments at PGDP in 1993

\begin{tabular}{|c|c|c|c|}
\hline Date & Auditor & Type & Results \\
\hline January 12 & $\begin{array}{l}\text { ER and Quality } \\
\text { personnel }\end{array}$ & $\begin{array}{l}\text { Surveillance of C-746-K } \\
\text { subsurface soil sampling } \\
\text { activities }\end{array}$ & No deficiencies \\
\hline February & $\begin{array}{l}\text { DOE-Oak Ridge } \\
\text { Operations }\end{array}$ & $\begin{array}{l}\text { Quality assurance/quality control } \\
\text { (QA/QC) investigation of ER } \\
\text { Program data collection and } \\
\text { management involvement }\end{array}$ & 20 negative findings \\
\hline March $2 \dot{5}$ & DOE surveillance & $\begin{array}{l}\text { Surveillance of work plans for } \\
\text { WAGs } 1 \text { and } 7 ; 2,3 \text {, and 14; } \\
\text { and } 13\end{array}$ & 2 findings, 3 observations \\
\hline March 29 & $\begin{array}{l}\text { PGDP QA specialist } \\
\text { group }\end{array}$ & $\begin{array}{l}\text { Surveillance of PGDP ER } \\
\text { Program WAGs } 1 \text { and } 7 \text { work } \\
\text { plans }\end{array}$ & $\begin{array}{l}2 \text { negative findings, } \\
3 \text { negative observations }\end{array}$ \\
\hline April 28 & MMES-Paducah & $\begin{array}{l}\text { Audit of PGDP Environmental } \\
\text { Compliance Program }\end{array}$ & 4 observations \\
\hline May 27 & MMES-Paducah & $\begin{array}{l}\text { Records audit and visual } \\
\text { inspection of tanks identified } \\
\text { in the RCRA Part B permit as } \\
\text { tanks used for treatment and/or } \\
\text { storage of hazardous wastes }\end{array}$ & 4 observations \\
\hline September & EPA Region IV & $\begin{array}{l}\text { Audit of monitoring at } \mathrm{C}-404 \\
\text { RCRA landfill }\end{array}$ & $\begin{array}{l}\text { No negative findings, } \\
\text { several positive } \\
\text { observations }\end{array}$ \\
\hline September 15 & $\begin{array}{l}\text { PGDP QA specialist } \\
\text { group }\end{array}$ & $\begin{array}{l}\text { Surveillance of ER Program } \\
\text { C-746-K sampling activities }\end{array}$ & No deficiencies \\
\hline September 24 & KDWM & RCRA compliance inspection & $\begin{array}{l}1 \text { negative finding } \\
\text { resulting in a notice } \\
\text { of violation }\end{array}$ \\
\hline October & $\begin{array}{l}\text { Martin Marietta } \\
\text { Corporate }\end{array}$ & $\begin{array}{l}\text { Assessment of performance and } \\
\text { regulatory compliance regarding } \\
\text { the PGDP mission and } \\
\text { environment, safety, and health } \\
\text { and quality requirements }\end{array}$ & $\begin{array}{l}19 \text { negative findings, } \\
45 \text { negative observations, } \\
9 \text { positive findings }\end{array}$ \\
\hline October $18-20$ & DOE & $\begin{array}{l}\text { Audit of selected areas of ER } \\
\text { Program }\end{array}$ & $\begin{array}{l}8 \text { proficiencies, } \\
10 \text { deficiencies, } \\
12 \text { observations }\end{array}$ \\
\hline November 19 & $\begin{array}{l}\text { Camp Dresser McKee } \\
\text { Federal Quality } \\
\text { Program }\end{array}$ & $\begin{array}{l}\text { Audit to evaluate the adequacy of } \\
\text { the Camp Dresser McKee QA } \\
\text { Program manual and the work } \\
\text { plan for WAGs } 1 \text { and } 7\end{array}$ & $\begin{array}{l}3 \text { findings, } \\
5 \text { observations }\end{array}$ \\
\hline November 30 & DOE Site Office & $\begin{array}{l}\text { Surveillance conducted on } \mathrm{C}-400 \\
\text { lime precipitation process }\end{array}$ & 2 findings \\
\hline $\begin{array}{l}\text { November } 30 \\
\text { December } 1\end{array}$ & MMES & $\begin{array}{l}\text { Technical audit of the ER Quality } \\
\text { Program Plan }\end{array}$ & $\begin{array}{l}11 \text { negative findings, } \\
1 \text { negative observation }\end{array}$ \\
\hline December 20 & DOE ER Division & $\begin{array}{l}\text { Review of QA management } \\
\text { systems and data collection }\end{array}$ & $\begin{array}{l}6 \text { findings, } \\
11 \text { observations }\end{array}$ \\
\hline December $20-21$ & DOE & $\begin{array}{l}\text { Field surveillance of PGDP ER } \\
\text { Program WAGs } 1 \text { and } 7\end{array}$ & $\begin{array}{l}5 \text { positive findings, } \\
3 \text { negative findings, } \\
11 \text { negative observations }\end{array}$ \\
\hline
\end{tabular}


During their assessment, the Tiger Team reported no noncompliance issues of a magnitude to necessitate curtailing overall operations at the plant. The Tiger Team identified a total of 199 findings and 4 noteworthy practices. Of the 199 findings, 62 pertained to environmental issues, 123 involved safety and health issues, and 14 were related to management issues ( 3 of which addressed DOE matters). Since July 1, 1993, MMES has either completed or closed six Tiger Team actions.

As of July 1, 1993, MMUS retained ownership of 32 Tiger Team findings. An internal tracking system is used to track the progress on these findings. As of December 31, 1993, of the 32 findings, 2 remain open, 1 has been placed on hold, and 29 have been completed. All other findings are the responsibility of MMES and were transferred to MMES on July 1, 1993.

\section{ENVIRONMENTAL PERMITS}

A list of environmental permits is contained in Table 2.1. Additional permit information is detailed in the following.

\section{Air Permit}

PGDP operates under permit No. 0-85-110, issued by the KDAQ on September 30, 1985; the permit has no expiration date. This permit contains 27 emission points. (PGDP and the KDAQ sometimes designate emission points differently. For example, the KDAQ includes all the chemical storage and transfer facilities as emission point 42; PGDP indicates these facilities as emission points 42-46.) PGDP is in compliance with conditions currently listed on the permit. Identification of emission points subsequent to issuance of the operating permit resulted in submittal to the KDAQ of permit applications for these points. Air toxics regulations promulgated in 1987 resulted in the submittal of a permit application that included air toxic emission points. An updated operating permit that includes these additional points has not been issued by the KDAQ. Many of the emission points listed on the current operating permit are now permanently removed from service.

When the USEC was formed in July 1993, it assumed responsibility for all of the operating emission points listed on the operating permit. The KDAQ Permit Review Branch expects to issue new, separate operating permits to the USEC and DOE in 1994. These permits will reflect information on applications submitted to the KDAQ subsequent to issuance of the 1985 permit and on emission points under control of the USEC and DOE, respectively.

Title $\mathrm{V}$ of the CAA established a federally enforced permit program. The KDAQ has submitted its Title V permit program to the EPA for approval. When the KDAQ permit program is approved by the EPA, the KDAQ will solicit new permit applications from the USEC, DOE, and other sources statewide. These applications will result in issuance of new permits that comply with the requirements of Title $\mathrm{V}$ of the CAA.

No EPA permit program covers radionuclide NESHAP at PGDP. However, the NRC is expected to begin regulating the USEC in 1995. PGDP is working on an application for a certificate of compliance from the NRC.

\section{RCRA Permits}

PGDP hazardous waste facilities are operated under a 10-year hazardous waste management permit (No. KY8-890-008-982) granted by the commonwealth of Kentucky on August 19, 1991. This permit authorizes PGDP to treat or store hazardous wastes in 10 treatment units, 16 tanks, and 4 container storage areas located at the facility.

\section{KPDES Permits}

PGDP operates under a KPDES permit issued by the KDOW, which became effective November 1, 1992. At the request of PGDP, KDOW issued a stay of permit limits for $\mathrm{pH}$, metals, phosphorous, chromium, toxicity, and temperature. All other permit conditions remain in effect. PGDP and KDOW are negotiating an agreed order for disputed limits. An agreed order should be approved and signed in the first half of 1994 . 


\section{ISSUES}

Five issues involving compliance were addressed during 1993 and are described in the following.

\section{PCB Sediment Sampling Project}

A project has been developed to collect and evaluate sediment data to provide the basis for determining the extent and risk of PCB sediment contamination in Big Bayou and Little Bayou creeks. Project completion is scheduled for fall 1994. Information from this project may enable a 1990 NOV to be closed.

\section{Oil Sheen Summary}

Only one reportable oil sheen was observed being discharged from PGDP during 1993. Spill prevention and response measures have reduced the frequency of oil sheen discharges from ten in 1991 to one in 1993.

\section{Uranium-Contaminated PCB Waste Storage}

Uranium-contaminated PCB wastes are being stored in excess of the one-year limit imposed by TSCA because of the lack of treatment and disposal capabilities. Efforts are progressing to ship nonleaking solids offsite for disposal.

\section{Moratorium on Off-Site Shipment of Waste}

A moratorium on off-site shipment (to non-DOE sites) of waste was placed on DOE facilities, including those at PGDP, in May 1991. The moratorium was put in place to prevent waste contaminated with radioactive material from being shipped to a facility not licensed to handle nuclear material. The moratorium effectively requires all waste generated at PGDP to be managed as LLW until appropriate procedures are developed and approved to ensure that selected waste streams are below detection for radioactivity. There is a severe lack of permitted storage, treatment, and disposal capacity for mixed wastes at PGDP and other DOE sites.

The off-site shipment moratorium places severe limitations on management options for RCRA hazardous waste generated at PGDP. MMES staff are working to develop appropriate procedures for DOE Headquarters approval that will allow resumption of off-site management options for waste generated at PGDP that can be demonstrated to contain no additional radioactivity. At the time this report was compiled, PGDP had completed $60 \%$ of its review of procedures to ship waste off-site.

\section{Uranium Hexafluoride Cylinder Program}

The PGDP Uranium Hexafluoride Cylinder Program is directed toward improving the safety and reliability of long-term storage of 31,000 DOE-owned cylinders. The baseline inspection of all cylinders was completed during the year; about $25 \%$ of the cylinders will continue to be inspected each year so that all cylinders are inspected every four years.

PGDP has two substandard storage yards, the $F$ and $G$ yards. $F$ yard is being renovated; 44 rows ( 3425 cylinders) have been removed to facilitate cleaning and repair of the yard. Thirty-six rows have been restacked, and approximately 820 cylinders remain to be removed and restacked. Work is scheduled to be completed in March 1994.

PGDP has one breached cylinder and plans to transfer the contents of the cylinder this fiscal year. Also, there are plans to begin cleaning the skirts of 2500 cylinders this year. Over the years, the skirted cylinders have accumulated rust, dirt, and other debris that cause moisture to be retained in the lower portion of the skirt. This project is scheduled for completion by December 31, 1995. 


\title{
3. Environmental Program Information
}

T. L. Fletcher, D. A. Hill,

V. W. Jones, N. R. Smith, and D. S. Wattier

\begin{abstract}
Environmentally related programs at Paducah Gaseous Diffusion Plant (PGDP) include programs run by the PGDP Public Affairs Department and a Waste Minimization/Pollution Prevention (WMPP) Program. The purpose of the Public Affairs programs is to inform and educate the public about site efforts to protect and restore the local environment. Activities include public briefings, publications, and special events and are designed to solicit input from the public and involve them in decision making. The goal of the WMPP Program is to minimize the generation of wastes at the plant.
\end{abstract}

\section{PUBLIC AFFAIRS PROGRAMS}

Public awareness programs are created to inform and educate individuals about site efforts to protect and restore the environment. The programs are designed for a two-way flow of information: the site presents its plans, and the public presents its comments and concerns regarding site operations. Awareness activities include public briefings, publications, and special events.

\section{Neighborhood Council}

The Paducah Gaseous Diffusion Plant (PGDP) Neighborhood Council was chartered in 1992 to ". . . achieve regular and direct communication between a group of nearby residents and the plant owner and contractor in order to provide information of interest to neighbors and broaden their understanding of plant operations." Its eight members are formally appointed by the deputy plant manager, with input from current council members. Members serve staggered four-year terms, with four new members appointed every two years.

Although the Neighborhood Council has been administered through the United States Enrichment Corporation and Martin Marietta Utility Services, Inc. (MMES), since July 1, 1993, Martin Marietta Energy Systems, Inc. (MMES), Environmental Restoration and Waste Management (ERWM) still maintains a presence at the council's meetings and briefs its members regularly on ERWM projects and issues. During 1993, the council was briefed on the status of negotiations on the PGDP Federal Facilities Agreement, the Federal Facilities Compliance Act, the PGDP Water Policy, and the first Record of Decision for the northwest plume, and were given updates on a variety of other environmental restoration projects. The council provides meaningful input on these and other issues.

\section{Information Bulletins/Fact Sheets/Public Briefings}

During 1993, ERWM Public Affairs Department produced two general information bulletins on environmental issues and cleanup activities at the plant. Each bulletin was mailed to about 4000 people and agencies throughout the region. ERWM Public Affairs also published fact sheets on the PGDP Federal Facilities Agreement, the Federal Facilities Compliance Act, radiological terms, and other topics.

On April 6, 1993, a public briefing was held on a variety of environmental issues. Included on the agenda was discussion of the first Record of Decision for the northwest plume, during which comments from the public were taken. About 50 members of the public attended. One or two such briefings are planned for 1994. In addition, the Public Affairs Department has conducted availability sessions during which members of the public may drop in and speak directly with U.S. Department of Energy (DOE) and MMES officials about specific programs or topics of interest. 


\section{Environmental Advisory Committee}

The PGDP Environmental Advisory Committee was chartered in 1986 as part of a program to solicit expert and general public input on environmental issues at MMES facilities. Committee members include scientists, academics, business people, and members of the general public. The committee currently has five members who meet quarterly for an entire day and are paid a stipend, in addition to being reimbursed for travel expenses and meals.

In 1993 the committee was briefed on a wide range of issues, including those listed under "Neighborhood Council." The group provided meaningful input on several projects and has been instrumental in decision making.

\section{Earth Day}

The role of ERWM Public Affairs has grown over the years into a partnership with Heath Middle School and the West Kentucky Wildlife Management Area in planning and implementing annual Earth Day activities. A wide variety of environmental educational programs are planned each year in the management area and on DOE property. The event has been very successful and grows in scope each year.

\section{School Participation}

In addition to Earth Day activities in 1993, Public Affairs arranged a number of interactions with area schools, from providing judges for science fairs to providing speakers on a variety of environmental topics. ERWM engineers and scientists willingly participate in these activities.

\section{Awareness Programs}

In 1993 Public Affairs began developing a "minicourse" on ERWM activities and programs for new employees as well as other interested parties. In conjunction with the minicourse, the department began developing a briefing book for new employees and visitors, which gives a pictorial and narrative overview of ERWM activities. Both the minicourse and the briefing book are to be completed and in use in 1994.

\section{Public/Media Contacts}

In addition to public briefings, meetings, and availability sessions, Public Affairs personnel, along with DOE and MMES officials, visit plant neighbors regularly to hear their concerns and answer their questions firsthand. Public Affairs also deals regularly with media inquiries.

\section{WASTE MINIMIZATION/POLLUTION PREVENTION (WMPP) PROGRAM}

The WMPP Program at PGDP provides guidance and objectives for minimizing solid waste generation for disposal and discharges to the environment via air and water. Guidance for the program comes from regulations covered by the Resource Conservation and Recovery Act and the Pollution Prevention Act and from applicable state and U.S. Environmental Protection Agency rules. In addition, having a program to conserve natural resources and protect the environment is MMES policy.

\section{Program Objectives}

The PGDP Waste Minimization Program was started in 1987. The program was given additional emphasis in 1992 through creation of a full-time position for a Waste Minimization Program manager. Additional pollution prevention emphasis was incorporated in 1993. 
The WMPP Program has the following objectives:

- identifying WMPP reduction opportunities,

- establishing WMPP divisional goals,

- prioritizing WMPP efforts,

- initiating WMPP projects,

- identifying WMPP responsibilities and resource requirements, and

- tracking and reporting WMPP results.

\section{Program Organization}

The WMPP Program is administered by the Waste Minimization Program manager, who is part of the Environmental and Waste Management Division. Record keeping and reporting information is obtained through the Waste Management Operations Department, which is also part of the Environmental and Waste Management Division.

\section{Program Implementation}

In conjunction with the Environmental Policy departments and the Waste Management Operations Department, the Waste Minimization Program manager identifies waste streams that are high-priority minimization or reduction candidates based on the following factors:

- availability of storage space,

- waste stream hazard,

- availability of treatment and disposal facilities (both on- and off-site),

- regulatory compliance issues, and

- management and disposal costs.

Following identification and prioritization of projects, the project listing is divided into two categories: projects that can be accomplished with existing resources and those that require additional resources. A project team is established for each individual project and is chaired by the Waste Minimization Program manager. Project teams include members from the responsible organizations or facilities: the Technical Operations and Technical Services divisions, the Process and Long-Range Technical Support programs, and the Waste Management Operations Department. Members are included from other organizations as well when necessary.

Large projects may take the form of a formal Total Quality Management project. This is most likely to be the case when a significant investment in funding may be required or when the project could result in significant changes in facilities, systems, or operational procedures.

Following completion of the Total Quality Management or pilot project, the project team makes a recommendation to the Waste Minimization Program manager and to plant management concerning the project. Management then decides whether to fully implement the project.

\section{Program Plan FY 1993 Program Goals}

For FY 1993, each major waste-generating division was asked to submit its own waste minimization objectives as part of its production work plan. The following objectives were submitted and make up the PGDP short-term goals. 
- Develop and implement a plan to reduce the volume of packing waste materials delivered inside controlled areas.

- Prevent clean materials from entering the motor shop on wooden pallets by purchasing metal pallets for material handling in the shop. Reduce the number of wooden pallets in the shop by $25 \%$.

- Incorporate waste minimization considerations into the pre-job planning stage of the new Work Control Program.

- Eliminate C-720 degreaser wastes.

- Install an oil filter-crumbling machine for the garage, realizing a 3 to 1 waste minimization cost savings.

- Institute paint thinner recycling to minimize the waste stream.

- Investigate recycling for several waste streams. Equipment is being installed to shred and bale paper and cardboard. Fluorescent bulbs are already being sent off-site to a recycler, and a battery recycler has been approved for use.

\section{Long-Term Program Strategy}

The long-term strategy for the Waste Minimization Program includes working toward the FY 1994 goals on an ongoing basis. Several other long-term goals and strategies have also been identified.

\section{Low-Level Waste (LLW)}

The strategy for minimizing LLW includes

- establishing nonradioactive material management areas,

- preventing packaging material from entering radiological areas,

- replacing wood pallets used in radiological areas,

- compacting or incinerating combustible LLW,

- compacting noncombustible LLW,

- moving metalworking and equipment repair out of radiological areas where possible, and

- decontaminating contaminated scrap metal.

\section{Hazardous and Mixed Wastes}

Mixed waste streams are highly variable at PGDP - a large number of small-quantity waste streams exist. Major wastes include chlorinated solvents, aerosol cans, paint wastes, and laboratory wastes. The mixed waste reduction strategy includes

- establishing nonradioactive material management areas (involving reclassification of mixed wastes to hazardous wastes),

- eliminating chlorinated solvents in process buildings and shops,

- recycling paint waste, and

- replacing aerosol cans.

Although most of these projects are specific to a particular waste stream, a detailed review of all mixed waste streams will also be conducted to identify other potential minimization opportunities.

\section{Polychlorinated Biphenyl (PCB) and PCB-Radioactive Wastes}

PCB and PCB-radioactive waste generation is controlled by regulatory requirements. The most significant waste generation activities include spill cleanup, site cleanups (under the Environmental Restoration Program), and equipment removal. Little opportunity exists for waste minimization in these areas, although some

\section{3-4 Environmental Program Information}


compaction of trash may be feasible. For the foreseeable future, however, efforts will be concentrated on identifying technologies for treatment of PCB-radioactive solid wastes. Liquid PCB wastes will continue to be disposed of at the Toxic Substances Control Act incinerator in Oak Ridge, Tennessee.

\section{Residential Wastes}

Minimizing the generation of residential waste is unlikely. Increases in the plant population will result in waste increases. However, the volume of waste could be minimized through off-site recycling (of paper, cardboard, etc.) and through continued compaction of wastes before they are buried at the landfill. Off-site disposal of some residential wastes, such as food wastes, will reduce PGDP landfill use but will not be true waste minimization or reduction.

\section{Data Management}

Better data management techniques will be required to track Waste Minimization Program and waste reduction results. A method to identify causes for waste generation is essential. Currently, it is not possible to accurately differentiate between spill cleanup, site cleanup, special projects, and routinely generated wastes. Setting definitive waste minimization goals will be difficult until wastes over which PGDP has no control can be distinguished from those over which it does have control. The development of a better tracking and reporting system will take one to two years and is a long-term program goal.

\section{Environmental Training Program}

In an effort to form a "seamless" ERWM organization, PGDP and the Portsmouth Gaseous Diffusion Plant (with guidance from the K-25 Site in Oak Ridge, Tennessee) are uniting to create a formal training program.

Each site conducted an ERWM training needs assessment to identify job functions and associated training needs. The resulting baselines are being incorporated into a training plan that will serve both PGDP and the Portsmouth plant. Until the training plan is fully implemented, training coordinators at both plants are ensuring that compliance training needs are being met through various sources, including the purchase of training services from Martin Marietta Utility Services, Inc. 


\title{
4. Radiological Effluent Monitoring
}

D. W. Jones, W. D. Malis, and C. C. Travis

\begin{abstract}
Radiological effluent monitoring at Paducah Gaseous Diffusion Plant includes sampling of airborne emissions from equipment used in the gaseous diffusion process and sampling of liquid effluents at various points on the plant site. Effluents are monitored for radionuclides known to be released or that have been present at the site. Concentrations for the radionuclides measured (uranium and technetium) for both airborne and liquid effluents were within the acceptable limits set by the U.S. Department of Energy and state and federal standards.
\end{abstract}

\section{INTRODUCTION}

This section briefly describes the Paducah Gaseous Diffusion Plant (PGDP) radiological effluent monitoring programs for air and surface water. Radiological effluent measurements and estimates provide the bases for comparisons with applicable dose standards and concentrations. Dose calculations and comparisons are discussed in Section 6. Applicable regulations are discussed in the following sections on airborne and liquid effluents.

Radiological airborne effluents are determined by direct continuous sampling, intermittent sampling, or by application of U.S. Environmental Protection Agency (EPA)-approved emission factors found in Title 40, Code of Federal Regulations, Part 61 (40 CFR 61), Subpart H, Appendix D.

Monitoring of radioactivity in liquid effluents is described in the PGDP Environmental Monitoring Plan (MMES 1992a). Sampling and analytical activities are the responsibility of Martin Marietta Utility Services, Inc. The Environmental Monitoring Department, part of the Environmental and Waste Management Division, provides sampling support, and the Analytical Laboratory, part of the Technical Services Division, provides analytical measurements. Effluents are monitored for radiological species known to be emitted or that have been present at the site. Flow-proportional samplers are used for continuous-flow liquid effluent locations, and grab samples are used for intermittent (caused by rainfall) locations.

\section{AIRBORNE EFFLUENTS}

Radiological airborne effluents at PGDP are determined by three primary methods: direct continuous sampling, intermittent sampling, and use of EPA-approved emission factors. The C-310 stack, which is the effluent point for the "top" of the gaseous diffusion enrichment cascade and the C-310 product cylinder burp station, is sampled continuously. The C-335 uranium hexafluoride $\left(\mathrm{UF}_{6}\right) /$ chlorofluorocarbon (CFC)-114 separation system's effluent is sampled with the same method as the C-310 stack; however, the system is used only on an as-needed, intermittent basis. The C-360 pigtail exhausts, which are the effluent points for the hoods over the C-360 autoclave pigtail connection/disconnection activities, and the seal exhaust/wet-air exhaust stacks are sampled once every five years. All other emissions are determined or estimated based on process knowledge.

\section{Applicable Regulations}

U.S. Department of Energy (DOE) Order 5400.1, General Environmental Protection Program, requires that effluent monitoring be conducted at all DOE sites. DOE Order 5400.5, Radiation Protection of the Public and the Environment, sets annual dose standards for members of the public of 10 mrem/year from airborne releases and $100 \mathrm{mrem} / \mathrm{year}$ through all exposure pathways resulting from routine DOE operations.

Radiological airborne releases are also regulated by the EPA under 40 CFR 61, Subpart H, which covers radionuclide emissions, other than radon, from DOE facilities. This regulation was amended in 1989 to include specific sampling requirements for each emission point with the potential to emit radionuclides resulting in an effective dose equivalent of $0.1 \mathrm{mrem}$ to the most affected off-site resident. When determining potential emissions, it is assumed that any air pollution abatement devices do not exist but that the facility is otherwise operating normally. To achieve compliance with 40 CFR 61, Subpart H, PGDP entered into a federal facilities 
compliance agreement with EPA Region IV in May 1992. In March 1993, the EPA certified that PGDP was in full compliance.

\section{Monitoring Program}

\section{C-310 Stack}

Radiological emissions from the C-310 stack are determined by a continuous potassium hydroxide (KOH) bubbler sampler. The sample is extracted from the stack and passed through a series of three bubblers, each of which contains a 0.3 molar $\mathrm{KOH}$ solution. Radionuclides are effectively trapped by this solution. The primary " $A$ " bubbler is changed daily and the solution analyzed. The secondary " $\mathrm{B}$ " and " $\mathrm{C}$ " bubblers are changed monthly, and any radionuclide concentration that passes through the " $\mathrm{A}$ " bubbler is added to the monthly total. Bubbler solution analysis indicates that on average the " $A$ " bubbler captures more than $95 \%$ of the sample pollutants.

The $\mathrm{KOH}$ solution is analyzed daily for uranium concentration. The solution is also subjected to a gross beta count for ${ }^{99} \mathrm{Tc}$. Normally, not enough ${ }^{99} \mathrm{Tc}$ is collected daily to be detectable through chemical analysis; therefore, a monthly composite sample is collected, and ${ }^{99} \mathrm{Tc}$ emissions are determined by radiochemical analysis of this composite. Quarterly composites are collected and analyzed for minute quantities of ${ }^{239} \mathrm{Pu},{ }^{237} \mathrm{~Np}$, and ${ }^{230} \mathrm{Th}$. These radionuclides are present in minute quantities in the cascade because of the introduction of reactor tails as feed materials in the 1950s, 1960s, and 1970s. Emissions of these radionuclides are usually undetectable in daily or monthly samples. In 1993, measured radionuclide emissions from the $\mathrm{C}-310$ stack were $3.13 \mathrm{E}-4 \mathrm{Ci}$ $\left(1.16 \mathrm{E}-7 \mathrm{~Bq}\right.$ ) of uranium (based on $212 \mathrm{~g}$ of $2 \%$ assay), $2.56 \mathrm{E}-6 \mathrm{Ci}(9.47 \mathrm{E}-4 \mathrm{~Bq})$ of ${ }^{239} \mathrm{Pu}, 5.91 \mathrm{E}-6 \mathrm{Ci}$ $(2.19 \mathrm{E}-5 \mathrm{~Bq})$ of ${ }^{230} \mathrm{Th}$, and $3.31 \mathrm{E}-3 \mathrm{Ci}(1.22 \mathrm{E}-8 \mathrm{~Bq})$ of ${ }^{99} \mathrm{Tc}$. These emissions resulted in an effective dose equivalent of $3.6 \mathrm{E}-4$ mrem to the most affected off-site resident.

This continuous sampling system employs a different methodology than is usually used to sample for radionuclides. Most radionuclide emissions are in the form of particulates. The inherent operational properties of the enrichment cascade result in gaseous emissions at the point of sampling. The EPA required PGDP to perform particulate sampling in 1992 to confirm that there were no radionuclide particulates at the point of sampling and subsequently approved the stack sampling methodology.

EPA rule 40 CFR 61, Subpart $H$, allows sources with radionuclide emissions that would not cause a dose greater than 0.1 mrem to the most affected off-site resident to be sampled by methods other than continuous stack sampling. Furthermore, emissions from such minor sources may be grouped. The following is a discussion of the grouped, minor radionuclide sources at PGDP.

\section{C-360, C-315, and C-310 Pigtail Exhausts}

The C-360 building is used to sample feed before it is introduced into the gaseous diffusion cascade and to sample product cylinders before shipment to the Portsmouth Gaseous Diffusion Plant. The cylinders are heated in an autoclave, and the sample is extracted via a "pigtail." A pigtail is a length of copper tubing connected to the cylinder valve. The C-310 building is used to withdraw enriched product from the "top" of the gaseous diffusion cascade. The C-315 building is used to withdraw "tails," or depleted uranium, from the "bottom" of the gaseous diffusion cascade. The enriched product and tails are both withdrawn through pigtails.

The potential for emissions from these activities occurs when the pigtail is disconnected from the cylinder. Although procedures require that the pigtails go through a series of double purges to sweep out any $\mathrm{UF}_{6}$, occasionally a "whiff or puff" of UF $_{6}$ is emitted when the pigtail is disconnected. The purpose of the pigtail exhaust system is to capture any whiff or puff and exhaust it through a high-efficiency particulate air (HEPA)filtered stack. PGDP also recently began using a portable, hand-held HEPA vacuum to further reduce any potential emissions. The C-360 pigtail exhaust system was sampled via EPA-approved methods during operation of the autoclaves in 1992. Results of the analyses indicated that the emissions were so insignificant that they could not be statistically distinguished from zero. The pigtail exhausts are scheduled to be resampled in 1997 to confirm these low emission rates.

\section{4-2 Radiological Effluent Monitoring}




\section{Seal Exhausts and Wet-Air Exhausts}

Seal exhausts service the $\mathrm{UF}_{6}$ compressor seals in the gaseous diffusion cascade. These seals are supplied with an intricate array of air pressures to reduce any $\mathrm{UF}_{6}$ emissions that might occur from a seal failure. Under normal operations, there is no $\mathrm{UF}_{6}$ in the seal exhaust stream. However, in some instances, minute amounts of $\mathrm{UF}_{6}$ can bypass the seal and enter the exhaust stream. This $\mathrm{UF}_{6}$ must pass through an alumina trap scrubber with a high affinity for $\mathrm{UF}_{6}$ before reaching the seal exhaust pump. Any $\mathrm{UF}_{6}$ that passes through the alumina must then pass through the pump oil, another excellent $\mathrm{UF}_{6}$ trapping material, before being emitted to the atmosphere. The primary purpose of the alumina traps is to protect the pump oil from any $\mathrm{UF}_{6}$ in the exhaust stream because $\mathrm{UF}_{6}$ reacts quickly with the pump oil to form a thick sludge that causes the pumps to trip.

During maintenance on a section of the gaseous diffusion cascade, $\mathrm{UF}_{6}$ is evacuated to other areas of the cascade. The section of the cascade to be opened for maintenance is swept with purging gases to remove any residual $\mathrm{UF}_{6}$. The system is closed after maintenance, and the ambient "wet air" is removed before $\mathrm{UF}_{6}$ is reintroduced. The purging gases and the wet air are both exhausted through the wet-air exhaust stacks. In most buildings, the seal exhaust and the wet-air exhaust discharge through the same stack. In 1992 stack sampling by EPA methods was performed on one seal exhaust stack, one wet-air exhaust stack, and one seal exhaust/wet-air combined stack. The only detectable emissions were minute quantities of uranium and plutonium. When multiplied by the number of stacks present and assuming a continuous emission, these emissions totaled only $2.6 \mathrm{E}-5 \mathrm{Ci}$ of uranium and $2.26 \mathrm{E}-6 \mathrm{Ci}$ of plutonium per year. The dose from the emissions was $1.3 \mathrm{E}-4 \mathrm{mrem}$ to the most affected off-site resident. These stacks are scheduled to be resampled in 1997.

\section{Other Grouped, Minor Radionuclide Emission Points}

PGDP has several other minor emission points from which radionuclide emissions are estimated by the procedures outlined in Appendix D to $40 \mathrm{CFR}$ 61, Subpart H. Appendix D allows estimation of the number of curies "used" at a source, followed by application of specified emission factors based on the physical form (gas, particulate, or solid) of the material subject to emission. Pollution abatement factors are also specified in Appendix D. PGDP uses Appendix D to estimate radionuclide emissions for the following sources:

- C-400 decontamination activities,

- C-720 motor burnout ovens,

- C-710 and C-409 laboratory hoods, and

- cylinder valve (pigtail) connection activities not serviced by a dedicated exhaust system.

The 1993 radionuclide emissions estimated from these minor emission points were $8.45 \mathrm{E}-4 \mathrm{Ci}(3.13 \mathrm{E}-7 \mathrm{~Bq})$ of uranium, $4.06 \mathrm{E}-8 \mathrm{Ci}(1.50 \mathrm{E}-3 \mathrm{~Bq})$ of ${ }^{237} \mathrm{~Np}, 3.82 \mathrm{E}-8 \mathrm{Ci}(1.41 \mathrm{E}-3 \mathrm{~Bq})$ of ${ }^{239} \mathrm{Pu}, 2.75 \mathrm{E}-7 \mathrm{Ci}(1.02 \mathrm{E}-4 \mathrm{~Bq})$ of ${ }^{230} \mathrm{Th}$, and $4.18 \mathrm{E}-6 \mathrm{Ci}(1.55 \mathrm{E}-5 \mathrm{~Bq})$ of ${ }^{99} \mathrm{Tc}$. These emissions resulted in an effective dose equivalent of $1.8 \mathrm{E}-3 \mathrm{mrem}$ to the most affected off-site resident.

\section{Laboratory Analysis}

The PGDP Technical Services Division provides sample analysis for the continuous C-310 stack sampler. Intermittent stack sampling on the C-360 pigtail exhausts, wet-air exhausts, and seal exhausts is usually provided by a subcontractor; however, the Technical Services Division usually performs the sample analysis.

\section{Effluent and Sample Flow Rates}

The effluent flow rate of the C-310 stack is monitored continuously by a pitot-venturi flow element. The flow element measures the average flow, and the readings are recorded and checked daily. The flow element calibration is confirmed annually by a direct velocity traverse. About $99 \%$ of the effluent flow from the C-310 stack is caused by dry plant air that exits from a jet and is used to pull a vacuum on the enrichment cascade; 
only about $1 \%$ of the effluent flow is caused by effluents from the cascade and the burp station. The total flow from the C-310 stack is about $29.4 \mathrm{~m}^{3} /$ minute $\left(1050 \mathrm{ft}^{3} /\right.$ minute).

The sample flow from the C-310 stack is measured by a thermal mass flowmeter and is provided by a diaphragm pump downstream of the bubbler cabinet. The sample flow is about $4 \mathrm{~L} /$ minute $(4.2 \mathrm{qt} / \mathrm{minute})$.

\section{LIQUID EFFLUENTS}

In addition to radiological parameters on the Kentucky Pollutant Discharge Elimination System (KPDES) permit, specific radionuclide analysis and indicator gross activity analyses are conducted on liquid effluent samples. Four locations have continuous, flow-proportional samplers to measure continuously flowing effluents. At eight other locations with intermittent flows, grab samples at various frequencies are used to measure discharges (MMES 1992a). These locations are shown in Fig. 4.1. Locations 004, 006, and 014 are not included in this program because there is little potential for radiological discharges at those points or because discharges at those locations flow through a monitored outfall. As shown in Table 7.1 in Section 7, outfalls 006 and 014 receive or discharge Ohio River water, which does not enter a facility with radiological materials. Location 004 discharges through outfall 008, which is monitored. Locations 003 and 005 do not discharge.

\section{ORNL-DWG 87M-6710R3}

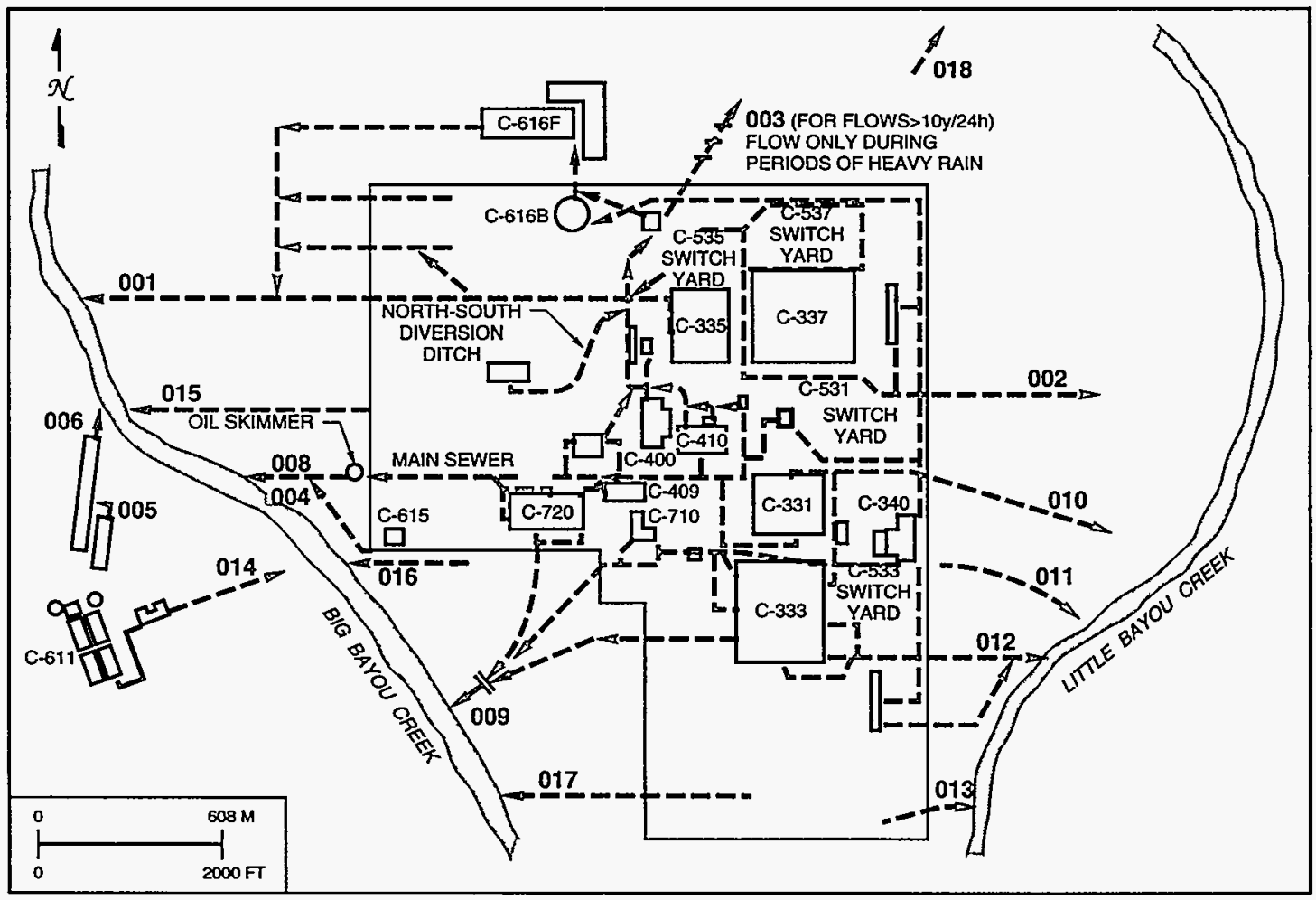

Fig. 4.1. KPDES outfall locations at PGDP.

\section{Applicable Regulations}

DOE orders 5400.1 and 5400.5 and the regulatory guide define effluent monitoring requirements to provide confidence that limits are not exceeded. Although no specific effluent limits for radiological parameters are included on the KPDES permit, DOE Order 5400.5 sets guidelines for allowable concentrations of radiological species in various effluents and requires radiological monitoring to protect public health. This protection is achieved at PGDP by meeting the DOE Order 5400.5 derived concentration guideline (DCG), which is the concentration of a given radionuclide that would result in an effective dose equivalent of $100 \mathrm{mrem} / \mathrm{year}$. The guidelines are based on the assumption that a member of the public has continuous, direct access to the liquid effluents and consumes $2 \mathrm{~L}$ of effluent every day, 365 days/year, which is a conservative exposure scenario. Safe 
Table 4.2. Radionuclide concentrations in effluents for 1993 Uranium $^{a}$

\begin{tabular}{|c|c|c|c|c|c|c|c|}
\hline \multirow[t]{2}{*}{ Location $^{b}$} & \multirow{2}{*}{$\begin{array}{l}\text { No. of } \\
\text { samples }\end{array}$} & \multicolumn{4}{|c|}{ Concentration } & \multirow{2}{*}{$\begin{array}{c}\text { wt. \% } \\
{ }^{235} \mathrm{U} \text { Av } \\
\text { (mg/L) }\end{array}$} & \multirow[t]{2}{*}{$\begin{array}{l}\text { Percentage } \\
\text { of } D^{-} G^{c}\end{array}$} \\
\hline & & $\operatorname{Max}$ & Min & $\mathrm{Av}$ & $\mathrm{Av}$ & & \\
\hline K001 & 76 & 0.2 & 0.002 & 0.0326 & 19 & 0.5653 & 3 \\
\hline K002 & 7 & 0.004 & $<0.001$ & $<0.0021$ & 13 & 0.6 & 2 \\
\hline K008 & 13 & 0.019 & 0.001 & 0.008 & 5 & 0.5913 & 0.8 \\
\hline K009 & 13 & 0.006 & $<0.001$ & $<0.0026$ & 1.5 & 0.3810 & 0.2 \\
\hline K010 & 11 & 0.036 & 0.008 & 0.0213 & 10 & 0.33 & 2 \\
\hline K011 & 54 & 0.074 & 0.004 & 0.033 & 15 & 0.2653 & 3 \\
\hline K012 & 8 & 0.009 & 0.004 & 0.0055 & 4 & 0.6618 & 0.6 \\
\hline K013 & 5 & 0.004 & 0.001 & 0.0028 & 1.3 & 0.2 & 0.2 \\
\hline K015 & 8 & 1 & 0.02 & 0.2013 & 97 & 0.3123 & 16 \\
\hline K016 & 4 & 0.016 & 0.001 & 0.0083 & 5 & 0.5060 & 0.8 \\
\hline K017 & 4 & 0.01 & 0.004 & 0.0073 & 4 & 0.5163 & 0.7 \\
\hline K018 & 6 & 0.023 & 0.003 & 0.0102 & 0.7 & 0.6893 & 1 \\
\hline
\end{tabular}

${ }^{a}$ See Appendix $\mathrm{C}$ for half-life information.

${ }^{b}$ See Fig. 4.1.

'DCG for total uranium is $600 \mathrm{pCi} / \mathrm{L}$.

Table 4.3. Radionuclide concentrations in effluents for 1993

\begin{tabular}{|c|c|c|c|c|c|c|}
\hline \multirow{3}{*}{ Location $^{b}$} & \multirow{3}{*}{$\begin{array}{l}\text { No. of } \\
\text { samples }\end{array}$} & \multicolumn{4}{|c|}{ Concentration } & \multirow{3}{*}{$\begin{array}{l}\text { Percentage } \\
\text { of } D_{C G^{c}}\end{array}$} \\
\hline & & \multicolumn{3}{|c|}{$(\mathrm{pCi} / \mathrm{L})$} & $(\mathrm{Bq} / \mathrm{L})$ & \\
\hline & & $\operatorname{Max}$ & Min & Av & $\mathrm{Av}$ & \\
\hline K001 & 56 & 99 & 2 & 28.75 & 1.06 & 0.03 \\
\hline $\mathrm{K} 002$ & 5 & 17 & 6 & 10.4 & 0.385 & 0.01 \\
\hline K008 & 6 & 37 & 7 & 18 & 0.666 & 0.02 \\
\hline K009 & 6 & 26 & 7 & 17 & 0.629 & 0.02 \\
\hline K010 & 11 & 116 & 0 & 37.8 & 1.40 & 0.04 \\
\hline K011 & 54 & 32 & $<0$ & $<9.80$ & $<0.362$ & $<0.01$ \\
\hline K012 & 7 & 24 & 0 & 9.86 & 0.365 & 0.01 \\
\hline K013 & 2 & 25 & 6 & 15.5 & 0.574 & 0.015 \\
\hline K015 & 3 & 50 & 28 & 36.3 & 1.34 & 0.04 \\
\hline K016 & 1 & 5 & 5 & 5 & 0.185 & 0.01 \\
\hline K017 & 1 & 6 & 6 & 6 & 0.222 & 0.01 \\
\hline K018 & 3 & 61 & 24 & 37.7 & 1.39 & 0.04 \\
\hline
\end{tabular}

${ }^{a}$ See Appendix $\mathrm{C}$ for half-life information.

${ }^{b}$ See Fig. 4.1.

DCG for ${ }^{99} \mathrm{Tc}$ is $100,000 \mathrm{pCi} / \mathrm{L}$. 
ORNL-DWG 93M-12572

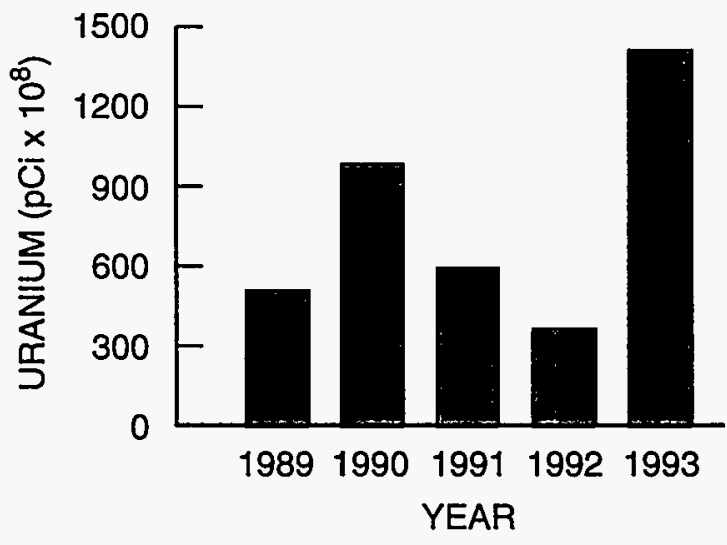

Fig. 4.3. Uranium discharges to surface water, 1989-1993. The elevated estimate for 1993 was the result of very high instantaneous flow readings caused by heavy rainfall on the sampling date. To convert activity in picocuries to mass in kilograms, divide by $5.41 \times 10^{8}$ using an average assay of $0.4283 \mathrm{wt}$. \% ${ }^{235} \mathrm{U}$.

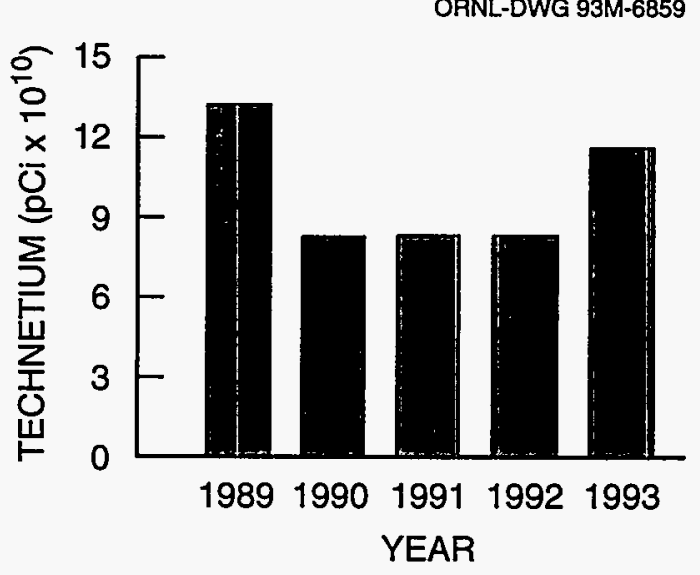

Fig. 4.4. Technetium-99 discharges to surface water, 1989-1993. To convert activity in picocuries to mass in grams, divide by $1.685 \times 10^{10}$.

Although the estimated totals have changed from previous years, there is little change in DCG estimates (shown in Tables 4.2 and 4.3 ) compared to previous years, which indicates that there is little change in the risk to humans.

Data comparisons were made using a one-tailed t-test at $95 \%$ confidence level for radiological results comparing each landfill location, SW45 and SW46, with reference or background data taken at Big Bayou Creek (SW1). In all instances, a problem is indicated if there is an increase over natural background. Statistically, uranium was significantly elevated at both SW45 and SW46. Gross beta was elevated at SW45. However, these locations are directly on the landfill proper. Rainfall runoff from these locations flows through KPDES outfall 018 to Little Bayou Creek, where radiological environmental surveillance is conducted. 


\title{
5. Radiological Environmental Surveillance
}

\author{
W. D. Malis, R. C. Summers, and M. G. White
}

\begin{abstract}
The purpose of the radiological environmental surveillance program at Paducah Gaseous Diffusion Plant (PGDP) is to assess the effects of PGDP operations on the site and the local environment and population. Surveillance includes analysis of air, surface water, groundwater (see Section 9), sediment, soil, food crops, and wildlife. Surveillance results indicate that radionuclide concentrations in most sampled media were within applicable standards. Direct radiation is also measured, and results indicate that gamma radiation levels at and beyond the plant perimeter have not increased significantly over time.
\end{abstract}

The radiological environmental surveillance program at Paducah Gaseous Diffusion Plant (PGDP) is designed to survey and quantify any effects routine and nonroutine operations may have on the site, the surroundings, and the local population. As part of the radiological environmental surveillance program, routine monitoring of radiation exposure pathways is performed on environmental media that may lead to a measurable annual dose at the site boundary. Surveillance includes analyses of air, surface water, groundwater (see Section 9), sediment, soil, vegetation, food crops, and wildlife. Direct radiation is also measured.

The radiological environmental surveillance program is driven by U.S. Department of Energy (DOE) and U.S. Environmental Protection Agency requirements. DOE orders 5400.1, General Environmental Protection Program, and 5400.5, Radiation Protection of the Public and the Environment, require that an environmental surveillance program be established at all DOE sites to monitor the effects, if any, of DOE activities on the surrounding population and environment.

\section{AMBIENT AIR}

PGDP maintains and operates an ambient air monitoring system to assess the impact of radioactive particulates emitted by PGDP on the surrounding environment and population.

\section{Surveillance Program}

Ambient air is sampled continuously for radioactive particulates at the following locations:

- $\quad$ plant north (PN), plant south (PS), plant east (PE), and plant west (PW) within the plant fence;

- boundary north (BN) and boundary east (BE) at the plant boundary;

- one north (1N), one south (1S), one west (1W), one east (1E), and one southeast (1SE) at 1 mile from the plant fence; and

- Grahamville (GR), the nearest community.

Figure 5.1 shows these locations.

The sample collectors are exchanged and analyzed each week for alpha and beta activity. To ensure data accuracy, samples are not analyzed if a problem occurs causing the final sample flow to decrease more than $40 \%$ from the initial flow rate or if the sampler is found not running. In addition, analysis is not performed if upon opening the filter holder the analyst finds the filter cracked (Coker 1988). After the sample filters have been collected from the ambient air monitoring stations, they are stored for at least 168 hours to permit decay of the short-lived daughters of naturally occurring radon and thorium. Samples are then analyzed for alpha and beta activity by an automatic low-background alpha/beta proportional counter (PGDP 1990).

In response to the 1990 Tiger Team assessment, PGDP has proposed some improvements in the ambient air monitoring program. An ambient air monitoring plan has been developed to implement these improvements to the monitoring system. An engineering project recommending purchase and installation of new high-volume monitoring equipment has been approved, and the new equipment is being installed. 
ORNL-DWG 87M-6712FR

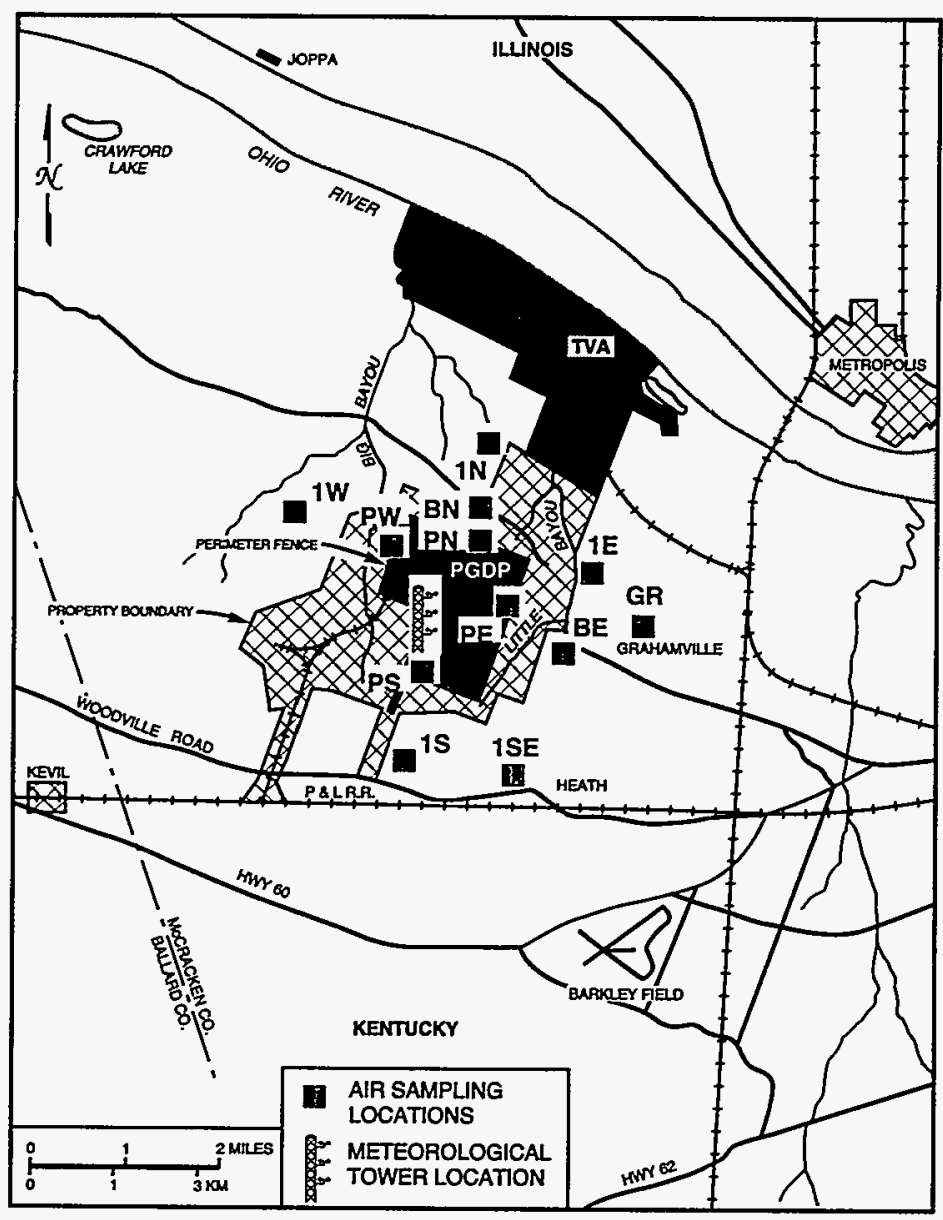

Fig. 5.1. Air sampling and meteorological monitoring stations at

\section{Surveillance Results}

Table 5.1 provides a summary of the 1993 ambient air measurements. The highest average gross alpha count was found at plant north $\left(0.58 \times 10^{-14} \mu \mathrm{Ci} / \mathrm{mL}\right.$, $2.15 \times 10^{-10} \mathrm{~Bq} / \mathrm{mL}$ ), and the highest average gross beta count was found at boundary north $\left(0.31 \times 10^{-13} \mu \mathrm{Ci} / \mathrm{mL}, 1.5 \times\right.$ $10^{-9} \mathrm{~Bq} / \mathrm{mL}$ ). The maximum weekly gross alpha count was found at plant south $\left(2.85 \times 10^{-14} \mu \mathrm{Ci} / \mathrm{mL}\right.$, $1.05 \times 10^{-9} \mathrm{~Bq} / \mathrm{mL}$ ), and the maximum weekly gross beta count was found at plant north $\left(1.33 \times 10^{-13} \mu \mathrm{Ci} / \mathrm{mL}, 4.92 \times\right.$ $\left.10^{-9} \mathrm{~Bq} / \mathrm{mL}\right)$.

A comparison using a t-test at 95\% confidence level of prevailing upwind locations (1S, PS, 1SE, 1W, and $\mathrm{PW}$ ) to prevailing downwind locations showed no significant difference in gross alpha data. One location, PN, was significantly different from the rest of the numbers, indicating that plant air emissions were impacting that location. Gross beta was compared in the same way. This comparison showed a significantly higher gross beta in the downwind data at $95 \%$ confidence level.

\section{Meteorological Monitoring}

DOE Order 5400.1 requires that DOE facilities collect representative meteorological data in support of environmental monitoring activities. This information is essential to characterize atmospheric transport and diffusion conditions in the vicinity of PGDP and to represent other meteorological conditions (e.g., precipitation, temperature, and atmospheric moisture) that are important to environmental surveillance activities such as air quality and radiation monitoring.

On-site meteorological data are used to calculate radiation doses to the public (see Section 6). In addition, on-site meteorological data are used by various groups within the plant, for example, by Environmental Restoration to correlate precipitation with groundwater flow and by Power Operations to investigate electrical equipment failures.

A $60-\mathrm{m}$ tower, located south of the $\mathrm{C}-100$ administration building, contains instrumentation at heights of 10 and $60 \mathrm{~m}$ (32.8 and $196.9 \mathrm{ft}$ ). Appropriate meteorological parameters such as wind speed and direction, temperature, barometric pressure, relative humidity, and rainfall are monitored to provide valuable data on atmospheric stability as well as other data essential to reliable atmospheric dispersion modeling. Because the tower was out of service for part of the year, wind speed frequency data were insufficient to generate an accurate wind rose. Therefore, Figs. 5.2 and 5.3 show the wind roses generated by the 1992 data.

Computer-aided atmospheric dispersion modeling uses emission and meteorological data to determine the impacts of plant operations. Modeling is used to simulate the transport of air contaminants and to predict the 
Table 5.1. PGDP environmental air sampling for radioactivity in 1993

\begin{tabular}{|c|c|c|c|c|c|c|c|}
\hline \multirow[t]{2}{*}{ Point ${ }^{a}$} & \multirow{2}{*}{ Count } & \multicolumn{3}{|c|}{$\begin{array}{c}\text { Gross alpha } \\
\left(\mu \mathrm{Ci} / \mathrm{mL} \times 10^{-14}\right)^{b}\end{array}$} & \multicolumn{3}{|c|}{$\begin{array}{c}\text { Gross beta } \\
\left(\mu \mathrm{Ci} / \mathrm{mL} \times 10^{-13}\right)^{b}\end{array}$} \\
\hline & & Min & $\operatorname{Max}$ & $\mathrm{Av}$ & Min & $\operatorname{Max}$ & $\mathrm{Av}$ \\
\hline PN & 53 & $-0.42^{c}$ & 0.20 & 0.58 & 0.00 & 1.33 & 0.29 \\
\hline $\mathrm{PE}$ & 47 & -0.70 & 0.74 & 0.18 & 0.00 & 0.92 & 0.28 \\
\hline PS & 52 & -0.90 & 2.85 & 0.25 & -0.26 & 0.86 & 0.26 \\
\hline PW & 53 & -0.57 & 1.61 & 0.16 & 0.00 & 0.98 & 0.26 \\
\hline BN & 51 & -0.44 & 1.26 & 0.20 & 0.00 & 1.19 & 0.31 \\
\hline $\mathrm{BE}$ & 48 & -0.58 & 2.51 & 0.18 & -0.01 & 0.76 & 0.25 \\
\hline $1 \mathrm{~N}$ & 49 & -0.45 & 1.44 & 0.17 & 0.00 & 1.10 & 0.29 \\
\hline $1 E$ & 51 & -0.34 & 1.76 & 0.22 & 0.00 & 0.83 & 0.29 \\
\hline $1 \mathrm{SE}$ & 52 & -0.45 & 1.01 & 0.16 & 0.00 & 1.00 & 0.25 \\
\hline $1 \mathrm{~S}$ & 51 & -0.44 & 1.33 & 0.17 & 0.00 & 0.71 & 0.26 \\
\hline $1 \mathrm{~W}$ & 51 & -0.50 & 1.37 & 0.15 & -0.35 & 0.82 & 0.28 \\
\hline GR & 51 & -0.37 & 1.84 & 0.23 & -0.01 & 1.06 & 0.30 \\
\hline
\end{tabular}

${ }^{a}$ See Fig. 5.1.

${ }^{b} 1 \mu \mathrm{Ci} / \mathrm{mL}=3.7 \times 10^{-8} \mathrm{~Bq} / \mathrm{mL}$.

Because of fluctuation in the instrument used to analyze for radioactivity, the background count is higher than that of the sample; this accounts for the negative numbers.

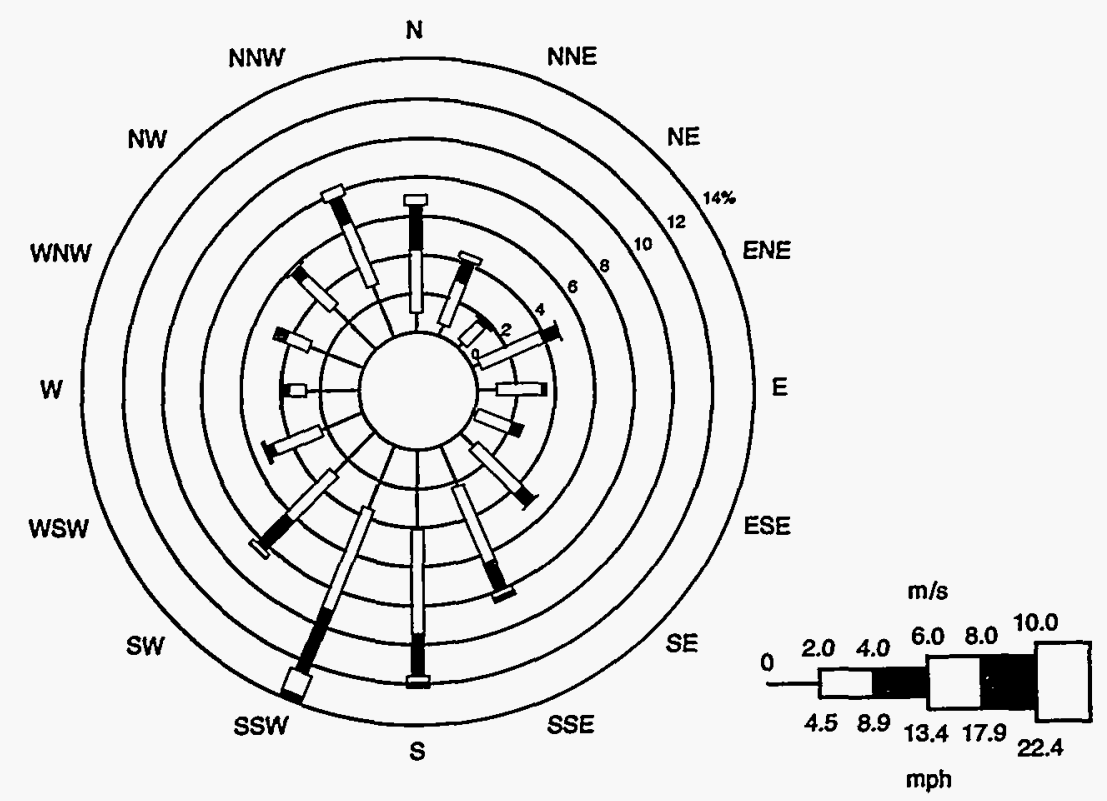

Fig. 5.2. Wind rose (10-m level) showing the wind speed frequency distribution data (with $\mathbf{9 3 . 1 \%}$ of possible data) used for the 1992 estimates. (Data for 1993 not available.) effects of abnormal airborne emissions from a given source. In addition, PGDP can postulate a multitude of emergency scenarios and estimate effects of unplanned releases on employees and population centers downwind of the source. PGDP uses the Hazardous Atmospheric Release Model II computer program for predicting off-site concentrations of unplanned heavy-gas releases.

\section{EXTERNAL GAMMA RADIATION MONITORING}

One of the potential exposure pathways for populations living within the vicinity of DOE facilities is external radiation. Dose rates from penetrating radiation (gamma rays) were measured at a number of locations in the PGDP environs during 1993. Long-term measurements were made using thermoluminescent dosimeters (TLDs). Instantaneous dose rates were also measured with hand-held meters during radiation surveys 


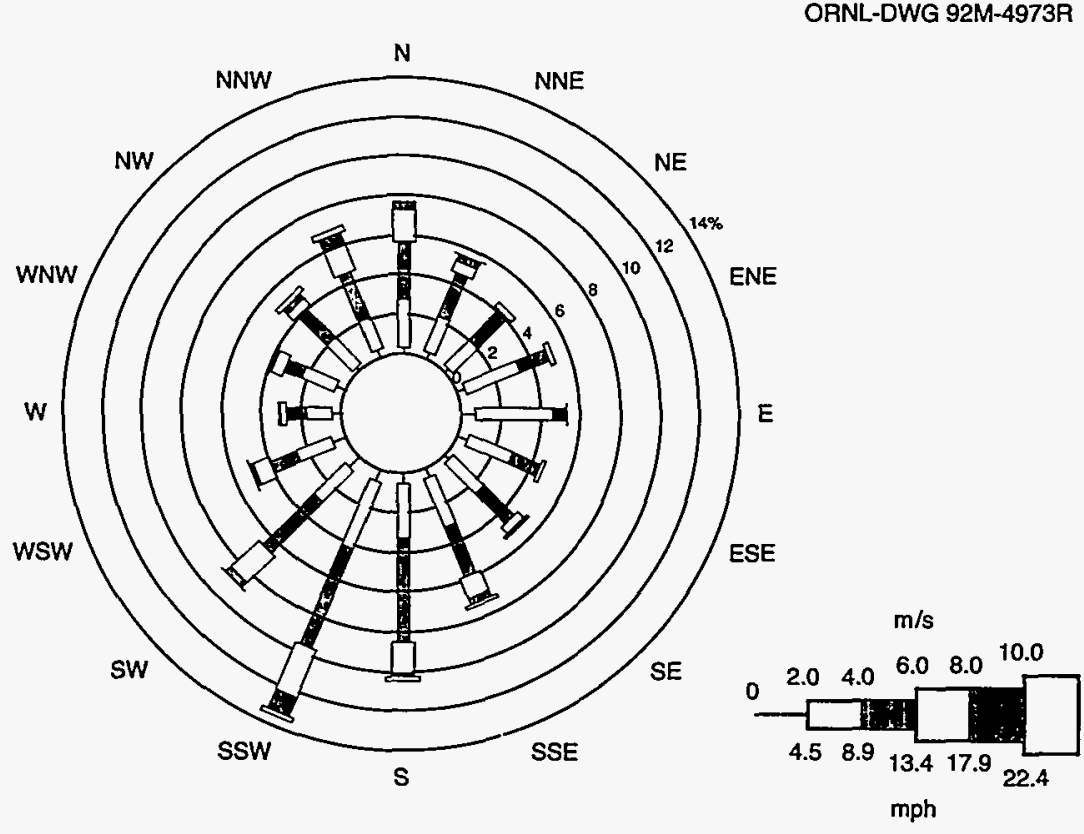

Fig. 5.3. Wind rose $(60-\mathrm{m}$ level) showing the wind speed frequency distribution data (with $93.1 \%$ of possible data) used for the 1992 estimates. (Data for 1993 not available.)

conducted at numerous locations on and around the PGDP site.

\section{TLD Monitoring Program}

During 1993 TLDs were placed in the environment to obtain data on external gamma radiation. These TLDs react to gamma and neutron radiation and, to some extent, to cosmic radiation. Fifteen monitoring dosimeters were in use during 1993. Figure 5.4 shows the locations of the TLDs. Ten quality control TLDs were also in use during each quarter; Fig. 5.5 shows their locations.

The external gamma radiation program is conducted using guidance from American National Standards Institute Standard N545-1975. The TLDs are identified, annealed, calibrated, packaged, and shipped by Oak

Ridge National Laboratory (ORNL). When they arrive at PGDP, they are promptly positioned in the PGDP environment about $1 \mathrm{~m}(3 \mathrm{ft})$ above the ground. The TLD packages are placed in four types of locations: along the plant perimeter fence, at the reservation boundary, at nearby residences or communities, and at two background locations more distant from the site. After the quarterly exposure period, the TLDs are collected and returned to ORNL for exposure determination.

Although the TLD exposures were measured in microroentgens per hour $(\mu \mathrm{R} / \mathrm{hour})$, measured doses are also reported in dose equivalent units (millirems) to allow comparison with dose standards and dose equivalents reported elsewhere in this document. To convert to millirems per year, some exposure period must be assumed. To allow for comparison, continuous exposure has been assumed at all locations. In reality, exposure will vary depending on public access to a particular location. Table 5.2 shows the average exposure rates above background for each TLD location. Table 5.3 lists quality control data for the TLDs. The mean exposure rate above background for indicator locations as measured by the TLDs (excluding perimeter fence data) is about $5.0 \mu \mathrm{R} /$ hour. When that rate is compared with the mean of four background exposure rates, the indicator locations are significantly lower at the $95 \%$ confidence level. Assuming continuous exposure at this level ( $5.0 \mu \mathrm{R} /$ hour), the external whole body dose would be about $44 \mathrm{mrem} / \mathrm{year}(0.44 \mathrm{mSv} / \mathrm{year})$. This number corresponds to the average external whole body dose estimated to be received by people throughout Kentucky and Tennessee, which is between 60 and $70 \mathrm{mrem} / \mathrm{year}(0.60$ to $0.70 \mathrm{mSv} / \mathrm{year}$ ) (Klement et al. 1972). Dose rates at the plant perimeter were somewhat higher than background rates. The higher exposure rates at locations near the perimeter fence are attributed to direct radiation from the uranium cylinder storage and handling areas. Although the rates are elevated, these areas have only limited access and actually allow for very low exposure periods.

Because of the extremely small amounts of gamma radiation emitted by PGDP compared with natural background radiation, accurate measurements using TLDs are difficult to obtain. Therefore, the exposure rates measured above background by the TLD system during 1993 have a high level of uncertainty. However, the data indicate that levels of gamma radiation both at and beyond the plant perimeter have not increased significantly over time. Figure 5.6 compares the trend for external gamma radiation over a five-year period at each location. The radiation fields surrounding the cylinder storage yard are also somewhat static. The decrease in measured radiation for location 2 (see Fig. 5.6) was a result of moving cylinders from the storage yard and replacing them with new, empty cylinders. Two data points are missing for 1993. The second-quarter result for location 2 was

\section{5-4 Radiological Environmental Surveillance}


ORNL-DWG 89M-6360R2

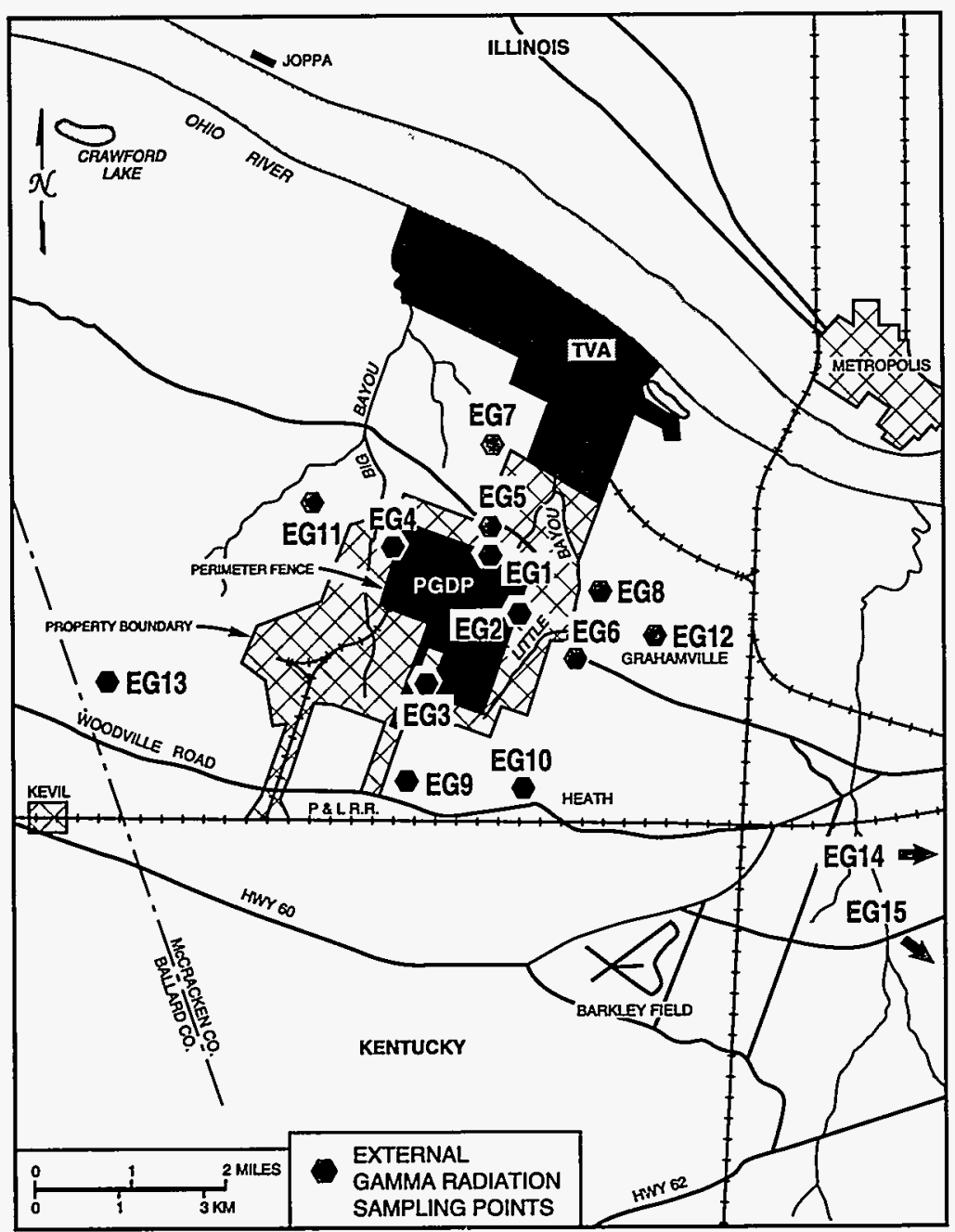

Fig. 5.4. Thermoluminescent dosimeter locations at PGDP. lost when a storm destroyed the power pole the TLD was mounted on; the TLD was never recovered. The other missing data point resulted from a field and analytical data error. The fourth-quarter TLD number for location 7 recorded by monitoring technicians did not appear on the list of analytical results from ORNL. Because this could not be resolved, the data point was eliminated and an average of three measurements was used.

\section{SURFACE WATER}

Monthly sampling is conducted at upstream Big Bayou Creek (SW1), downstream Big Bayou Creek (SW5), downstream Little Bayou Creek (SW10), upstream Ohio River (SW29), and downstream Ohio River (SW30). Background water quality is sampled at Big Bayou Creek location SW1. Figure 5.7 depicts sampling locations. Table 5.4 shows all analyses and frequencies for radiological surveillance.

Data comparisons were made using a one-tailed t-test at $95 \%$ confidence level for radiological results comparing downstream Big Bayou (SW5) and Little Bayou (SW10) creeks to reference, or background, data taken at upstream

Big Bayou Creek (SW1). The only exception was for assay, or weight percent, ${ }^{235} \mathrm{U}$, which was made using a two-tailed t-test at $95 \%$ confidence level. In all instances except for ${ }^{235} \mathrm{U}$, a problem is indicated if there is an increase over natural background. Uranium-235 being present on the site at both enriched and depleted assays may affect the creeks by raising or lowering the background assay.

Statistically, the data show significantly elevated levels of gross alpha, gross beta, and uranium at downstream location SW10. SW5 was elevated for gross alpha, gross beta, uranium, and ${ }^{99}$ Tc. The alpha activity and part of the beta activity at SW10 and SW5 are most likely related to the elevated uranium levels in Little and Big Bayou creeks, which reflect plant discharges in effluents. Additional indications of plant influence can be found in the lower ${ }^{235} \mathrm{U}$ results (statistically significant) at SW5 and SW10, which indicate that the uranium in the creek is tails (lower than normal) assay material. The additional beta activity at SW5 and SW10 is most likely related to ${ }^{99} \mathrm{Tc}$ in plant discharges to Big Bayou Creek. No measurement for 1993 gross alpha or gross beta indicated that the derived concentration guidelines were approached for uranium and ${ }^{99}$ Tc. During 1992 SW5 was elevated for gross beta and SW10 was elevated for gross alpha, uranium, and ${ }^{235} \mathrm{U}$.

Two locations on the Ohio River, SW29 and SW30, are monitored monthly for the parameters listed in Table 5.4. These results do not undergo statistical evaluation because PGDP is one of many contributors to the Ohio River. Additionally, samples are collected from the bank of the river and are not truly representative of the entire river channel. 
ORNL-DWG 89M-6361R2

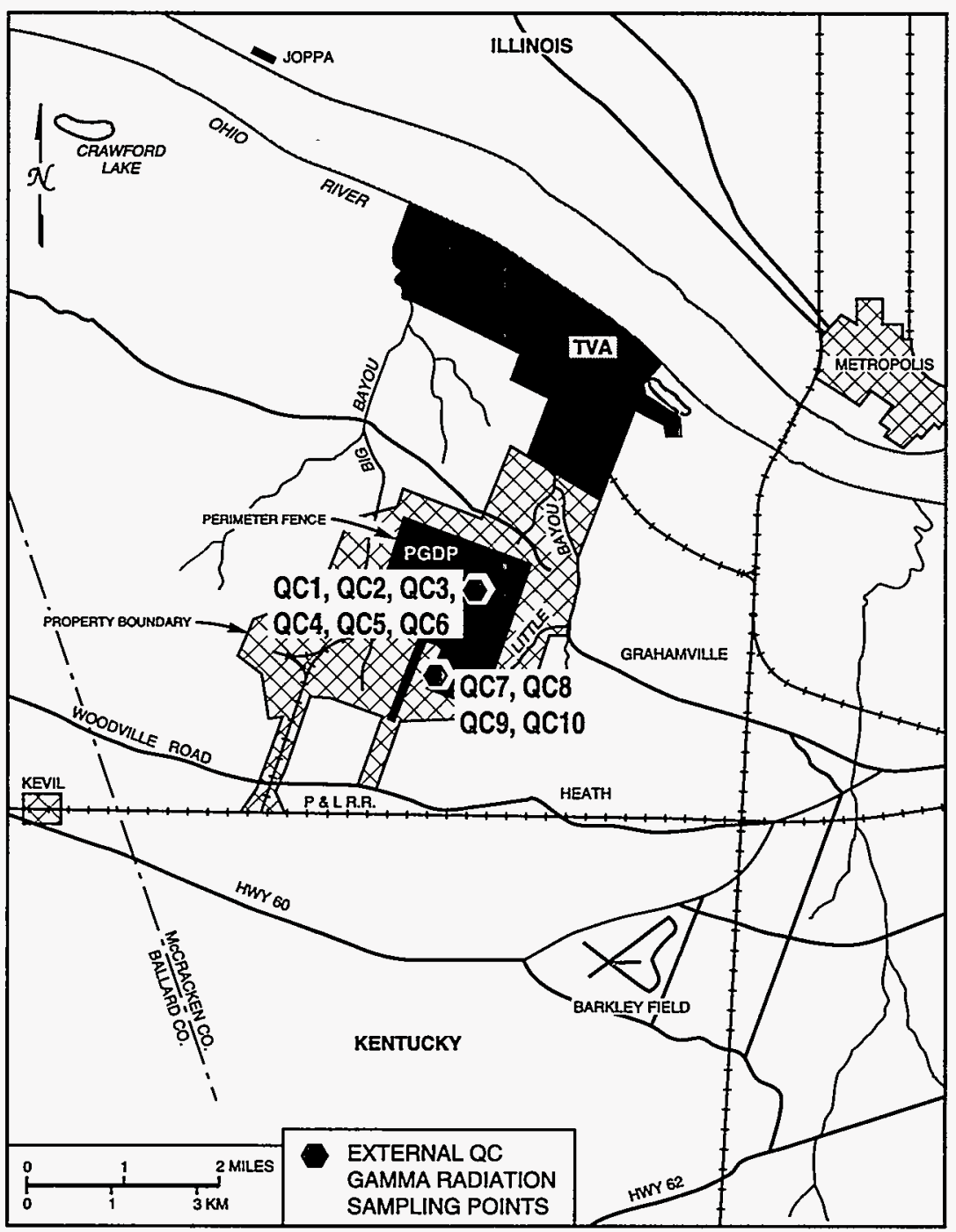

Fig. 5.5. Quality control thermoluminescent dosimeter locations at PGDP.
SW13, the north/south diversion ditch (see Fig. 5.7), is monitored weekly. This ditch receives coal-pile runoff and the C-400 decontamination solution filtrate. Grab samples were analyzed for the weekly parameters listed in Table 5.4. Each week a $100-\mathrm{mL}$ sample is poured into a yearly composite container. At the end of each year, the composite sample is analyzed for the annual parameters listed in Table 5.4. These data are used to provide a surveillance point for the ultimate discharge location in case elevated radionuclide levels are detected. Data from this location do not undergo statistical evaluation because SW13 is an internal monitoring point and ultimately flows through KPDES outfall 001 where extensive monitoring occurs.

\section{SEDIMENT}

The stream bottom is an important constituent of the aquatic environment. If a pollutant is a suspended solid or attached to suspended sediment, it can settle to the bottom (thus creating the need for sediment sampling), be filtered by certain organisms, or become attached to plant surfaces. Pollutants in solution can adsorb on suspended organic and inorganic solids or be assimilated by plants and animals. The suspended solids, dead biota, or excreta settle to the bottom and

become part of the organic substrata that support the bottom-dwelling community of organisms. Figure 5.8 shows possible exposure routes of trace metals (including uranium) in an aquatic ecosystem (Jinks and Eisenbud 1972).

Sediments play a significant role in aquatic ecology by serving as a repository for radioactive or chemical substances that pass via bottom-feeding biota to the higher trophic levels. Soluble pollutants introduced into a body of water reach the bottom sediment primarily by adsorption on suspended solids that later deposit on the bottom. The deposited remains of biota that have absorbed pollutants may also be an important source of radioactive pollutants that enter the food chain.

\section{Surveillance Program}

Sediment samples were taken from six locations (see Fig. 5.9) in 1993. At each location, a clean sampling scoop was used to obtain a sample from the bottom of the stream, taking as few rocks as possible. About $2 \mathrm{~kg}$ $(4.5 \mathrm{lb})$ of sediment was placed in a new plastic bag. The samples were then dried and delivered to the analytical laboratory. Table 5.5 lists the collection and analysis frequencies for sediment. 
Table 5.2. Maximum potential external gamma exposure rates at PGDP for 1993

\begin{tabular}{llcc}
\hline \multirow{2}{*}{ Point $^{a}$} & \multicolumn{1}{c}{ Location } & \multicolumn{2}{c}{ Average } \\
\cline { 3 - 4 } & & $(\mu$ R/hour) & (mrem/year) $^{b}$ \\
\hline EG1 & Air sampler perimeter north (PN) & 5.0 & 44 \\
EG2 & Air sampler perimeter east (PE) & 4.8 & 42 \\
EG3 & Air sampler perimeter south (PS) & 48 & $4.2 \times 10^{2}$ \\
EG4 & Air sampler perimeter west (PW) & 14 & $1.2 \times 10^{2}$ \\
EG5 & Air sampler boundary north (BN) & 5.0 & 44 \\
EG6 & Air sampler boundary east (BE) & 4.6 & 40 \\
EG7 & Air sampler 1 mile north (1N) & 3.7 & 33 \\
EG8 & Air sampler 1 mile east (1E) & 5.2 & 45 \\
EG9 & Air sampler 1 mile south (1S) & 4.8 & 42 \\
EG10 & Air sampler 1 mile southeast (1SE) & 5.7 & 50 \\
EG11 & Air sampler 1 mile west (1W) & 5.9 & 52 \\
EG12 & Air sampler in Grahamville & 5.8 & 50 \\
EG13 & House in Magruder Village & 6.4 & 56 \\
EG14 & House in Paducah near Noble Park & 8.3 & 73 \\
EG15 & House south of Paducah on Oaks Road & 6.6 & 58 \\
\hline
\end{tabular}

${ }^{a}$ See Fig. 5.4.

${ }^{\mathrm{b}} 1 \mathrm{mrem} /$ year $=1 \times 10^{-2} \mathrm{mSv} /$ year.

Table 5.3. Quality control data for external gamma exposure at PGDP for 1993

\begin{tabular}{|c|c|c|c|c|c|c|}
\hline \multirow[t]{2}{*}{ Point $^{a}$} & \multirow{2}{*}{ Location and description } & \multicolumn{4}{|c|}{$\begin{array}{l}\text { CY quarter } \\
(\mu \mathrm{R} / \text { hour })\end{array}$} & \multirow[t]{2}{*}{$\begin{array}{l}\text { Average } \\
(\mu \mathrm{R} / \text { hour })\end{array}$} \\
\hline & & 1 & 2 & 3 & 4 & \\
\hline $\mathrm{QC1}$ & Office cycle, C-409 & 1.5 & 1.2 & 1.9 & 2.0 & 1.7 \\
\hline \multirow[t]{2}{*}{ QC2 } & $1 / 2$ office cycle, C-409 & 3.0 & 3.6 & 3.3 & 2.4 & 3.1 \\
\hline & & & & & \multicolumn{2}{|c|}{$55 \%$ agreement } \\
\hline QC3 & Freezer cycle, C-409 & 5.4 & 3.2 & 3.6 & 3.8 & 4.0 \\
\hline \multirow[t]{2}{*}{ QC4 } & $1 / 2$ freezer cycle, C-409 & 3.0 & 3.6 & 1.4 & 4.4 & 3.1 \\
\hline & & & & & \multicolumn{2}{|c|}{$78 \%$ agreement } \\
\hline QC5 & Oven cycle, C-409 & 2.5 & 1.2 & 0.6 & 1.1 & 1.4 \\
\hline \multirow[t]{2}{*}{ QC6 } & $1 / 2$ oven cycle, C-409 & 3.0 & 1.5 & 0.5 & -0.4 & 1.2 \\
\hline & & & & & \multicolumn{2}{|c|}{$86 \%$ agreement } \\
\hline QC7 & Light dependence, unwrapped & 41.2 & 56.6 & 46.5 & 47.3 & 47.9 \\
\hline \multirow[t]{2}{*}{ QC8 } & Light dependence, wrapped & 40.2 & 41.9 & 47.3 & 46.9 & 44.1 \\
\hline & & & & & \multicolumn{2}{|c|}{$92 \%$ agreement } \\
\hline QC9 & $\begin{array}{l}\text { Light dependence, unwrapped } \\
\text { spiked } 100 \text { mrem }\end{array}$ & 89.2 & 75.2 & 84.9 & 78.9 & 82.1 \\
\hline \multirow[t]{2}{*}{ QC10 } & $\begin{array}{l}\text { Light dependence, wrapped } \\
\text { spiked } 100 \mathrm{mrem}\end{array}$ & 87.4 & 79.6 & 82.2 & 77.8 & 81.8 \\
\hline & & & & & \multicolumn{2}{|c|}{$100 \%$ agreement } \\
\hline
\end{tabular}

${ }^{a}$ See Fig. 5.5. 


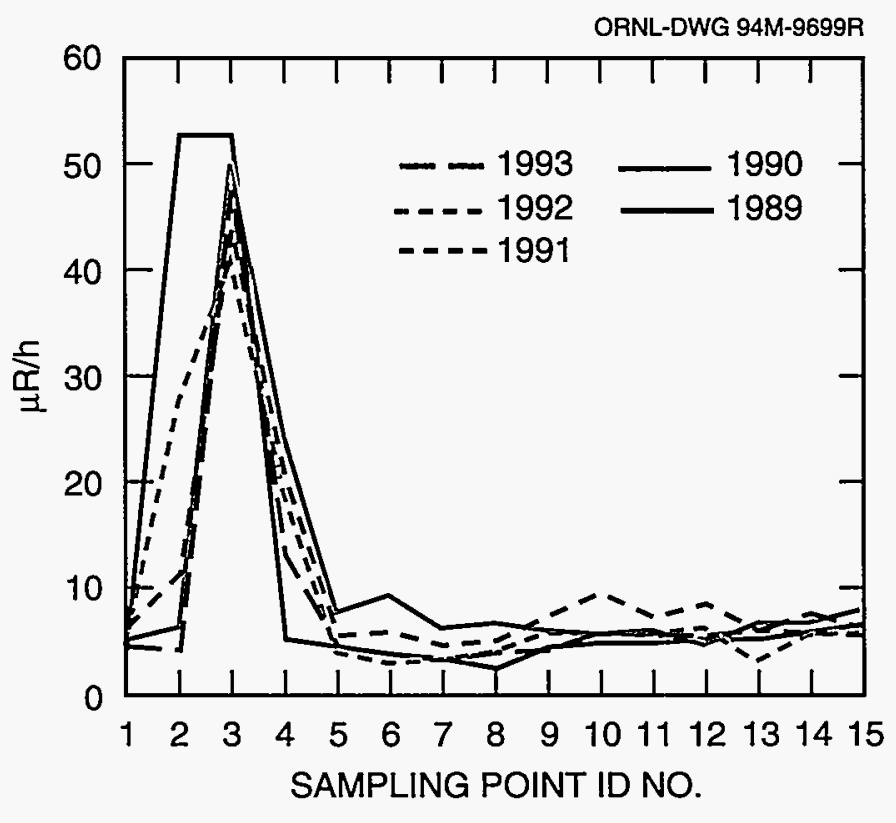

Fig. 5.6. PGDP external gamma radiation, 1989-1993.

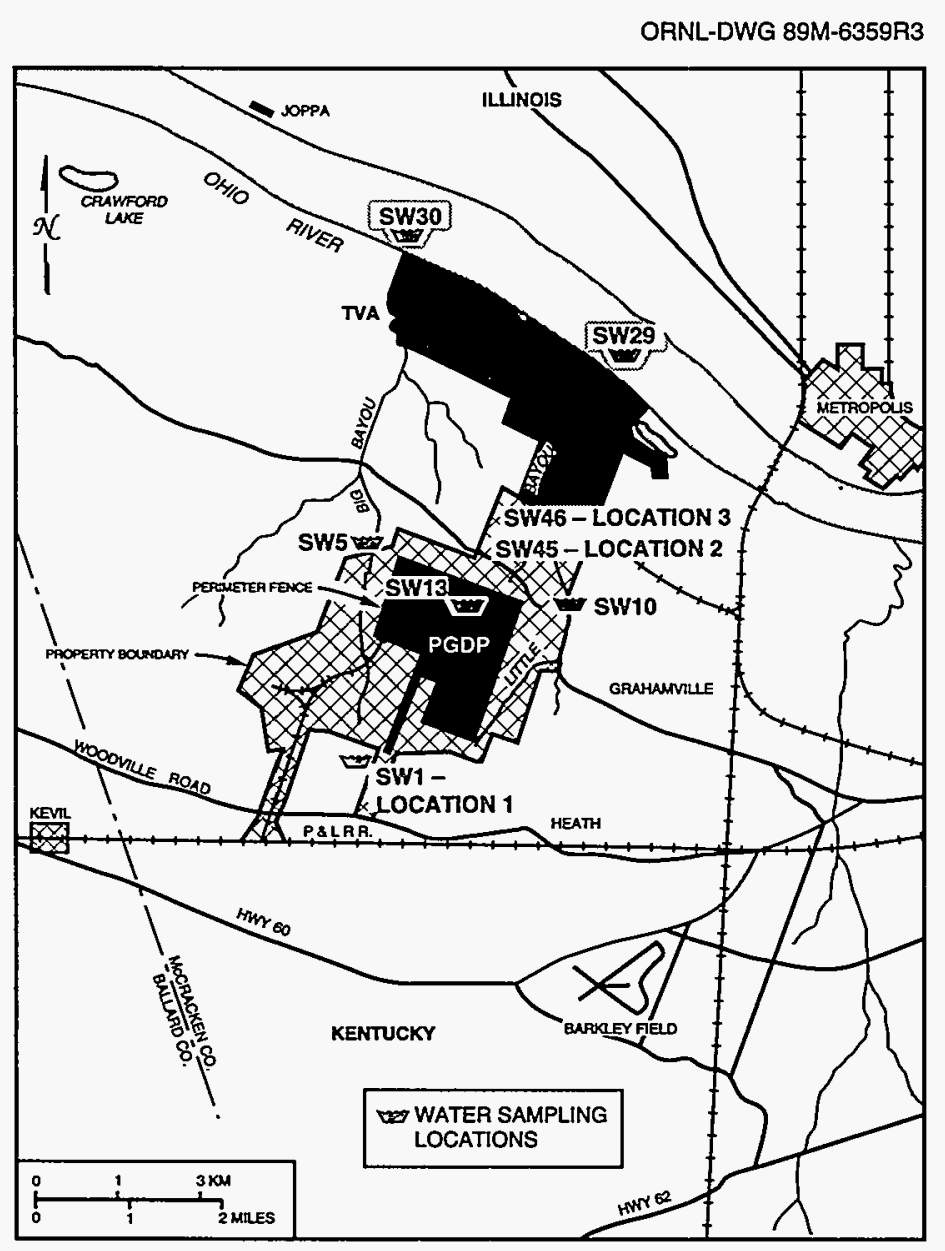

Fig. 5.7. Surface water monitoring locations at PGDP.

\section{Surveillance Results}

Table 5.6 shows the 1993 results for sediment sampling. Locations SS1, SS2, and SS27 are downstream of plant effluents and may be impacted by discharges. Locations SS20, SS21, and SS28 are considered reference, or background, sites to compare with downstream data. SS20 and SS21 are on the same creeks as the impacted areas, whereas SS28 is a similar stream providing a regional reference site. None of the locations contained ${ }^{99} \mathrm{Tc},{ }^{237} \mathrm{~Np},{ }^{239} \mathrm{Pu}$, or ${ }^{230} \mathrm{Th}$ above analytical lower reporting limits. Uranium levels at SS2, downstream Little Bayou Creek, were 69 times higher than at SS21, upstream Little Bayou Creek. Uranium levels at SS2 were two times higher than 1992 levels. Uranium levels at SS1, downstream Big Bayou Creek, were six times higher than at SS20, upstream Big Bayou Creek, and two times higher than 1992 levels. These elevated levels can be attributed to plant operations because the assay is lower than normal uranium. The result confirms past studies in which uranium had been detected and resulted in the posting of Little Bayou Creek to make the public aware that prolonged exposure could result in a dose above background.

\section{SOIL}

Soil is sampled to determine and trend the deposition and accumulation of radionuclides from the atmosphere. Although sampling procedures are designed to minimize the well-known variability found in soils, the significance of individual units of data is small. If trends exist, data collected over a period of years may reveal them.

\section{5-8 Radiological Environmental Surveillance}


Table 5.4. Collection and analysis frequencies of surface water samples at PGDP for 1993

\begin{tabular}{|c|c|c|c|c|}
\hline Station ${ }^{a}$ & Parameter & $\begin{array}{l}\text { Collection } \\
\text { frequency }\end{array}$ & Sample type & $\begin{array}{l}\text { Analysis } \\
\text { frequency }\end{array}$ \\
\hline SW29 & $\begin{array}{l}\text { Dissolved alpha and beta, suspended } \\
\text { alpha and beta, }{ }^{237} \mathrm{~Np},{ }^{239} \mathrm{Pu},{ }^{99} \mathrm{Tc} \text {, } \\
\mathrm{U},{ }^{235} \mathrm{U}\end{array}$ & Monthly & Grab & Monthly \\
\hline SW30 & $\begin{array}{l}\text { Dissolved alpha and beta, suspended } \\
\text { alpha and beta, }{ }^{237} \mathrm{~Np},{ }^{239} \mathrm{Pu},{ }^{99} \mathrm{Tc} \text {, } \\
\mathrm{U},{ }^{235} \mathrm{U}\end{array}$ & Monthly & Grab & Monthly \\
\hline SW13 & $\begin{array}{l}\text { Dissolved alpha and beta, suspended } \\
\text { alpha and beta, }{ }^{99} \mathrm{Tc}, \mathrm{U},{ }^{235} \mathrm{U}\end{array}$ & Weekly & $\begin{array}{l}\text { Grab and 7-day } \\
\text { composite }\end{array}$ & Weekly \\
\hline SW13 & $\begin{array}{l}\text { Dissolved alpha and beta, suspended } \\
\text { alpha and beta, }{ }^{237} \mathrm{~Np},{ }^{239} \mathrm{Pu},{ }^{99} \mathrm{Tc} \text {, } \\
{ }^{230} \mathrm{Th}, \mathrm{U}, \%{ }^{235} \mathrm{U}\end{array}$ & Annually & $\begin{array}{l}\text { Annual } \\
\text { composite }\end{array}$ & Annually \\
\hline SW1 & $\begin{array}{l}\text { Gross alpha and beta, }{ }^{237} \mathrm{~Np},{ }^{239} \mathrm{Pu} \text {, } \\
{ }^{99} \mathrm{Tc}, \mathrm{U}, \%{ }^{235} \mathrm{U}\end{array}$ & Monthly & Grab & Monthly \\
\hline SW5, SW10 & $\begin{array}{l}\text { Gross alpha and beta, }{ }^{237} \mathrm{~Np},{ }^{239} \mathrm{Pu} \text {, } \\
{ }^{99} \mathrm{Tc}, \%{ }^{235} \mathrm{U}\end{array}$ & Monthly & Grab & Monthly \\
\hline
\end{tabular}

${ }^{a}$ See Fig. 5.7.

ORNL-DWG 86M-9977R2

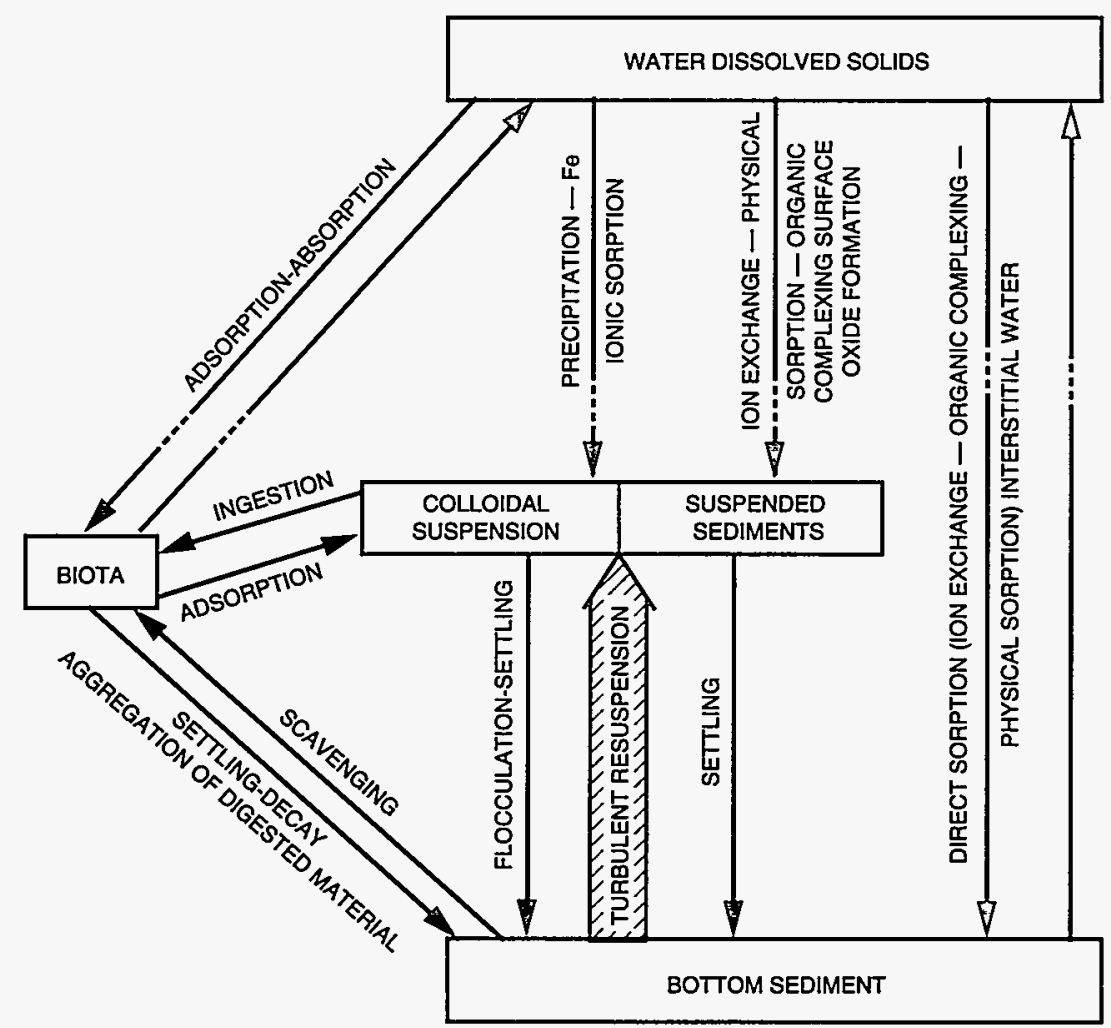

Fig. 5.8. Routes of trace metals in an aquatic ecosystem. Source: S. M. Jinks and M. Eisenbud. 1972. "Concentration Factors in Aquatic Environment," Radia. Data Rep. 13, 243. 


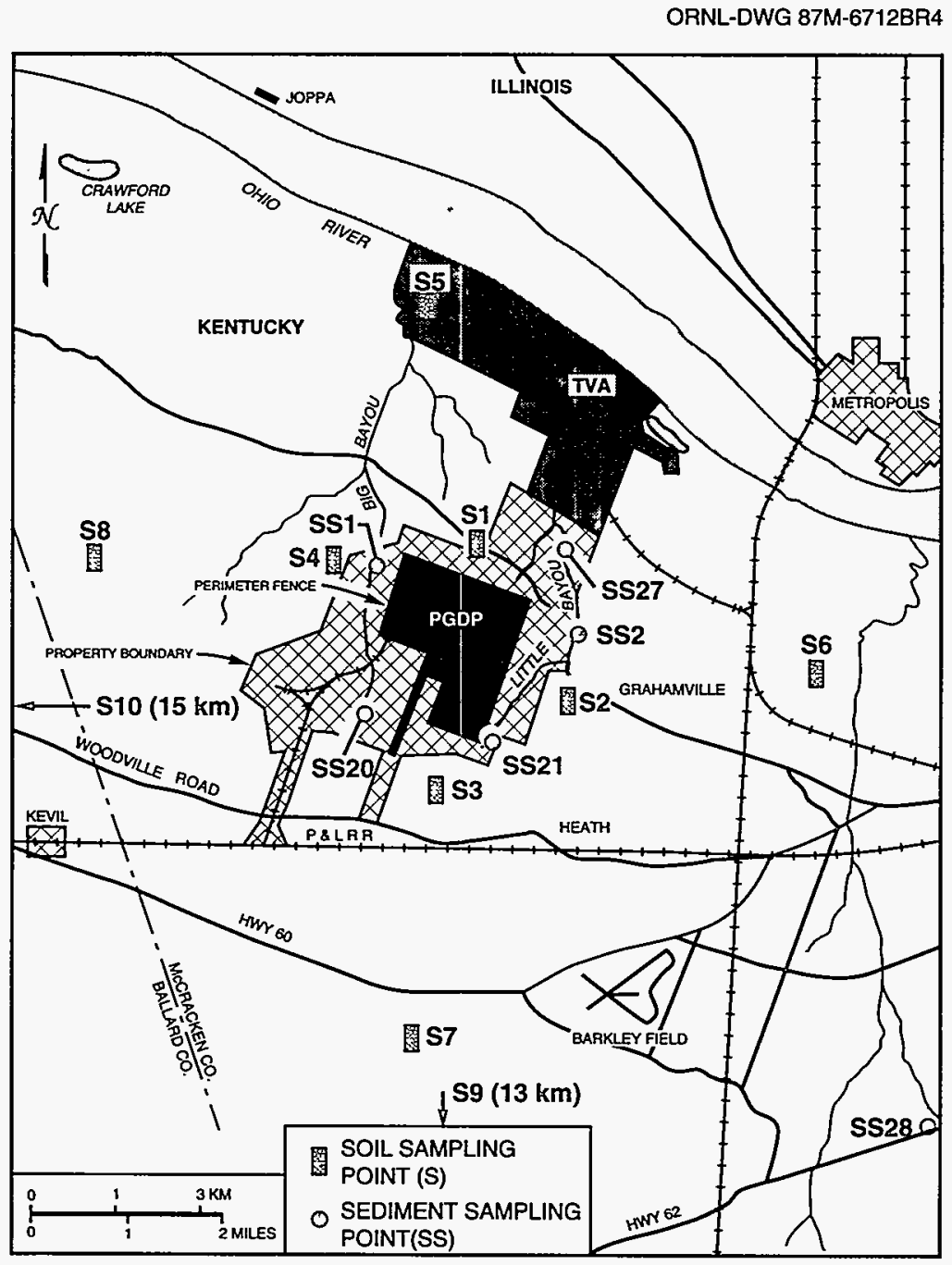

Fig. 5.9. Soil and sediment sampling locations at PGDP.

Table 5.5. Collection and analysis frequencies of soil and sediment samples at PGDP in 1993

\begin{tabular}{ccccc}
\hline Station & Parameter & $\begin{array}{c}\text { Collection } \\
\text { frequency }\end{array}$ & $\begin{array}{c}\text { Sample } \\
\text { type }\end{array}$ & $\begin{array}{c}\text { Analysis } \\
\text { frequency }\end{array}$ \\
\hline \multicolumn{1}{c}{ Soil } \\
S1, S2, S3, S4, S5, S6, & $\mathrm{U}^{2339} \mathrm{Pu},{ }^{237} \mathrm{~Np},{ }^{137} \mathrm{Cs},{ }^{235} \mathrm{U}$, & Annually & Grab & Annually \\
& ${ }^{230} \mathrm{Th},{ }^{99} \mathrm{Tc},{ }^{40} \mathrm{~K}$ & & & \\
$\begin{array}{l}\mathrm{S} \text { S1, SS2, SS20, SS21, } \\
\text { SS27, SS28 }\end{array}$ & ${ }^{137} \mathrm{Cs},{ }^{40} \mathrm{~K},{ }^{237} \mathrm{~Np},{ }^{239} \mathrm{Pu},{ }^{99} \mathrm{Tc}$, & Annually & Grab & Annually \\
\hline
\end{tabular}

${ }^{a}$ See Fig. 5.9. 
Table 5.6. Radionuclide sediment data for PGDP in 1993

\begin{tabular}{lcccccc}
\hline \multicolumn{1}{c}{ Location $^{a}$} & $\begin{array}{c}{ }^{99} \mathrm{Tc} \\
(\mathrm{pCi} / \mathrm{g})^{b}\end{array}$ & $\begin{array}{c}{ }^{237} \mathrm{~Np} \\
(\mathrm{pCi} / \mathrm{g})\end{array}$ & $\begin{array}{c}{ }^{239} \mathrm{Pu} \\
(\mathrm{pCi} / \mathrm{g})\end{array}$ & $\begin{array}{c}{ }^{230} \mathrm{Th} \\
(\mathrm{pCi} / \mathrm{g})\end{array}$ & $\begin{array}{c}{ }^{235} \mathrm{U} \\
(\mathrm{wt} \%)\end{array}$ & $\begin{array}{c}\text { Uranium } \\
(\mu \mathrm{g} / \mathrm{g})\end{array}$ \\
\hline $\begin{array}{l}\text { SS1 downstream Big Bayou } \\
\text { Creek }\end{array}$ & $<17$ & $<0.5$ & $<0.5$ & $<3$ & 0.51 & 10.51 \\
$\begin{array}{l}\text { SS2 downstream Little Bayou } \\
\text { Creek }\end{array}$ & $<17$ & $<0.5$ & $<0.5$ & $<3$ & 0.17 & 200.7 \\
$\begin{array}{l}\text { SS20 upstream Big Bayou (L-1) } \\
\text { Creek }\end{array}$ & $<17$ & $<0.5$ & $<0.5$ & $<3$ & 0.72 & 1.8 \\
$\begin{array}{l}\text { SS21 upstream Little Bayou } \\
\text { Creek }\end{array}$ & $<17$ & $<0.5$ & $<0.5$ & $<3$ & 0.66 & 2.9 \\
$\begin{array}{l}\text { SS27 below north/south } \\
\text { diversion ditch in Little }\end{array}$ & $<17$ & $<0.5$ & $<0.5$ & $<3$ & 0.27 & 9.4 \\
$\quad \begin{array}{l}\text { Bayou Creek } \\
\text { SS28 Massac Creek at Hwy 62 }\end{array}$ & $<17$ & $<0.5$ & $<0.5$ & $<3$ & 0.71 & 0.7 \\
\hline
\end{tabular}

${ }^{a}$ See Fig. 5.9.

${ }^{b} 1 \mathrm{pCi} / \mathrm{g}=3.7 \times 10^{-2} \mathrm{~Bq} / \mathrm{g}$.

\section{Surveillance Program}

Soil samples are taken annually at 10 locations-north, south, east, and west at the property boundary and at distances of $8 \mathrm{~km}$ ( 5 miles) beyond the property boundary (see Fig. 5.9). Remote (background) samples are taken at two locations 13 to $15 \mathrm{~km}$ (8.08 to 9.32 miles) from the plant. Each sampling site was selected because the soil appeared undisturbed or was known to have been undisturbed for a number of years. Two $1-\mathrm{m}^{2}\left(11-\mathrm{ft}^{2}\right)$ areas

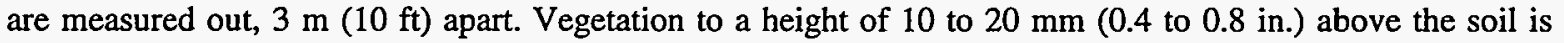
removed. Soil samples to a depth of $5 \mathrm{~cm}\left(2 \mathrm{in}\right.$.) are taken from the center and from each corner of the $1-\mathrm{m}^{2}$ area. The plugs of soil are composited into a labeled plastic bag. Table 5.5 lists sampling parameters and collection and analysis frequencies for soil.

\section{Surveillance Results}

Table 5.7 lists uranium concentrations in soil samples from 1987 through 1993. Although other radiochemical analyses are performed and results summarized, only uranium is presented in a tabular form because it is considered to be the element of concern in PGDP air emissions. The 1993 uranium concentrations show no apparent differences from past data and are within the range for concentrations and assay expected for naturally occurring uranium. The range of soil analyses during 1993 was from a low of $2.1 \mu \mathrm{g} / \mathrm{g}$ at the south background location (S9) to a high of 5.4 at the north plant boundary (S1). However, there was a significant difference, at the 95\% confidence level, between upwind (S3, S4, S7, S8, S9, S10) and downwind (S1, S2, S5, S6) locations. The downwind locations were higher than the upwind locations. Radionuclide analyses were also performed for ${ }^{99} \mathrm{Tc},{ }^{230} \mathrm{Th},{ }^{237} \mathrm{~Np}$, and ${ }^{239} \mathrm{Pu}$, and no detectable concentrations were found at any of the sampling sites.

\section{FOOD CROPS}

Each year, the effects of PGDP operations on local food crops are monitored. Sampling locations are chosen using a land census performed in 1990, along with meteorological data from the plant's tower. These locations may be modified somewhat depending on the availability of targeted vegetables. Corn, tomatoes, and squash are 
Table 5.7. Uranium concentrations (in $\mu \mathrm{g} / \mathrm{g}$ ) in soil at PGDP, 1987-1993

\begin{tabular}{|c|c|c|c|c|c|c|c|}
\hline $\operatorname{Site}^{a}$ & 1987 & 1988 & 1989 & 1990 & 1991 & 1992 & 1993 \\
\hline \multicolumn{8}{|c|}{ Property boundary } \\
\hline S1 north & 4.8 & 4.9 & 2.2 & 5 & 4.3 & 1.5 & 5.4 \\
\hline S2 east & 3.4 & 4.6 & 2.4 & 3.9 & 4.1 & 3.5 & 3.8 \\
\hline S3 south & 5.5 & 4.3 & 5.6 & 7.1 & 4.3 & 3.4 & 2.6 \\
\hline S4 west & 2.5 & 2.2 & 1.4 & 3.3 & 2.9 & 2.6 & 2.8 \\
\hline \multicolumn{8}{|c|}{$8 \mathrm{~km}$ from plant } \\
\hline S5 north & 3.9 & 4.2 & 2.2 & 4.3 & 4.2 & 4 & 3.8 \\
\hline S6 east & 2.6 & 2.3 & 1.1 & 2.5 & 3 & 2.5 & 2.8 \\
\hline S7 south & 2.7 & 2.5 & 1.2 & 2.8 & 2.9 & 2.6 & 2.5 \\
\hline S8 west & 2.8 & 3.4 & 1.2 & 2.9 & 3.3 & 3.1 & 2.8 \\
\hline \multicolumn{8}{|c|}{13 to $15 \mathrm{~km}$ from plant } \\
\hline S9 south & 2.4 & 2.5 & 0.8 & 2.2 & 2.8 & 2 & 2.1 \\
\hline S10 west & 2.9 & 2.1 & 0.7 & 2.7 & 2.9 & 2.4 & 2.6 \\
\hline
\end{tabular}

${ }^{a}$ See Fig. 5.9.

targeted for selection because they are readily available and are eaten in large quantities and because specific uptake information is available for them.

Sample locations are selected using the $60-\mathrm{m}$ wind rose from the previous year. A wind rose is a graph that shows wind direction, intensity, and frequency at a particular location. The previous year's data are used because any airborne emissions from that year are the ones available in the soil for plant uptake. A minimum of five locations (as long as these locations account for $50 \%$ of measured wind directions) are chosen using the data from the wind rose. Additional locations are selected, if needed, until 50\% coverage is reached. If there is no garden in the area or if vegetables are not available, an adjacent sector is selected. If there is no adjacent unselected sector available, this wind direction is eliminated and the next prevalent sector selected.

Food crop monitoring locations for 1993 are shown in Fig. 5.10. Corn, tomatoes, and squash were collected from five locations around the plant and from one reference, or background, area 10 miles southwest of the plant in the least prevalent wind direction. Each sample was analyzed for ${ }^{239} \mathrm{Pu},{ }^{99} \mathrm{Tc},{ }^{230} \mathrm{Th},{ }^{237} \mathrm{~Np},{ }^{235} \mathrm{U}$, ${ }^{234} \mathrm{U}$, and ${ }^{238} \mathrm{U}$. Table 5.8 shows the concentrations of these radionuclides, on a wet-weight basis, in the edible portions of the vegetables. Only radionuclides present above the detection limit at $99 \%$ confidence are shown.

The radionuclides detected, ${ }^{234} \mathrm{U},{ }^{235} \mathrm{U},{ }^{238} \mathrm{U}$, and ${ }^{230} \mathrm{Th}$, are all known to be naturally occurring and also present at the plant. Data from 1992 and 1993 indicate that the levels of these radionuclides in the most prevalent wind directions are detected more often and at levels slightly higher than in the less prevalent directions and the reference area for ${ }^{234} \mathrm{U}$ and ${ }^{235} \mathrm{U}$. Levels for ${ }^{230} \mathrm{Th}$ and ${ }^{238} \mathrm{U}$ were equivalent to the reference location. The effects of these results on off-site dose estimates are discussed in Section 6.

\section{TERRESTRIAL WILDLIFE}

In August 1993 eight deer were harvested in the West Kentucky Wildlife Management Area to monitor the effects of PGDP operations on the ecology of the surrounding area. Two deer obtained as background samples from the Ballard County Wildlife Management Area in 1993 were used for reference. Liver and muscle samples were analyzed for radionuclides. In addition, bone and thyroid samples were analyzed for the radionuclides ${ }^{90} \mathrm{Sr}$ and ${ }^{99} \mathrm{Tc}$, respectively. Because the liver and muscle tissue are considered consumable by hunters, these tissues are evaluated for radiological risks if analyses reveal detectable levels above background, or reference, deer.

\section{5-12 Radiological Environmental Surveillance}




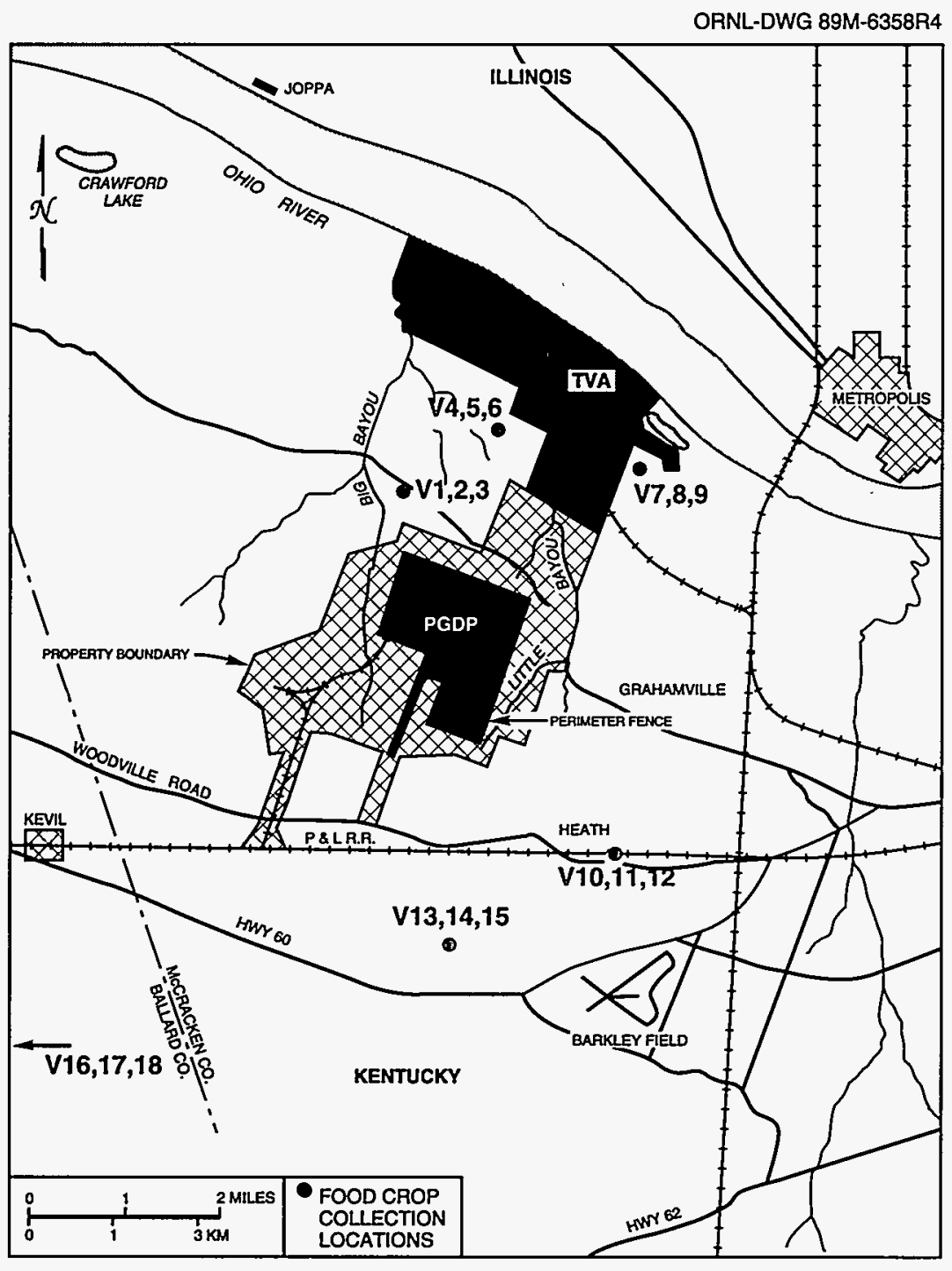

Fig. 5.10. Food crop collection locations near PGDP.
Bone and thyroid samples are used only as indicators of contamination. The results for all detected analytes in liver and muscle samples are summarized in Tables 5.9 and 5.10, respectively.

Most radionuclide results that were statistically different from zero in edible portions of deer tissue were for uranium isotopes. Uranium-234 (a radionuclide seen during all sampling events since 1990) results for both liver and muscle were equivalent compared with background deer. Eight of ten (including two background) liver samples and six of ten (including one background) muscle tissue samples showed detectable ${ }^{234} \mathrm{U}$. Averages were calculated using only positive detectable numbers. The average for liver in reservation deer was $0.009 \mathrm{pCi} / \mathrm{g}\left(3.33 \times 10^{-4}\right.$ $\mathrm{Bq} / \mathrm{g}$ ), and the average for background was $0.012 \mathrm{pCi} / \mathrm{g}$ (4.44 $\left.\times 10^{-4} \mathrm{~Bq} / \mathrm{g}\right)$. The average for muscle in reservation deer was $0.004 \mathrm{pCi} / \mathrm{g}\left(1.48 \times 10^{-4} \mathrm{~Bq} / \mathrm{g}\right)$, and the only positive background was $0.010 \mathrm{pCi} / \mathrm{g}\left(3.70 \times 10^{-4} \mathrm{~Bq} / \mathrm{g}\right)$. The data indicate no significant difference (at $95 \%$ confidence level) between the average concentrations of uranium isotopes in liver for reservation deer and for background deer. All muscle results for ${ }^{234} U$ in reservation deer were less than the

one background result. Detectable results for ${ }^{235} \mathrm{U}$ and ${ }^{238} \mathrm{U}$ were sporadic, three in reservation deer and one in background deer. Detectable results have been seen occasionally in past years for these radionuclides and are thought to be analytical anomalies rather than contamination by the plant. A positive result for ${ }^{239} \mathrm{Pu}$ was also found for reservation deer No. 2; this has never been seen in the past. Future data will be watched for similar results. Detectable concentrations of uranium isotopes and ${ }^{90} \mathrm{Sr}$, a radionuclide present in the atmosphere from worldwide fallout, were found in most bone samples. One detectable result for ${ }^{99} \mathrm{Tc}$ was found in the thyroid of a reservation deer. 
Table 5.8. Analysis results of annual food crop sampling near PGDP for 1993

\begin{tabular}{|c|c|c|c|c|c|c|c|}
\hline \multirow[t]{2}{*}{$\begin{array}{l}\text { Location }^{a} \\
\text { (sample) }\end{array}$} & \multicolumn{7}{|c|}{$\begin{array}{l}\text { Radionuclide } \\
(\mathrm{pCi} / \mathrm{g})^{b}\end{array}$} \\
\hline & ${ }^{237} \mathrm{~Np}$ & ${ }^{239} \mathrm{Pu}$ & ${ }^{99} \mathrm{Tc}$ & ${ }^{230} \mathrm{Th}$ & ${ }^{234} \mathrm{U}$ & ${ }^{235} \mathrm{U}$ & ${ }^{238} U$ \\
\hline \multicolumn{8}{|c|}{ Indicator food crops } \\
\hline 1 (corn) & $c$ & $c$ & $c$ & $c$ & 0.018 & $c$ & $c$ \\
\hline 2 (tomato) & $c$ & $c$ & $c$ & $c$ & 0.018 & 0.006 & 0.008 \\
\hline 3 (squash) & $c$ & $c$ & $c$ & 0.002 & 0.009 & 0.007 & $c$ \\
\hline 4 (corn) & $c$ & $c$ & $c$ & 0.002 & 0.011 & 0.006 & 0.008 \\
\hline 5 (tomato) & $c$ & $c$ & $c$ & $c$ & 0.007 & 0.006 & $c$ \\
\hline 6 (squash) & $c$ & $c$ & $c$ & $c$ & 0.011 & $c$ & 0.010 \\
\hline 7 (corn) & $c$ & $c$ & $c$ & $c$ & 0.013 & $c$ & $c$ \\
\hline 8 (tomato) & $c$ & $c$ & $c$ & $c$ & 0.007 & $c$ & $c$ \\
\hline 9 (squash) & $c$ & $c$ & $c$ & $c$ & 0.009 & $c$ & $c$ \\
\hline 10 (corn) & $c$ & $c$ & $c$ & $c$ & $c$ & $c$ & $c$ \\
\hline 11 (tomato) & $c$ & $c$ & $c$ & $c$ & $c$ & $c$ & $c$ \\
\hline 12 (squash) & $c$ & $c$ & $c$ & $c$ & 0.010 & $c$ & 0.009 \\
\hline 13 (corn) & $c$ & $c$ & $c$ & $c$ & 0.012 & $c$ & $c$ \\
\hline 14 (tomato) & $c$ & $c$ & $c$ & $c$ & 0.013 & $c$ & $c$ \\
\hline 15 (squash) & $c$ & $c$ & $c$ & $c$ & $c$ & $c$ & $c$ \\
\hline \multicolumn{8}{|c|}{ Background food crops } \\
\hline 16 (corn) & $c$ & $c$ & $c$ & $c$ & 0.008 & $c$ & 0.012 \\
\hline 17 (tomato) & $c$ & $c$ & $c$ & 0.002 & $c$ & $c$ & $c$ \\
\hline 18 (squash) & c & $c$ & $c$ & $c$ & 0.008 & $c$ & $c$ \\
\hline
\end{tabular}

${ }^{a}$ See Fig. 5.10.

${ }^{b} 1 \mathrm{pCi} / \mathrm{g}=3.7 \times 10^{-2} \mathrm{~Bq} / \mathrm{g}$.

'Only radionuclides present above detection limits (at $99 \%$ confidence level) are included. 
Table 5.9. PGDP 1993 annual deer harvest-analysis of liver tissue for radionuclides

\begin{tabular}{cccc}
\hline \multirow{4}{*}{ Deer } & \multicolumn{3}{c}{$\begin{array}{c}\text { Radionuclide } \\
(\mathrm{pCi} / \mathrm{g})^{a}\end{array}$} \\
\cline { 2 - 4 } & \multicolumn{4}{c}{${ }^{235} \mathrm{U}$} & ${ }^{238} \mathrm{U}$ \\
\hline 1 & 0.017 & 0.003 & $b$ \\
2 & $b$ & $b$ & 0.003 \\
3 & 0.005 & $b$ & $b$ \\
4 & $b$ & $b$ & $b$ \\
5 & 0.009 & $b$ & $b$ \\
6 & 0.012 & $b$ & $b$ \\
7 & 0.004 & $b$ & $b$ \\
8 & 0.009 & $b$ & $b$ \\
& Background deer & \\
9 & 0.008 & $b$ & $b$ \\
10 & 0.016 & $b$ & $b$ \\
\hline
\end{tabular}

${ }^{a} 1 \mathrm{pCi} / \mathrm{g}=3.7 \times 10^{-2} \mathrm{~Bq} / \mathrm{g}$.

Wot detected.

Table 5.10. PGDP 1993 annual deer harvest-analysis of muscle tissue for radionuclides

\begin{tabular}{ccccc}
\hline \multirow{4}{*}{ Deer } & \multicolumn{4}{c}{$\begin{array}{c}\text { Radionuclide } \\
(\mathrm{pCi} / \mathrm{g})^{a}\end{array}$} \\
\cline { 2 - 5 } & ${ }^{234} \mathrm{U}$ & ${ }^{235} \mathrm{U}$ & ${ }^{238} \mathrm{U}$ & ${ }^{239} \mathrm{Pu}$ \\
\hline & & Indicator deer \\
1 & 0.008 & $b$ & $b$ & $b$ \\
2 & $b$ & $b$ & $b$ & 0.002 \\
3 & 0.005 & $b$ & $b$ & $b$ \\
4 & $b$ & $b$ & $b$ & $b$ \\
5 & 0.005 & $b$ & $b$ & $b$ \\
6 & $b$ & $b$ & $b$ & $b$ \\
7 & 0.001 & $b$ & $b$ & $b$ \\
8 & 0.003 & $b$ & 0.003 & $b$ \\
& & Background deer & \\
9 & 0.010 & 0.005 & $b$ & $b$ \\
10 & $b$ & $b$ & $b$ & $b$ \\
\hline
\end{tabular}

${ }^{a} 1 \mathrm{pCi} / \mathrm{g}=3.7 \times 10^{-2} \mathrm{~Bq} / \mathrm{g}$.

Not detected. 


\begin{abstract}
Most of the radioactive materials released from the Paducah site are present in such low concentrations in the environment that standard monitoring procedures cannot detect them. Therefore, radiation doses to off-site populations are calculated with mathematical models. For 1993, the maximally exposed individual received an estimated dose of 0.0023 mrem from site atmospheric releases and $2.1 \mathrm{mrem}$ from other possible pathways. This dose is a small fraction of the applicable federal dose standard.
\end{abstract}

\title{
INTRODUCTION
}

This section presents the estimated doses to individuals and the surrounding population from Paducah Gaseous Diffusion Plant (PGDP) atmospheric and liquid releases. In addition, potential doses from special case exposure scenarios, such as deer meat consumption and ingestion of locally grown food crops, are estimated.

PGDP discharges effluents, some of which are radioactive and some of which are chemically or biologically reactive. Waste minimization and pollution abatement systems reduce these effluents, and emission and environmental monitoring is used to evaluate these controls, determine compliance with regulations, and allow estimates of the radiation and chemical doses received by members of the public.

U.S. Department of Energy (DOE) Order 5400.5, Radiation Protection of the Public and the Environment, limits the dose to members of the public to less than $100 \mathrm{mrem} / \mathrm{year}$ total effective dose equivalent from all pathways resulting from operation of a DOE facility. Knowledge of the demography and land use of the area surrounding the plant and identification of on-site sources have indicated certain radionuclides and exposure pathways by which people can be exposed to radiation. Figures 6.1 and 6.2 give a comprehensive view of the possible pathways between radioactive materials released to the environment and human beings. In practice, only a few pathways are the major sources of exposure in any given situation.

For the Phase I Remedial Action Site Investigation, CH2M Hill conducted a preliminary assessment of risk from PGDP contaminants to the health of the public (CH2M Hill 1990). This study identified four primary pathways that could potentially contribute greater than $1 \%$ to the total off-site dose: groundwater ingestion, sediment ingestion, ingestion of wildlife and food crops, and exposure to direct radiation. To fully assess the potential dose to the public, a hypothetical group of extreme characteristics is used to postulate an upper limit to the dose of any real group. In addition, the dose from all pathways from atmospheric releases is calculated as required for compliance with the National Emission Standards for Hazardous Air Pollutants Regulations. All dose estimates were rounded to approximate significant figures. For complete descriptions of sampling locations and the data analysis methods and results of the monitoring programs discussed in this section, refer to Section 5 , "Radiological Environmental Surveillance."

\section{TERMINOLOGYINTERNAL DOSE FACTORS}

Most consequences associated with radionuclides released to the environment are caused by interactions between human tissue and various types of radiation emitted by the radionuclides. These interactions involve the transfer of energy from radiation to tissue, possibly resulting in tissue damage. Radiation may come from radionuclides outside the body (in or on environmental media or objects) or from radionuclides deposited inside the body (by inhalation, ingestion, and, in a few cases, absorption through the skin). Exposures to radiation from radionuclides outside the body are called external exposures; exposures to radiation from radionuclides inside the body are called internal exposures. This distinction is important because external exposure occurs only as long as a person is near the external radionuclide; simply leaving the area of the source will stop the exposure. Internal exposure continues as long as the radionuclide remains inside the body.

A number of specialized units have been defined for characterizing exposures to ionizing radiation. Because the damage associated with such exposures results primarily from the deposition of radiant energy in tissue, the 


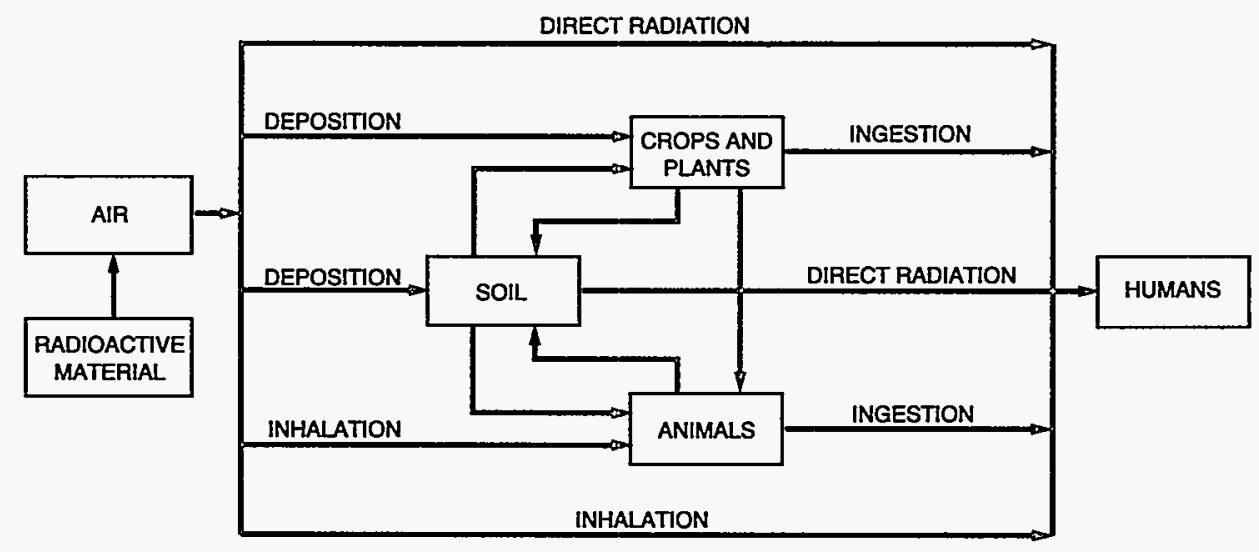

Fig. 6.1. Possible pathways between radioactive material released to the atmosphere and individuals.

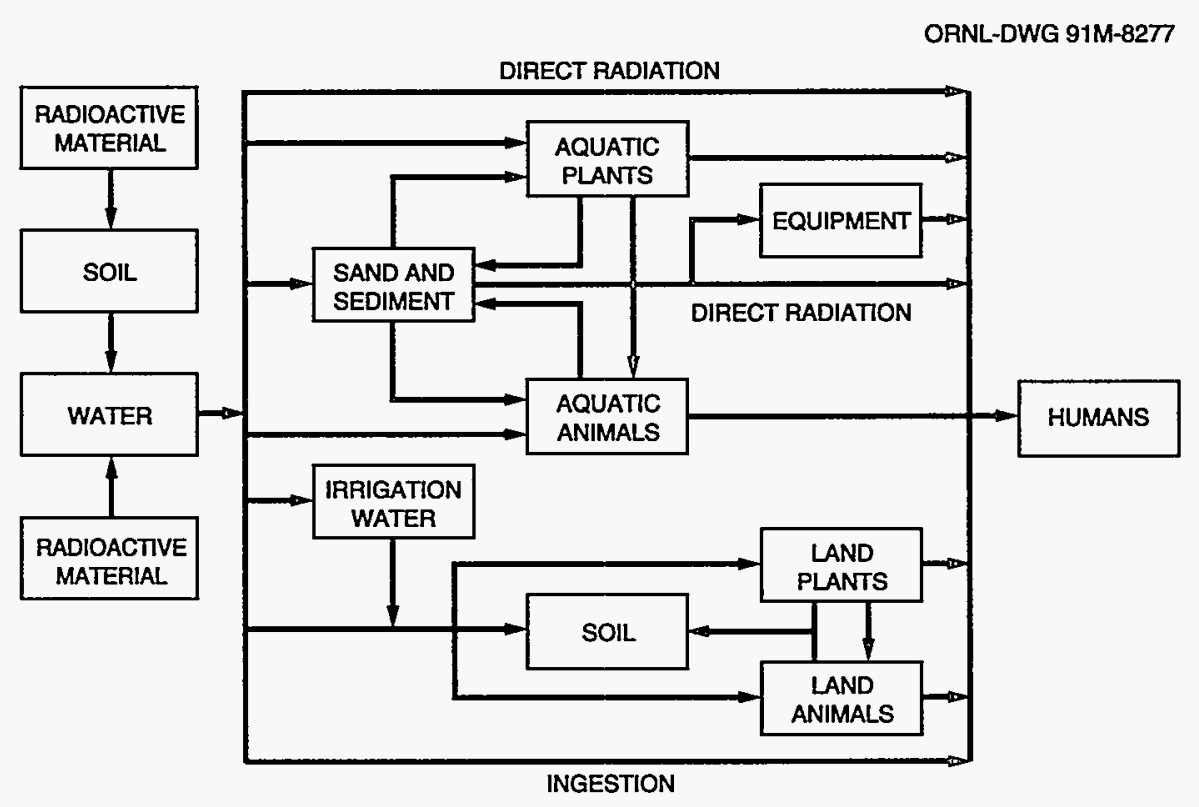

Fig. 6.2. Possible pathways between radioactive material released to groundwater and individuals.

units are defined in terms of the amount of incident radiant energy absorbed by tissue and of the biological consequences of that absorbed energy. These units include the following:

- Committed effective dose equivalent-the total internal dose (measured in millirem) received over a 50-year period resulting from the intake of radionuclides in a 1-year period. The committed effective dose equivalent is the product of the annual intake (picocuries) and the dose conversion factor for each radionuclide (millirems per picocuries).

- Effective dose equivalent-includes the committed effective dose equivalent from internal deposition of radionuclides and the dose from penetrating radiation from sources external to the body. This is a risk-equivalent value and can be used to estimate the health-effects risk to the exposed individual.

- Total effective dose equivalent-the sum of the effective dose equivalent (for external exposures) and the committed effective dose equivalent (for internal exposures). For purposes of compliance with this part, deep dose equivalent to the whole body may be used as the effective dose equivalent for external exposures. 
- Collective effective dose equivalent-a measure in person-rems of long-term radiation effects over a wide area. This measure is calculated by multiplying the average dose within defined areas by the number of persons living in that area.

Table 6.1 shows internal dose factors for several radionuclides of interest at PGDP. These factors are used to determine the committed effective dose equivalent to an adult.

Table 6.1. Internal dose factors for an adult

\begin{tabular}{lccccc}
\hline & & \multicolumn{5}{c}{$\begin{array}{c}\text { Intake }^{a} \\
\text { (mrem/pCi) }\end{array}$} \\
\cline { 3 - 6 } & $\begin{array}{c}\text { Half-life } \\
\text { (years) }\end{array}$ & $\begin{array}{c}\text { Inhalation }^{b} \\
\text { (soluble) }\end{array}$ & $\begin{array}{c}\text { Inhalation }^{b} \\
\text { (slightly } \\
\text { soluble) }\end{array}$ & $\begin{array}{c}\text { Inhalation }^{b} \\
\text { (insoluble) }\end{array}$ & Ingestion \\
\hline${ }^{234} \mathrm{U}$ & $2.4 \mathrm{E}+05$ & $2.7 \mathrm{E}-03$ & $7.1 \mathrm{E}-03$ & $1.3 \mathrm{E}-01$ & $2.6 \mathrm{E}-04$ \\
${ }^{235} \mathrm{U}$ & $7.1 \mathrm{E}+08$ & $2.5 \mathrm{E}-03$ & $6.7 \mathrm{E}-03$ & $1.2 \mathrm{E}-01$ & $2.5 \mathrm{E}-04$ \\
${ }^{238} \mathrm{U}$ & $4.5 \mathrm{E}+09$ & $2.4 \mathrm{E}-03$ & $6.2 \mathrm{E}-03$ & $1.2 \mathrm{E}-01$ & $2.3 \mathrm{E}-04$ \\
${ }^{99} \mathrm{Tc}$ & $2.1 \mathrm{E}+05$ & $8.4 \mathrm{E}-07$ & $7.5 \mathrm{E}-06$ & & $1.3 \mathrm{E}-06$ \\
${ }^{237} \mathrm{~Np}$ & $2.1 \mathrm{E}+06$ & & $4.9 \mathrm{E}-01$ & & $3.9 \mathrm{E}-03$ \\
${ }^{239} \mathrm{Pu}$ & $2.4 \mathrm{E}+04$ & & $5.1 \mathrm{E}-01$ & $3.3 \mathrm{E}-01$ & $4.3 \mathrm{E}-03$ \\
${ }^{230} \mathrm{Th}$ & $7.5 \mathrm{E}+04$ & & $3.2 \mathrm{E}-01$ & $2.6 \mathrm{E}-01$ & $5.3 \mathrm{E}-04$ \\
\hline
\end{tabular}

${ }^{a}$ Source: U.S. DOE. July 1988. Internal Dose Conversion Factors for Calculations of Dose to the Public, DOE/EH-00071, U.S. DOE.

'Includes allowance for skin absorption.

\section{WATERBORNE RADIONUCLIDES}

Liquid effluents are monitored to determine the total quantity of waterborne radionuclides released to the environment. Concentrations of various radionuclides are measured in the creeks and groundwater near the plant. In 1990 a survey of surface water and groundwater users in the vicinity of PGDP was conducted to determine the number of residents using water wells within a 4-mile radius of PGDP and to determine the number of surface water intakes on the Ohio River within 15 miles downstream of the plant. No residents or businesses that responded to the questionnaire reported using a private surface water intake on the Ohio River or on Little or Big Bayou creeks for any part of their water supply. Private groundwater wells are the major water supply for residents surrounding PGDP. Most residents reported using water from their residential wells for drinking, irrigation, and domestic uses.

Under conditions of continuous exposure, members of the public are assumed to ingest $730 \mathrm{~L}$ of drinking water per year. Based on this criterion, the dose to the maximally exposed individual from drinking well water contaminated with ${ }^{99} \mathrm{Tc}$ at the PGDP detection limit $(25 \mathrm{pCi} / \mathrm{L})$ would be $0.024 \mathrm{mrem} / \mathrm{year}$. This dose can be compared with the dose from ingestion of water contaminated with ${ }^{99} \mathrm{Tc}$ at the Safe Drinking Water Act level of $900 \mathrm{pCi} / \mathrm{L}$. This dose would be $0.85 \mathrm{mrem} / \mathrm{year}$. A risk estimation was prepared for the Phase I Site Investigation to assess the potential risk to individuals who might have been previously exposed to contaminated groundwater.

\section{DIRECT RADIATION}

The exposure pathway for external gamma radiation was evaluated using the results of a 1991 thermoluminescent dosimeter survey covering the banks of Little Bayou Creek. The banks were determined to have radioactive contamination above natural background levels. The dose values are the product of the exposure rate (milliroentgens per hour) from the radiological survey and the exposure time at a particular location. 
To determine a realistic exposure time for the Little Bayou Creek area, several assumptions were used. During 1993, the West Kentucky Wildlife Management Area (WKWMA) allowed hunting and dog trials in this area from September 1 to March 30 (213 days). For exposure in the creeks, an individual was assumed to hunt every other day during this period and spend 30 minutes in the Little Bayou Creek bed. This exposure time is probably exaggerated because signs are posted in this area stating that prolonged exposure could result in a dose above background. Also, observations indicate that hunters spend very little time in creeks near PGDP. Using the maximum exposure rate measured in the Kentucky Pollutant Discharge Elimination System 011 ditch (which discharges into Little Bayou Creek) as the worst-case estimate for Little Bayou Creek, the dose above background to this maximally exposed individual would be $1 \mathrm{mrem} / \mathrm{year}$. Even using these extreme assumptions, the potential dose is within the guideline value of less than $10 \mathrm{mrem} / \mathrm{year}$ from any one pathway.

\section{CONTAMINATED SEDINENT IN LITTLE BAYOU CREEK}

Exposure to contaminated sediment in Little Bayou Creek could occur during fishing, hunting, or other recreational activities. Contact and exposure could occur primarily through incidental ingestion of contaminated sediment or inhalation of contaminated particles. The estimated worst-case dose above background that would be received by an individual who was assumed to spend time in the WKWMA every other day during the season would be $1 \mathrm{mrem} /$ year.

\section{INGESTION OF TERRESTRIAL FOODSTUFFS}

The effect of intake of a radionuclide by ingestion depends on the concentration of the radionuclide in food and drinking water and on the individual's consumption patterns. The estimated intake of a radionuclide is multiplied by the appropriate ingestion dose factor to provide the estimate of committed effective dose equivalent resulting from the intake.

Terrestrial wildlife, such as deer, can come into contact with contaminated soil, ingest plants that have taken up contaminants or become coated with contaminated dust, or ingest contaminated water. Hunting is permitted in the WKWMA surrounding PGDP, and the limit for deer harvest is two deer per person per season. Assuming that an individual kills two average-weight deer and consumes the edible portions of those deer during the year, the dose to this individual based on the maximum detected concentrations of any radionuclide in the deer muscle would be $0.08 \mathrm{mrem} / \mathrm{year}$. The only radionuclide present above the detection limit was ${ }^{234} \mathrm{U}$. This ingestion dose can be compared with the calculated dose from the background deer of $0.10 \mathrm{mrem} / \mathrm{year}$, which includes naturally occurring radionuclides. The deer used to calculate the background dose were taken from the Ballard County Wildlife Management Area, an area unaffected by PGDP operations. Therefore, when the analyzed dose occurring naturally is subtracted from the WKWMA dose, the contribution to dose from PGDP operations is negligible: in this case, zero.

Ingestion doses from homegrown fruits and vegetables were also calculated. The only radioactive material with uptake sufficient to be measured was ${ }^{234} U$. This uranium isotope was found in measurable concentrations only in corn and squash. Using the maximum detected concentrations for the two vegetables, the worst-case individual dose above background was calculated to be $0.12 \mathrm{mrem} / \mathrm{year}$. This calculation assumed that an individual ate a portion of each food crop every day of the year.

\section{AIRBORNE RADIONUCLIDES}

At PGDP, radioactive emissions to air are monitored to determine the extent to which the general public could be exposed and to demonstrate compliance with U.S. Environmental Protection Agency (EPA) regulations and DOE directives on radiation exposure to the public. Airborne radioactivity from PGDP operations is normally too low to be detected in the presence of natural background radiation in the environment. Therefore, potential doses to the public are calculated with a dispersion model. This model calculates how measured quantities of released radionuclides mix with the atmosphere, where they travel, how they are diluted, and where they could deposit. Once the dispersion is calculated, population data and concentration/dose conversion factors are used to calculate individual and population doses. These doses include exposure from all the pathways represented in Fig. 6.1, although the primary pathway of exposure is inhalation. The primary contributors to the inhalation dose are ${ }^{234} \mathrm{U}$ and ${ }^{238} \mathrm{U}$. 
The radiation dose calculations were performed using the Clean Air Act Assessment Package-88 (CAP-88) of computer codes. This package contains the EPA's most recent version of the AIRDOS-EPA computer code, which implements a steady-state, Gaussian plume, atmospheric dispersion model to calculate environmental concentrations of released radionuclides and Regulatory Guide 1.109 food-chain models to calculate human exposures, both internal and external, to radionuclides deposited in the environment. The EPA's latest version of the DARTAB computer code then uses the human exposure values to calculate radiation doses to the public from radionuclides released during the year. The dose calculations use dose conversion factors from the latest version of the RADRISK data file, which the EPA provides with CAP-88.

The computer codes used plant-specific radionuclide emission data for 1992 (no 1993 data were available), meteorological data collected during 1992 (no 1993 data) at the 60-m station at the Paducah site, and dose conversion factors specified in the CAP-88 codes. Organ weighing factors used in estimating effective dose equivalents are also based on International Commission on Radiological Protection (ICRP) recommendations (ICRP 1977).

The calculated 50-year committed effective dose equivalent (internal) to the maximally exposed individual was estimated to be $0.0023 \mathrm{mrem}(0.000023 \mathrm{mSv})$, which is well below the 10 -mrem limit. The dose to the maximally exposed individual, who under most circumstances is the person living closest to the plant in the predominant wind direction, is calculated each year. The maximally exposed individual for 1993 is located $2097 \mathrm{~m}(6700 \mathrm{ft})$ north of the plant site.

The collective effective dose equivalent is a good measure of long-term radiation effects over a wide area. The 1993 collective effective dose equivalent for the 500,500 residents within $80 \mathrm{~km}$ (50 miles) of the plant site was estimated to be 0.011 person-rem from PGDP emissions. This dose can be compared with a collective dose for the same population of $2 \times 10^{5}$ person-rem/year from natural background radiation.

\section{CONCLUSIONS}

Table 6.2 contains a summary of the annual dose from radiological contaminants that could potentially be received by a member of the public living near PGDP, assuming worst-case exposure from all major pathways. The calculated maximum combined (internal and external) dose to an individual is $2.1 \mathrm{mrem} / \mathrm{year}$. This level is well below the DOE annual dose limit of $100 \mathrm{mrem} / \mathrm{year}$ to members of the public. The major contributors to the dose are direct external radiation from and ingestion of sediment in or near the Little Bayou Creek bed. Signs have been posted in this area to notify the public of the elevated radiation levels.

Estimates of radiation doses presented in this report were calculated using the dose factors provided by DOE (DOE 1988). These dose factors are based on ICRP Publication 30, Limits of Intakes of Radionuclides by Workers (ICRP 1979), with modifications from ICRP. 
Table 6.2. Summary of potential radiological dose for 1993 from PGDP Worst-case combined exposure pathways

\begin{tabular}{lccc}
\hline \multicolumn{1}{c}{ Pathway } & $\begin{array}{c}\text { Dose } \\
(\mathrm{mrem} / \mathrm{year})^{a, b}\end{array}$ & Portion of total & $\begin{array}{c}\text { Standard } \\
\text { (mrem/year) }\end{array}$ \\
\hline Ingestion of well water & 0.024 & $<0.01$ & $4^{c}$ \\
Ingestion of sediments & 1 & 0.64 & $10^{d}$ \\
Ingestion of food crops & 0.1 & 0.03 & $10^{d}$ \\
Ingestion of deer meat & $0^{e}$ & 0 & $10^{d}$ \\
$\begin{array}{l}\text { Direct radiation-Little } \\
\text { Bayou Creek }\end{array}$ & 1 & 0.32 & $10^{d}$ \\
$\begin{array}{l}\text { Atmospheric releases } \\
\text { Total annual dose above } \\
\text { background-all pathways }\end{array}$ & $0.0023^{f}$ & $<0.01$ & $10^{d, g}$ \\
\hline
\end{tabular}

${ }^{a}$ Dose values were rounded to yield the correct number of significant digits based on all the 1993 data used to estimate the worst-case dose from all exposure pathways and from estimated significant figures in atmospheric releases per DOE/EH-0173T, Environmental Regulatory Guide for Radiological Effluent Monitoring and Environmental Surveillance.

${ }^{b} 1 \mathrm{mrem}=1 \times 10^{2} \mathrm{mSv}$.

'Title 40, Code of Federal Regulations, Part 141 (40 CFR 141), "National Interim Primary Drinking Water Regulations." Under these regulations, persons consuming drinking water shall not receive an annual whole body dose of more than 4 mrem (0.04 mSv). DOE Order 5400.5, Radiation Protection of the Public and the Environment, interprets this dose as effective dose equivalent of no more than $4 \mathrm{mrem}(0.04 \mathrm{mSv})$.

DOE standard in DOE Order 5400.5.

${ }^{e}$ Calculated dose for reservation deer was less than the background, or reference, deer; therefore, the dose was assumed to be zero.

Aost all of the 50-year committed effective dose was received during 1993.

${ }^{8}$ U.S. Environmental Protection Agency standard in 40 CFR 61, Subpart H (National Emission Standards for Hazardous Air Pollutants), December 1989. 


\section{Nonradiological Effluent Monitoring}

D. W. Jones,

W. D. Malis, and C. C. Travis

\section{Abstract}

Nonradioactive airborne emissions at the Paducah site are regulated by the Kentucky Division for Air Quality and are measured by continuous sampling and process knowledge. Results for 1993 indicate that all Paducah airborne emissions are within permit limits and regulatory standards. Monitoring of liquid effluents is conducted according to the Kentucky Pollutant Discharge Elimination System. No exceedences of permits limits occurred in 1993.

\section{INTRODUCTHON}

Nonradioactive airborne emissions from Paducah Gaseous Diffusion Plant (PGDP) are measured by continuous sampling and process knowledge. The results of the measurements indicate that PGDP nonradiological emissions are within permit limits and regulatory standards.

Monitoring of nonradiological species in liquid effluents is documented in the PGDP Environmental Monitoring Plan (MMES 1992a) and is further defined in the Kentucky Pollutant Discharge Elimination System (KPDES) permit, KY-0004049, and the landfill permit, 073.14. Sampling and analytical activities are the responsibility of Martin Marietta Utility Services, Inc. The Environmental Monitoring Department, part of the Environmental and Waste Management Division, provides sampling support. The Analytical Laboratory, part of the Technical Services Division, provides analytical measurements. Effluents are monitored for nonradiological species as listed on the permit governing the discharge.

\section{ARBORNE EFFLUENTS}

\section{Applicable Regulations}

Nonradiological airborne emissions from PGDP are regulated by the Kentucky Division for Air Quality (KDAQ) and the U.S. Environmental Protection Agency (EPA). PGDP operates under one operating permit (No. 0-85-110), which was issued by the KDAQ in September 1985. The permit lists 27 emission points. (Five emission points, the chemical unloading facilities, are grouped under one emission point on the permit.) The permit has no expiration date. However, when the KDAQ establishes its new permit program under Title V of the Clean Air Act Amendments of 1990, permits issued under that program will expire after a maximum of five years from the date of issuance.

PGDP is also subject to KDAQ Kentucky Administrative Regulations, which establish requirements and standards for new and existing specific sources such as indirect heat exchangers (fossil fuel-fired boilers), surface coating operations (paint shops), open burning, fugitive emissions, and general process operations. The KDAQ regulatory and permit standards for the two coal- or oil-fired boilers and the one gas- or oil-fired boiler at PGDP are:

\begin{tabular}{llrlrl}
\hline & \multicolumn{2}{c}{ Boiler 1 (gas or oil) } & \multicolumn{2}{c}{ Boilers 2 and 3 (coal or oil) } \\
Sulfur dioxide & $0.8 \mathrm{lb} / 10^{6} \mathrm{Btu}$ & 99.9 tons/year & $3.1 \mathrm{lb} / 10^{6} \mathrm{Btu}$ & 1604 tons/year \\
Particulates & $0.1 \mathrm{lb} / 10^{6} \mathrm{Btu}$ & 18.9 tons/year & $0.242 \mathrm{lb} / 10^{6} \mathrm{Btu}$ & 125 tons/year \\
\hline
\end{tabular}

In 1986 the KDAQ promulgated regulations to control air toxic emissions. The air toxic regulations established emission standards for sources that emit toxic compounds. To comply with these regulations, PGDP hired an environmental subcontractor to locate and determine the emissions of all airborne toxic compounds from the plant. The emissions were submitted to the KDAQ on an updated permit application in 1988. In addition to 
this application, PGDP completed a stack/vent survey in 1992, which identified all airborne emission points. These emission points were also submitted to the KDAQ on updated permit applications. To date, KDAQ has not issued an updated operating permit based on applications submitted subsequent to the 1985 operating permit.

The EPA promulgates regulations to control airborne radionuclide emissions and emissions that deplete stratospheric ozone. Airborne radionuclide emissions are discussed in Section 4, "Radiological Effluent Monitoring." As a result of the Clean Air Act Amendments of 1990, the EPA has promulgated regulations, under Title VI of the act, to control the emission of compounds that deplete stratospheric ozone. The regulations applicable to PGDP deal primarily with prohibition of intentional releases, required training for technicians, and requirements to repair excessive leakage of compounds that deplete stratospheric ozone. The major impact of Title VI is the phaseout of production of chlorofluorocarbon (CFC)-114 by 1995. PGDP uses CFC-114 as a coolant for the gaseous diffusion cascade. PGDP has identified at least two substitute candidates for CFC-114 and is continuing to evaluate these candidates.

\section{Monisoring Program}

Nonradiological emissions of concern at PGDP include sulfur dioxide $\left(\mathrm{SO}_{2}\right)$, carbon monoxide, oxides of nitrogen $\left(\mathrm{NO}_{\mathrm{x}}\right)$, particulate matter less than 10 microns in diameter $\left(\mathrm{PM}_{10}\right)$, volatile organic compounds, gaseous fluorides, and toxic air pollutants. Facilities and operations that release such emissions include the three fossil fuel-fired boilers, the paint shop fuel dispensing, and the gaseous diffusion cascade.

The C-310 stack is sampled continuously for gaseous fluoride emissions (as well as radiological constituents). KDAQ regulation 401 KAR 53:010 establishes an ambient air quality standard for gaseous fluorides. Air dispersion modeling has indicated that gaseous fluoride emissions of $50 \mathrm{lb} / 12$ hours will not result in an exceedence of the KDAQ ambient air quality standard. There were no gaseous fluoride emissions in 1993 that exceeded $50 \mathrm{lb}$ in a 12-hour period.

Sulfur dioxide emissions from coal- and oil-fired boilers 2 and 3 are measured continuously by an in-stack electronic monitor. Although this monitor provides a real-time indication of $\mathrm{SO}_{2}$ emissions, PGDP uses EPA Guidance Document AP-42, Compilation of Air Pollution Emission Factors, to report all steam plant emissions to the KDAQ. The continuous $\mathrm{SO}_{2}$ monitor serves as a backup and a real-time indicator of potential emission problems.

\section{LIQUID EFFLUENTS}

In addition to radiological parameters on the Kentucky Pollutant Discharge Elimination System (KPDES) permit, specific radionuclide analysis and indicator gross activity analyses are conducted on liquid effluent samples. Four locations have continuous, flow-proportional samplers to measure continuously flowing effluents. At eight other locations with intermittent flows, grab samples at various frequencies are used to measure discharges (MMES 1992a). These locations are shown in Fig. 7.1. Locations 004, 006, and 014 are not included in this program because there is little potential for radiological discharges at those points or because discharges at those locations flow through a monitored outfall. As shown in Table 7.1, outfalls 006 and 014 receive or discharge Ohio River water, which does not enter a facility with radiological materials. Location 004 discharges through outfall 008 , which is monitored. Locations 003 and 005 do not discharge.

\section{Applicable Regulations}

The Clean Water Act is administered for PGDP by the Kentucky Division of Water (KDOW) through the KPDES Wastewater Discharge Permitting Program. The current KPDES permit became effective on November 1, 1992. This permit contained limits based on water quality criteria with a zero flow stream. PGDP adjudicated the portions of the permit that contained unattainable effluent limits and implemented the portions of the permit not under adjudication. The KDOW granted a stay from the adjudicated limits while an agreed order is being negotiated. The stay applies to the limits for temperature, phosphorus, $\mathrm{pH}$, cadmium, chromium, copper, lead, nickel, and zinc. 
ORNL-DWG 87M-6710R3

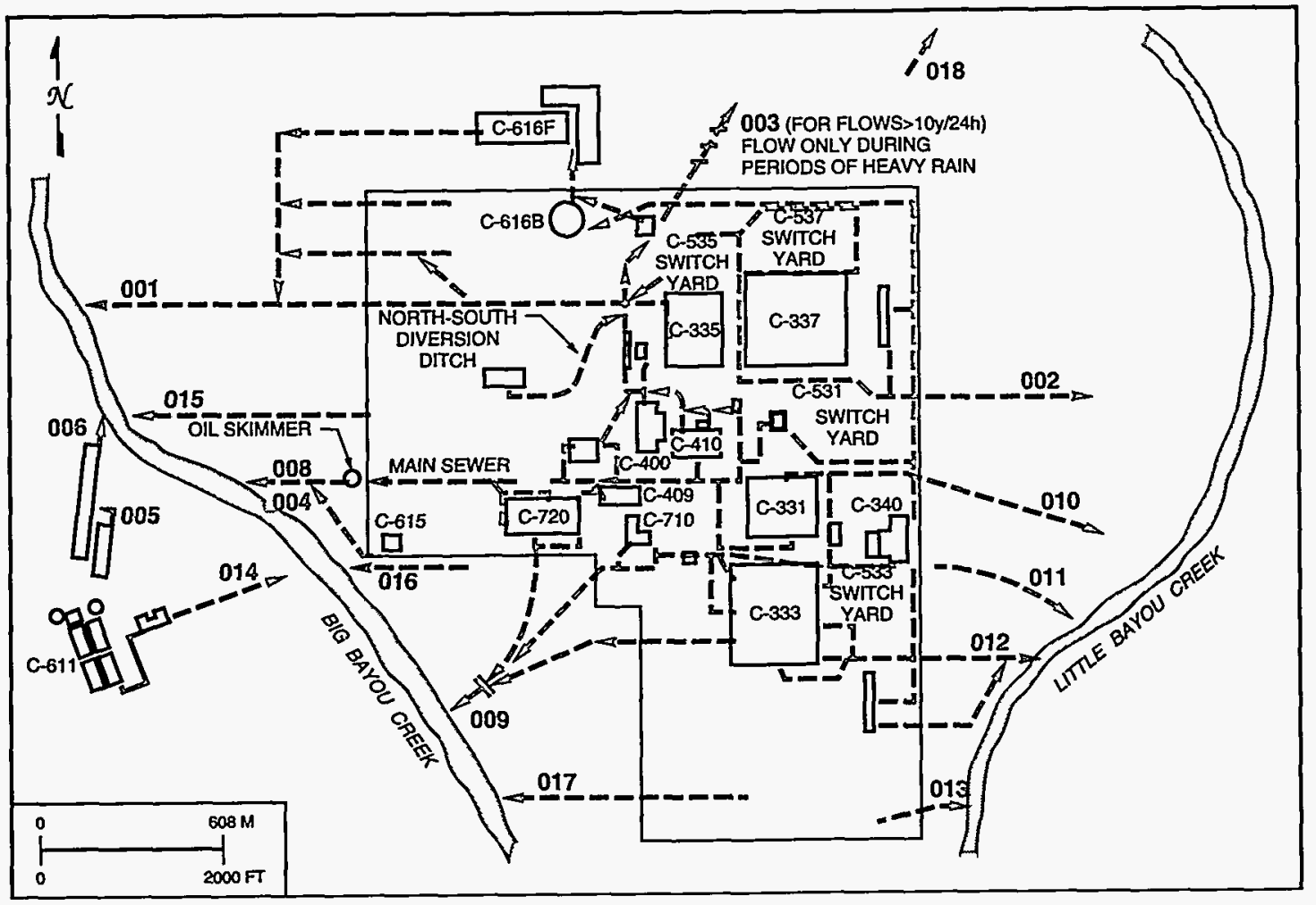

Fig. 7.1. KPDES outfall locations at PGDP.

\section{Monitoring Program}

Monitoring of the individual outfalls was conducted in accordance with the KPDES permit. Table 7.1 lists all outfalls and their contributing processes, and Fig. 7.1 shows the locations of the outfalls. Title 40, Code of Federal Regulations, Part 136, lists the specific sample collection, preservation, and analytical methods acceptable for the types of pollutants to be analyzed. Preservation in the field is conducted per $40 \mathrm{CFR} 136$, and chain-of-custody procedures are followed after collection and during transport to the analytical laboratory. The samples then are accepted by the laboratory and analyzed per accepted procedures listed in 40 CFR 136 for the parameters called for by the KPDES permit.

Surface runoff from the C-746-S residential landfill and the C-746-T inert landfill is monitored quarterly. Monitoring locations are shown in Fig. 7.2. Collection and analysis frequencies are shown in Table 7.2. These locations are directly on the landfills and flow into KPDES outfall 018. Sampling is performed to comply with Kentucky Division of Waste Management permit 073.14 requirements for landfill operations. The residential landfill permit had expired but has been extended. Data were reviewed against environmental performance standards and KPDES 018 limits. Sampling and analysis are performed to monitor for the presence of any leachate leaving the landfill. Background water quality is sampled at Big Bayou Creek location SW1.

\section{Monitoring Results}

Analytical results are reported to the KDOW each month in a discharge monitoring report, which includes the status of intermittent flowing outfalls, a detection limit discussion, and toxicity data collected during the month (if applicable).

No exceedences of the permit limits in effect occurred during the year (see Fig. 7.3). In January, a slight oil sheen was observed leaving the facility at outfall 008.

Data comparisons were made using a one-tailed t-test at $95 \%$ confidence level for nonradiological results comparing each landfill location (SW45 and SW46) with reference, or background, data taken at upstream Big 
Table 7.1. KPDES outfalls at PGDP

\begin{tabular}{|c|c|c|}
\hline Location $^{a}$ & Drainage source & Contributing process \\
\hline 001 & $\begin{array}{l}\text { C-616, C-600, C-400, C-410, } \\
\text { C-635, C-335 C-337, C-535, } \\
\text { C-537, C-746-A, C-747-A, } \\
\text { C-635-6 }\end{array}$ & $\begin{array}{l}\text { Recirculating cooling water blowdown treatment } \\
\text { effluent, coal-pile runoff, once-through cooling } \\
\text { water, surface runoff, roof and floor drains, treated } \\
\text { uranium solutions, sink drains }\end{array}$ \\
\hline 002 & C-360, C-637, C-337-A & $\begin{array}{l}\text { Once-through cooling water, roof and floor drains, sink } \\
\text { drains, extended aeration sewage treatment system }\end{array}$ \\
\hline 003 & North edge of plant & Storm overflow of north/south diversion ditch discharges \\
\hline 004 & $\begin{array}{l}\text { C-615 sewage treatment plant, } \\
\text { C-710, C-728, C-750, C-100, } \\
\text { C-620, C-400 }\end{array}$ & $\begin{array}{l}\text { Domestic sewage, laboratory sink drains, motor } \\
\text { cleaning, garage drains, laundry, machine coolant } \\
\text { treatment filtrate, condensate blowdown, once- } \\
\text { through cooling water }\end{array}$ \\
\hline 005 & C-611 primary sludge lagoon & $\begin{array}{l}\text { Water treatment plant sludge, sand filter backwash, } \\
\text { laboratory sink drains }\end{array}$ \\
\hline 006 & C-611 secondary lagoon & $\begin{array}{l}\text { Water treatment plant sludge, sand filter backwash, } \\
\text { laboratory sink drains from outfall } 005\end{array}$ \\
\hline 007 & $\begin{array}{l}\text { Although outfall is still listed } \\
\text { on the permit, the only } \\
\text { discharge is storm water } \\
\text { runoff, which has no } \\
\text { monitoring requirements or } \\
\text { limitations }\end{array}$ & \\
\hline 008 & $\begin{array}{l}\text { C-743, C-742, C-741, C-723, } \\
\text { C-721, C-728, C-729, C-400, } \\
\text { C-420, C-410, C-727, C-411, } \\
\text { C-331, C-310, C-724, C-744, } \\
\text { C-600, C- } 405, \text { C-409, C-631, } \\
\text { C-720 }\end{array}$ & $\begin{array}{l}\text { Surface drainage, roof and floor drains, once-through } \\
\text { cooling water, paint shop discharge, condensate, } \\
\text { instrument shop cleaning area, metal-cleaning rinse } \\
\text { water, sink drains }\end{array}$ \\
\hline 009 & $\begin{array}{l}\text { C-810, C-811, C-331, C-333, } \\
\text { C-310, C-100, C-102, C-101, } \\
\text { C-212, C-200, C-300, C-320, } \\
\text { C-302, C-750, C-710, C-720 }\end{array}$ & $\begin{array}{l}\text { Surface drainage, roof and floor drains, condensate, } \\
\text { once-through cooling water, sink drains }\end{array}$ \\
\hline 010 & $C-531, C-331$ & $\begin{array}{l}\text { Switchyard runoff, roof and floor drains, condensate, } \\
\text { sink drains }\end{array}$ \\
\hline 011 & $\begin{array}{l}\text { C-340, C- } 533, \mathrm{C}-532, \mathrm{C}-315 \\
\text { C- } 333, \mathrm{C}-331\end{array}$ & $\begin{array}{l}\text { Once-through cooling water, roof and floor drains, } \\
\text { switchyard runoff, condensate, sink drains }\end{array}$ \\
\hline 012 & C-633, C-533, C-333-A & $\begin{array}{l}\text { Roof, floor, and sink drains runoff; condensate; surface } \\
\text { runoff; extended aeration sewage treatment system }\end{array}$ \\
\hline 013 & Southeast corner of plant & Surface runoff \\
\hline 014 & C-611 U-shaped sludge lagoon & Sand filter backwash, sanitary water \\
\hline 015 & West-central plant areas & Surface runoff \\
\hline 016 & Southwest corner of plant & Surface runoff \\
\hline 017 & Extreme south area of plant & Surface runoff \\
\hline 018 & Landfill at north of plant & Surface runoff \\
\hline
\end{tabular}

${ }^{a}$ See Fig. 7.1. 
ORNL-DWG 89M-6359R3

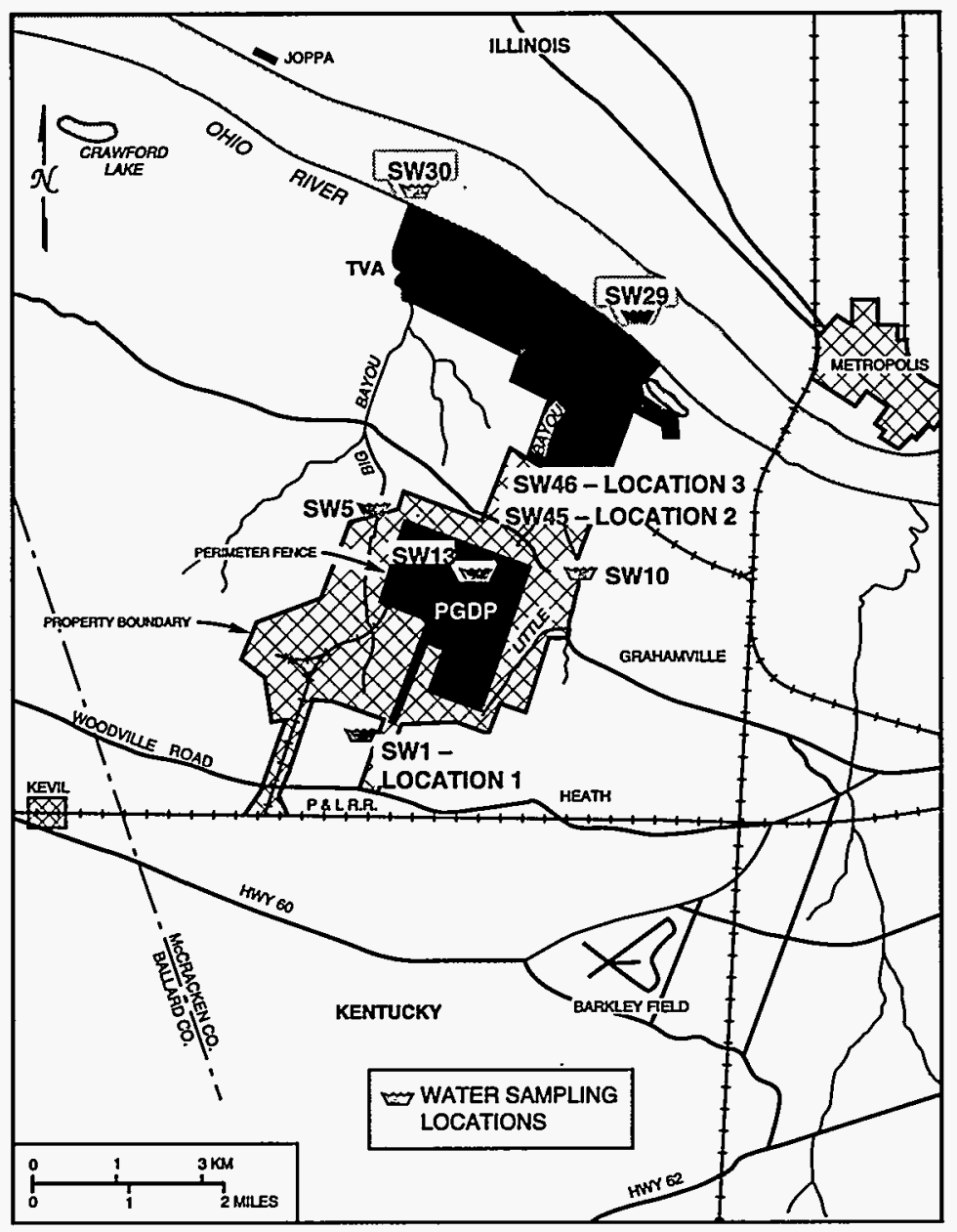

Bayou Creek (SW1). In all instances, a problem is indicated if there is an increase over natural background. Sulfate was significantly elevated at both SW45 and SW46. Statistical analyses were not possible for sulfate, iron, sodium, dissolved solids, total solids, and total suspended solids because of insufficient data. However, these parameters were elevated at SW45 and SW46 when compared with data from SW1. Erosion control measures are taken at the landfills to minimize effects to the environment from raw dirt washing into KPDES outfall 018.

Fig. 7.2. Surface water monitoring locations at PGDP.

Table 7.2. Collection and analysis frequencies of surface water samples at PGDP in 1993

\begin{tabular}{|c|c|c|c|c|}
\hline Station $^{a}$ & Parameter & $\begin{array}{l}\text { Collection } \\
\text { frequency }\end{array}$ & $\begin{array}{c}\text { Sample } \\
\text { type }\end{array}$ & $\begin{array}{l}\text { Analysis } \\
\text { frequency }\end{array}$ \\
\hline \multicolumn{5}{|c|}{ C-746-S and C-746-T landfill runoff } \\
\hline $\begin{array}{l}\text { Location } 1 \text { (SW1), } \\
\text { Location } 2 \text { (SW45), } \\
\text { Location } 3 \text { (SW46) }\end{array}$ & $\begin{array}{c}\text { Chloride, sulfate, } \mathrm{pH}, \mathrm{Na}, \mathrm{U}, \mathrm{TOC}^{b} \\
\mathrm{TSS}^{c}{ }^{c} \mathrm{TDS}^{d}{ }^{\prime} \text { total solids, specific } \\
\text { conductivity, } \mathrm{Fe} \text {, dissolved solids }\end{array}$ & Quarterly & Grab & Quarterly \\
\hline
\end{tabular}

${ }^{a}$ See Fig. 7.2.

${ }^{b}$ Total organic carbon.

'Total suspended solids.

${ }^{d}$ Total dissolved solids. 


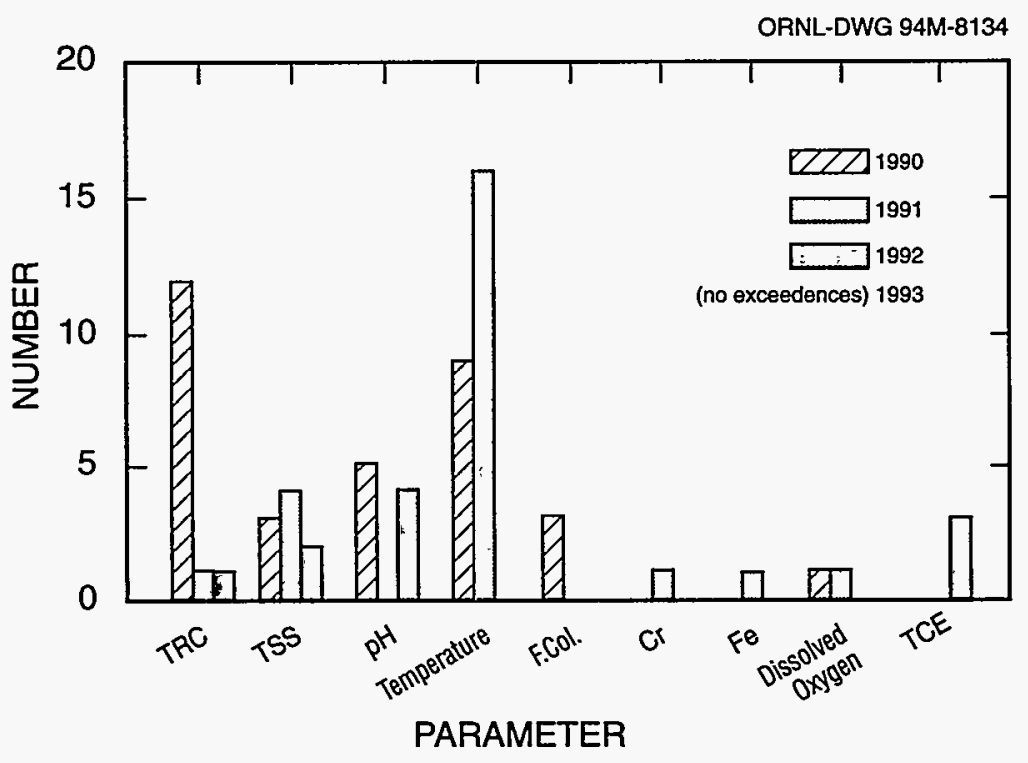

Fig. 7.3. KPDES exceedences, 1990-1993. (TRC = total residual chlorine; TSS = total suspended solids; F. Col. = fecal coliform; TCE = trichloroethylene.) 


\section{Nonradiological Environmental Surveillance}

W. D. Malis and M. G. White

\section{Abstract}

The purpose of the nonradiological environmental surveillance program at Paducah Gaseous Diffusion Plant (PGDP) is to assess the effects of PGDP operations on the site and the local environment and population. Surveillance includes analysis of air, surface water, groundwater (see Section 9), sediment, soil, vegetation, wildlife, and fish. Surveillance results indicated that radionuclide concentrations in most sampled media were within applicable standards.

Nonradiological environmental surveillance at the Paducah Gaseous Diffusion Plant (PGDP) involves sampling and analysis of air, surface water, sediment, soil, vegetation, fish, wildlife, and groundwater (see Section 9 for groundwater surveillance results). Surveillance activities are performed by the PGDP Environmental Monitoring Department.

\section{AMBIENT AIR}

PGDP maintains and operates an ambient air monitoring system to assess the impact of gaseous fluorides emitted by PGDP on ambient air. The results of data generated by the ambient air monitoring system are also used to demonstrate compliance with the ambient air quality standards for gaseous fluorides established by the Kentucky Division for Air Quality (KDAQ).

\section{Surveillance Program}

Ambient air is sampled continuously for gaseous fluorides at the following locations:

- $\quad$ plant north (PN), plant south (PS), plant east (PE), and plant west $(\mathrm{PW})$ within the plant fence;

- boundary north (BN), and boundary east $(\mathrm{BE})$ at the plant boundary;

- one north (1N), one south (1S), one west (1W), one east (1E), and one southeast (1SE) 1 mile outside the plant fence; and

- Grahamville (GR), the nearest community.

Figure 8.1 shows these locations.

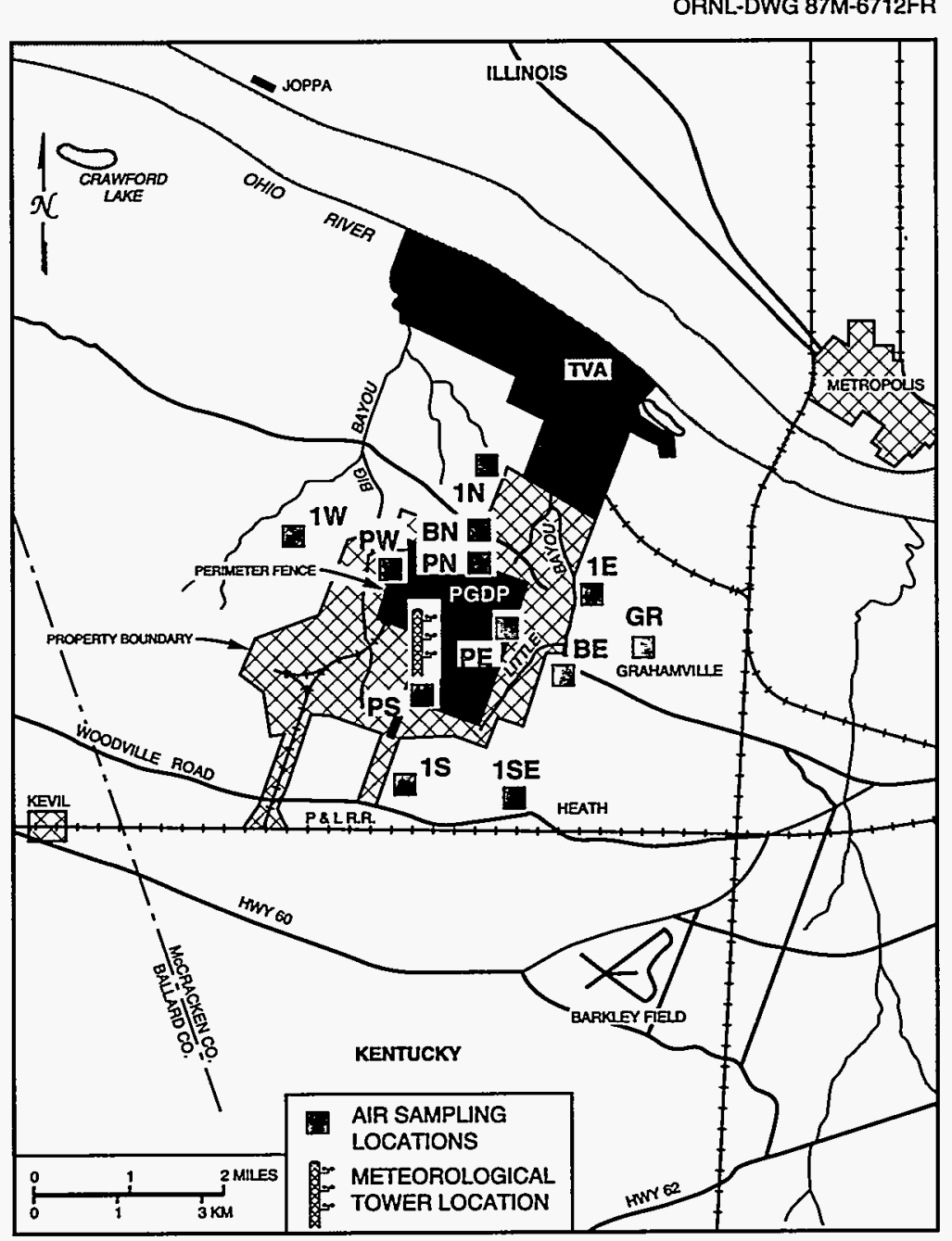

Fig. 8.1. Air sampling and meteorological monitoring stations at PGDP. 
The sample collectors (consisting of filters treated with sodium carbonate for ambient collection of fluorides) are exchanged and analyzed each week for fluoride concentrations. To ensure data accuracy, samples are not analyzed if a problem occurs causing the final sample flow to decrease more than $40 \%$ from the initial flow rate or if the sampler is found not running. Analysis is also not performed if upon opening the filter holder the analyst finds the filter cracked (Coker 1988). The filters are leached with water, and fluoride content is measured by specific ion electrode analysis (PGDP 1979). Results of the analyses are logged into a computer data base and are used to demonstrate compliance with KDAQ gaseous fluoride ambient air quality standards.

In response to the 1990 Tiger Team assessment, PGDP has proposed some improvements in the ambient air monitoring program. An ambient air monitoring plan has been developed to implement these improvements to the monitoring system. An engineering project was approved for the purchase of new monitoring equipment, which is being installed.

\section{Surveillance Results}

Table 8.1 provides a summary of the 1993 ambient air measurements for fluorides. All samples were well below the Kentucky ambient air quality standards for fluorides. The highest annual average for fluorides was $0.118 \mathrm{ppb}$ at the PN site. This concentration is well below the annual arithmetic mean standard of $500 \mathrm{ppb}$ for fluorides. The maximum weekly concentration of $0.572 \mathrm{ppb}$ at the PS location was $27 \%$ of the KDAQ secondary fluoride maximum weekly standard of $2 \mathrm{ppb}$.

Table 8.1. Environmental air sampling for fluorides at PGDP in 1993

\begin{tabular}{ccccc}
\hline & & & \multicolumn{3}{c}{$\begin{array}{c}\text { Concentration } \\
\text { Point }\end{array}$} & $\begin{array}{c}\text { No. of } \\
\text { samples }\end{array}$ & & $\mathrm{Av}^{d}$ \\
\cline { 3 - 5 } & & $\mathrm{Min}^{b}$ & $\mathrm{Max}^{c}$ & 0.118 \\
\hline PN & 53 & 0.052 & 0.400 & 0.088 \\
PE & 47 & 0.051 & 0.420 & 0.089 \\
PS & 52 & 0.052 & 0.572 & 0.082 \\
PW & 53 & 0.053 & 0.483 & 0.072 \\
BN & 51 & 0.051 & 0.153 & 0.063 \\
BE & 48 & 0.048 & 0.124 & 0.061 \\
IN & 49 & 0.050 & 0.114 & 0.056 \\
IE & 51 & 0.049 & 0.129 & 0.058 \\
ISE & 52 & 0.049 & 0.085 & 0.057 \\
1S & 51 & 0.048 & 0.096 & 0.062 \\
1W & 51 & 0.049 & 0.129 & 0.063 \\
GR & 51 & 0.053 & 0.111 &
\end{tabular}

${ }^{a}$ See Fig. 8.1.

${ }^{b}$ Several samples at every location were below detection limits. In these cases, the detection limit is used as the minimum value.

'Kentucky secondary air quality standard (401 KAR 53:010) for maximum one-week average is $2.0 \mathrm{ppb}$ as hydrogen fluoride.

${ }^{d}$ Kentucky primary air quality standard (401 KAR 53:010) for annual arithmetic mean is $500 \mathrm{ppb}$. 


\section{SURFACE WATER}

SW13, the north/south diversion ditch (see Fig. 8.2), is monitored weekly. This ditch receives coal-pile runoff and $\mathrm{C}-400$ decontamination solution filtrate. Grab samples were analyzed for the weekly parameters listed in Table 8.2. Each week a $100-\mathrm{mL}$ sample is poured into a yearly composite container. At the end of each year, the composite sample is analyzed for the annual parameters listed in Table 8.2. (Because these data are not used for comparison with regulatory limits, the fact that holding times are exceeded is not of concern.)

Monthly sampling is conducted at upstream Big Bayou Creek (SW1), upstream Ohio River (SW29), and downstream Ohio River (SW30). Figure 8.2 shows the sampling locations. Samples that were analyzed for 1,2-dichloroethane, discharged by an upstream Ohio River industrial complex, were $<1 \mu \mathrm{g} / \mathrm{L}$, unchanged from 1992.

\section{Surveillance Results}

Typical comparisons used

elsewhere in this report are not possible for the surveillance locations and analyses listed in Table 8.2. These locations have no background, or reference, locations that can be used for comparison. These locations are monitored to maintain data that could possibly be used to explain or trace unusual results at other plant locations. These data can be compared from year to year to determine if significant changes have occurred. Data were first compared visually to the previous year, and those with potential differences were analyzed using a two-tailed $t$-test. The two-tailed test was used because differences either below or above last year's levels were of interest.

Locations SW29 and SW30, both involving Ohio River water, are monitored to obtain information on any unusual resuits that could show up in plant water and Kentucky Pollutant Discharge Elimination System (KPDES) discharges. Ohio River water is used in the water treatment plant to provide potable, fire, and cooling water for the plant. SW29 is above where PGDP effluent discharges into the Ohio River through Big Bayou Creek. SW30 is below the location where Big Bayou Creek discharges into the Ohio River. Compared to 1992 data, 1993 data show significant elevations in chloride, fluoride, and sulfate at both SW29 and SW30.

Location SW13 is monitored to provide information on discharges from the chemical cleaning building, $\mathrm{C}-400$, and the steam plant, C-600. Because this location eventually discharges through KPDES 001 sampling point, these data are used to investigate any problems at 001 . Monitoring at this location will be discontinued in 1994. Statistical calculations were performed on chloride, fluoride, sulfate, and flow; chloride levels were significantly lower than 1992 levels, whereas the flows were significantly higher. The sulfate and fluoride levels showed no change. 
Table 8.2. Collection and analysis frequencies of surface water samples at PGDP in 1993

\begin{tabular}{|c|c|c|c|c|}
\hline Station $^{a}$ & Parameter & $\begin{array}{l}\text { Collection } \\
\text { frequency }\end{array}$ & Sample type & $\begin{array}{l}\text { Analysis } \\
\text { frequency }\end{array}$ \\
\hline SW29 & $\mathrm{NO}_{3}-\mathrm{N}, \mathrm{SO}_{4}$ chloride, $\mathrm{Cr}^{6+}, \mathrm{pH}, \mathrm{PO}_{4}-\mathrm{P}$ & Monthly & Grab & Monthly \\
\hline SW30 & $\begin{array}{l}\mathrm{NO}_{3}-\mathrm{N}, \mathrm{SO}_{4} \text { chloride, } \mathrm{Cr}^{6+}, \mathrm{pH}, \mathrm{PO}_{4}-\mathrm{P}, \\
\text { 1,2-dichloroethane }\end{array}$ & Monthly & Grab & Monthly \\
\hline SW13 & $\begin{array}{l}\mathrm{NO}_{3}-\mathrm{N}, \mathrm{PO}_{4}-\mathrm{P} \text {, chloride, } \mathrm{Cr}^{6+}, \mathrm{pH}, \\
\mathrm{F}^{-}, \mathrm{SO}_{4} \text {, temperature }\end{array}$ & Weekly & $\begin{array}{l}\text { Grab and 7-day } \\
\text { composite }\end{array}$ & Weekly \\
\hline SW13 & $\begin{array}{l}\mathrm{Ni}, \mathrm{Hg}, \mathrm{Cd}, \mathrm{As}, \mathrm{Ba}, \mathrm{Cu}, \mathrm{Pb}, \mathrm{Se}, \mathrm{Ag} \\
\mathrm{Cr}, \mathrm{ICP}^{b} \text { metals scan }\end{array}$ & Annually & $\begin{array}{l}\text { Annual } \\
\text { composite }\end{array}$ & Annually \\
\hline SW1 & $\begin{array}{l}\mathrm{NO}_{3}-\mathrm{N}, \mathrm{SO}_{4} \text { chloride, } \mathrm{Cr}^{6+}, \mathrm{pH}, \mathrm{PO}_{4}-\mathrm{P}, \\
\mathrm{F}^{-} \text {, weekly temperature }\end{array}$ & Monthly & Grab & Monthly \\
\hline
\end{tabular}

${ }^{a}$ See Fig. 8.2.

'Inductively coupled plasma spectrometer.

Location SW1, upstream Big Bayou Creek, is located above all PGDP discharges. Data are collected at this location for reference to other programs on plant effluents. Chloride, sulfate, and fluoride were evaluated statistically; none of these analyses were significantly different from 1992 data.

SEDIMIENT

The stream bottom is an important constituent of the aquatic environment. If a pollutant is a suspended solid or is attached to suspended sediment, it can settle to the bottom (thus creating the need for sediment sampling), be filtered by certain organisms, or become attached to plant surfaces. Pollutants in solution can adsorb on suspended organic and inorganic solids or be assimilated by plants and animals. The suspended solids, dead biota, or excreta settle to the bottom and become part of the organic substrata that support the bottom-dwelling community of organisms. Figure 8.3 shows possible exposure routes of trace metals in an aquatic ecosystem (Jinks and Eisenbud 1972).
ORNL-DWG 86M-9977R2

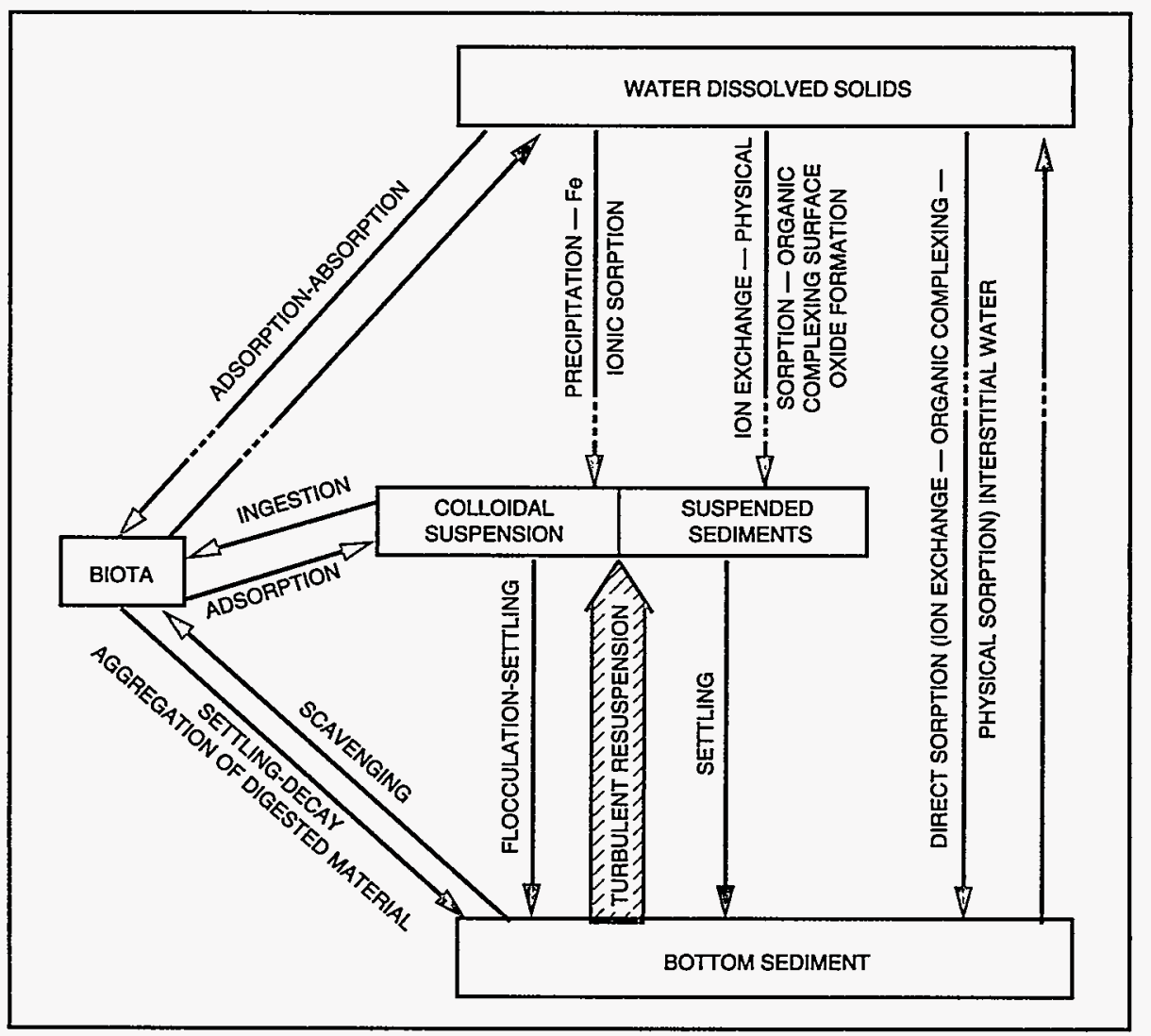

Fig. 8.3. Routes of trace metals in an aquatic ecosystem. Source: Jinks and Eisenbud. 1972. "Concentration Factors in Aquatic Environment," Radia. Data Rep., $13,243$. 
Sediments play a significant role in aquatic ecology by serving as a repository for chemical substances that pass via bottom-feeding biota to the higher trophic levels. Soluble pollutants introduced into a body of water reach the bottom sediment primarily by adsorption on suspended solids that later deposit on the bottom. The deposited remains of biota that have absorbed pollutants may also be an important source of chemical pollutants that enter the food chain.

\section{Surveillance Program}

The nonradiological surveillance program focuses on monitoring 35 metals and polychlorinated biphenyls (PCBs). Sediment samples were taken from six locations (see Fig. 8.4). At each location, a clean sampling scoop is used to obtain a sample from the bottom of the stream, taking as few rocks as possible. About $2 \mathrm{~kg}$ ( $4.5 \mathrm{lb}$ ) of sediment is placed in a new plastic bag. The samples are then dried and delivered to the analytical laboratory. Table 8.3 lists the collection and analysis frequencies for sediment and soil samples.
ORNL-DWG 87M-6712BR4

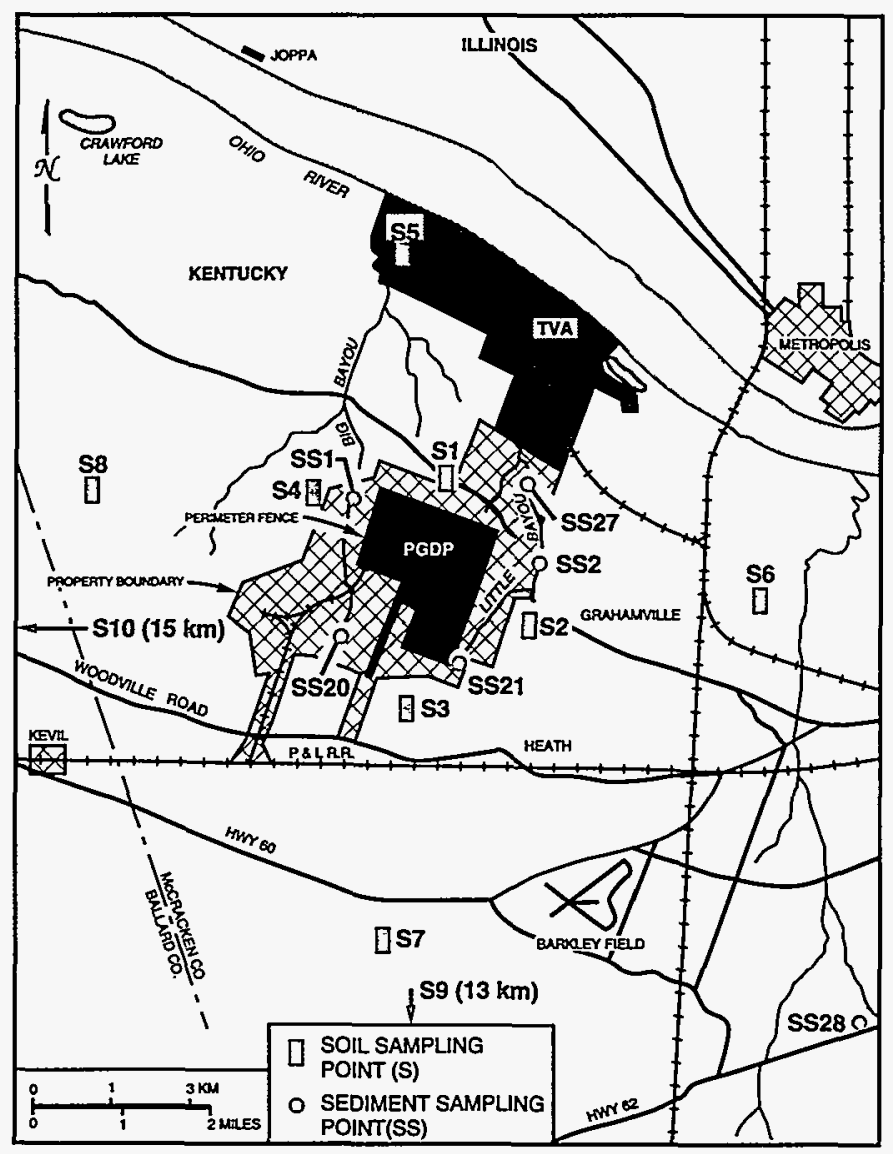

Fig. 8.4. Soil and sediment sampling locations at PGDP.

Table 8.3. Collection and analysis frequencies of soil and sediment samples at PGDP for 1993

\begin{tabular}{|c|c|c|c|c|}
\hline Station $^{a}$ & Parameter & $\begin{array}{l}\text { Collection } \\
\text { frequency }\end{array}$ & $\begin{array}{c}\text { Sample } \\
\text { type }\end{array}$ & $\begin{array}{l}\text { Analysis } \\
\text { frequency }\end{array}$ \\
\hline \multicolumn{5}{|c|}{ Soil } \\
\hline $\begin{array}{l}\text { S1, S2, S3, S4, S5, } \\
\text { S6, S7, S8, S9, } \\
\text { S10 }\end{array}$ & $\begin{array}{l}\mathrm{PCB}, \mathrm{Ag}, \mathrm{Al}, \mathrm{Ba}, \mathrm{Be}, \mathrm{Bi}, \mathrm{Ca}, \mathrm{Cd} \\
\text { Co, } \mathrm{Cr}, \mathrm{Cu}, \mathrm{Fe}, \mathrm{K}, \mathrm{Li}, \mathrm{Mg}, \mathrm{Mn} \\
\mathrm{Mo}, \mathrm{Na}, \mathrm{Nb}, \mathrm{Ni}, \mathrm{P}, \mathrm{Pb}, \mathrm{Ru}, \mathrm{Sb}, \mathrm{Si} \\
\text { Sn, Sr, Ta, Th, Ti, Tl, V, W, Zn, } \\
\mathrm{Zr}, \mathrm{As}\end{array}$ & Annually & Grab & Annually \\
\hline \multicolumn{5}{|c|}{ Sediment } \\
\hline $\begin{array}{l}\text { SS1, SS2, SS20, } \\
\text { SS21, SS27, SS28 }\end{array}$ & $\begin{array}{l}\mathrm{PCB}, \mathrm{Ag}, \mathrm{Al}, \mathrm{Ba}, \mathrm{Be}, \mathrm{Bi}, \mathrm{Cd}, \mathrm{Ca} \\
\mathrm{Co}, \mathrm{Cr}, \mathrm{Cu}, \mathrm{Fe}, \mathrm{K}, \mathrm{I}, \mathrm{Li}, \mathrm{Mg}, \mathrm{Mn} \\
\mathrm{Mo}, \mathrm{Na}, \mathrm{Nb}, \mathrm{Ni}, \mathrm{P}, \mathrm{Pb}, \mathrm{Ru}, \mathrm{Sb}, \mathrm{Si} \\
\text { Sn, } \mathrm{Sr}, \mathrm{Ta}, \mathrm{Th}, \mathrm{Ti}, \mathrm{Tl}, \mathrm{V}, \mathrm{W}, \mathrm{Zn} \\
\text { Zr, As }\end{array}$ & Annually & Grab & Annually \\
\hline
\end{tabular}

${ }^{a}$ See Fig. 8.4. 


\section{Surveillance Results}

Concentrations of arsenic above reference locations were detected at SS2, downstream Little Bayou Creek. Lead levels in all locations were higher this year and last year in both site and background locations than they have been in the past. Past data ranged from below reporting limits to approximately $30 \mathrm{mg} / \mathrm{kg}$ compared to 200 to $1000 \mathrm{mg} / \mathrm{kg}$ for 1993 . This increase was attributed to changes in analytical practices. Reanalysis of selected representative samples from 1993 confirmed the higher results. The analytical procedure change involved a more rigorous digestion probably resulting in the dissolution of lead not normally available to the environment. Because the effect was seen in both indicator and background locations, the change in reported levels does not indicate contamination by PGDP. No other significant increases for metal analyses above reference locations were detected. PCB was detected at SS2 at a level 2.9 times higher than 1992 levels. Past years' results for PCB at SS2 are shown in Table 8.4. This result confirms past studies in which PCB had been detected and signs were posted at Little Bayou Creek to make the public aware of PCB contamination. Big and Little Bayou creeks and KPDES-permitted discharge ditches have been investigated during administrative consent order activities. Remedial alternatives have been drafted (SAIC 1991) and are being reviewed by the U.S. Environmental Protection Agency and the Kentucky Department for Environmental Protection. When finalized, this document will become the record of decision under the Comprehensive Response, Compensation, and Liability Act in response to the administrative consent order.

\section{SOIL}

Soil is sampled to show any accumulation of airborne pollutants. Although sampling procedures are designed to minimize the well-known variability found in soils, the significance of individual units of data is small. If trends exist, data collected over a period of years may reveal them.

\section{Surveillance Program}

The nonradiological environmental surveillance program focuses on monitoring PCBs and 35 metals. Soil samples are taken annually at 10 locations-north, south, east, and west at the property boundary and at distances of $8 \mathrm{~km}$ (5 miles) beyond the property boundary (see Fig. 8.4). Remote (background) samples are taken at two locations 13 to $15 \mathrm{~km}$ ( 8.08 to 9.32 miles) from the plant. Each sampling site was selected because the soil appeared undisturbed or was known to have been undisturbed for several years. Two $1-\mathrm{m}^{2}\left(11-\mathrm{ft}^{2}\right)$ areas are

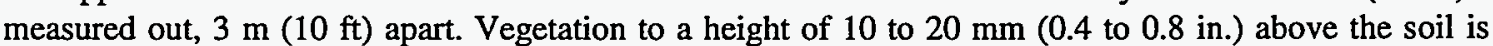
removed. Soil samples to a depth of $5 \mathrm{~cm}\left(2 \mathrm{in}\right.$.) are taken from the center and from each corner of the $1-\mathrm{m}^{2}$ area. The plugs of soil are composited into a labeled plastic bag. Table 8.3 lists sampling parameters and collection and analysis frequencies for soil.

\section{Surveillance Results}

No detectable concentrations of PCB were found in any of the samples collected in 1993. Concentrations of thallium above reference locations were detected in samples from S1, S3, and S5. Concentrations of manganese above reference locations were detected in samples from S3 and S6. Concentrations of thorium and bismuth above reference locations were also detected in samples from S1 and S6, respectively. Lead levels in all locations except S8 (this includes background locations) were higher than they have been in the past. This increase was attributed to changes in analytical practices. Reanalysis of selected representative samples from 1993 confirmed the higher results. The analytical procedure change involved a more rigorous digestion probably resulting in the dissolution of lead not normally available to the environment. Because the effect was seen in both indicator and background locations, the change in reported levels does not indicate contamination by PGDP. No other differences were apparent among samples from at or near the property boundary and those from remote locations.

\section{8-6 Nonradiological Environmental Surveillance}




\section{VEGETATION}

Vegetation (grass) samples are collected at 18 locations every three months. The samples are air-dried before being analyzed for fluorides. The primary objective of vegetation sampling is to determine the total fluorides in foliage for comparison with the fluoride-in-foliage section of the Kentucky air pollution regulation (401 KAR 53:010). This regulation states that fluoride measured in forage is not to exceed an average of $40 \mu \mathrm{g} / \mathrm{g}$ over the growing season, $60 \mu \mathrm{g} / \mathrm{g}$ for a two-month average, or $80 \mu \mathrm{g} / \mathrm{g}$ for a one-month average (dry weight).

Figure 8.5 shows the grass sampling locations. These locations represent the perimeter fence, property boundary, and 1.6- and 8-km (1- and 5-mile) distances as related to the primary emission point. Table 8.5 summarizes the analytical results.

Samples collected outside the fenced area are compared with the Kentucky ambient air quality standard of $60 \mu \mathrm{g} / \mathrm{g}$ for a two-month average (401 KAR 53:010). Samples taken outside the fenced areas ranged from less than 5.7 to $20.5 \%$ of the standard.

\section{TERRESTRIAL WHLLIFE AND FISH}

As a result of sporadic positive lead results obtained from deer sampling in 1992, the Western Kentucky Wildlife Management Area (WKWMA) was identified as warranting further testing by Martin Marietta Energy Systems, Inc. (MMES), the Kentucky Department of Fish and Wildlife, and the Corps of Engineers. The sampling and data interpretation were conducted on fish samples under the Martin Marietta Environmental Restoration program. No way exists to distinguish the generator of accrued contamination because the contaminants noted could have originated from past Kentucky Ordnance Works or MMES operations.

Although there is no evidence that MMES operations caused this problem, in compliance with U.S. Department of Energy (DOE) orders, MMES established an environmental monitoring program to monitor ambient conditions and the plant's effect on off-site emissions. DOE orders require risk, both radiological and chemical, to be characterized such that outside contributions are used in reporting dosage.

The sampling plan was designed to indicate contamination in the WKWMA's three most commonly used resources, specifically deer, fish, and rabbits. Fish sampling occurred in June 1993 and was conducted in the following areas: a gravel pit southeast of the production area, two ponds in the production area, and a background pond north of Ogden Landing Road. Bass and bluegill populations were sampled because they have 
Table 8.5. Fluoride in grass (dry weight) at PGDP for 1993 Growing season is April through September

\begin{tabular}{|c|c|c|c|c|c|c|c|}
\hline \multirow[b]{2}{*}{ Point ${ }^{a}$} & \multirow[b]{2}{*}{$\begin{array}{l}\text { No. of } \\
\text { samples }\end{array}$} & \multicolumn{5}{|c|}{$\begin{array}{c}\text { Concentration } \\
(\mu \mathrm{g} / \mathrm{g})\end{array}$} & \multirow[b]{2}{*}{$\begin{array}{l}\text { Percentage } \\
\text { of standard }\end{array}$} \\
\hline & & Min & $\operatorname{Max}$ & Annual Av & $\begin{array}{c}\text { Growing } \\
\text { season } \\
\mathrm{Av}\end{array}$ & Standard ${ }^{b}$ & \\
\hline G1 & 4 & 5.2 & 12.6 & 9.2 & 8.9 & $c$ & \\
\hline G2 & 4 & 3.7 & 12.7 & 8.2 & 8.2 & $c$ & \\
\hline G3 & 4 & 3.0 & 10.0 & 6.0 & 5.5 & $c$ & \\
\hline G4 & 4 & $<3.0^{d}$ & 9.3 & $<6.2$ & $<6.3$ & $c$ & \\
\hline G5 & 4 & $<3.0$ & 8.9 & $<5.8$ & $<6.2$ & 60 & $<10.3$ \\
\hline G6 & 4 & $<3.0$ & 9.1 & $<5.4$ & $<6.1$ & 60 & $<10.2$ \\
\hline G7 & 4 & 3.0 & 7.7 & 5.6 & 6.1 & 60 & 10.2 \\
\hline G8 & 4 & $<3.0$ & 8.9 & $<5.8$ & $<6.2$ & 60 & $<10.3$ \\
\hline G9 & 4 & 3.1 & 10.2 & 6.0 & 6.7 & 60 & 11.2 \\
\hline G10 & 4 & 3.1 & 10.0 & 5.8 & 6.6 & 60 & 11.0 \\
\hline G11 & 4 & $<3.0$ & 7.0 & $<4.9$ & $<5.5$ & 60 & $<9.2$ \\
\hline G12 & 4 & $<3.0$ & 4.2 & $<3.7$ & $<3.4$ & 60 & $<5.7$ \\
\hline G13 & 4 & 4.0 & 8.3 & 5.2 & 4.1 & 60 & 6.8 \\
\hline G14 & 4 & $<3.0$ & 8.1 & $<5.5$ & $<7.0$ & 60 & $<11.7$ \\
\hline G15 & 4 & 5.0 & 16.1 & 9.1 & 12.3 & 60 & 20.5 \\
\hline G16 & 4 & $<3.0$ & 7.1 & $<8.1$ & $<6.0$ & 60 & $<10.0$ \\
\hline G17 & 4 & $<3.0$ & 11.8 & $<8.0$ & $<6.7$ & 60 & $<11.2$ \\
\hline G18 & 4 & 4.0 & 5.5 & 4.8 & 5.0 & 60 & 8.3 \\
\hline
\end{tabular}

${ }^{a}$ See Fig. 8.5.

${ }^{b}$ Kentucky ambient air quality standards (401 KAR 53:010): fluoride measured on forage is not to exceed an average of $40 \mu \mathrm{g} / \mathrm{g}$ over the growing season, $60 \mu \mathrm{g} / \mathrm{g}$ for a two-month average, or $80 \mu \mathrm{g} / \mathrm{g}$ for a one-month average (dry weight).

'Sampling locations are on government property inside the plant security fence.

dLower limit of detection is $3 \mu \mathrm{g} \mathrm{F} / \mathrm{g}$.

reproducing populations. Catfish were not sampled because they are stocked yearly and are suspected to have very little carryover from year to year. Department of Fish and Wildlife personnel conducted the sampling and were accompanied by PGDP personnel. Samples were split by cutting fish specimens into filets, one filet to Fish and Wildlife personnel and one to PGDP personnel for analysis. The state then analyzed the samples while PGDP, with the assistance of Oak Ridge National Laboratory, analyzed the duplicates. The state also analyzed a composite of each fish type from each pond.

Oak Ridge National Laboratory data, received in September 1993, revealed certain mercury concentrations higher than the U.S. Food and Drug Administration action level of $1 \mathrm{ppm}$. The data were compared with CH2M Hill's Phase I sampling and agreed in both level and trophic level expectations. The mercury data and the risk information were reported in Phase I documents. Analyses performed by state laboratories, received in October 1993, agreed with both sets of data.

No apparent pathway exists for PGDP contaminants to enter the southern ponds or the north pond at the WKWMA. The only direct link currently noted is the use of rubble from PGDP. The rubble was used to build 
levees at some of the ponds. CH2M Hill Phase I documents did not, however, show detectable mercury in any of the 84 soil borings, 18 surface soils, 14 surface waters, or 8 sediments sampled. One sediment location corresponded to the north pond sampled in June 1993. There were 3 groundwater detections out of 86 samples and 9 biota detections from 92 samples. PGDP data reviews have shown occasional positive results for mercury in surface water. These levels were low but may become significant with a high bioaccumulation factor. Plant sediments and soil data show four main areas where elevated concentrations of mercury have been found: KPDES 001, KPDES 011, the C-615 digester sludge, and the sanitary and inert landfill soil, none of which could have contributed to the contamination.

Following data evaluation, a meeting was held at the Department of Fish and Wildlife Game Farm in Frankfort to determine further actions necessary in response to the fish data. Representatives from the Department of Fish and Wildlife, the Division of Water, and the Cabinet for Human Resources (CHR), as well as from the state Agreement In Principle and PGDP, were present. The first three agencies maintained the responsibility for determining if an advisory was warranted for Kentucky wildlife. The following decisions were reached:

- A $1.0 \mathrm{ppm}$ U.S. Food and Drug Administration limit was used to make any determination.

- All ponds and background locations were resampled to verify previous data as well as to gather data on unsampled ponds, resulting in 11 discrete sampling locations. Overflow ponds were treated as one source. Filets were taken from three species, specifically, bass, bluegill, and channel catfish. The analyses were based on a blended composite from each type of fish at each pond. The CHR and the Kentucky Disaster and Emergency Services labs provided duplicate analyses.

- Resampling started on October 5, 1993, and was completed in a couple of weeks. A portion of the samples was reserved to settle discrepancies.

- The state was responsible for making a decision following data evaluation, with PGDP maintaining no responsibility in the resampling.

Analytical data from the state laboratories and the MMES laboratory agreed. The CHR posted signs at various ponds that were sampled to notify the public that mercury had been found in some of the bass analyzed. Data comparisons are shown in Table 8.6. No further action will be necessary by DOE.

In August 1993, eight deer were harvested in the WKWMA to monitor the effects of PGDP operations on the ecology of the surrounding area. In 1993, two deer obtained from the Ballard County Wildlife Management Area were used for reference. Liver and muscle samples were analyzed for metals and PCBs; fat samples were also analyzed for PCBs. The liver, muscle, and fat tissue are evaluated for risks if analyses reveal detectable levels above background, or reference, deer because these types of tissues are considered consumable by hunters. The results for all detected analytes in liver and muscle samples are summarized in Tables 8.7 and 8.8, respectively.

Analytical data on concentrations of PCBs and 28 metals were also evaluated. Because all PCB concentrations were below the reporting limits, no evaluation was made of potential PCB intake. Nine metals are listed in Tables 8.7 and 8.8 for liver and muscle tissue. Eight metals were selected from the list of 28 because they are potentially dischargeable from PGDP and as such are listed on the KPDES permit. Mercury was also included this year because cooperative fish sampling results on the WKWMA detected mercury contamination. These results are discussed in the section on fish. A few sources of mercury are on the plant site, and mercury has been detected in some internal sediment locations. Detectable levels, significantly higher than background, were not seen in liver or muscle tissue. Also present were detectable levels of $\mathrm{Ca}, \mathrm{Mg}, \mathrm{P}, \mathrm{Na}$, and $\mathrm{Li}$. Because these minerals are normally present in animal tissue, no additional evaluations were made. Other elements were seen in reservation, or indicator, deer that were not seen in background deer. The following elements had reportable results (the number in parentheses is the reportable results out of eight samples):

\begin{tabular}{lc} 
Liver & Muscle \\
\hline $\mathrm{Ag}(1)$ & None \\
$\mathrm{Se}(1)$ & \\
$\mathrm{Sr}(3)$ & \\
$\operatorname{Mo~(6)}$ & \\
\hline
\end{tabular}


Table 8.6. Mercury in fish-West Kentucky Wildlife Management Area comparisons Results in $\mathrm{mg} / \mathrm{kg}(\mathrm{ppm})$

\begin{tabular}{|c|c|c|c|c|}
\hline \multirow{2}{*}{$\begin{array}{l}\text { Location and } \\
\text { species }\end{array}$} & \multirow[b]{2}{*}{ CH2M Hill 1989} & \multicolumn{2}{|c|}{ Split samples } & \multirow{2}{*}{$\begin{array}{l}\text { State resample } \\
\text { composite }\end{array}$} \\
\hline & & MMES 1993 & $\begin{array}{l}\text { State } 1993 \\
\text { composite }\end{array}$ & \\
\hline $\begin{array}{l}\text { New Pond } \\
\text { bass }\end{array}$ & $0.21 \mathrm{U}$ & $\begin{array}{l}0.50,0.61,0.45,1.26,0.54 \\
\mathrm{Av}=0.67\end{array}$ & 1.04 & $0.59 / 0.83^{a} \mathrm{DES}^{b}$ \\
\hline $\begin{array}{l}\text { New Pond } \\
\text { bluegill }\end{array}$ & NA & $\begin{array}{l}0.35,0.16,0.32,0.37,0.14 \\
\mathrm{Av}=0.27\end{array}$ & NA & $0.20 \mathrm{CHR}$ \\
\hline $\begin{array}{l}\text { Horseshoe Pond } \\
\text { bass }\end{array}$ & 0.72 & $\begin{array}{l}0.56,0.67,0.45,1.46,0.23 \\
\mathrm{Av}=0.67\end{array}$ & 0.53 & $0.59 / 0.83^{a} \mathrm{DES}$ \\
\hline $\begin{array}{l}\text { Horseshoe Pond } \\
\text { bluegill }\end{array}$ & $0.29 \mathrm{U}^{c}$ & $\begin{array}{l}0.23,0.23,0.27,0.21,0.24 \\
\mathrm{Av}=0.24\end{array}$ & 0.25 & $0.20 \mathrm{CHR}$ \\
\hline $\begin{array}{l}\text { Gravel pit } 2 \\
\text { bass }\end{array}$ & NA & 0.56 & 0.53 & $0.26 / 0.30 \mathrm{DES}$ \\
\hline $\begin{array}{l}\text { Gravel pit } 2 \\
\text { bluegill }\end{array}$ & NA & $\begin{array}{l}0.15,0.29,0.29,0.50,0.16 \\
A v=0.28\end{array}$ & 0.28 & $0.19 \mathrm{CHR}$ \\
\hline $\begin{array}{l}\text { Metzger's Pond } \\
\text { bass }\end{array}$ & $0.99(1.5)$ & $\begin{array}{l}1.24,0.84,0.37,0.47,0.44 \\
\mathrm{Av}=0.67\end{array}$ & 0.68 & $0.81 \mathrm{CHR}$ \\
\hline $\begin{array}{l}\text { Metzger's Pond } \\
\text { bluegill }\end{array}$ & NA & $\begin{array}{l}0.15,0.31,0.36,0.33,0.35 \\
\mathrm{Av}=0.30\end{array}$ & 0.35 & 0.15 DES \\
\hline
\end{tabular}

Result comes from a composite sample from Horseshoe, Box Factory, Gravel pit 1, and New ponds, which are located near each other and are expected to co-mingle. Resample results are therefore listed for both New and Horseshoe ponds.

${ }^{b}$ Kentucky Disaster and Emergency Services.

${ }^{\circ} \mathrm{CH} 2 \mathrm{M}$ Hill results for panfish were listed as SF for sunfish, not bluegill. Results are assumed to be comparable. $\mathrm{U}=$ not detected at the level of the reported result. 
Table 8.7. PGDP 1993 annual deer harvest-analysis of liver tissue for inorganics

\begin{tabular}{|c|c|c|c|c|c|c|c|c|c|}
\hline \multirow[b]{2}{*}{ Deer } & \multicolumn{9}{|c|}{ Inorganic $(\mu \mathrm{g} / \mathrm{g})$} \\
\hline & $\mathrm{Al}$ & $\mathrm{Cd}$ & $\mathrm{Cr}$ & $\mathrm{Cu}$ & $\mathrm{Fe}$ & $\mathrm{Hg}$ & $\mathrm{Ni}$ & $\mathrm{Pb}$ & $\mathrm{Zn}$ \\
\hline \multicolumn{10}{|c|}{ Indicator deer } \\
\hline 1 & $a$ & $a$ & $a$ & 48 & 81 & 0.31 & $a$ & $a$ & 33 \\
\hline 2 & $a$ & $a$ & $a$ & 31 & 89 & 0.074 & $a$ & $a$ & 31 \\
\hline 3 & $a$ & $a$ & $a$ & 42 & 180 & $a$ & $a$ & $a$ & 32 \\
\hline 4 & $a$ & $a$ & $a$ & 34 & 79 & 0.093 & $a$ & $a$ & 42 \\
\hline 5 & $a$ & 0.12 & $a$ & 40 & 88 & 0.071 & $a$ & $a$ & 41 \\
\hline 6 & $a$ & 0.20 & $a$ & 110 & 85 & $a$ & $a$ & $a$ & 33 \\
\hline 7 & $a$ & 0.12 & $a$ & 57 & 55 & 0.008 & $a$ & $a$ & 28 \\
\hline 8 & $a$ & $a$ & $a$ & 25 & 85 & 0.043 & $a$ & $a$ & 38 \\
\hline \multicolumn{10}{|c|}{ Background deer } \\
\hline 9 & $a$ & 0.088 & $a$ & 23 & 93 & 0.16 & $a$ & $a$ & 46 \\
\hline 10 & $a$ & 0.12 & $a$ & 3 & 540 & 0.46 & $a$ & $a$ & 31 \\
\hline
\end{tabular}

Not detected.

Table 8.8. PGDP 1993 annual deer harvest-analysis of muscle tissue for inorganics

\begin{tabular}{|c|c|c|c|c|c|c|c|c|c|}
\hline \multirow[b]{2}{*}{ Deer } & \multicolumn{9}{|c|}{ Inorganic $(\mu \mathrm{g} / \mathrm{g})$} \\
\hline & $\mathrm{Al}$ & $\mathrm{Cd}$ & $\mathrm{Cr}$ & $\mathrm{Cu}$ & $\mathrm{Fe}$ & $\mathrm{Hg}$ & $\mathrm{Ni}$ & $\mathrm{Pb}$ & $\mathrm{Zn}$ \\
\hline \multicolumn{10}{|c|}{ Indicator deer } \\
\hline 1 & $a$ & $a$ & $a$ & 0.59 & 30 & 0.23 & $a$ & $a$ & 70 \\
\hline 2 & $a$ & $a$ & $a$ & 0.62 & 31 & 0.023 & $a$ & $a$ & 51 \\
\hline 3 & $a$ & $a$ & $a$ & 0.64 & 28 & 0.12 & $a$ & $a$ & 67 \\
\hline 4 & $a$ & $a$ & $a$ & 0.64 & 28 & $a$ & $a$ & $a$ & 68 \\
\hline 5 & $a$ & $a$ & $a$ & 0.60 & 25 & 0.19 & $a$ & $a$ & 71 \\
\hline 6 & $a$ & $a$ & $a$ & 0.69 & 37 & 0.32 & $a$ & $a$ & 59 \\
\hline 7 & $a$ & $a$ & $a$ & 0.69 & 31 & 0.089 & $a$ & $a$ & 55 \\
\hline 8 & $a$ & $a$ & $a$ & 0.50 & 30 & 0.00047 & $a$ & $a$ & 58 \\
\hline \multicolumn{10}{|c|}{ Background deer } \\
\hline 9 & $a$ & $a$ & $a$ & 0.86 & 36 & 0.29 & $a$ & $a$ & 57 \\
\hline 10 & 0.85 & $a$ & $a$ & 0.61 & 33 & 0.013 & $a$ & $a$ & 62 \\
\hline
\end{tabular}

${ }^{a}$ Not detected. 


\section{Groundwater}

\section{Abstract}

The primary objectives of groundwater monitoring at the Paducah site are to detect contamination and provide the basis for groundwater quality assessments if contamination is detected. Monitoring includes the exit pathways at the perimeter of the plant and off-site water wells. Primary off-site contaminants were determined to be trichloroethylene, an industrial degreasing solvent, and technetium-99, a fission by-product. A major finding for 1993 is the potential presence of degreasing-type agents on-site.

\section{INTRODUCTION}

Monitoring and protection of groundwater resources at Paducah Gaseous Diffusion Plant (PGDP) are required by federal and state regulations and by U.S. Department of Energy (DOE) orders. Federal groundwater regulations generally are enacted and enforced by the U.S. Environmental Protection Agency (EPA). PGDP lies within EPA Region IV jurisdiction. EPA Region IV encompasses the southeastern United States and maintains headquarters in Atlanta. Many state groundwater regulations are enacted and enforced by the Kentucky Division of Waste Management (KDWM) in Frankfort, Kentucky. A KDWM field office for western Kentucky is located in Paducah, Kentucky.

On discovery of off-site contamination from PGDP in 1988, the EPA and DOE entered into an administrative consent order (ACO). Under the Comprehensive Environmental Response, Compensation, and Liability Act (CERCLA) legislation, DOE was required to determine the nature and extent of off-site contamination through sampling of potentially affected wells and a comprehensive site investigation.

Groundwater monitoring at PGDP achieves compliance with one or more federal or state regulations and permit conditions and includes perimeter exit pathway monitoring and off-site water well monitoring. A more detailed description of groundwater monitoring is under "Groundwater Monitoring Program." Figures 9.1 through 9.6 show the locations of wells sampled during 1993. Selected graphs of analytical results are presented under "Groundwater Monitoring Results." Analytical results from the sampling described in this section are available on request from the PGDP Environmental Restoration and Waste Management (ERWM) Public Affairs Department.

The CERCLA/ACO site investigation, completed in 1991, determined off-site contaminants in the regional gravel aquifer to be trichloroethylene (TCE), an industrial degreasing solvent, and ${ }^{99} \mathrm{Tc}$, a fission by-product of the reprocessing of nuclear power reactor tails. Known or suspected sources of TCE include burial grounds, test areas, and other operating facilities. Likely ${ }^{99} \mathrm{Tc}$ sources are spills and leaks of contaminated TCE and leachate derived from contaminated scrap metal.

A major finding is the potential presence of dense nonaqueous phase liquids (DNAPLs) at three on-site locations. DNAPLs are liquids with densities greater than water (degreasing agents are common DNAPLs). DNAPLs typically have low solubilities in water and sink to the bottom of aquifers, forming pools and causing a continuing source of dissolved-phase pollution that is difficult to remove. The dissolved-phase groundwater contamination is migrating northward toward the Ohio River. Continued groundwater monitoring serves to identify the extent of contamination, predict the possible fate of the contaminants, and determine the movement of groundwater near PGDP.

\section{GROUNDWATER HYDROLOGY}

A portion of rainwater accumulates as groundwater by soaking into the ground, infiltrating soil and rock. The accumulation of groundwater in pore spaces of sediments creates sources of usable water. This groundwater flows in response to external forces. Groundwater eventually reappears at the surface in springs, swamps, stream and river beds, or pumped wells. Thus, the primary input to groundwater is recharge from rainwater infiltrating the soil, and the output of groundwater is discharge to springs, swamps, rivers, streams, and wells. 
ORNL-DWG 94M-6984

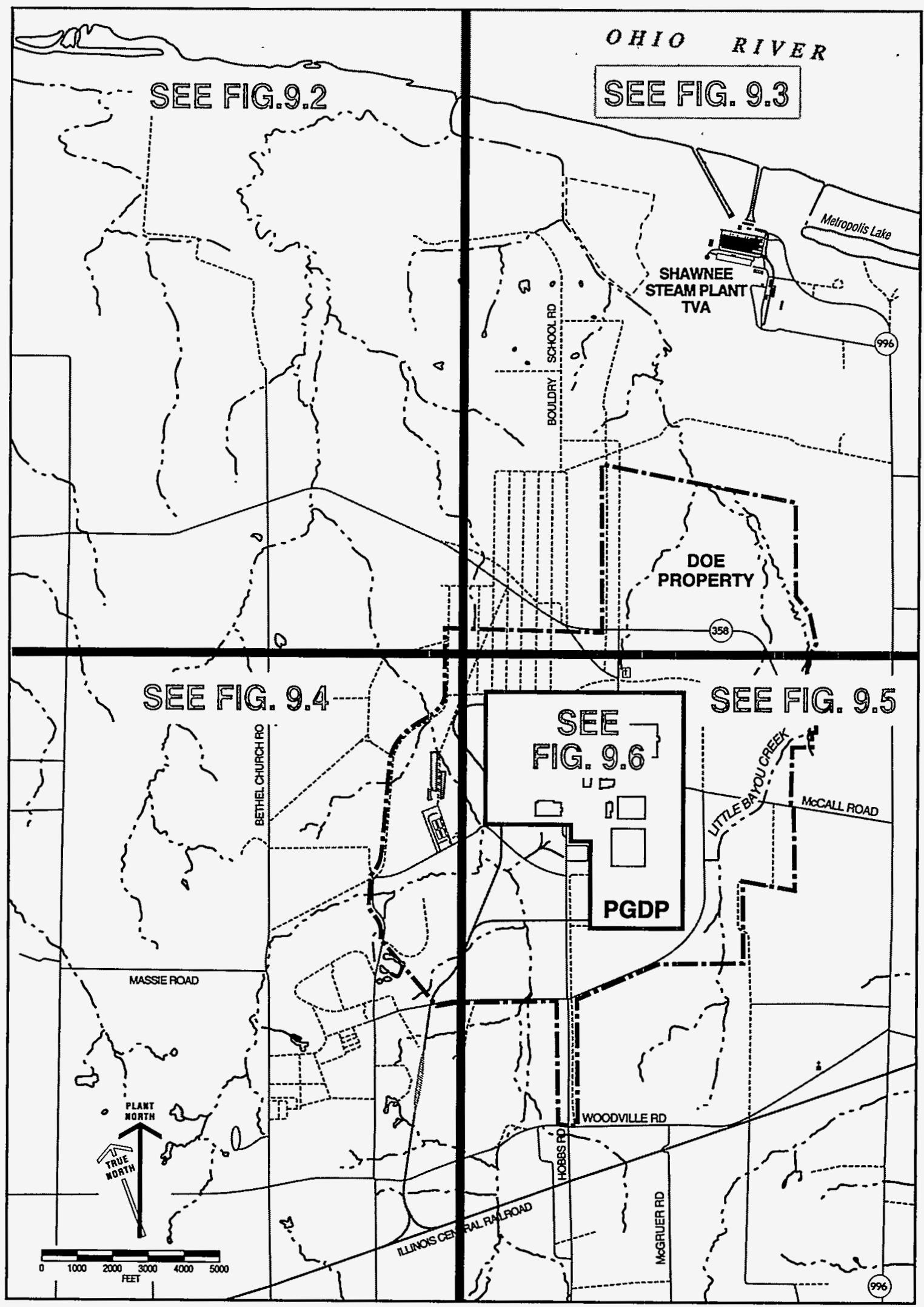

Fig. 9.1. Wells sampled by PGDP in 1993 (by sectors). 


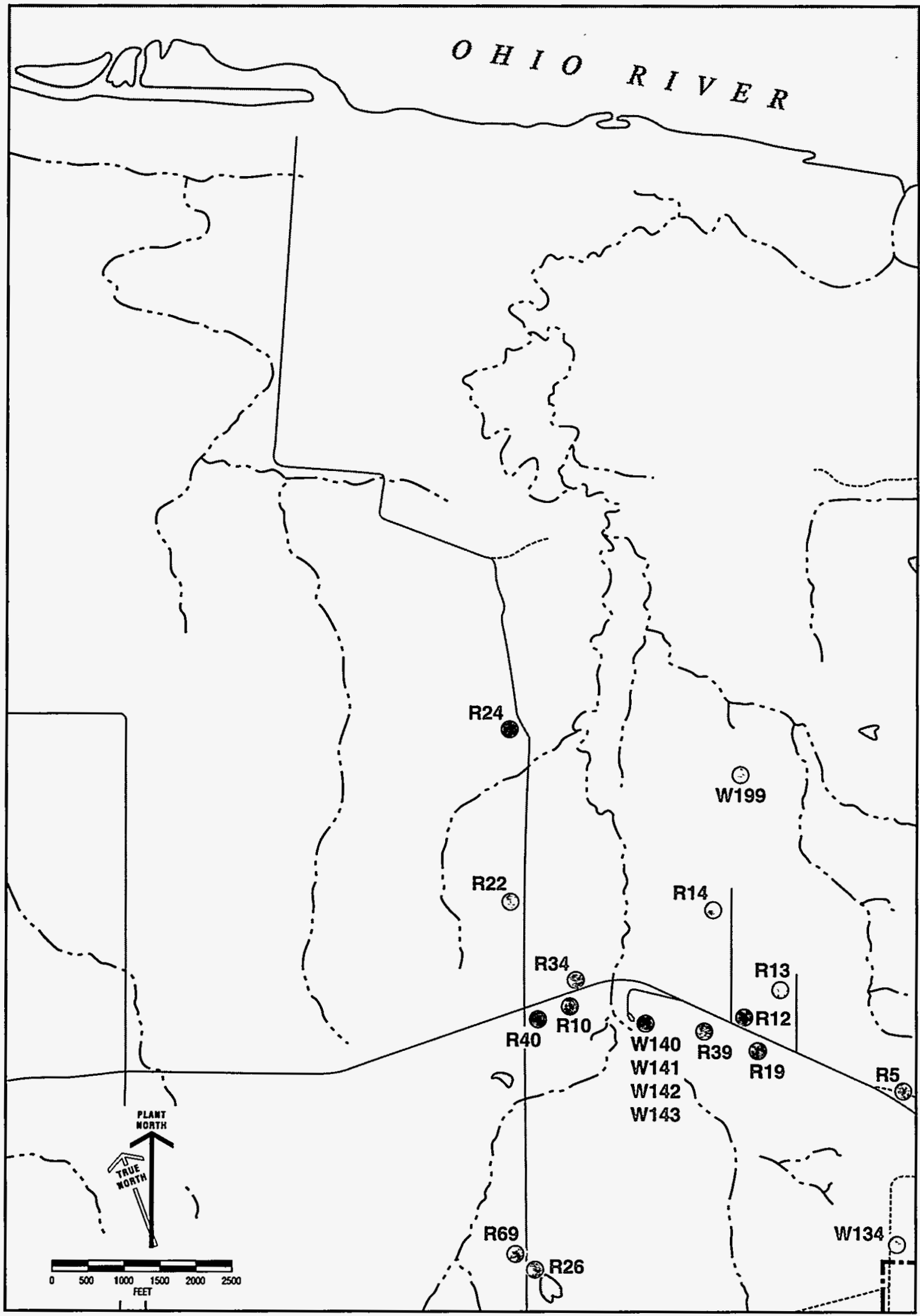

Fig. 9.2. Wells sampled by PGDP in 1993-northwest sector. 


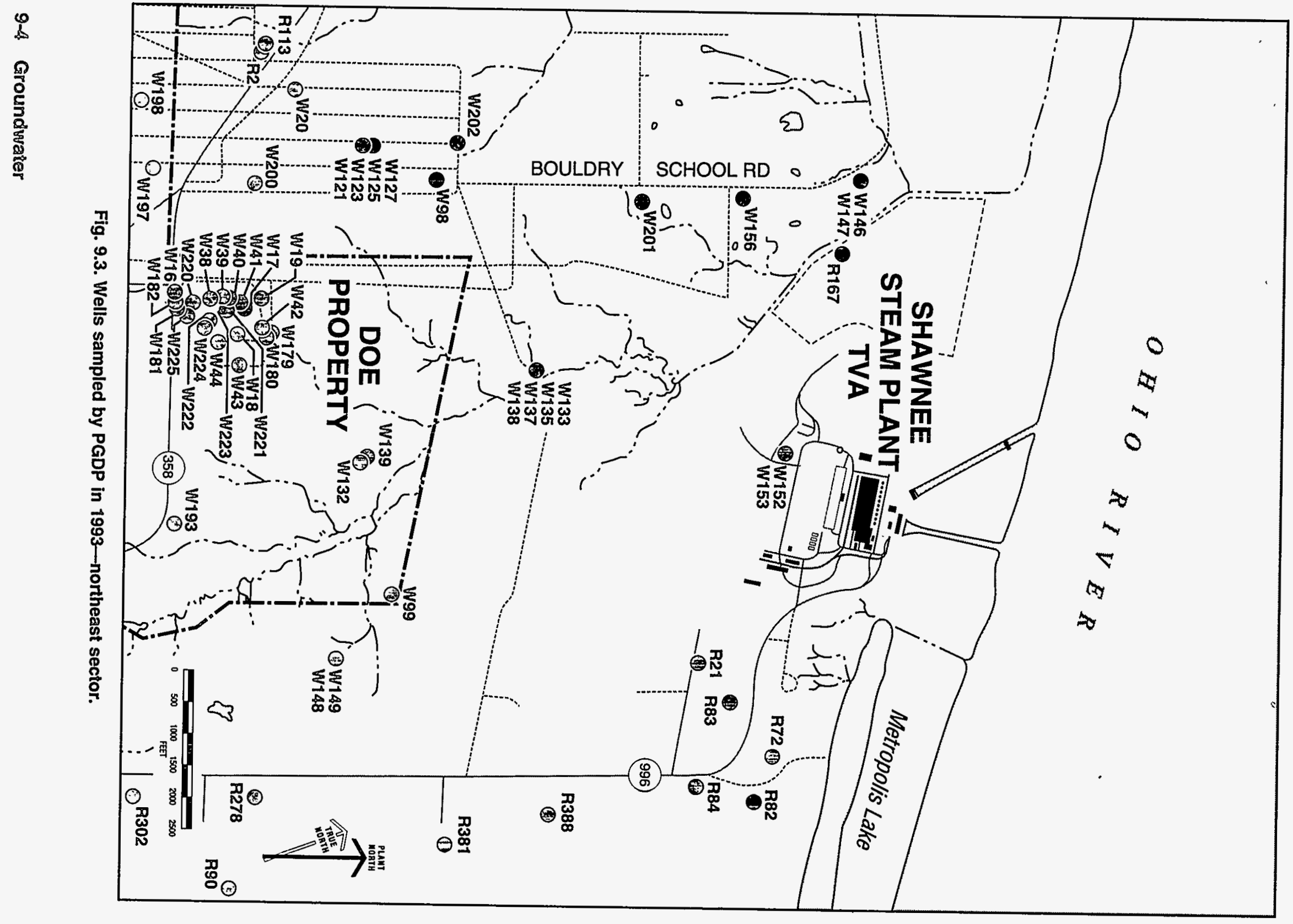


Annual Site Environmental Report

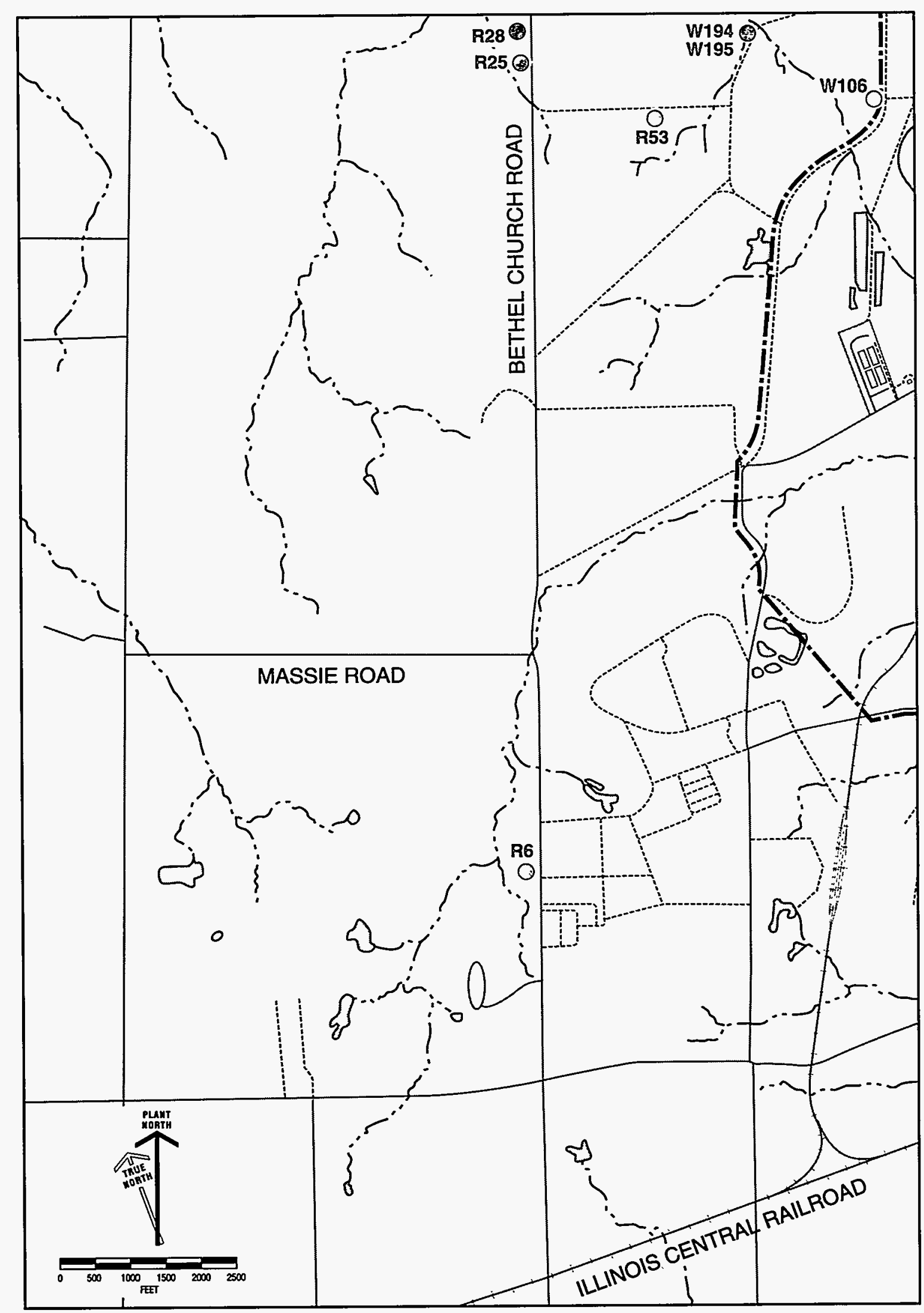

Fig. 9.4. Wells sampled by PGDP in 1993-southwest sector. 


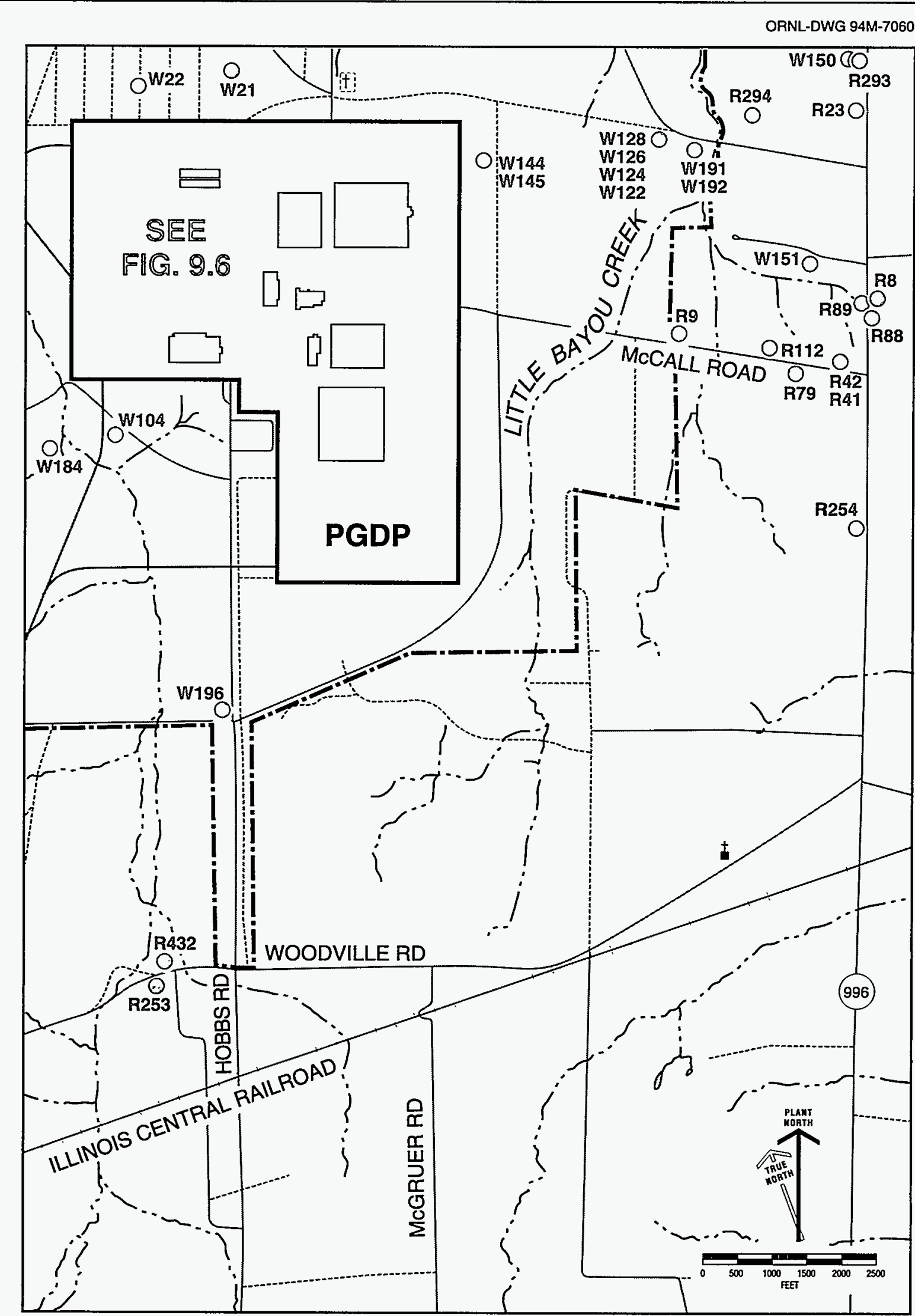

Fig. 9.5. Wells sampled by PGDP in 1993-southeast sector. 
ORNL-DWG 92M-7112R2

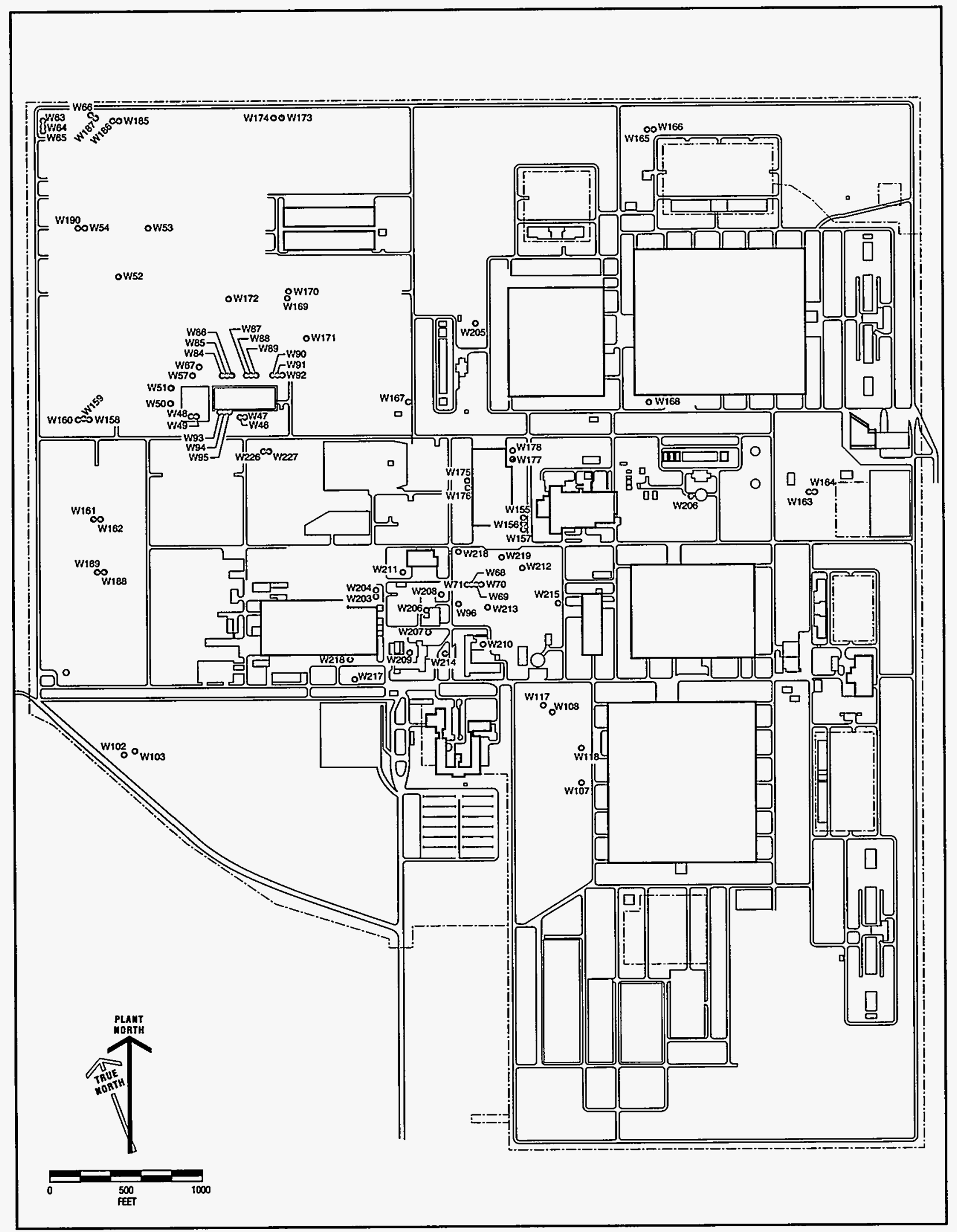

Fig. 9.6. Wells sampled by PGDP in 1993-plant site. 
Water from the surface moving down into the soil makes its way by percolating downward through the pore spaces between sediment grains. The smaller the pore spaces, the slower the flow of water through the pore spaces, and the slower the flow of water through the pore spaces, the slower the flow of water through the sediment. The physical property that describes the ease with which water can move through the pore spaces and cracks in a given material is called hydraulic conductivity. This conductivity is determined largely by the volume and size of the pore spaces and how well the pore spaces are connected, that is, the permeability.

As water infiltrates the earth, it travels down through the vadose, or unsaturated, zone; here the pore spaces are filled partly with water and partly with air. Water moving down through the unsaturated zone will eventually reach the saturated zone where the pore spaces are completely filled with water. The boundary between the unsaturated and the saturated zones is known as the water table, which usually, but not necessarily, follows a subtle contour of the surface topography. Springs, swamps, and beds of streams and rivers are the outcrops of the water table, where groundwater is discharged to the surface.

The flow of groundwater and the position of the water table may be complicated by variations in the permeability of the subsurface. Because the earth's permeability varies greatly, groundwater flowing through subsurface strata does not travel at a constant rate or without impediment. Strata that transmit water easily (such as those composed primarily of sand) are called aquifers, and strata that restrict water movement (such as clay layers) are called aquitards. An aquifer with an aquitard lying above and beneath it is called a confined aquifer. Groundwater moves through aquifers toward natural exits, or discharge points, to reappear at the surface.

The direction of groundwater flow through an aquifer system is determined by the permeability of the strata containing the aquifer and by the hydraulic gradient, which is a measure of the difference in hydraulic head over a specified distance. Differences in hydraulic head are the driving force for groundwater movement through the saturated zone. The hydraulic head at any given point in an aquifer is a function of the energy associated with the water's elevation above sea level and the pressures exerted on it by surrounding water. Because hydraulic head is not solely a function of elevation, downgradient is not necessarily synonymous with downhill.

The downgradient direction has a horizontal and vertical component, just as a household drain moves wastewater both horizontally and vertically, seeking the lowest point of exit. Aquitards deflect groundwater movement just as drainpipe walls control the direction of wastewater movement. In an aquifer constrained by aquitards such as horizontal clay layers, the downgradient direction tends to be more horizontal than vertical.

Groundwater aquifers are one of the primary pathways by which potentially hazardous substances may enter the environment. Substances placed in the soil may be dissolved in rainwater, which moves them downward through the unsaturated zone to the water table. The water then flows downgradient toward the discharge point.

Monitoring wells are used extensively to assess the effect of operations on groundwater quality, generally to determine the effect of a specific site on groundwater quality nearby. Wells positioned to intercept the groundwater flowing away from a site are called downgradient wells, and wells placed to intercept groundwater before it flows under a site are called upgradient wells. Any contamination of the downgradient wells not present in the upgradient wells at a site may be assumed to be a product of that site. Wells are drilled to various depths in the saturated zone below the area to be monitored. At the screened zone, the well casing is perforated to allow water to enter the well. Thus, the screened zone refers to the zone of subsurface strata where water is being sampled by the well. Figure 9.7 illustrates the construction of a monitoring well and the relationship between the screened zone and water elevation for wells screened below the water table. The water rises in the well casing to equilibrate with the hydraulic head of the water surrounding the well's screened zone. The elevation of this water in the well is measured to determine the hydraulic head of the water in the zone monitored. By comparing the water levels in adjacent wells screened in the same zone, a hydraulic gradient can be determined and the horizontal direction of groundwater flow can be predicted. Only wells screened in the same zones are considered when determining the horizontal gradient; wells screened above and below an aquitard can have different hydraulic heads, thus defining a vertical gradient.

The vertical direction of groundwater movement is controlled by the permeability of the aquitards and the relative difference in hydraulic head of the water on either side of an aquitard. Vertical gradients can be determined by comparing the water levels between adjacent wells screened on either side of an aquitard. If the water levels in deeper wells are higher than those in shallower wells, the vertical component of flow is upward.

Vertical and horizontal groundwater flow directions are in part determined by the permeability and continuity of geologic strata. To effectively monitor the movement of groundwater and any hazardous constituents it may contain, hydrogeologists at PGDP have undertaken many detailed studies of the geology of strata beneath the site.

\section{9-8 Groundwater}


ORNL-DWG 94M-7067

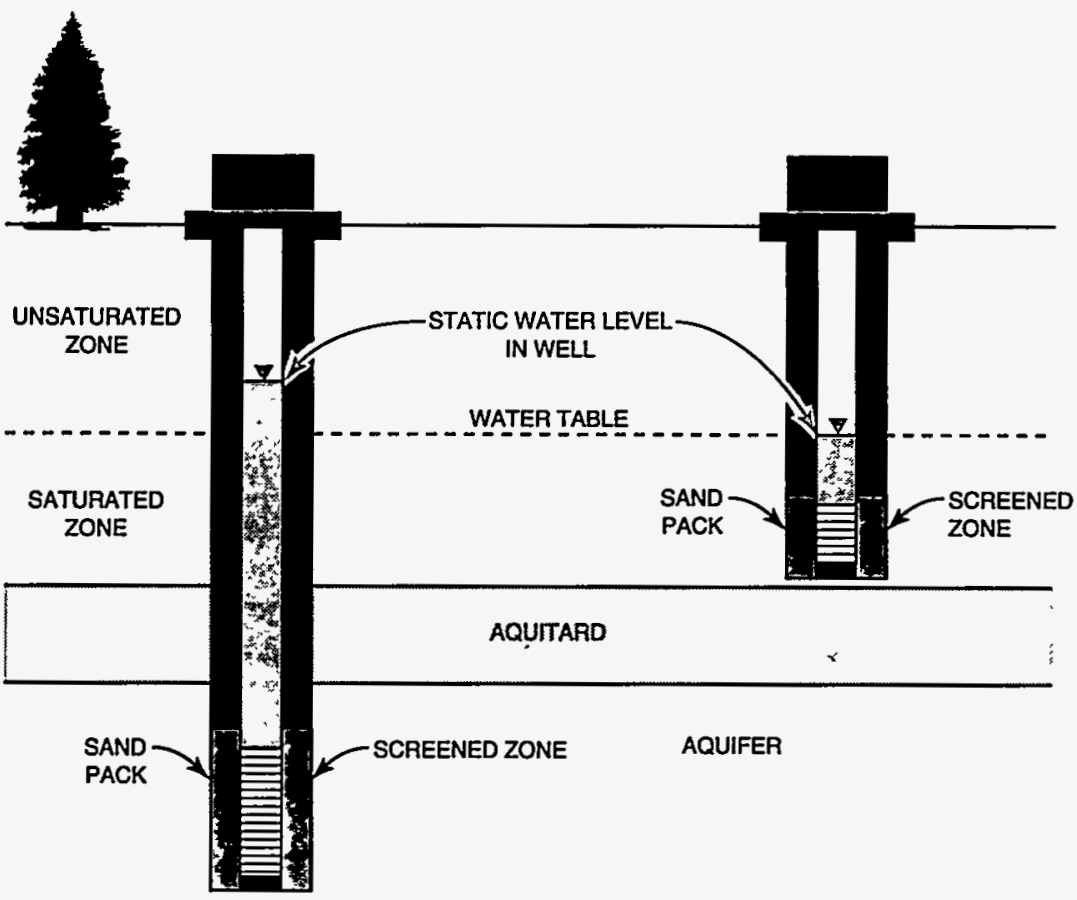

Fig. 9.7. Monitoring well construction showing relationship betweer screened zone and water level in well where the limited flow through the aquitard is upward.

\section{GEOLOGIC AND HYDROGEOLOGIC SETTING}

PGDP, located in the Jackson Purchase region of western Kentucky, lies within the northern tip of the Mississippi Embayment portion of the Gulf Coastal Plain Province. The Mississippi Embayment is a large sedimentary trough oriented nearly north-south that received sediments during the Cretaceous and Tertiary geologic periods.

In the PGDP area, bedrock is overlain by the Upper Cretaceous McNairy Formation, which consists of interbedded and interlensing sand, silt, and clay. Paleocene Porters Creek Clay occurs in the southern portions of the site above the McNairy Formation and predominantly consists of dark gray to black clay. Porters Creek Clay subcrops

along a buried terrace slope that extends east-west across the site. Eocene sediments, consisting of interbedded and interlensing sand, silt, and clay, overlie the Porters Creek Clay in the extreme southern end of the DOE reservation. The Cretaceous through Eocene strata dip gently to the south-southwest toward the axis of the embayment.

A unit designated as the Continental Deposits was laid down in the region during the late Tertiary and Quaternary periods, creating an angular unconformity with the underlying sediments. A basal gravel facies (lower Continental Deposits) and an upper, fine-grained clastic facies (upper Continental Deposits) are recognized in the Continental Deposits. The Continental Deposits are interpreted as originating from an alluvial fan that covered most of the Jackson Purchase region (Olive 1980).

In response to base-level changes during Pleistocene glaciations, stream systems eroded and later alluviated their valleys, reworking the Continental Deposits at different elevations. A thicker sequence of Pleistocene Continental Deposits, representing a valley fill, underlies most of PGDP and extends northward to the Ohio River. Figure 9.8 is a schematic cross section illustrating regional stratigraphic relationships in the vicinity of PGDP.

The local groundwater flow system at PGDP exists within the Cretaceous through Pleistocene sediments and Holocene alluvium. Four specific components have been identified as part of the groundwater flow system: the McNairy flow system, the regional gravel aquifer (RGA), the upper continental recharge system (UCRS), and the terrace gravels. The McNairy flow system, formerly termed the deep groundwater system, consists of interbedded and interlensing sand, silt, and clay of the McNairy Formation. Sand facies account for 40 to $50 \%$ of the total formation thickness of about $225 \mathrm{ft}$. The RGA consists of the Quaternary sand and gravel facies in the lower Continental Deposits and the Holocene alluvium adjacent to the Ohio River, both of which are of sufficient thickness and saturation to constitute an aquifer. These deposits have an average thickness of $30 \mathrm{ft}$ and range up to $50 \mathrm{ft}$ along an axis that trends east-west through the plant site. The RGA is the primary aquifer used locally by private residences north of PGDP. The UCRS consists mainly of clayey silt with interbedded sand and gravel in the upper Continental Deposits. Groundwater flow in the UCRS is predominantly downward, to recharge the RGA. The terrace gravels consist of shallow Pliocene gravel deposits in the southern portion of the plant site. 


\section{SOUTH}

\section{NORTH}

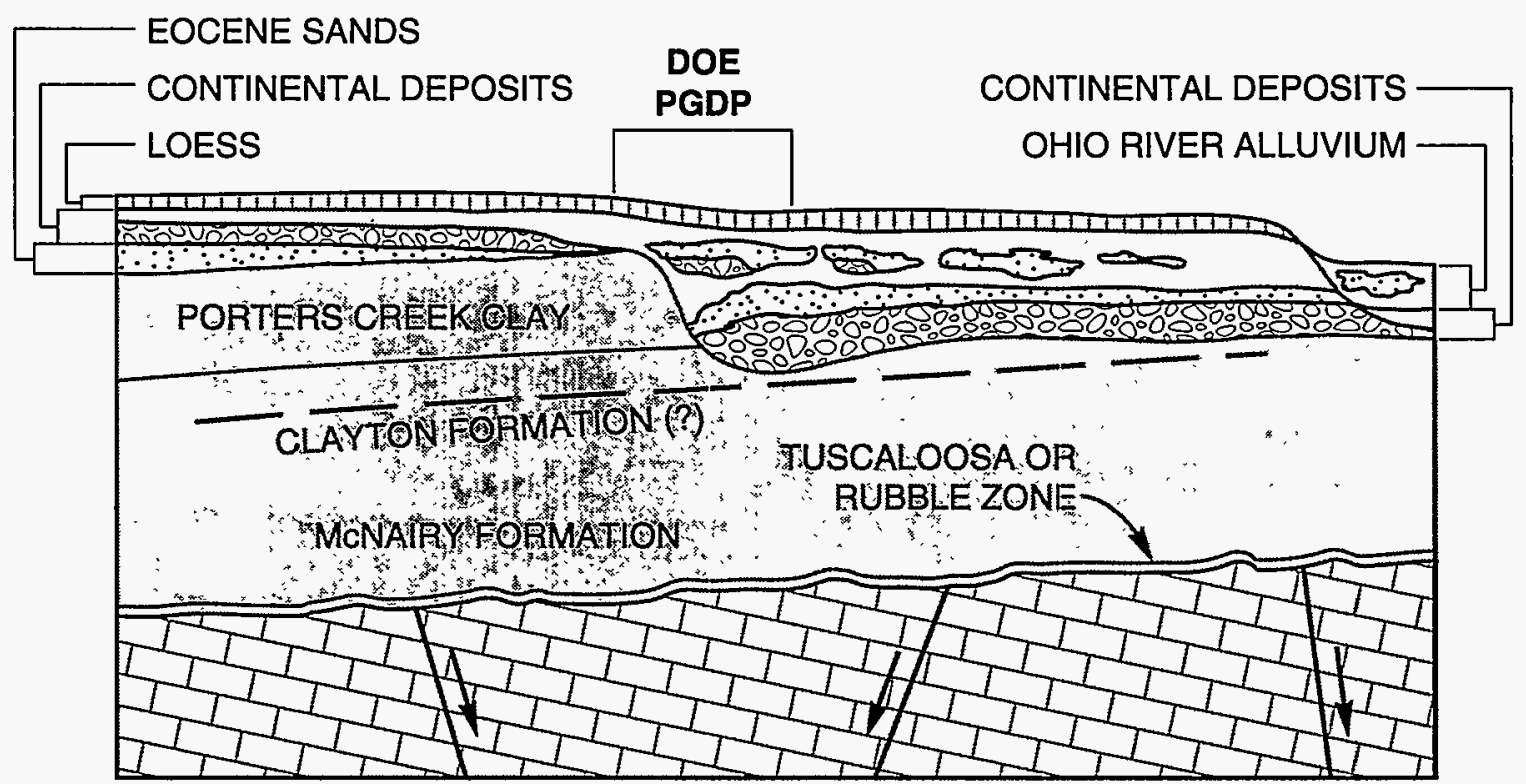

NOT TO SCALE

Fig. 9.8. Schematic of north-south section showing regional stratigraphic relationships at PGDP (from Phase III Groundwater Investigation).

These deposits usually lack sufficient thickness and saturation to constitute an aquifer but may be an important source of water to the lower Continental Deposits.

Topographically controlled recharge and discharge areas to the south and north, respectively, bound the local groundwater flow system. One area of recharge occurs south of PGDP within the area underlain by the Eocene sands and has resulted in a groundwater divide. Flow originates south of PGDP within the Eocene sands and the Pliocene terrace gravels. Groundwater within the Pliocene gravels either discharges to local streams or recharges the RGA. From the plant site, groundwater flows northward in the RGA toward the Ohio River, which is the local base level for the system.

\section{USES OF GROUNDWATER IN THE VICINITY}

PGDP is a major western Kentucky industry, employing about 1700 people from the four-state area (Kentucky, Illinois, Missouri, and Tennessee). The West Kentucky Wildlife Management Area and some lightly populated farmlands are in the immediate vicinity of PGDP. Homes are sparsely located along rural roads in the vicinity of the site. Three communities lie within 2 miles of the plant: Magruder Village to the southwest and Grahamville and Heath to the east.

Both groundwater and surface water sources are used for water supply to residents and industries in the PGDP area. Respondents to a surface water and groundwater user's survey conducted in 1990 numbered 872; of those respondents, $84 \%$ used well water as their sole water supply.

Wells in the area are screened in undefined lithologies at depths ranging from 15 to $245 \mathrm{ft}$; however, these wells are believed to be screened primarily in the RGA. PGDP has supplied water from a public water system to all groundwater users in the area affected by pollution from the plant. In October 1993, a water policy was initiated to supply all residents within the area of groundwater contamination with a municipal water supply by mid-1994.

\section{9-10 Groundwater}




\section{GROUNDWATER MONITORING PROGRAM}

The primary objectives of groundwater monitoring at PGDP are to detect as early as possible any contamination resulting from past and present land disposal of wastes and to provide the basis for developing groundwater quality assessments if contamination is detected. Additional objectives outlined in DOE Order 5400.1, General Environmental Protection Program, require that groundwater monitoring at all DOE facilities ". . . determine and document the effects of operations on groundwater quality and quantity." The order specifically requires groundwater monitoring to be conducted on-site and in the vicinity of DOE facilities to accomplish the following:

- obtain data to determine baseline conditions of groundwater quality and quantity;

- demonstrate compliance with, and implementation of, all applicable regulations and DOE orders;

- provide data to permit early detection of groundwater pollution or contamination;

- provide a reporting mechanism for detected groundwater pollution or contamination;

- identify existing and potential groundwater contamination sources and maintain surveillance of these sources; and

- provide data for making decisions about land disposal practices and the management and protection of groundwater resources.

These objectives are outlined in three PGDP documents relating to groundwater monitoring: Paducah Gaseous Diffusion Plant Groundwater Protection Program Management Plan (Miller and Douthitt 1993), Groundwater Monitoring Plan for the Paducah Gaseous Diffusion Plant, Paducah, Kentucky (Early, Sigmon, and Williams 1989), and Environmental Monitoring Plan (MMES 1992a).

The Groundwater Protection Program Management Plan formalizes and gives structure to the PGDP Groundwater Protection Program by identifying specific responsibilities and assigning them to various entities within the plant. Environmental Restoration and Environmental Management initiatives are coordinated within the plan to the greatest extent possible.

The Groundwater Monitoring Plan (1) targets the environmental protection of groundwater in a comprehensive blueprint for DOE to follow at each facility, (2) is consistent with DOE's commitment to operate its facilities in an environmentally safe manner, and (3) complies with all applicable and relevant environmental laws. The Groundwater Monitoring Plan fulfills these objectives for PGDP by providing a monitoring plan that accomplishes the following:

- develops an appropriate level of understanding of site geology and groundwater hydrology and of flow pathways and rates of contaminant migration from existing waste disposal sites to the underlying aquifer;

- provides the framework within which an integrated strategy for long-term monitoring of existing disposal sites can be developed to aid evaluation of remedial action alternatives; and

- creates a data base and fundamental geotechnical understanding of the site to facilitate future waste disposal decisions.

The Environmental Monitoring Plan contains the rationale and design criteria for site monitoring programs, the extent and frequency of monitoring and measurements, procedures for laboratory analyses, quality assurance requirements, program implementation procedures, and directions for the preparation and disposition of reports.

\section{Groundwater Monitoring}

Groundwater monitoring at PGDP is carried out by the Martin Marietta Energy Systems, Inc. (MMES), ERWM Groundwater Monitoring Section as specified in the Addendum to Sampling and Analysis Plan (Clausen 1992a). The addendum, updated annually as characterization continues, schedules sampling efforts for more than 
200 monitoring wells, residential wells, and Tennessee Valley Authority (TVA) wells. Well sampling is in accordance with several different monitoring programs, which are described as follows.

\section{Underground Siorage Tank (UST) Monitoring}

In 1989, petroleum hydrocarbons were discovered in a plant monitoring well northeast of the C-750 garage. Two underground fuel tanks at the garage were tested and found to be leaking. A site investigation confirmed the presence of soil and groundwater contamination near the garage, possibly caused by releases from the USTs. The two USTs were removed, and 13 monitoring wells, MW207-MW219, were installed in the UCRS. These wells and MW68 (RGA), MW69 (UCRS), MW71 (RGA), and MW96 (UCRS) served to monitor the two USTs at the C-750 garage and three additional USTs in the general vicinity. Results of a site investigation indicate that groundwater contamination from leaking USTs is limited to the UCRS, which is not considered to be an aquifer or a source of drinking water in the PGDP area.

\section{Resource Conservation and Recovery Act (RCRA) Interim Status and Permit Monitoring Programs}

Currently, the only RCRA facility at PGDP that requires groundwater monitoring is the C-404 low-level radioactive waste burial ground. This burial ground was operated until 1986, when hazardous material was discovered at the facility. The burial ground was covered with a RCRA clay cap and was certified closed as a hazardous waste landfill in 1987.

Sixteen wells, MW84-MW95, monitor groundwater quality of the UCRS and the underlying RGA during the required post-closure care period. In 1993, MW226 and MW227 were completed in the RGA upgradient of C-404. Groundwater monitoring results indicate that no release to the RGA has occurred.

\section{State Solid Waste Disposal Regulations}

Compliance monitoring requirements exist for facilities C-746-S and C-746-T, permitted by the KDWM. The C-746-T industrial landfill was closed in 1992 but is still waiting for certification of closure in accordance with state permit requirements. Cell 3 of the C-746-S landfill began receiving waste in July 1993.

Monitoring wells at the facilities are sampled quarterly. Sample analytes are dictated by the specific permit for each facility. UCRS wells MW16 and MW18; RGA wells MW17, MW19, MW38, MW39, MW41-MW44, and MW220-MW225; and McNairy well MW40 serve as monitoring stations for these facilities.

\section{CERCLA/ACO Monitoring (Off-Site Wells)}

The ACO between DOE and the EPA under CERCLA legislation requires monthly sampling of potentially affected off-site wells and plant well MW66 for TCE, ${ }^{99} \mathrm{Tc}$, and gross alpha and beta activity. During 1993, R294 was sampled weekly; R2, R5, R17, R18, R293, and R302 were sampled monthly; and R9, R12-R14, R19-R21, R23, R31, R39, R43, R72, R82-84, R90, and R381 were sampled semiannually.

Residents are given alternative water supplies if DOE-PGDP action levels of $1 \mu \mathrm{g} / \mathrm{L}$ TCE or $25 \mathrm{pCi} / \mathrm{L}{ }^{99} \mathrm{Tc}$ are exceeded. In October 1993, a water policy was initiated to supply all residents within the area of groundwater contamination with a municipal water supply. Supply connections will be complete by mid-1994.

\section{Environmental Surveillance Monitoring}

The Groundwater Surveillance Plan for the Paducah Gaseous Diffusion Plant (SAIC 1993b) describes monitoring of exit pathways along the northern boundary of the DOE reservation. Environmental surveillance also provides background information, allows sampling for DNAPLs, and can be used for special projects. The wells associated with environmental surveillance are

- $\quad$ MW98, MW99, MW106, MW121-MW128, MW132-MW139, MW146-MW150, MW154, MW158-MW184, MW188-MW195, MW197, MW198, MW200, and MW203-MW206 for exit pathways;

\section{9-12 Groundwater}


- MW102-MW104, MW120, MW129-MW131, MW140-MW143, MW151, MW196, and MW199 for background;

- MW155, MW157, and MW160 for DNAPL; and

- MW20, MW66, MW144, MW145, MW152, MW153, MW155-MW157, MW185-MW187, and MW200-MW202 for special projects.

\section{Hydrogeologic Services}

Hydrogeologic services at PGDP include three main responsibilities: oversight and maintenance of the PGDP Groundwater Protection Program as outlined in the Groundwater Protection Program Management Plan, technical oversight and input on environmental restoration projects, and technical services to line organizations as requested within the plant. The MMES ERWM Hydrogeologic Services Section has implemented or assisted in several activities designed to complement ongoing compliance and environmental restoration activities during 1993. These projects include a colloidal borescope investigation, a surfactant flush demonstration, ${ }^{99} \mathrm{Tc}$ colloid sampling, a hydraulic containment pilot study for the northwest plume, a borehole flowmeter study, startup of an on-site geotechnical lab, and oversight of field work for the RCRA facility investigation (RFI) for waste area groupings (WAGs) 1 and 7.

\section{Colloidal Borescope Investigation}

A downhole instrument, consisting of a camera, magnification lens, and a light source, measured groundwater flow rate and direction by direct observation as colloidal-size particles flowed across the camera's field of view. Flow directions measured by the borescope agree with those from potentiometric maps. The borescope identified zones within the aquifer where groundwater flow rate is unusually high. The colloidal borescope project also demonstrated that particles that are stationary in ambient groundwater flow velocities mobilize during sampling.

\section{INTERA Pilot Surfactant Flush Demonstration}

A consortium of groundwater researchers, headed by INTERA, Inc., began work at PGDP to demonstrate surfactant-aided DNAPL remediation. Surfactants are a class of chemicals that enhance the solubility of organic compounds. Where groundwater is contaminated with DNAPL, surfactants offer potential for enhancing the efficiency of pump-and-treat technology.

\section{${ }^{99}$ Te Colloid Sampling}

Oak Ridge National Laboratory helped in sampling three monitoring wells at PGDP to determine if ${ }^{99} \mathrm{Tc}$ is being cotransported with colloids or natural organic matter. Preliminary indications show that ${ }^{99} \mathrm{Tc}$ is not absorbing onto colloid particles. The final report is expected in early 1994.

\section{Hydraulic Containment Pilot Study of the Northwest Plume}

The EPA approved an Interim Action Record of Decision that is proposed as a first phase of remedial action for groundwater at PGDP and is not intended as a final action. The scope of this project is to install two extraction wells near the source and two additional extraction wells farther north near the plume's centroid or "hot spot." Each set of extraction wells will be surrounded by a monitoring well network. The monitoring well network, designed using a computerized optimization process, will be used for monitoring groundwater quality and water levels to determine the effectiveness of the interim action. The groundwater extraction system is intended to recover TCE- and technetium-contaminated groundwater from the RGA northwest of the PGDP boundary. Water extracted from the wells will be treated before being discharged into surface waters. 


\section{Borehole Flowmeter}

The TVA Engineering Laboratory was contracted to conduct electromagnetic borehole flowmeter testing in the RGA at PGDP. Flow distributions obtained during ambient conditions provide information on the direction of the vertical component of the hydraulic gradient. Flow distributions measured during pumping provide information on the relative differences of the horizontal hydraulic conductivity in the aquifer.

Measurements under ambient conditions indicated a small component of upward flow, although flow within the RGA is predominantly horizontal. Measurements while pumping two wells suggest that the upper portion of the aquifer may have a significantly higher hydraulic conductivity than lower portions. Such heterogeneity could be expected from a fluvial (braided stream) deposit.

\section{Geotechnical Lab}

The PGDP Environmental Restoration Program procured two sets of geotechnical testing equipment for soil samples taken at PGDP: (1) nests of sieves and a sieve shaker and (2) a triaxial cell permeameter. Sieve analysis of a soil sample yields the percentage distribution of soil particle size. The permeameter is used primarily to determine the hydraulic conductivity of an undisturbed soil sample. Both parameters are primary criteria for assessing contaminant transport.

No facility within the DOE complex of laboratories had previously existed to analyze geotechnical samples. Although an outside lab could be contracted to perform the analyses, these labs were generally unfamiliar with the environmental needs of PGDP. PGDP is now capable of analyzing certain geotechnical samples at low cost and with quick turnaround. These analyses, geared to specific needs at PGDP, allow for better interpretation of the hydrogeologic systems and ultimately more efficient remediation.

\section{RFI for WAGs 1 and 7}

The EPA and the commonwealth of Kentucky granted approval for the RFI Work Plan. Camp Dresser McKee Federal began field work in December 1993 and anticipates completion in summer 1994. The WAGs contain five underground storage tanks, a closed sanitary landfill, and three sites associated with former Kentucky Ordnance Works operations. The investigation will collect sufficient information to evaluate the riskbased extent of contamination and to collect data necessary for preparation of a corrective measures study.

\section{APPLICABLE MONITORING STANDARDS}

Table 9.1 lists the analysis parameters with regulatory limits or guidelines. This table also shows the wells that exceeded the reference value at least once during 1993.

\section{OPERABLE UNITS}

\section{WAGs}

At PGDP, solid waste management units (SWMUs) are surface sources of contamination. To expedite investigations, the SWMUs are grouped together by location into WAGs, as shown in Fig. 9.9. The WAGs are investigated as a RCRA facility in order to collect sufficient information on each SWMU to evaluate the extent of contamination and to collect data necessary for preparation of a corrective measures study. The sampling strategy collects only information as needed to make risk- and corrective action-based decisions. WAGs scheduled for action in the near future are listed in Table 9.2. RFI deliverables for FY 1995 and beyond are being negotiated under a federal facilities agreement. 
Table 9.1. Well monitoring at PGDP during 1993

\begin{tabular}{|c|c|c|c|}
\hline Parameter & $\begin{array}{l}\text { Applicable } \\
\text { value }\end{array}$ & Reference & $\begin{array}{l}\text { Wells exceeding reference } \\
\text { value at least once }\end{array}$ \\
\hline Aluminum & $0.05-0.2 \mathrm{mg} / \mathrm{L}$ & $a$ & $\begin{array}{l}\text { MW20, MW64-66, MW68, MW71, } \\
\text { MW96, MW98, MW99, MW102-104, } \\
\text { MW106, MW120-135, MW137-147, } \\
\text { MW149-152, MW154-166, MW168-175, } \\
\text { MW178-182, MW184-209, MW212-214, } \\
\text { MW216, MW218, MW219 }\end{array}$ \\
\hline Antimony & $0.006 \mathrm{mg} / \mathrm{L}$ & $b$ & MW151, MW197, MW198 \\
\hline Arsenic & $0.05 \mathrm{mg} / \mathrm{L}$ & $b$ & MW85, MW182, MW186 \\
\hline Barium & $2.0 \mathrm{mg} / \mathrm{L}$ & $b$ & None \\
\hline Beryllium & $0.004 \mathrm{mg} / \mathrm{L}$ & $b$ & MW20, MW98, MW121, MW181, MW185 \\
\hline Cadmium & $0.005 \mathrm{mg} / \mathrm{L}$ & $b$ & $\begin{array}{l}\text { MW18, MW85, MW91, MW96, MW121, } \\
\text { MW144, MW182, MW184, MW226 }\end{array}$ \\
\hline Chloride & $250 \mathrm{mg} / \mathrm{L}$ & $a$ & MW186, MW218 \\
\hline Chromium & $0.1 \mathrm{mg} / \mathrm{L}$ & $b$ & $\begin{array}{l}\text { MW63, MW64, MW66, MW71, MW89, } \\
\text { MW91, MW98, MW121, MW141, } \\
\text { MW144, MW 148-150, MW155, } \\
\text { MW160, MW168, MW175, MW178, } \\
\text { MW181, MW185, MW186, MW193, } \\
\text { MW195, MW197, MW199, MW200, } \\
\text { MW205, MW226 }\end{array}$ \\
\hline Color (of water) & 15 units & $a$ & MW18, MW20, MW223 \\
\hline Copper & $1.3 \mathrm{mg} / \mathrm{L}$ & $a$ & MW19 \\
\hline Fluoride & $4.0 \mathrm{mg} / \mathrm{L}$ & $b$ & MW178, MW182 \\
\hline Iron & $0.30 \mathrm{mg} / \mathrm{L}$ & $a$ & $\begin{array}{l}\text { MW16-21, MW38-42, MW44, MW46, } \\
\text { MW48, MW50-54, MW57, MW63, } \\
\text { MW64, MW66, MW68, MW69, MW71, } \\
\text { MW96, MW98, MW102-104, MW106, } \\
\text { MW120-130, MW133-135, MW137-152, } \\
\text { MW154-175, MW178-182, MW184-209, } \\
\text { MW212-217, MW219-225 }\end{array}$ \\
\hline Lead & $0.15 \mathrm{mg} / \mathrm{L}$ & $b$ & $\begin{array}{l}\text { MW17, MW42, MW43, MW69, MW86, } \\
\text { MW88, MW89, MW96, MW104, } \\
\text { MW196, MW199, MW219, MW227 }\end{array}$ \\
\hline Manganese & $0.05 \mathrm{mg} / \mathrm{L}$ & $a$ & $\begin{array}{l}\text { MW17, MW18, MW20, MW21, MW38, } \\
\text { MW40, MW46, MW48, MW50-54, } \\
\text { MW57, MW66, MW69, MW96, MW98, } \\
\text { MW102, MW104, MW106, MW120-129, } \\
\text { MW133, MW134, MW138, MW140, } \\
\text { MW141, MW143, MW146-148, MW150, } \\
\text { MW152, MW157-175, MW178-182, } \\
\text { MW184-187, MW189-197, MW199-203, } \\
\text { MW205, MW207, MW209, MW213, } \\
\text { MW216, MW217, MW219 }\end{array}$ \\
\hline Mercury & $0.002 \mathrm{mg} / \mathrm{L}$ & $b$ & None \\
\hline
\end{tabular}


Table 9.1 (continued)

\begin{tabular}{|c|c|c|c|}
\hline Parameter & $\begin{array}{l}\text { Applicable } \\
\text { value }\end{array}$ & Reference & $\begin{array}{l}\text { Wells exceeding reference } \\
\text { value at least once }\end{array}$ \\
\hline Nickel & $0.1 \mathrm{mg} / \mathrm{L}$ & $b$ & $\begin{array}{l}\text { MW66, MW163, MW181-182, MW185, } \\
\text { MW187, MW192, MW193, MW201, } \\
\text { MW223 }\end{array}$ \\
\hline Nitrate as nitrogen & $10 \mathrm{mg} / \mathrm{L}$ & $b$ & MW175 \\
\hline $\mathrm{pH}$ & $\begin{array}{l}6.5-8.5 \text { standard } \\
\text { units }\end{array}$ & $a$ & $\begin{array}{l}\text { MW16-21, MW38-44, MW47, MW48, } \\
\text { MW51-54, MW63-69, MW71, } \\
\text { MW84-96, MW98, MW99, MW102-104, } \\
\text { MW106, MW107, MW114, MW115, } \\
\text { MW121-130, MW132-135, MW137, } \\
\text { MW139-152, MW154-175, MW178, } \\
\text { MW179, MW181, MW182, MW184-197, } \\
\text { MW199-209, MW212-217, MW219-227, } \\
\text { R6, R8-10, R12-14, R19, R21-26, R28, } \\
\text { R39-42, R53, R54, R66, R69, R72, R79, } \\
\text { R82-84, R88-90, R112, R117, R253, } \\
\text { R254, R278, R293, R294, R302, R368, } \\
\text { R381, R386, R424, R432, R509, R512 }\end{array}$ \\
\hline Selenium & $0.05 \mathrm{mg} / \mathrm{L}$ & $b$ & MW53 \\
\hline Sulfate & $250 \mathrm{mg} / \mathrm{L}$ & $a$ & MW21, MW47 \\
\hline Thallium & $0.002 \mathrm{mg} / \mathrm{L}$ & $b$ & MW121, MW175 \\
\hline Total dissolved solids & $500 \mathrm{mg} / \mathrm{L}$ & $a$ & $\begin{array}{l}\text { MW17, MW18, MW21, MW42, MW47, } \\
\text { MW127, MW149, MW174, MW179, } \\
\text { MW180, MW182, MW184, MW186, } \\
\text { MW187, MW190, MW198, MW207, } \\
\text { MW209, MW216, MW218-220 }\end{array}$ \\
\hline Water turbidity & $\begin{array}{l}5 \text { nephelometric } \\
\text { turbidity units }\end{array}$ & $b$ & $\begin{array}{l}\text { MW17-20, MW38, MW39, MW41-44, } \\
\text { MW46-48, MW52, MW54, MW57, } \\
\text { MW63, MW64, MW66, MW68, MW69, } \\
\text { MW96, MW98, MW99, MW102-104, } \\
\text { MW106, MW120-123, MW125, } \\
\text { MW128-130, MW133-135, MW137-142, } \\
\text { MW144-148, MW150, MW152, } \\
\text { MW154-164, MW166-175, MW178-182, } \\
\text { MW184-208, MW212-215, MW219-225 }\end{array}$ \\
\hline Zinc & $5.0 \mathrm{mg} / \mathrm{L}$ & $a$ & None \\
\hline Benzene & $0.005 \mathrm{mg} / \mathrm{L}$ & $b$ & None \\
\hline Carbon tetrachloride & $0.005 \mathrm{mg} / \mathrm{L}$ & $b$ & None \\
\hline 1,2-Dichloroethane & $0.005 \mathrm{mg} / \mathrm{L}$ & $b$ & None \\
\hline Cis-1,2-dichloroethene & $0.07 \mathrm{mg} / \mathrm{L}$ & $b$ & MW185, MW186 \\
\hline Trans-1,2-dichloroethene & $0.1 \mathrm{mg} / \mathrm{L}$ & $b$ & None \\
\hline 1,1-Dichloroethene & $0.007 \mathrm{mg} / \mathrm{L}$ & $b$ & None \\
\hline Ethyl benzene & $0.7 \mathrm{mg} / \mathrm{L}$ & $b$ & MW70, MW96 \\
\hline Polychlorinated biphenyls & $0.0005 \mathrm{mg} / \mathrm{L}$ & $b$ & None \\
\hline Tetrachloroethene & $0.005 \mathrm{mg} / \mathrm{L}$ & $b$ & MW155 \\
\hline Toluene & $1 \mathrm{mg} / \mathrm{L}$ & $b$ & None \\
\hline
\end{tabular}


Table 9.1 (continued)

\begin{tabular}{|c|c|c|c|}
\hline Parameter & $\begin{array}{l}\text { Applicable } \\
\text { value }\end{array}$ & Reference & $\begin{array}{l}\text { Wells exceeding reference } \\
\text { value at least once }\end{array}$ \\
\hline 1,1,2-Trichloroethane & $0.005 \mathrm{mg} / \mathrm{L}$ & $b$ & None \\
\hline Trichloroethylene & $0.005 \mathrm{mg} / \mathrm{L}$ & $b$ & $\begin{array}{l}\text { MW20, MW22, MW39, MW41, MW44, } \\
\text { MW47, MW63-66, MW68, MW69, } \\
\text { MW71, MW88, MW91, MW94, MW96, } \\
\text { MW108, MW124, MW126, MW134, } \\
\text { MW144, MW145, MW147, MW148, } \\
\text { MW152, MW154-164, MW168, MW172, } \\
\text { MW175, MW178, MW185-188, MW193, } \\
\text { MW197, MW201-204, MW209, MW213, } \\
\text { MW215-219, MW224, MW226, R2, R82, } \\
\text { R113, R424, R432 }\end{array}$ \\
\hline Vinyl chloride & $0.002 \mathrm{mg} / \mathrm{L}$ & $b$ & MW186 \\
\hline Xylene & $10 \mathrm{mg} / \mathrm{L}$ & $b$ & None \\
\hline Neptunium-237 & $1.2 \mathrm{pCi} / \mathrm{L}$ & $c$ & None \\
\hline Plutonium-239 & $1.2 \mathrm{pCi} / \mathrm{L}$ & $c$ & None \\
\hline Radon-222 & $300 \mathrm{pCi} / \mathrm{L}$ & $d$ & $\begin{array}{l}\text { MW103, MW129-131, MW142, MW143, } \\
\text { MW151, MW196, MW199, R10, R12-14, } \\
\text { R19, R29, R39, R40, R54, R68, R294, } \\
\text { R393, R512 }\end{array}$ \\
\hline Radium-226 & $20 \mathrm{pCi} / \mathrm{L}$ & $d$ & None \\
\hline Technetium-99 & $4 \mathrm{mrem} / \mathrm{year}$ & $d$ & None \\
\hline Thorium-230 & $12 \mathrm{pCi} / \mathrm{L}$ & $c$ & None \\
\hline Uranium & $\begin{array}{l}30 \mathrm{pCi} / \mathrm{L} \\
\quad \text { (or } 0.02 \mathrm{mg} / \mathrm{L} \text { ) }\end{array}$ & $d$ & MW182, MW216 \\
\hline Gross alpha & $15 \mathrm{pCi} / \mathrm{L}$ & $b$ & $\begin{array}{l}\text { MW17, MW66, MW96, MW120-122, } \\
\text { MW139, MW154, MW160, MW168, } \\
\text { MW172, MW175, MW178, MW180-182, } \\
\text { MW185, MW186, MW190, MW193, } \\
\text { MW204, MW207, MW213, MW216, R2 }\end{array}$ \\
\hline Gross beta & $4 \mathrm{mrem} / \mathrm{year}$ & $d$ & None \\
\hline
\end{tabular}

${ }^{a} 40$ CFR Pt. 143. National Secondary Drinking Water Regulations, as amended.

${ }^{b} 40$ CFR Pt. 141. Safe Drinking Water Act-National Primary Drinking Water Regulations, as amended.

Four percent of derived concentration guidelines for air and water (4 mrem/year), DOE Order 5400.5, Radiation Protection of the Public and the Environment.

${ }^{d}$ Proposed maximum contaminant level in 56 Federal Register, July 18, 1991, National Primary Drinking Water Regulations for Radionuclides in Drinking Water.

\section{Groundwater In'́egrator Unir}

Investigations have led to the discovery of three separate groundwater plumes (see Fig. 9.10), the primary contaminants of which are TCE and ${ }^{99} \mathrm{Tc}$. The contaminated groundwater is grouped within a groundwater integrator unit for investigation and remediation. Groundwater is grouped this way because (1) the contamination is isolated from surface sources, (2) sources of contamination are uncertain, (3) the groundwater underlies many 


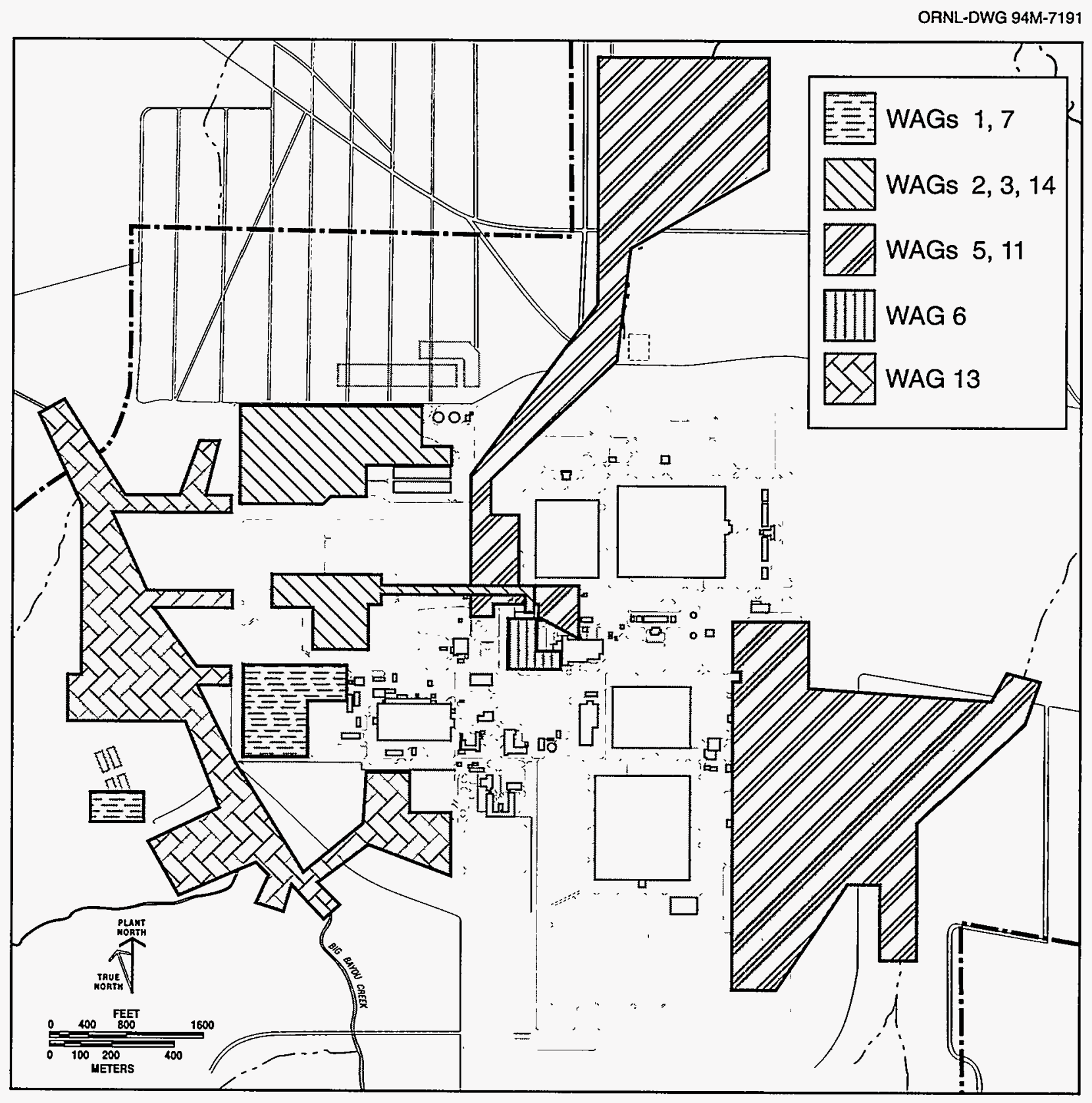

Fig. 9.9. PGDP WAGs.

WAGs, and (4) the groundwater will be remediated independent of other SWMUs (in part because of the presence of.DNAPLs).

An Interim Action Record of Decision for the northwest plume was agreed on in 1993 by the EPA, the commonwealth of Kentucky, and DOE. The decision is proposed as a first phase of remedial action for groundwater at PGDP and is not intended as a final action. For details on the scope of this project, see the earlier description of the hydraulic containment pilot study of the northwest plume under "Hydrogeologic Services."

An interim corrective measures work plan for the northeast plume was submitted to the EPA and the commonwealth of Kentucky in November 1993 and was approved in early 1994. An investigation into the extent and sources of contamination of the plume has been planned and will begin in March 1994. 
Table 9.2. PGDP WAGs scheduled for action in the near future

\begin{tabular}{|c|c|c|}
\hline WAGs & Solid waste management unit description & Status \\
\hline 1,7 & $\begin{array}{l}\text { C-746-K inactive sanitary landfill } \\
\text { C-615 sewage treatment plant } \\
\text { KOW trickling filter and leach field } \\
\text { KOW burn area } \\
\text { Fire training area } \\
\text { C-740 trichloroethylene spill site } \\
\text { C-611 55-gal gasoline UST } \\
\text { C-611 50-gal gasoline UST } \\
\text { C-611 2000-gal oil UST } \\
\text { C-611 unknown size, grouted UST } \\
\text { C-611 1000-gal diesel/gasoline tank } \\
\text { KOW toluene spill area }\end{array}$ & $\begin{array}{l}\text { A draft RFI work plan was submitted to the } \\
\text { commonwealth of Kentucky and the } \\
\text { EPA in September 1992. Field work is } \\
\text { under way }\end{array}$ \\
\hline 5,11 & $\begin{array}{l}\text { C-746-D classified scrap yard } \\
\text { C-633 polychlorinated biphenyl spill site } \\
\text { C-632-B sulfuric acid storage tank } \\
\text { C-531 electric switchyard } \\
\text { C-533 electric switchyard } \\
\text { C- } 633 \text { pumphouse and cooling tower } \\
\text { C-745 Kellogg building site } \\
\text { C-340 hydraulic system } \\
\text { C-410-B hydrogen fluoride neutralization } \\
\text { lagoon } \\
\text { C-410-C neutralization tank } \\
\text { C-405 incinerator } \\
\text { C-635 pumphouse and cooling tower } \\
\text { Residential/inert landfill borrow area }\end{array}$ & $\begin{array}{l}\text { A draft RFI work plan was submitted to the } \\
\text { commonwealth of Kentucky and the } \\
\text { EPA in June } 1992\end{array}$ \\
\hline $\begin{array}{c}2,3 \\
14\end{array}$ & $\begin{array}{l}\text { C-747 contaminated burial ground } \\
\text { C-746-F classified burial ground } \\
\text { C-747-B burial area } \\
\text { C-746-P clean scrap yard } \\
\text { C- } 400 \text { to C-404 underground transfer line }\end{array}$ & $\begin{array}{l}\text { A draft work plan was submitted to the } \\
\text { commonwealth of Kentucky and the } \\
\text { EPA in April } 1993\end{array}$ \\
\hline 13 & $\begin{array}{l}\text { C-611-W sludge lagoon } \\
\text { C-611-Y overflow lagoon } \\
\text { C- } 611-\mathrm{V} \text { lagoon } \\
\text { C-100 south side berm }\end{array}$ & $\begin{array}{l}\text { A draft work plan was submitted to the } \\
\text { commonwealth of Kentucky and the } \\
\text { EPA in July } 1993\end{array}$ \\
\hline 6 & $\begin{array}{l}\text { C-400 trichloroethylene leak site } \\
\text { C-400 technetium storage tank area } \\
\text { C- } 420 \text { polychlorinated biphenyl spill site } \\
\text { C-400 basement sump } \\
\text { C-403 neutralization tank } \\
\text { UF }_{6} \text { cylinder drop test area }\end{array}$ & $\begin{array}{l}\text { A draft RFI work plan is scheduled to be } \\
\text { submitted to the commonwealth of } \\
\text { Kentucky and the EPA in July } 1994\end{array}$ \\
\hline
\end{tabular}




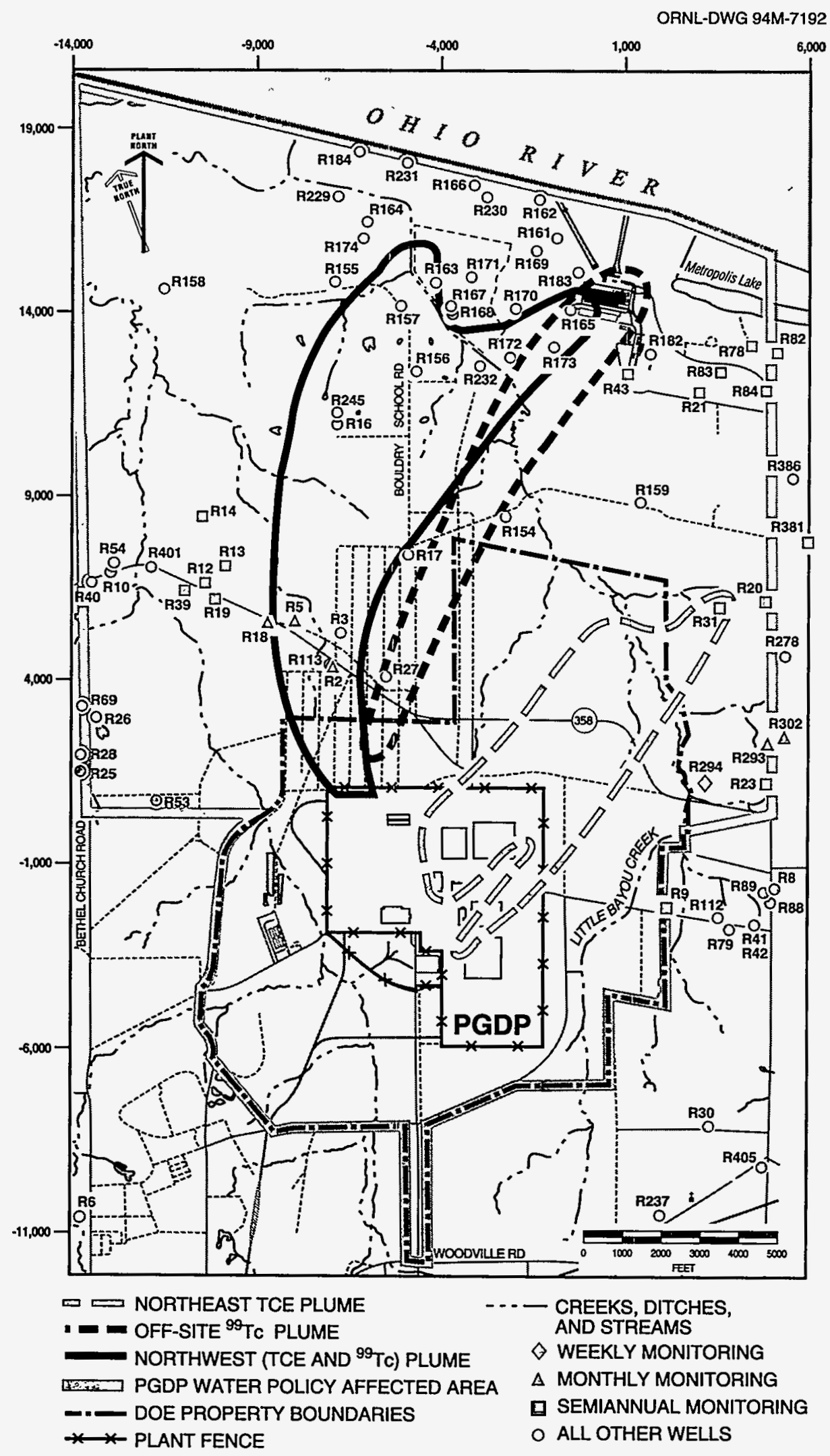

Fig. 9.10. Groundwater plume and water policy map. 


\section{GROUNDWATER MONITORING RESULTS}

Groundwater monitoring results from all sampling efforts conducted by MMES are compiled in the ERWM computer data base (EIMS-Environmental Information Management System). A complete listing of analytical results is available upon request from the PGDP ERWM Public Affairs Department. This section incorporates historical data stored on EIMS from 1991 through 1993 into graphs of detectable quantities of TCE and ${ }^{99} \mathrm{Tc}$ for wells mentioned in the monitoring programs (see "Groundwater Monitoring Program").

\section{UST Results}

MW96, closer to the UST area than the other UST wells showing benzene, toluene, ethyl benzene, and xylene concentrations, appears to be decreasing in both ethyl benzene and xylene concentrations. MW69, farther from the UST area, retains relatively stable concentrations of ethyl benzene and xylene below drinking water standards (see Figs. 9.11 and 9.12). Except for anomalous values, no other benzene, toluene, ethyl benzene, or xylene was detected.

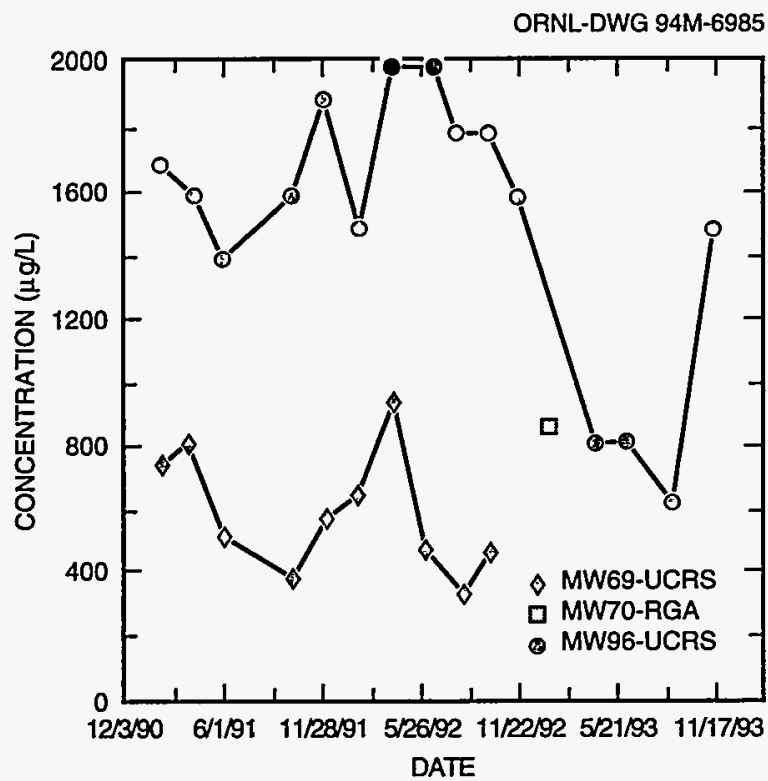

Fig. 9.11. UST results for ethyl benzene.

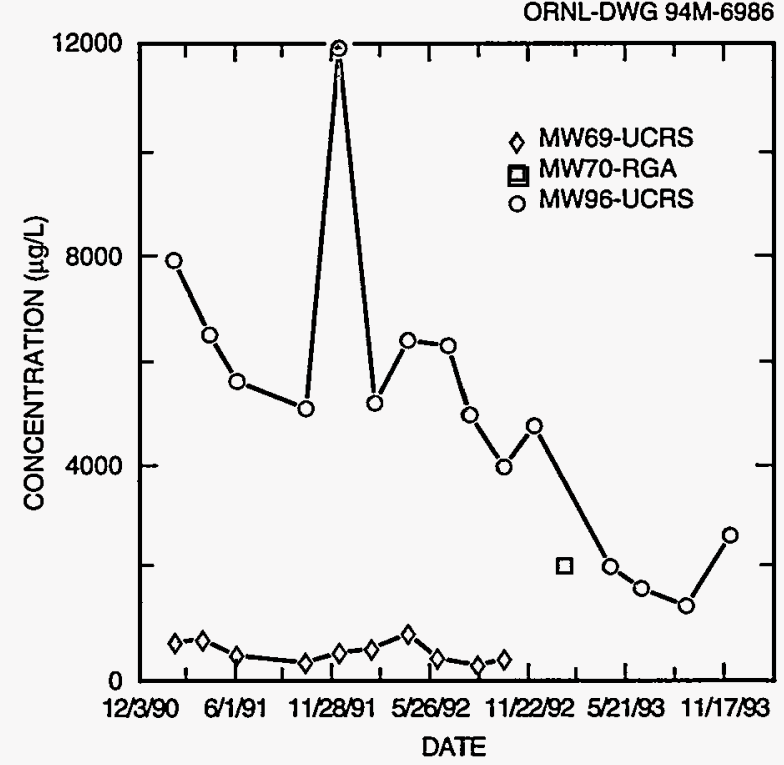

Fig. 9.12. UST results for xylene.

\section{RCRA C-404 Results}

MW88, in the UCRS, appears to show an increase in TCE levels since 1991. The well is downgradient of the closed C-404 landfill. However, because MW88 is screened in the shallow sediments above the aquifer and regional gravel aquifer wells in the area indicate either nondetectable or anomalous values of TCE, MW88 is not currently a major concern. All C-404 wells, with the exception of MW84 and one anomalous value, contained ${ }^{99} \mathrm{Tc}$ activities below or near the level quantifiable by the lab $(25 \mathrm{pCi} / \mathrm{L})$. (See Figs. 9.13 through 9.16.$)$ 
ORNL-DWG 94M-6987

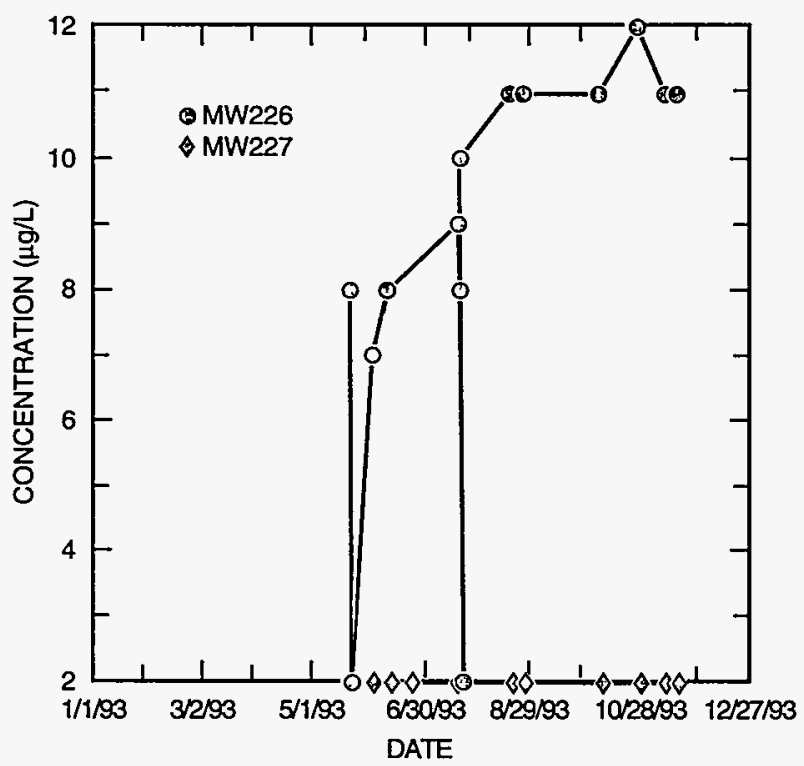

Fig. 9.13. Background C-404 TCE results for the RGA.
ORNL-DWG 94M-6989

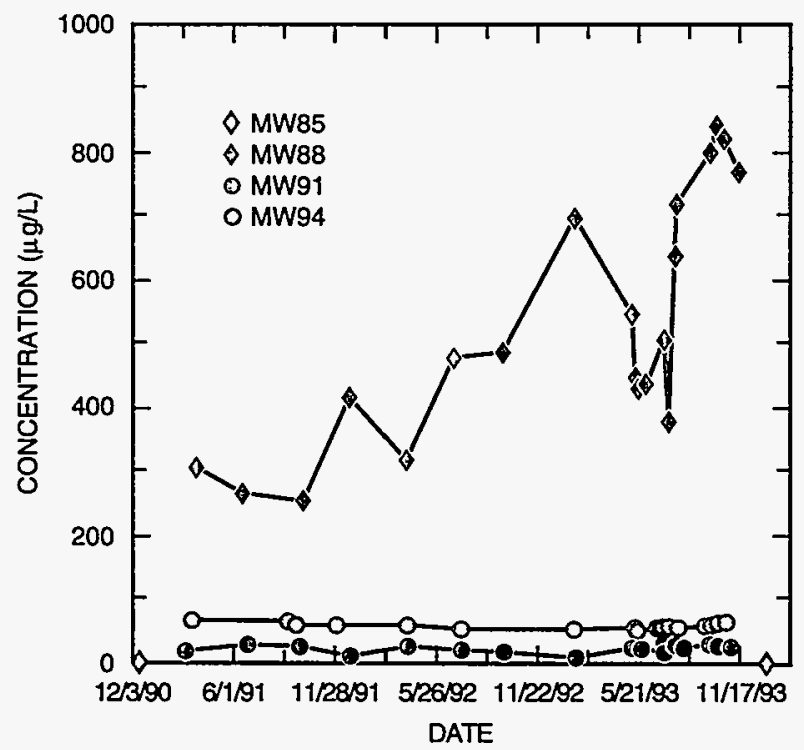

Fig. 9.15. C-404 TCE results for the UCRS.

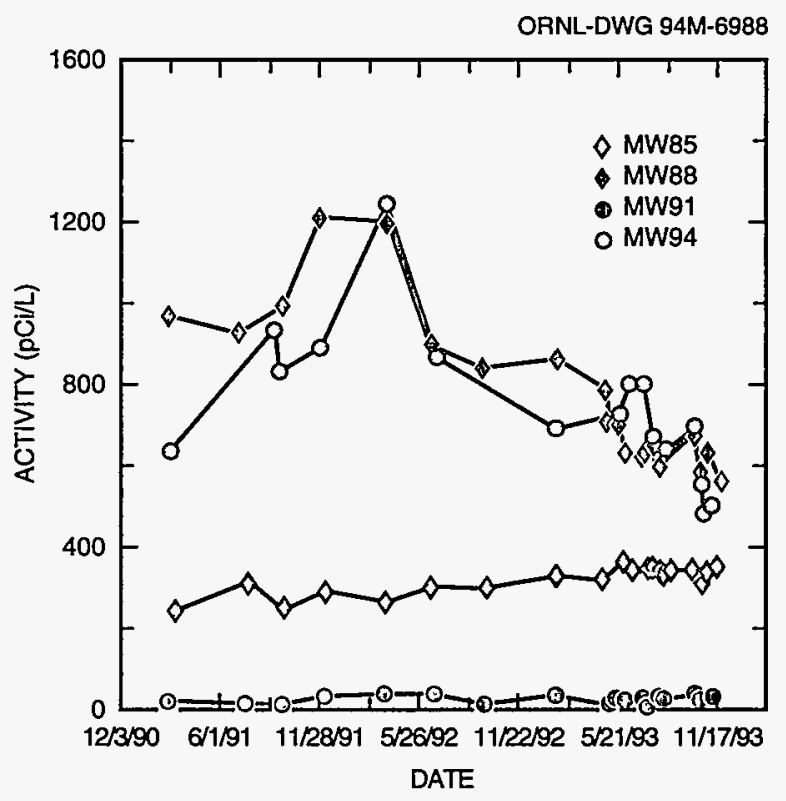

Fig. 9.14. C-404 ${ }^{99} \mathrm{TC}$ results for the UCRS.

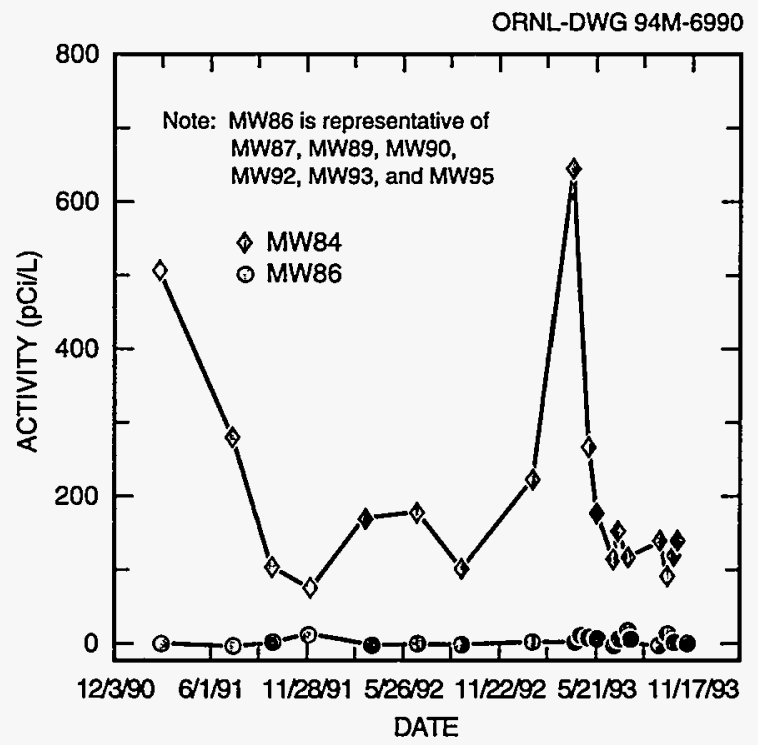

Fig. 9.16. C-404 ${ }^{99} \mathrm{TC}$ results for the RGA. The plot of MW86 is representative of MW87, MW89, MW90, MW92, MW93, and MW95. MW95's value of $847 \mathrm{pCi} / \mathrm{L}$ on October 5,1992 , was left out to clarity the graph. 


\section{C-746-S and C-746-T Landfill Results}

Two wells, MW41 and MW44, yield water with TCE levels above drinking water standards. Over time, concentrations of TCE vary in both wells about a consistent mean value. These two wells were constructed in 1982 and do not meet current construction standards. The isolated occurrences of TCE seem to indicate failure of the well seals. A new groundwater monitoring plan has been submitted to the KDWM that includes installation of new wells and abandonment of the older wells. Technetium-99 activities at the C-746-S and C-746-T landfills were below or near quantifiable levels. (See Figs. 9.17 through 9.24.)

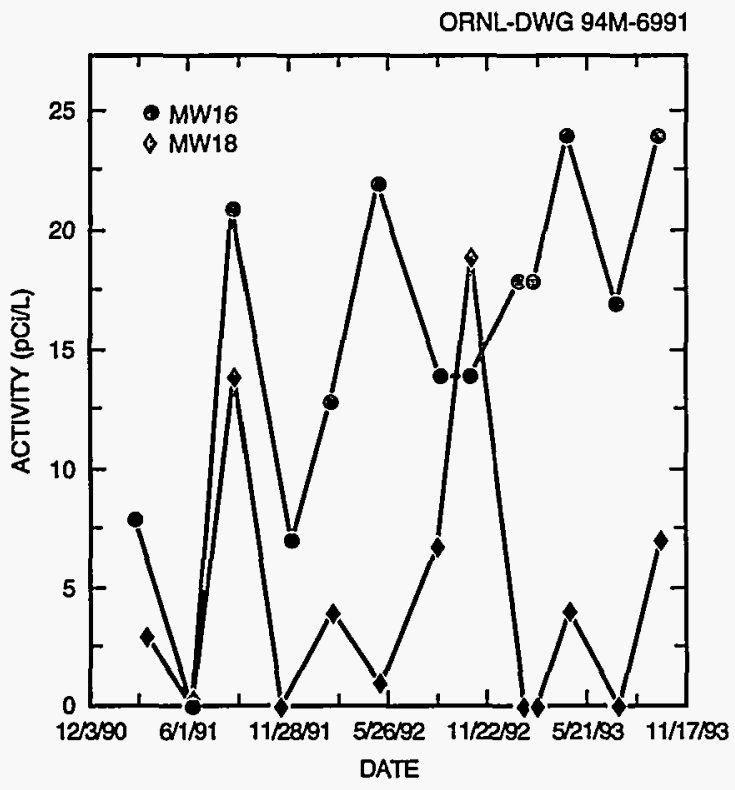

Fig. 9.17. C-746-S and C-746-T, ${ }^{99} \mathrm{TC}$ monitoring of the UCRS.

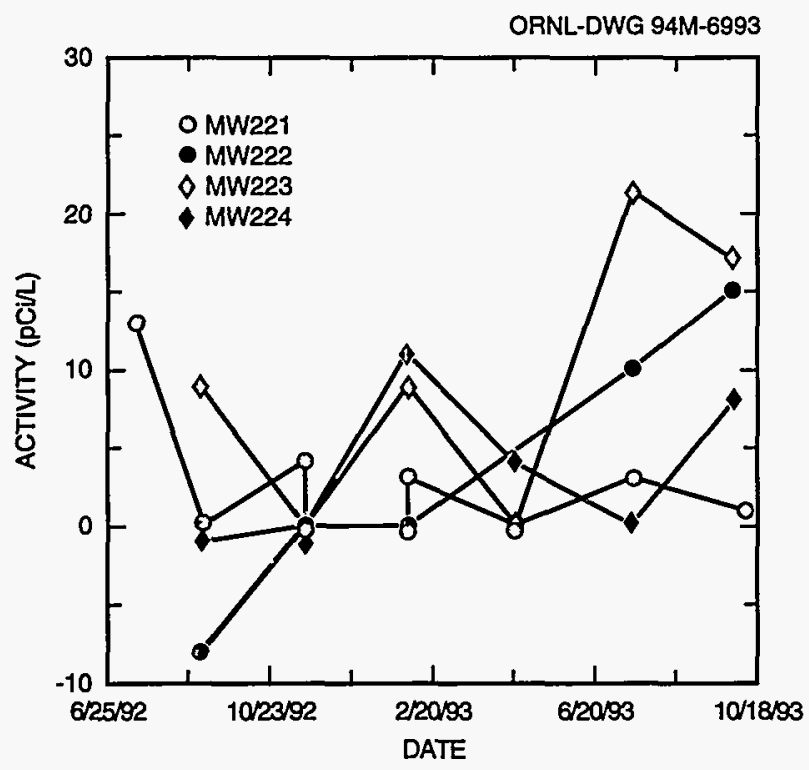

Fig. 9.19. C-746-S and C-746-T ${ }^{99} \mathrm{TC}$ results for the RGA (plot 2). Every other data point before 1993 was omitted to clarify the graph.

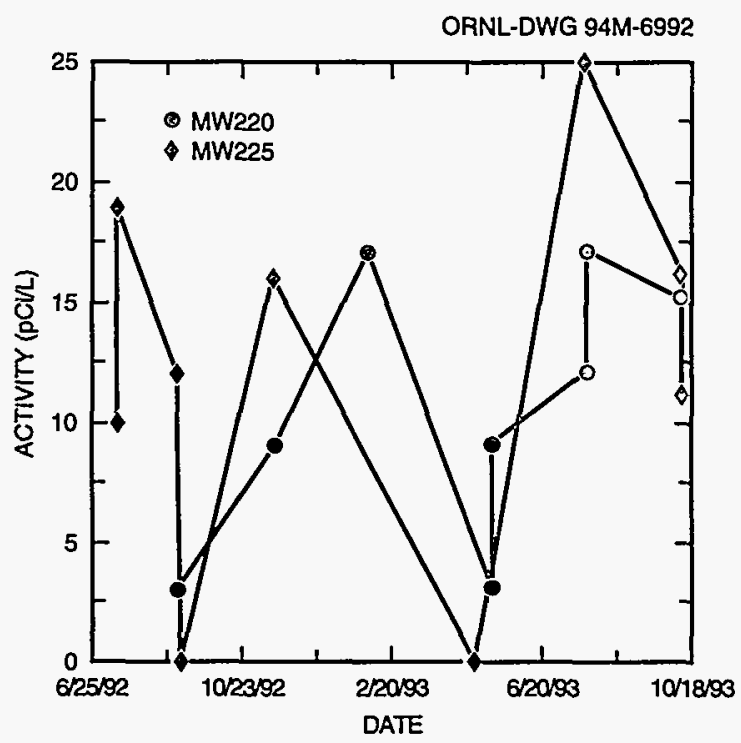

Fig. 9.18. Background C-746-S and C-746-T ${ }^{99}$ TC results for the RGA (plot 1).

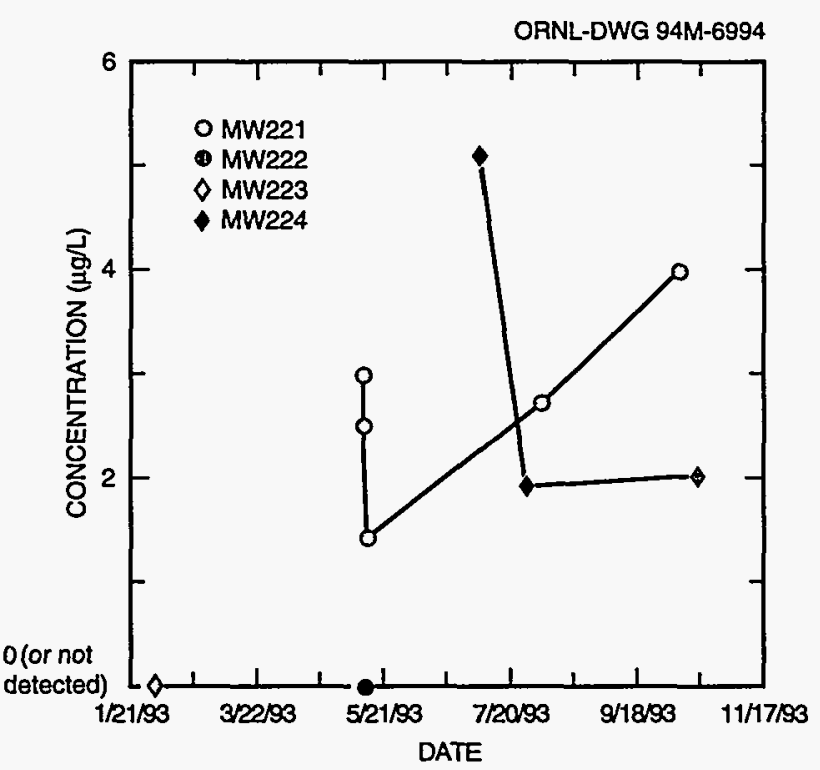

Fig. 9.20. C-746-S and C-746-T TCE results for the RGA (plot 2). Every other data point before 1993 was omitted to clarify the graph. 


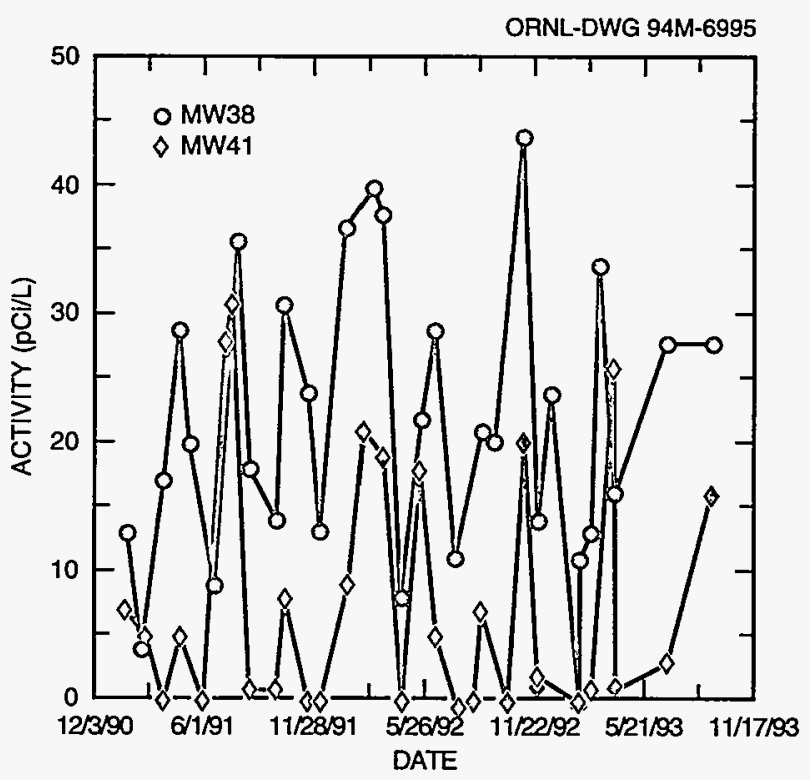

Fig. 9.21. C-746-S and C-746-T ${ }^{99} \mathrm{Tc}$ results for the RGA (plot 3). Every other data point before 1993 was omitted to clarify the graph.

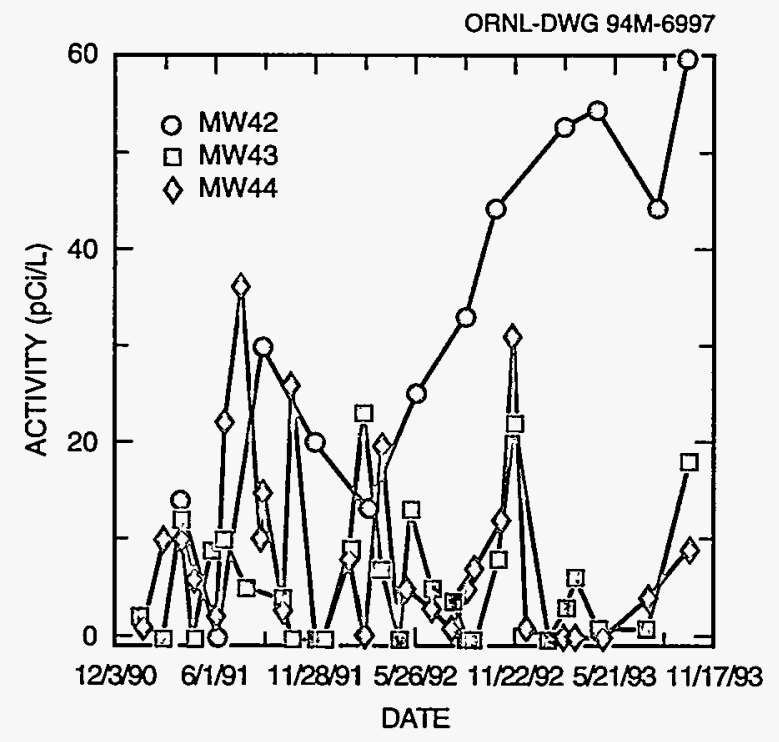

Fig. 9.23. C-746-S and C-746-T ${ }^{99} \mathrm{TC}$ results for the RGA (plot 4). Every other data point before 1993 was omitted to clarify the graph.

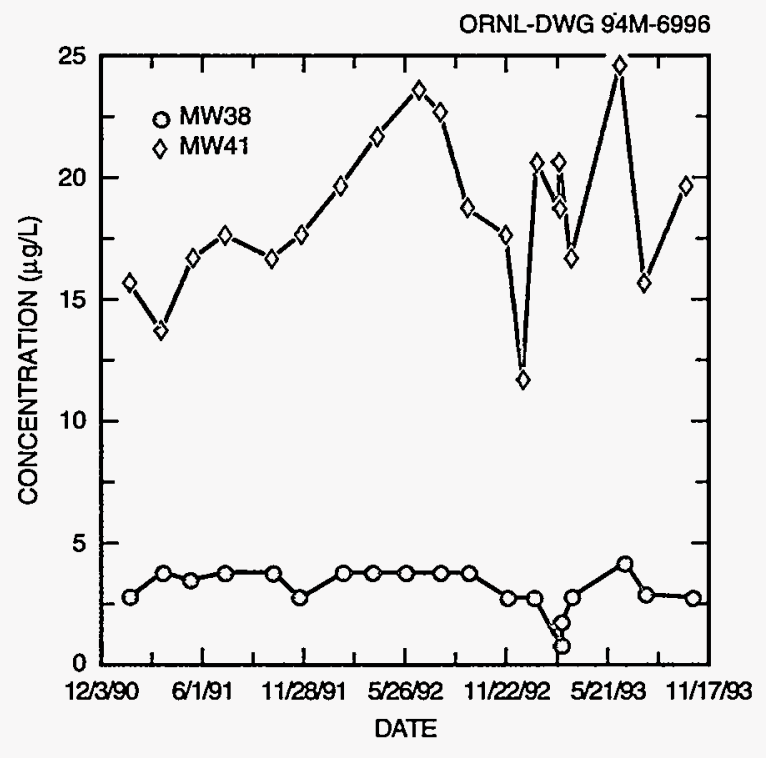

Fig. 9.22. C-746-S and C-746-T TCE results for the RGA (plot 3). Every other data point before 1993 was omitted to clarify the graph.

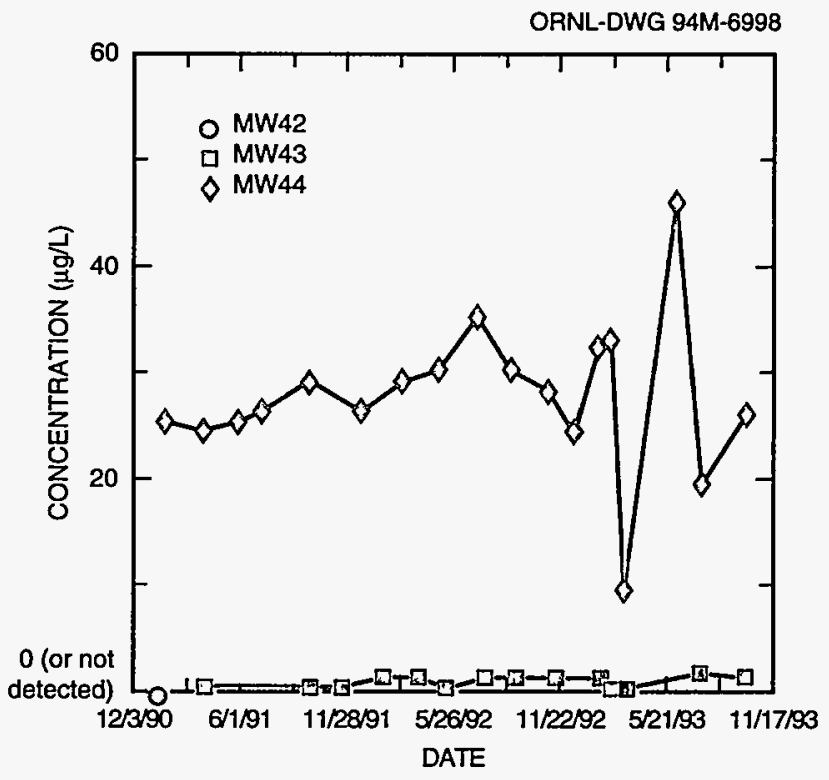

Fig. 9.24. C-746-S and C-746-T TCE results for the RGA (plot 4). Every other data point before 1993 was omitted to clarify the graph. One value of TCE, $120 \mu \mathrm{g} / \mathrm{L}$ on December 6, 1991, was omitted to clarify the graph. 


\section{ACO Results}

The two wells that showed detectable TCE and ${ }^{99} \mathrm{Tc}$ are located near the center of the northwest plume. The widely fluctuating nature of $R 2$ values in comparison with the $R 17$ values is probably a function of distance to source. All other values for TCE and ${ }^{99} \mathrm{Tc}$ in the ACO wells were below quantifiable limits or not detected (see Figs. 9.25 and 9.26).

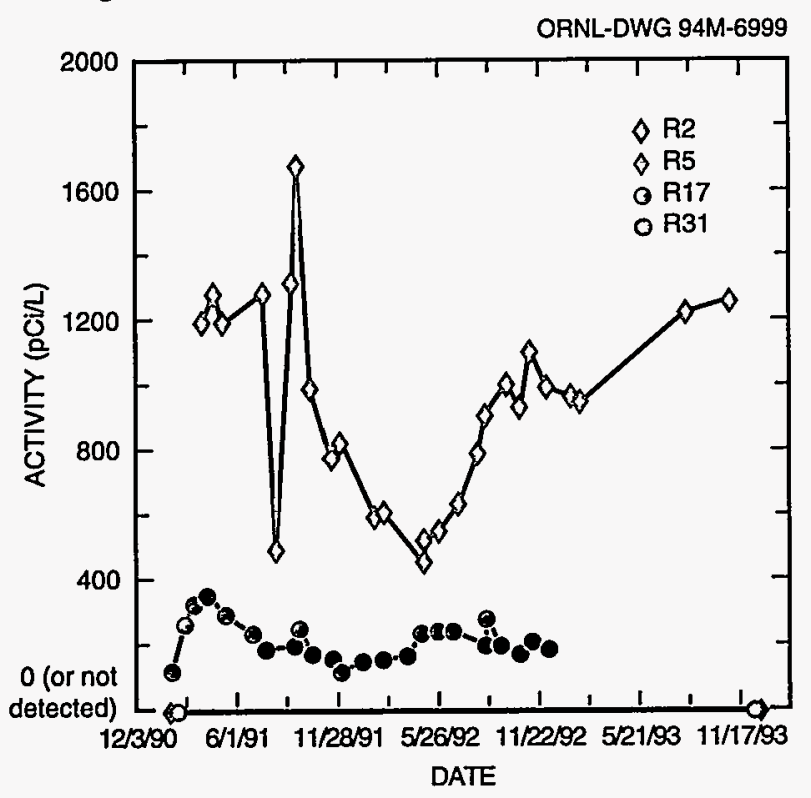

Fig. 9.25. ACO results for ${ }^{99} \mathrm{Tc}$ monitoring. (Wells are believed to be installed in the RGA.)

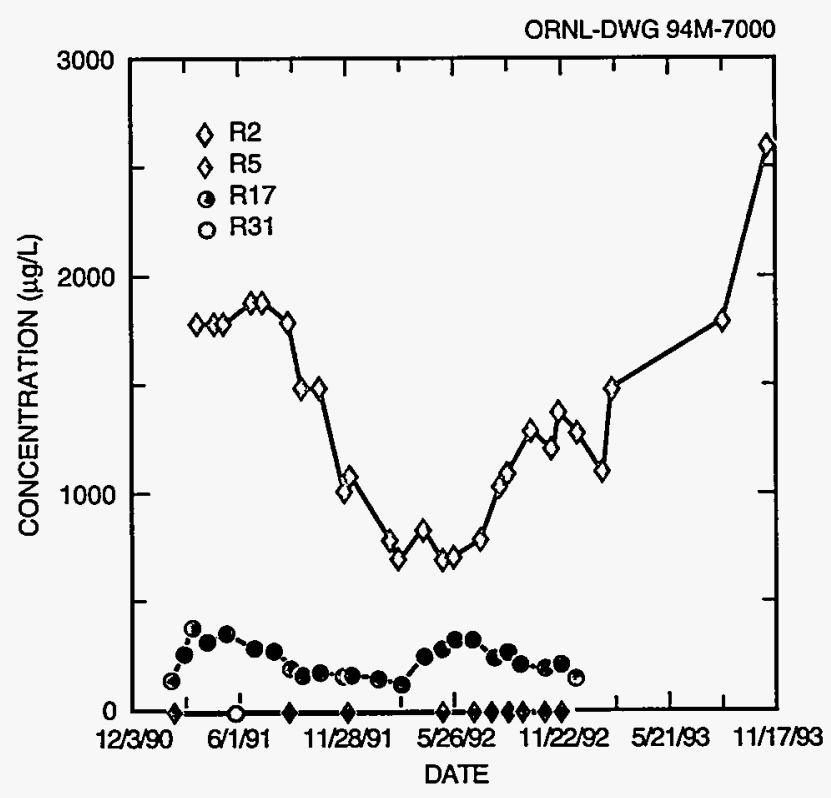

Fig. 9.26. ACO results for TCE monitoring. (Wells are believed to be installed in the RGA.)

\section{Background Monitoring Results}

All values for TCE and ${ }^{99} \mathrm{Tc}$ in the background monitoring wells were below quantifiable limits or were not detected (see Figs. 9.27 and 9.28).

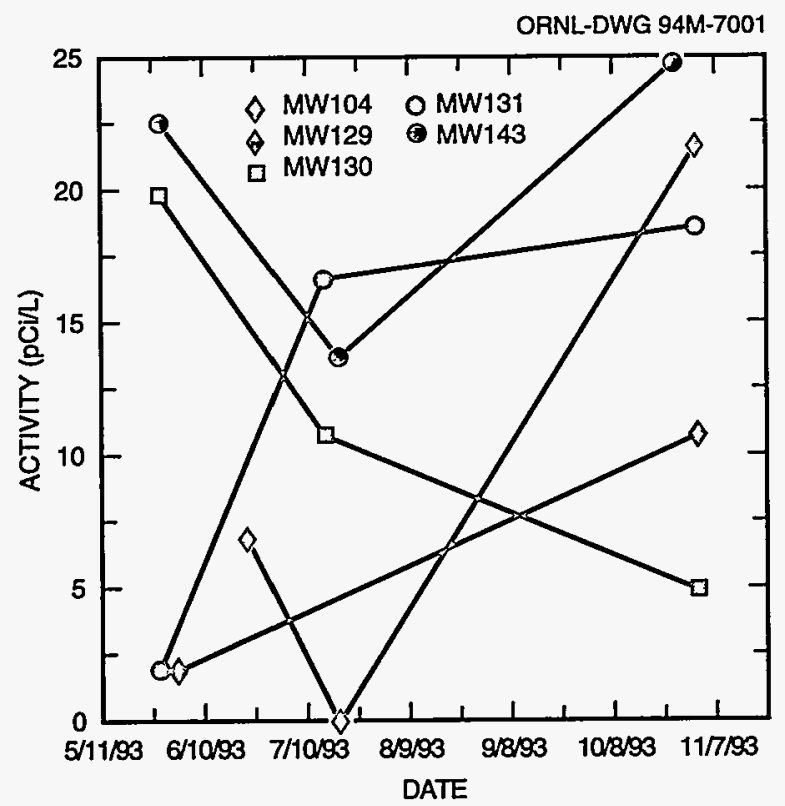

Fig. 9.27. Background monitoring results for ${ }^{99} \mathrm{TC}$ in the UCRS.

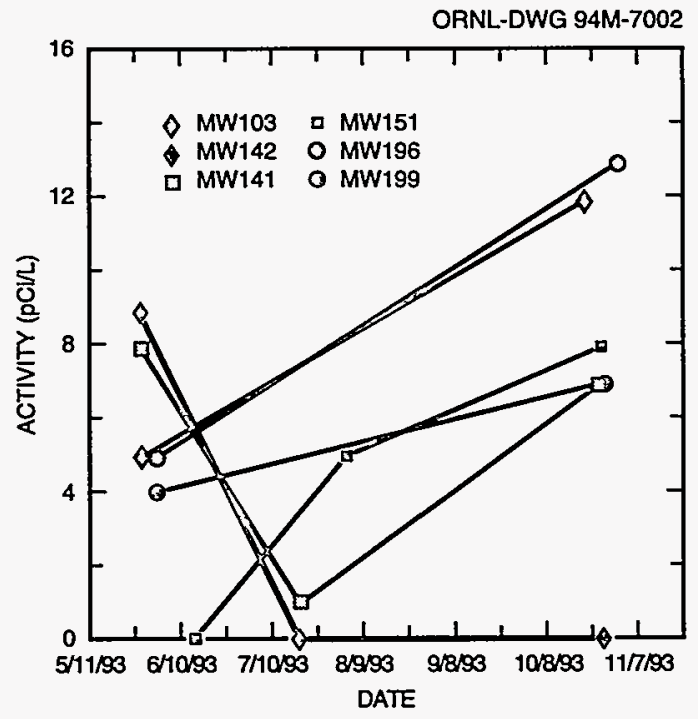

Fig. 9.28. Background monitoring results for ${ }^{99} \mathrm{Tc}$ in the RGA. Two values, $2 \mathrm{pCi} / \mathrm{L}$ on March 5 , 1992, for MW103 and 6.3 pCi/L on August 11, 1992, for MW196, were omitted to clarify the graph.

Groundwater 


\section{DNAPL Results}

TCE DNAPL wells show no indication of increases or decreases in TCE concentration. The highest TCE concentration occurs in the UCRS and upper RGA at C-400. Without some method of removal or containment, the DNAPL will continue to function as a source to a dissolved-phase TCE plume. (See Fig. 9.29.)

\section{Exit Pathway Results}

\section{Exit Pathway Northeast of PGDP farther than $\mathbf{3 0 0 0}$ feet from site}

Too few data points for the exit pathway northeast of PGDP farther than 3000 feet from the site exist to interpret any clear trends. Technetium-99 activities were below or near quantifiable limits. Two exceptions were MW135 and MW137. Technetium-99 activities in these wells could be attributable to their proximity to the northwest plume; however, these activities were well below regulatory standards. Other ${ }^{99} \mathrm{Tc}$ activities were below or near quantifiable limits. Data from the exit pathway northeast of PGDP farther than 3000 feet from site indicate no increases or decreases in TCE concentration. (See Figs. 9.30 through 9.33.)

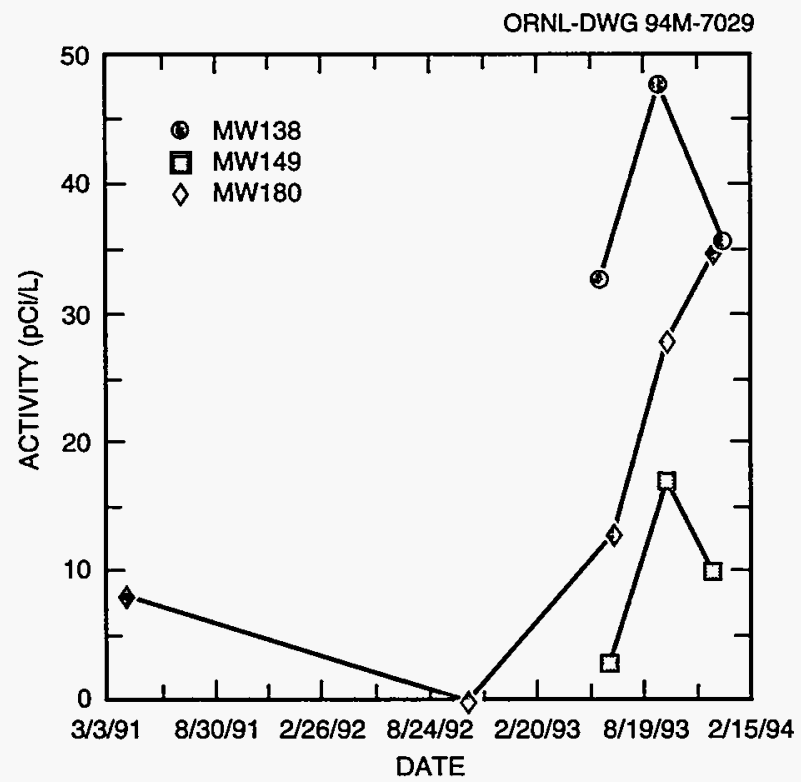

Fig. 9.30. Exit pathway ${ }^{99} \mathrm{Tc}$ results in the UCRS-northeast of PGDP farther than $3000 \mathrm{ft}$ from the site.

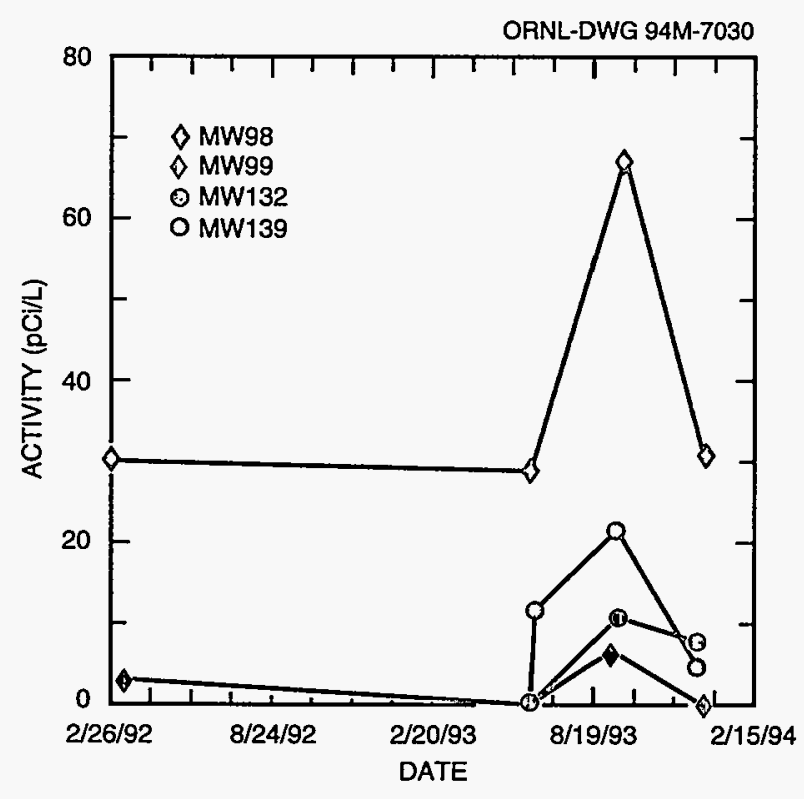

Fig. 9.31. Exit pathway ${ }^{99} \mathrm{Tc}$ results in the RGA-northeast of PGDP farther than $3000 \mathrm{ft}$ from the site (plot 1). 


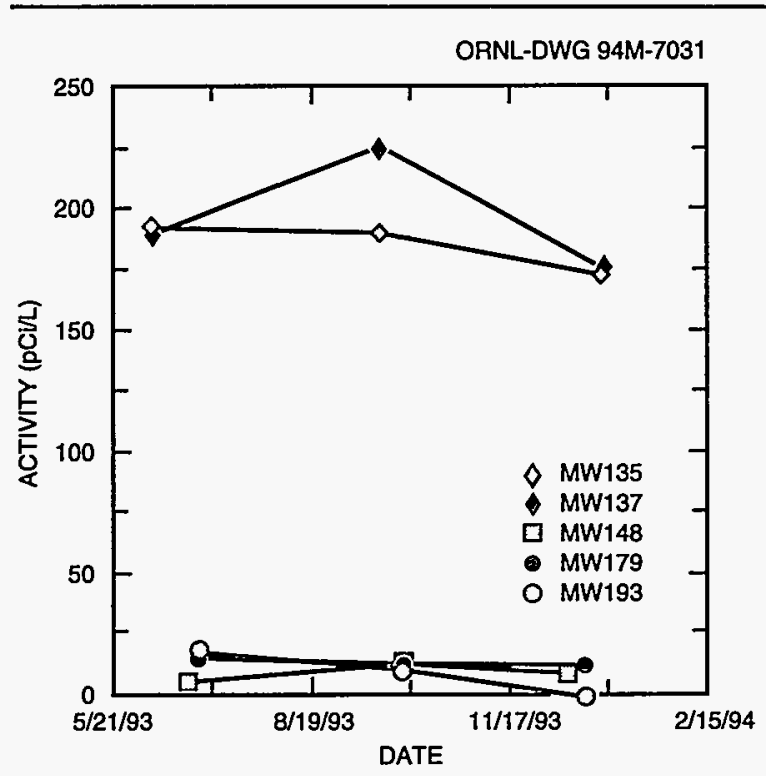

Fig. 9.32. Exit pathway ${ }^{99} \mathrm{Tc}$ results in the RGA - northeast of PGDP farther than $3000 \mathrm{ft}$ from the site (plot 2). Two values, $415 \mathrm{pCi} / \mathrm{L}$ on April 5 , 1991, and $16 \mathrm{pCi} / \mathrm{L}$ on May 15, 1991, for MW179 and MW193, respectively, were omitted to clarify the graph.

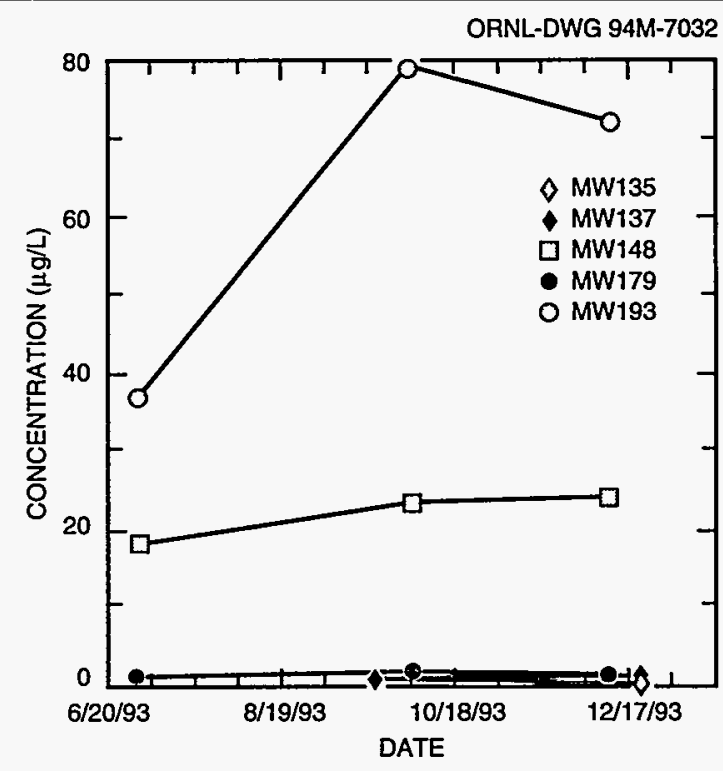

Fig. 9.33. Exit pathway TCE results in the RGA-northeast of PGDP farther than $3000 \mathrm{ft}$ from the site (plot 2). One value, $50 \mathrm{\mu g} / \mathrm{L}$ on May 14, 1991, was omitted from MW193 to clarify the graph.

\section{Exit Pathway Northeast of PGDP up to $\mathbf{3 0 0 0}$ feet from site}

MW128 in the exit pathway northeast of PGDP up to 3000 feet from site appeared to show an increase in ${ }^{99} \mathrm{Tc}$ activity, but too few data points exist to establish a definite trend. In addition, only one data point was above quantifiable levels. MW181 appears to show a decrease in ${ }^{99} \mathrm{Tc}$ activity, but again, too few data points exist to establish a definite trend. All other ${ }^{99} \mathrm{Tc}$ activities were below or near quantifiable limits. Data from the exit pathway northeast of PGDP up to 3000 feet from site indicate no increases or decreases in TCE concentration. (See Figs. 9.34 through 9.36.)

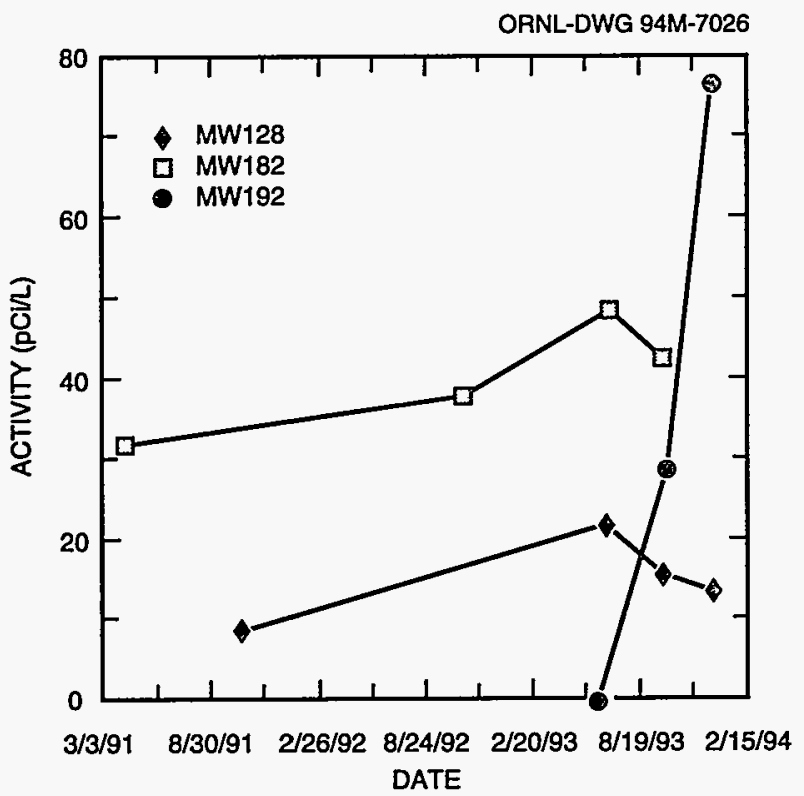

Fig. 9.34. Exit pathway ${ }^{99} \mathrm{Tc}$ results in the UCRS-northeast of PGDP up to $3000 \mathrm{ft}$ from the site.

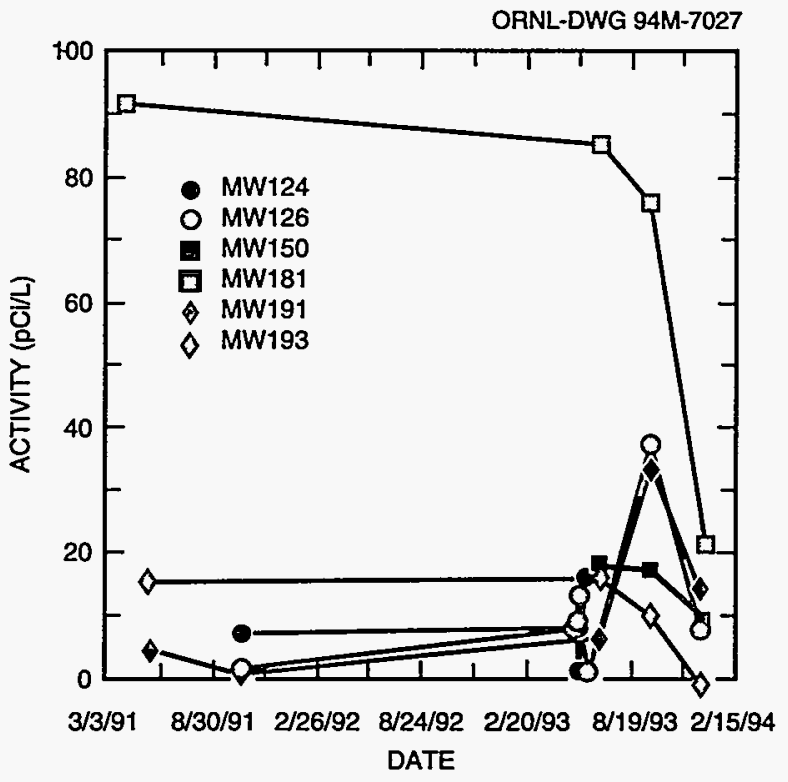

Fig. 9.35. Exit pathway ${ }^{99} \mathrm{Tc}$ results in the RGA-northeast of PGDP up to $3000 \mathrm{ft}$ from the site. 


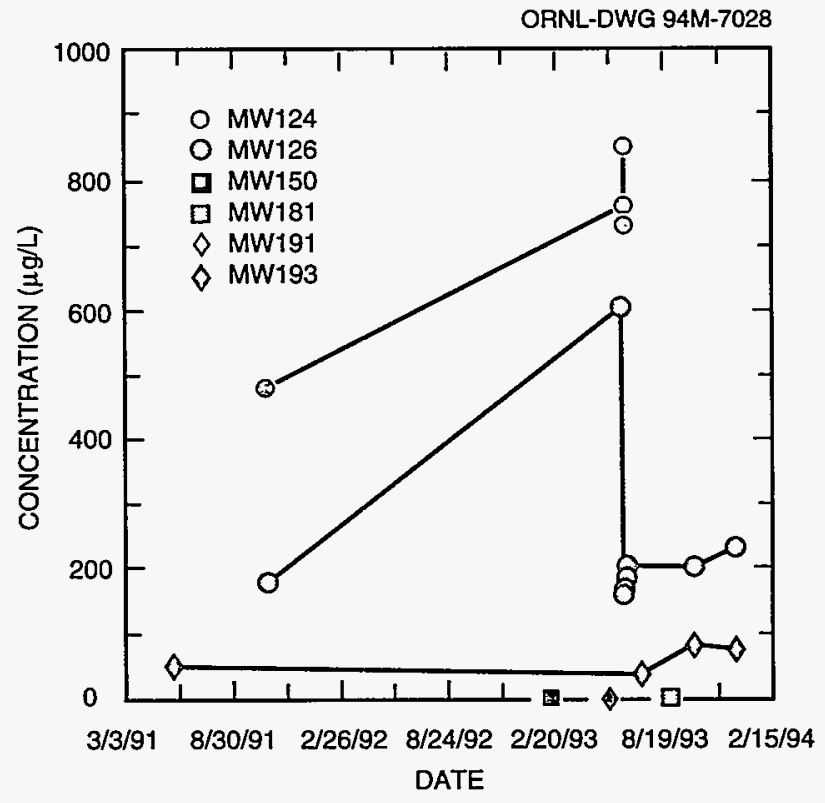

Fig. 9.36. Exit pathway TCE results in the RGA-northeast of PGDP up to $3000 \mathrm{ft}$ from the site.

\section{Exit Pathway Northeast Corner of PGDP}

With the exception of MW166, ${ }^{99} \mathrm{Tc}$ activities in the exit pathway northeast corner of PGDP were below or near quantifiable limits. Too few data points exist to establish an increasing ${ }^{99} \mathrm{Tc}$ trend for MW166. Data from the exit pathway northeast of PGDP showed no indication of increases or decreases in TCE concentration. (See Figs. 9.37 through 9.40.)

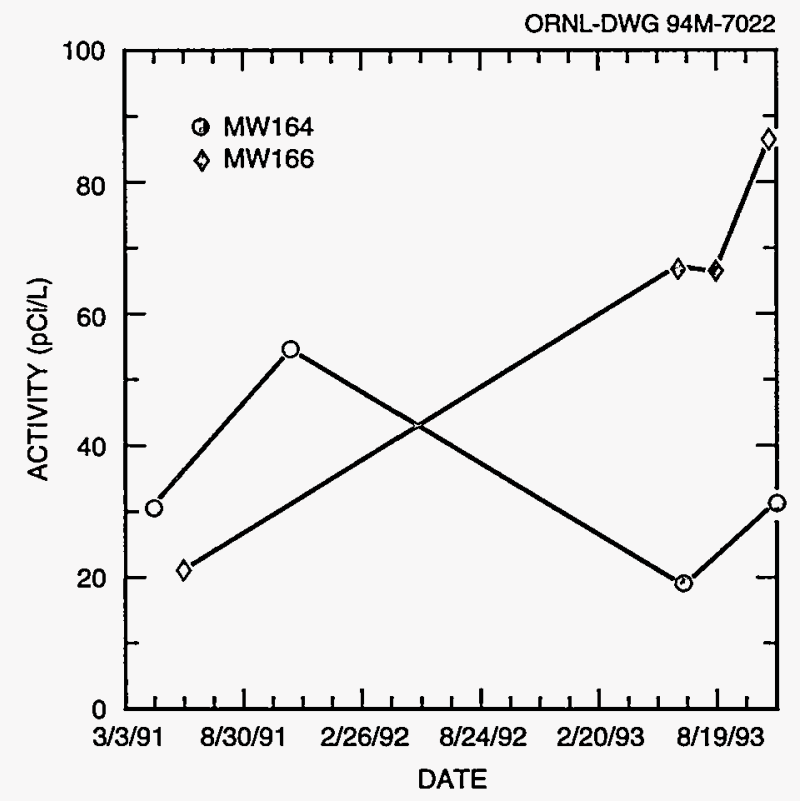

Fig. 9.37. Exit pathway ${ }^{99} \mathrm{Tc}$ results in the UCRS-northeast corner of PGDP.

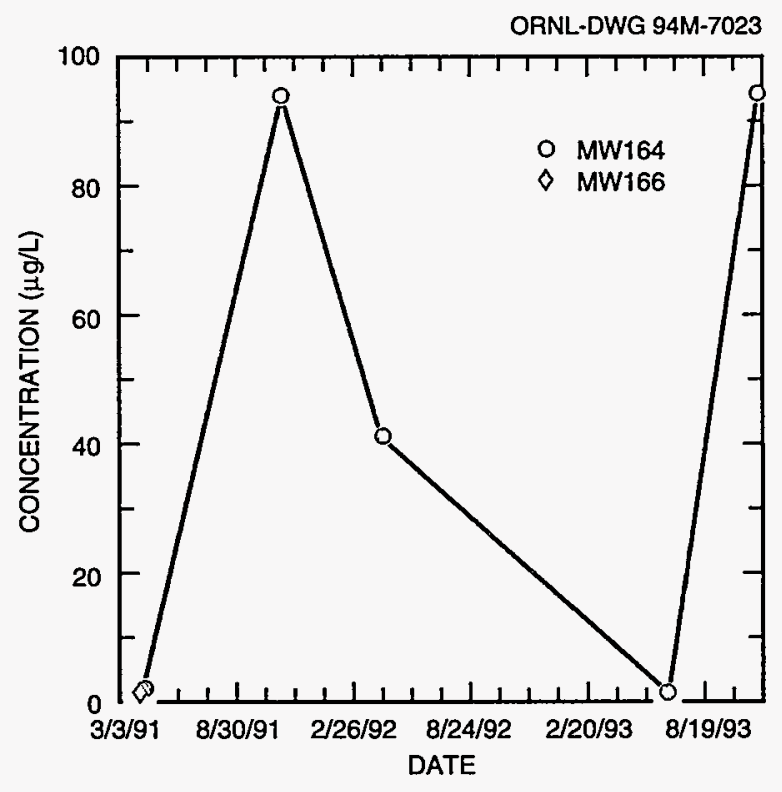

Fig. 9.38. Exit pathway TCE results in the UCRS-northeast corner of PGDP.

\section{9-28 Groundwater}




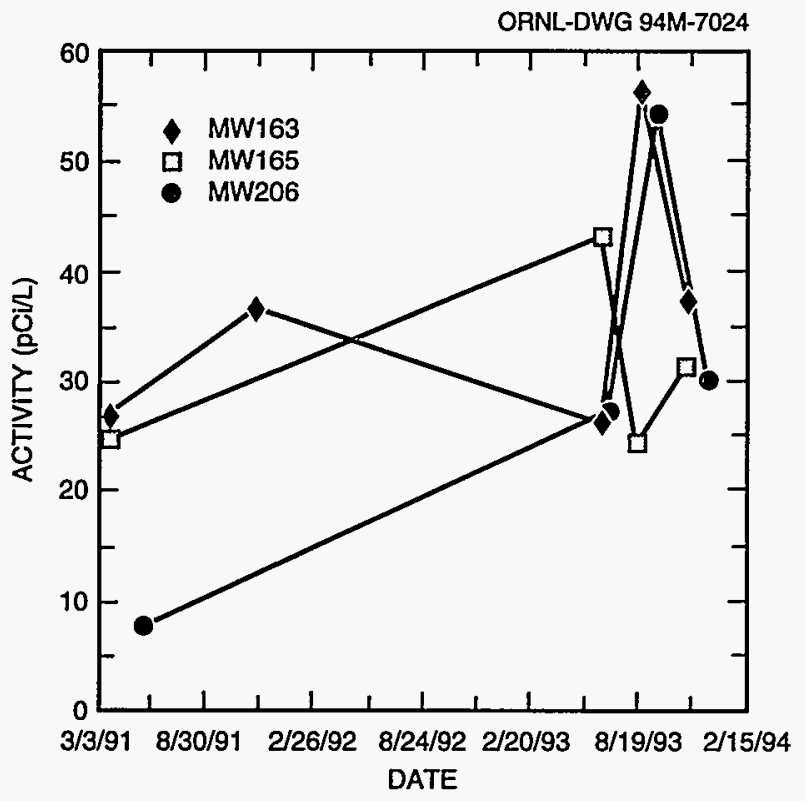

Fig. 9.39. Exit pathway ${ }^{99} \mathrm{Tc}$ results in the RGA-northeast corner of PGDP.

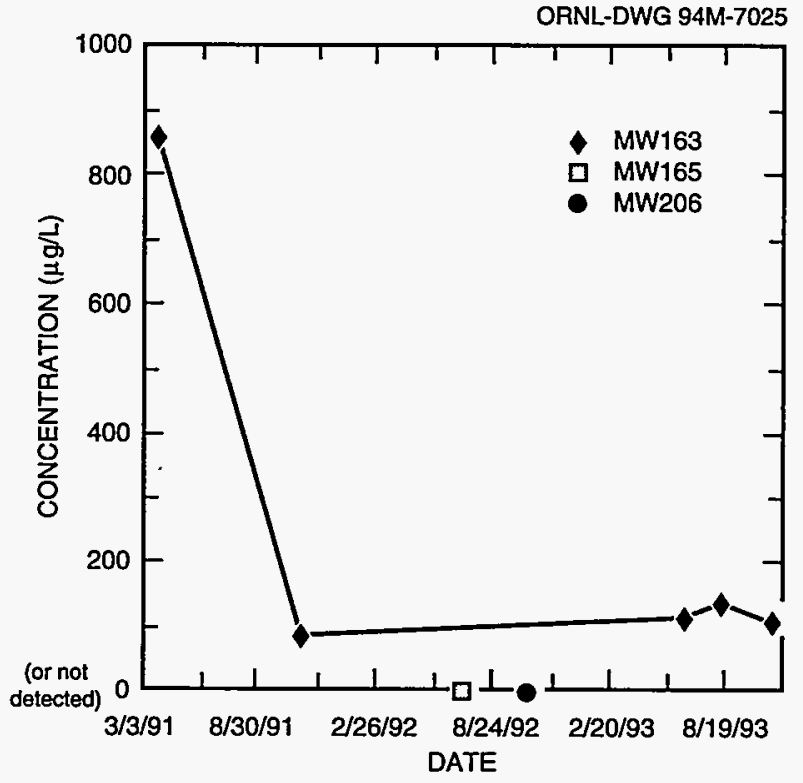

Fig. 9.40. Exit pathway TCE results in the RGA-northeast corner of PGDP.

\section{Exit Pathway North Central Region of PGDP}

Too few data points exist for the exit pathway in the north central region of PGDP to establish any definite trends. Elevated TCE concentrations and ${ }^{99} \mathrm{Tc}$ activities indicate that this area of the plant is the source area for several plumes. (See Figs. 9.41 through 9.44.)

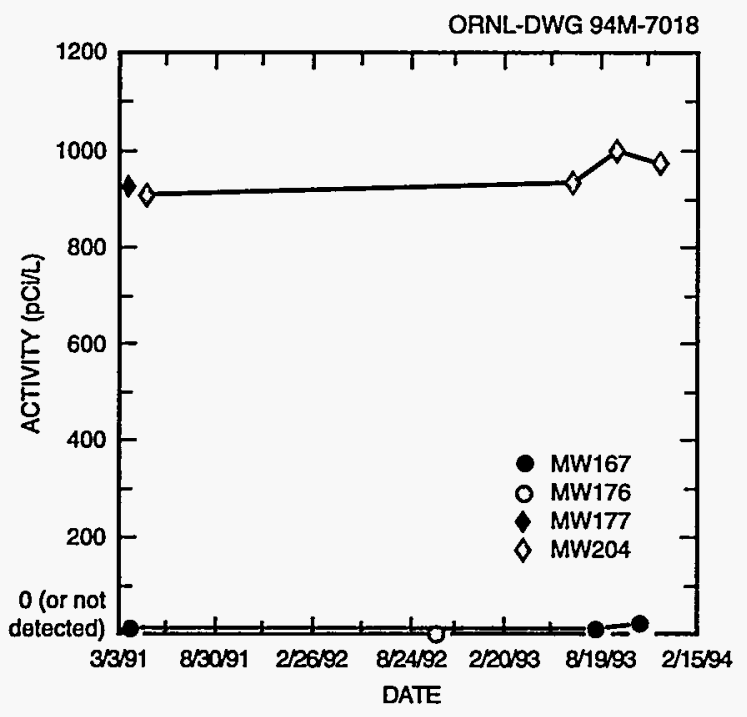

Fig. 9.41. Exit pathway ${ }^{99} \mathrm{Tc}$ results in the UCRS - north central region of PGDP.

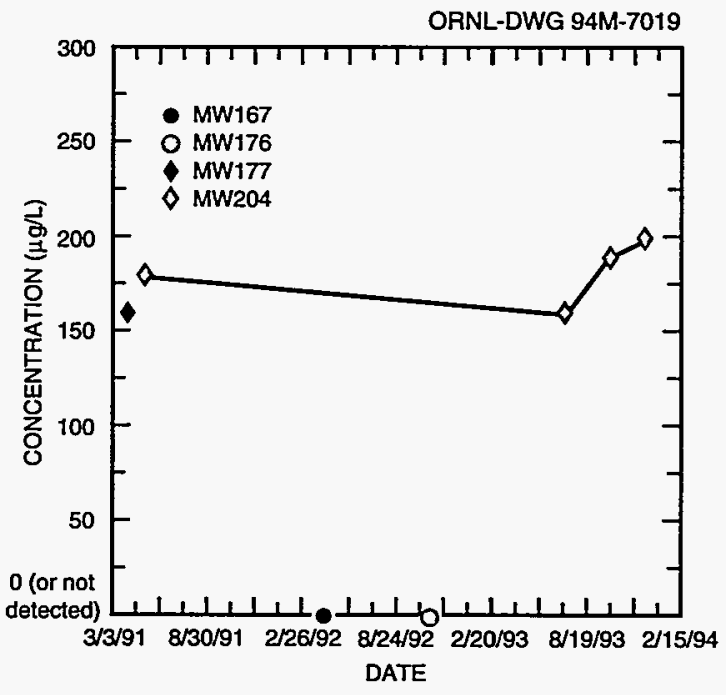

Fig. 9.42. Exit pathway TCE results in the UCRS-north central region of PGDP. 
ORNL-DWG 94M-7020

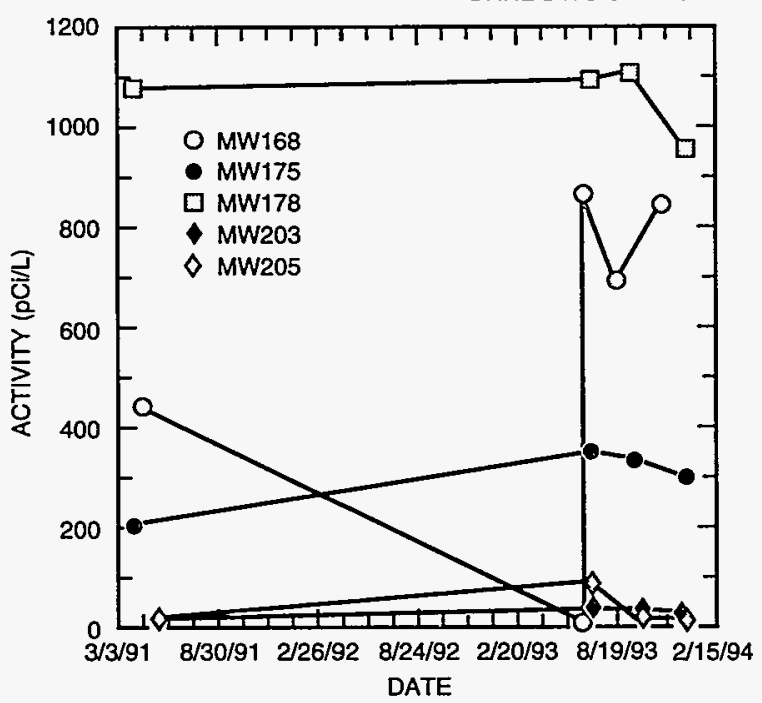

Fig. 9.43. Exit pathway ${ }^{99} \mathrm{Tc}$ results in the RGA-north central region of PGDP.
ORNL-DWG 94M-7021

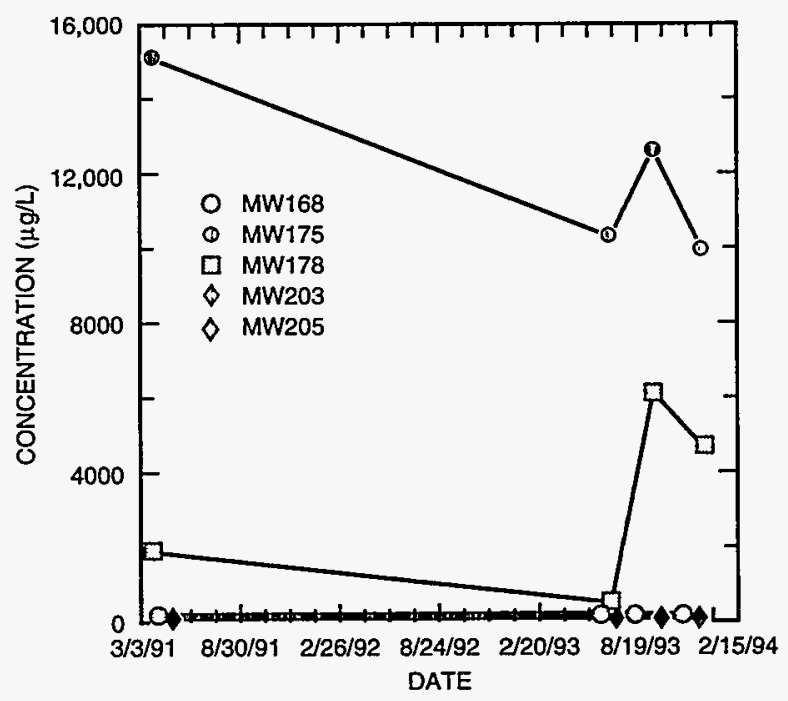

Fig. 9.44. Exit pathway TCE results in the RGA-north central region of PGDP.

\section{Exit Pathway Northwest of PGDP farther than 3000 feet from site}

All ${ }^{99} \mathrm{Tc}$ activities for the exit pathway northwest of PGDP farther than 3000 feet from site were below or near quantifiable levels, except for MW200. Low TCE concentrations in this well appear to indicate a separate ${ }^{99} \mathrm{Tc}$ plume. All TCE concentrations in this area were below drinking water standards. (See Figs. 9.45 through 9.47.)

ORNL-DWG 94M-7015

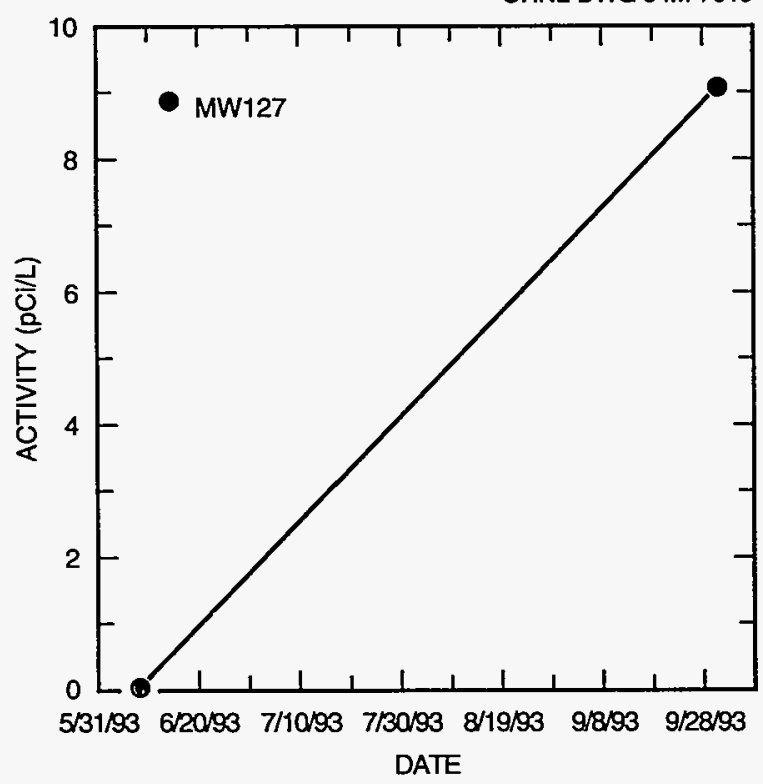

Fig. 9.45. Exit pathway ${ }^{99} \mathrm{Tc}$ results in the UCRS-northwest of PGDP farther than $3000 \mathrm{ft}$ from the site.

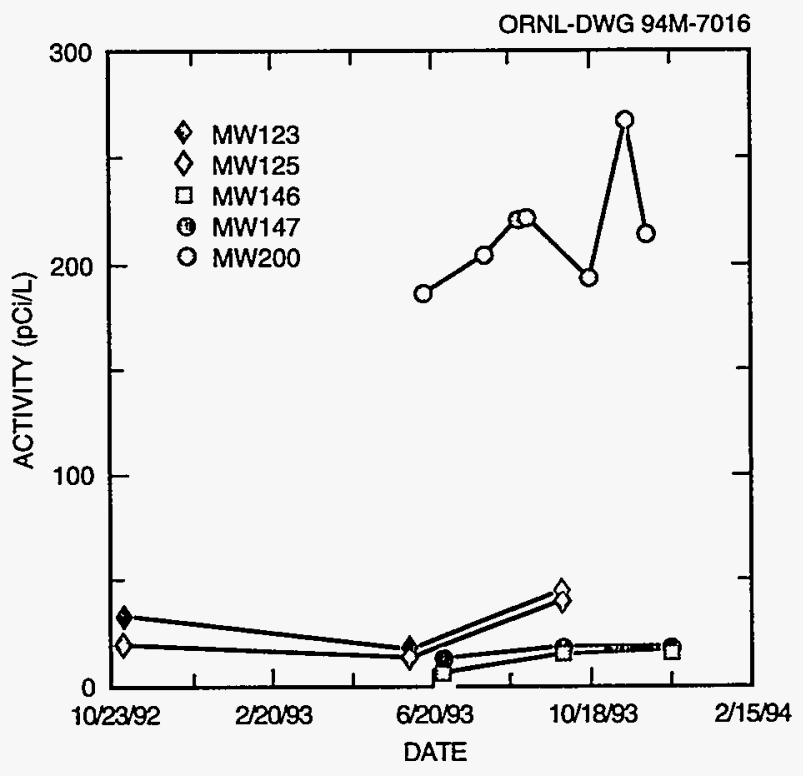

Fig. 9.46. Exit pathway ${ }^{99} \mathrm{Tc}$ results in the RGA-northwest of PGDP farther than $3000 \mathrm{ft}$ from the site. 


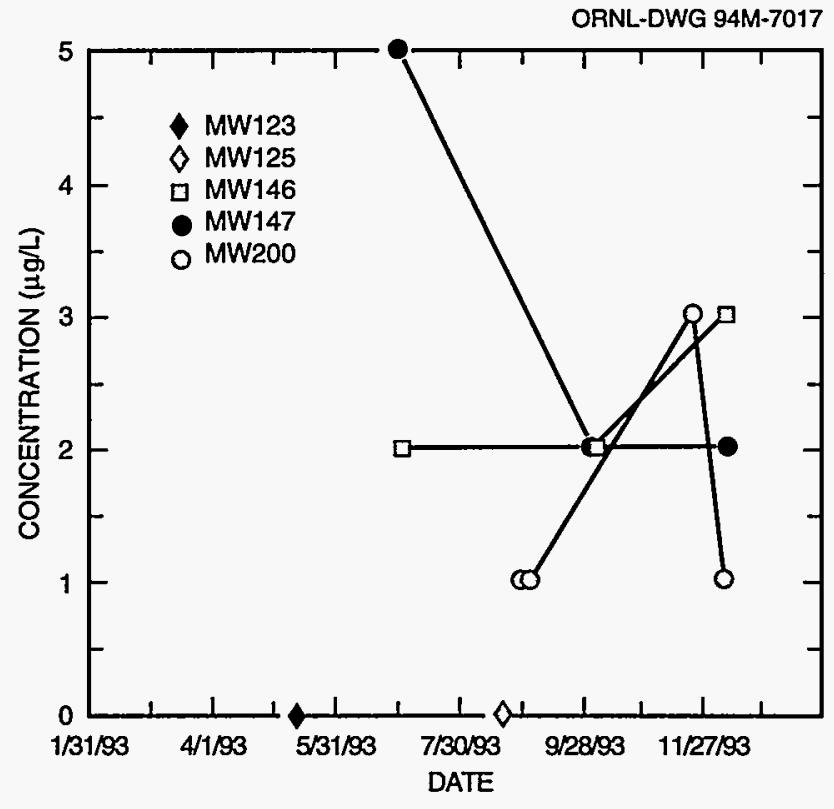

Fig. 9.47. Exit pathway TCE results in the RGA-northwest of PGDP farther than $3000 \mathrm{ft}$ from the site.

\section{Exit Pathway Northwest of PGDP up to $\mathbf{3 0 0 0}$ feet from site}

MW197 appears to be increasing in both ${ }^{99} \mathrm{Tc}$ and TCE. The similar trends for the two analytes may represent a single source. Except for anomalous values, all other values for TCE and ${ }^{99} \mathrm{Tc}$ in the exit pathway northwest of PGDP up to 3000 feet from site were either below quantifiable limits or not detected. (See Figs. 9.48 through 9.51.)

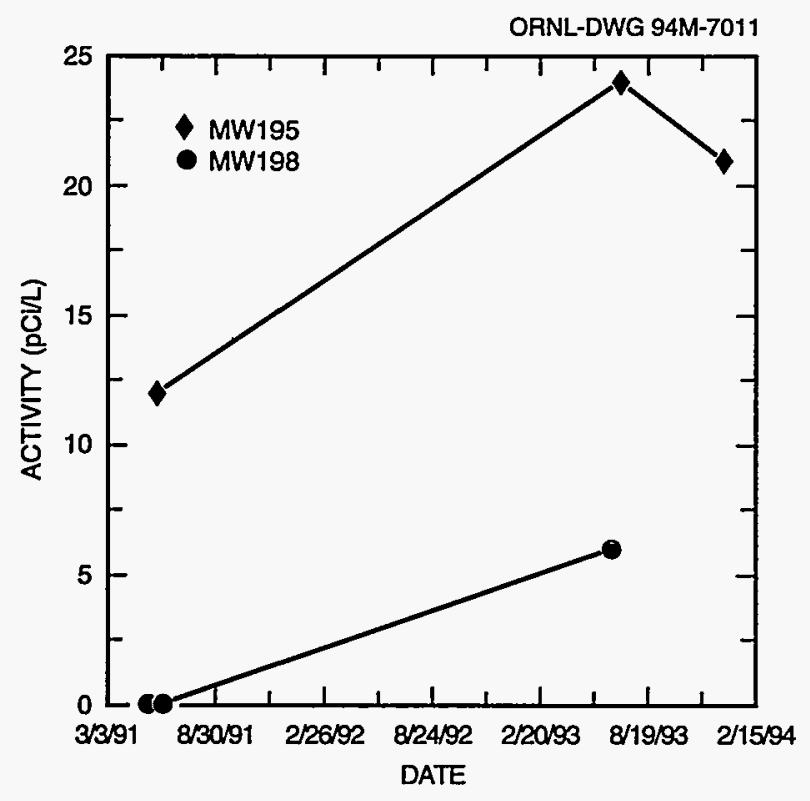

Fig. 9.48. Exit pathway ${ }^{99} \mathrm{Tc}$ results in the UCRS-northwest of PGDP up to $3000 \mathrm{ft}$ from the site.

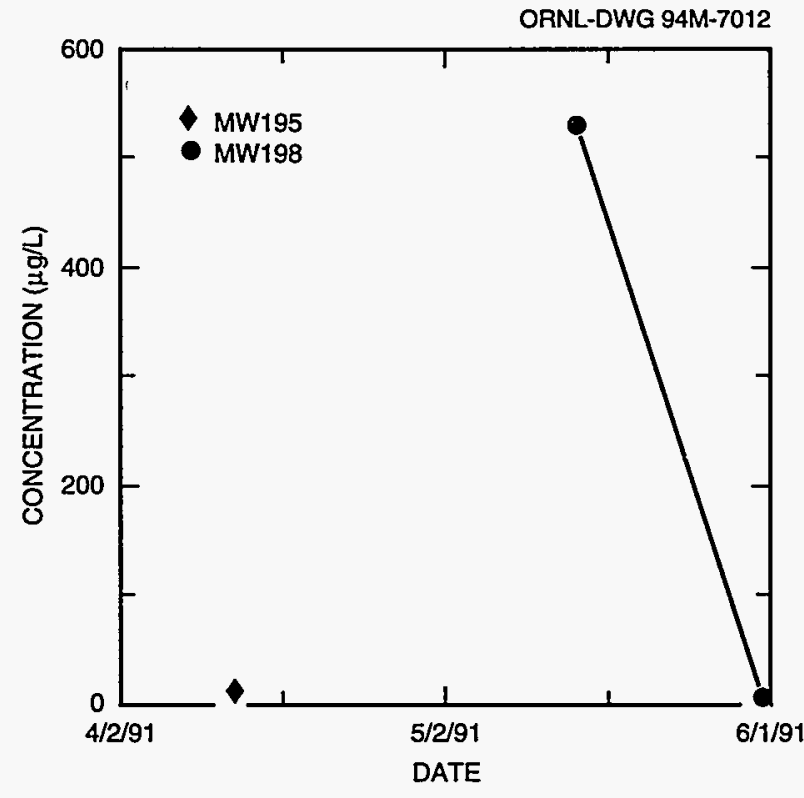

Fig. 9.49. Exit pathway TCE results in the UCRS-northwest of PGDP up to $3000 \mathrm{ft}$ from the site. 
ORNL-DWG 94M-7013

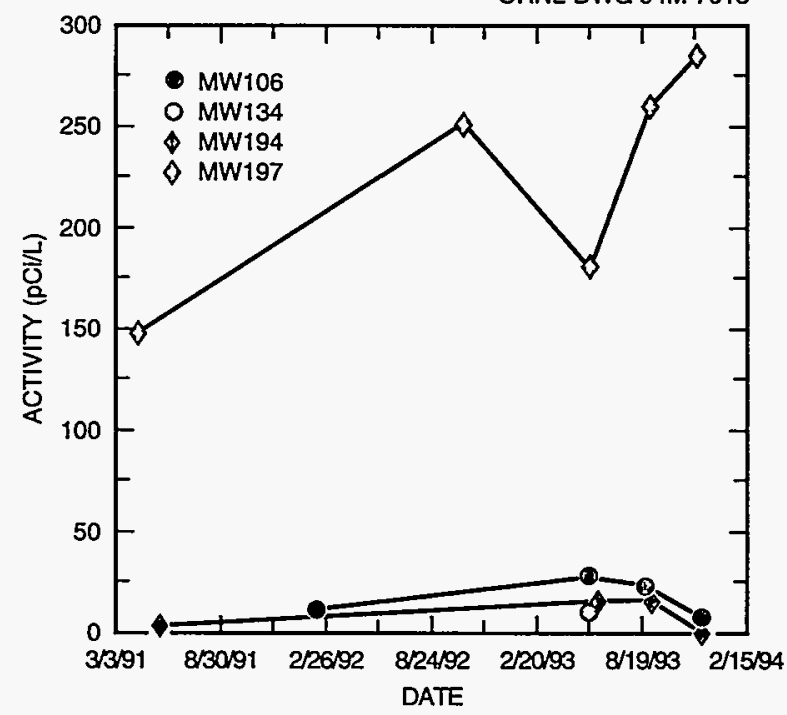

Fig. 9.50. Exit pathway ${ }^{99} \mathrm{Tc}$ results in the RGA-northwest of PGDP up to $3000 \mathrm{ft}$ from the site. One value of ${ }^{99} \mathrm{Tc}, 870 \mathrm{pCi} / \mathrm{L}$ on October 27 , 1992, was omitted from MW134 to clarify the graph.

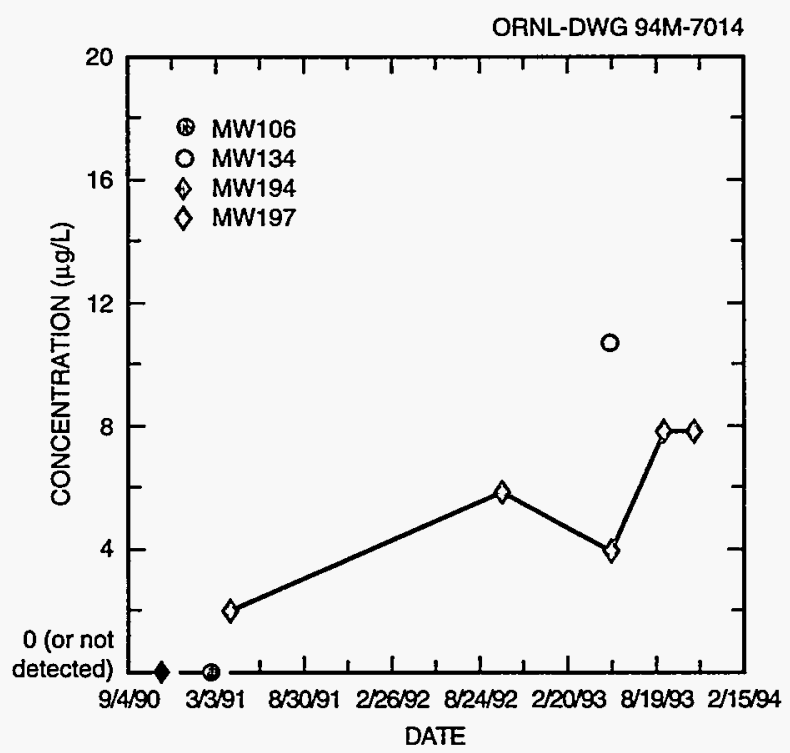

Fig. 9.51. Exit pathway TCE results in the RGA-northwest of PGDP up to $3000 \mathrm{ft}$ from the site. One value of TCE, $1600 \mu \mathrm{g} / \mathrm{L}$ on October 27 , 1992 , was omitted from MW134 to clarify the graph.

\section{Exit Pathway Northwest Corner of PGDP}

Except for anomalous values, all values for TCE and ${ }^{99} \mathrm{TC}$ in the exit pathway northwest corner of PGDP were either below quantifiable limits or not detected. (See Figs. 9.52 and 9.53.)

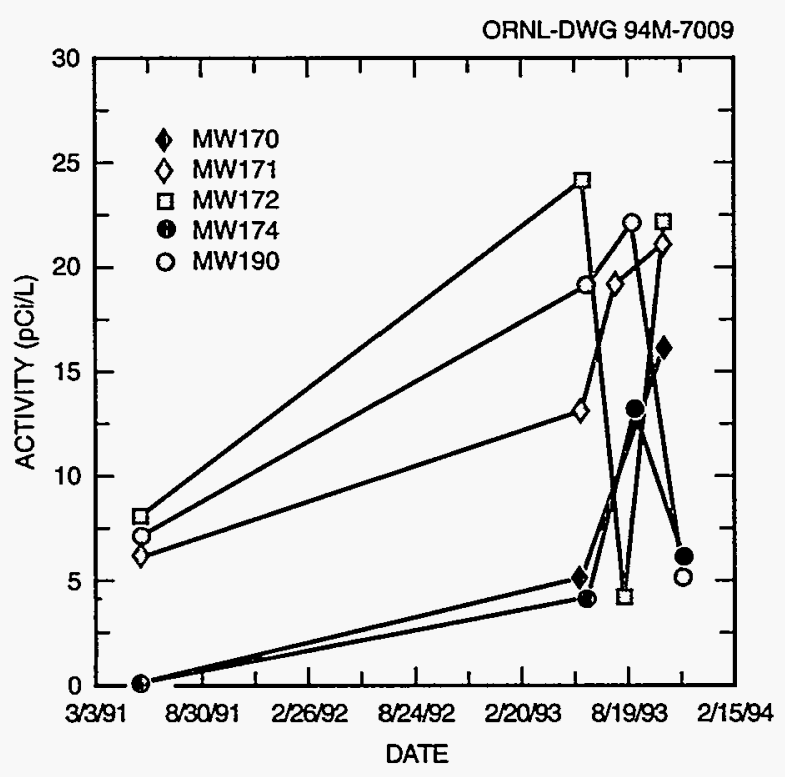

Fig. 9.52. Exit pathway ${ }^{99} \mathrm{Tc}$ results in the UCRS-northwest corner of PGDP. One value, $137 \mathrm{pCi} / \mathrm{L}$ on August 24, 1993, was omitted from MW170 to clarify the graph.

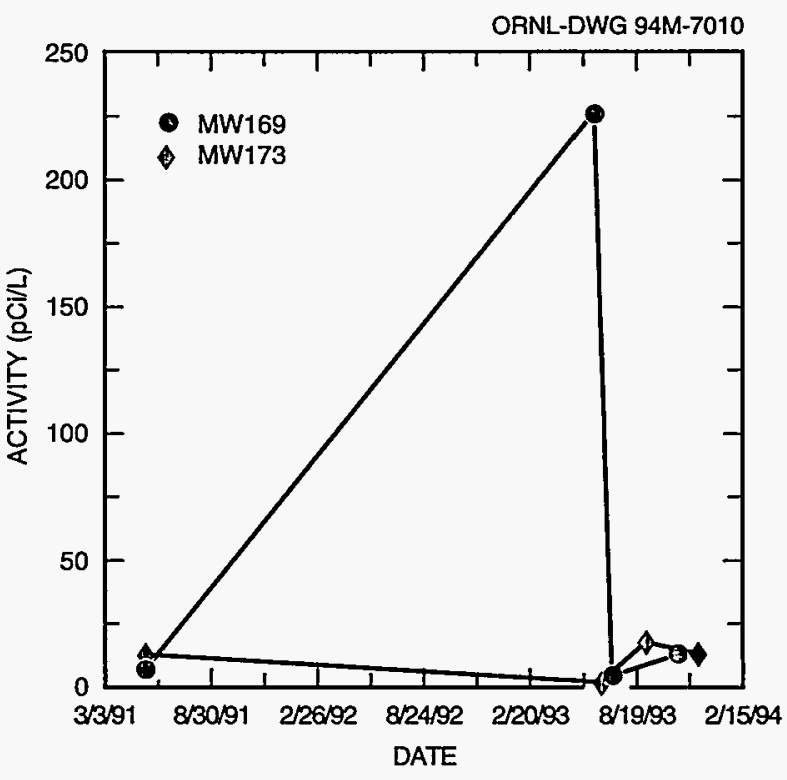

Fig. 9.53. Exit pathway ${ }^{99} \mathrm{Tc}$ results in the RGA-northwest corner of PGDP. 


\section{Exit Pathway West Side of PGDP}

A decreasing trend is evident in MW154 for both TCE and ${ }^{99} \mathrm{Tc}$. These analytes may also be decreasing in MW162, but too few data points exist to determine a trend. Too little data exist to determine an increase in TCE concentrations for MW161 also. Data from the exit pathway to the west of PGDP show no indication of increases or decreases in TCE concentration. All other ${ }^{99} \mathrm{Tc}$ activities (with the exception of anomalous values) were below or near quantifiable limits. (See Figs. 9.54 through 9.57.)

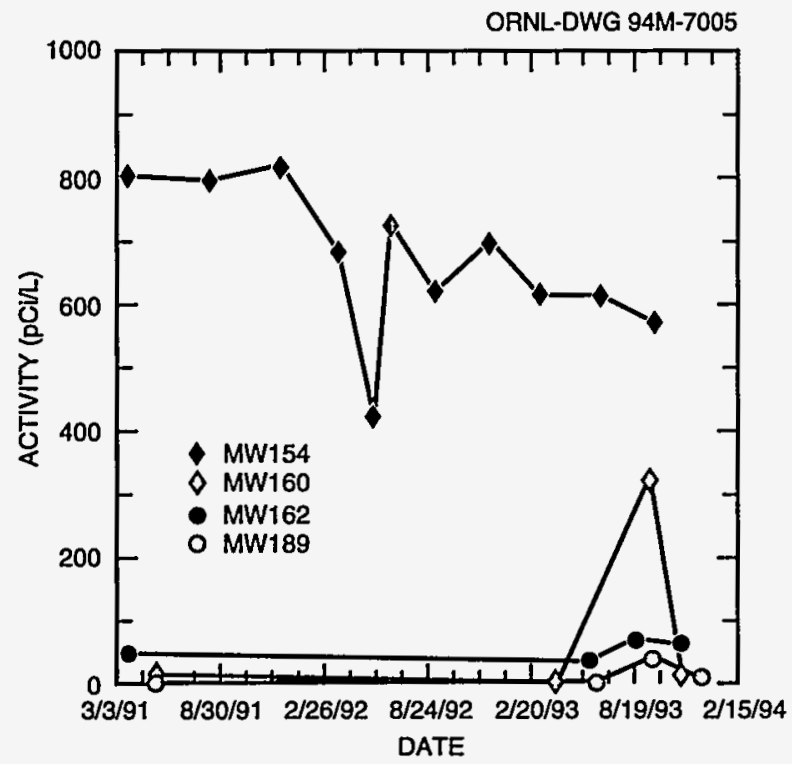

Fig. 9.54. Exit pathway ${ }^{99} \mathrm{Tc}$ results in the UCRS-west side of PGDP.

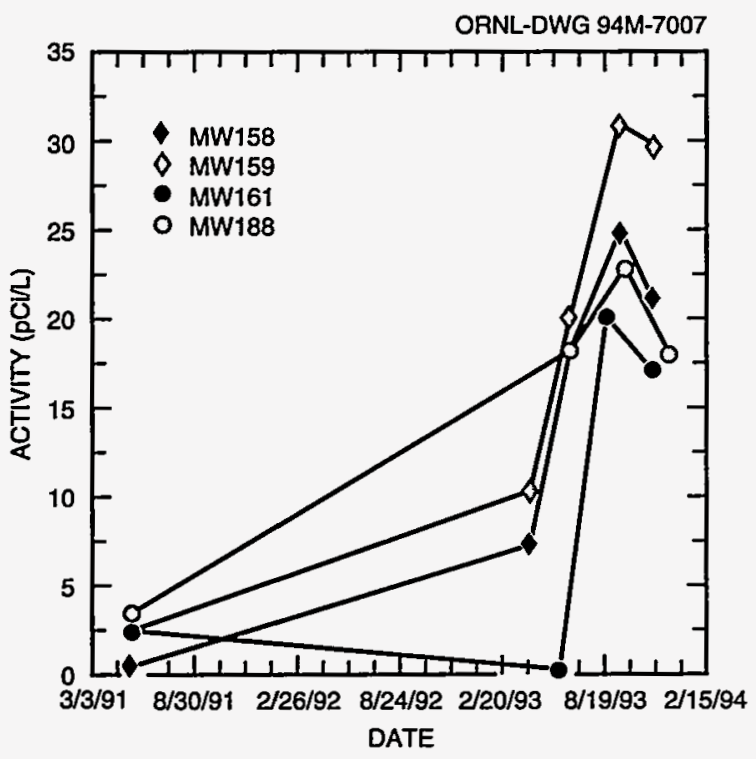

Fig. 9.56. Exit pathway ${ }^{99} \mathrm{Tc}$ results in the RGA-west side of PGDP.

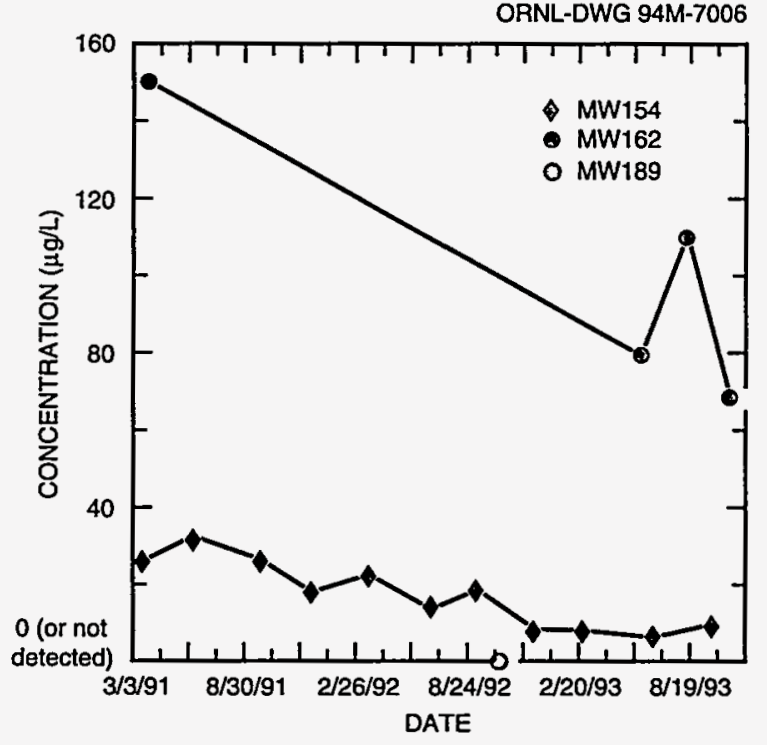

Fig. 9.55. Exit pathway TCE results in the UCRS-west side of PGDP. MW160 was omitted from the graph; its plot is included with the DNAPL results.

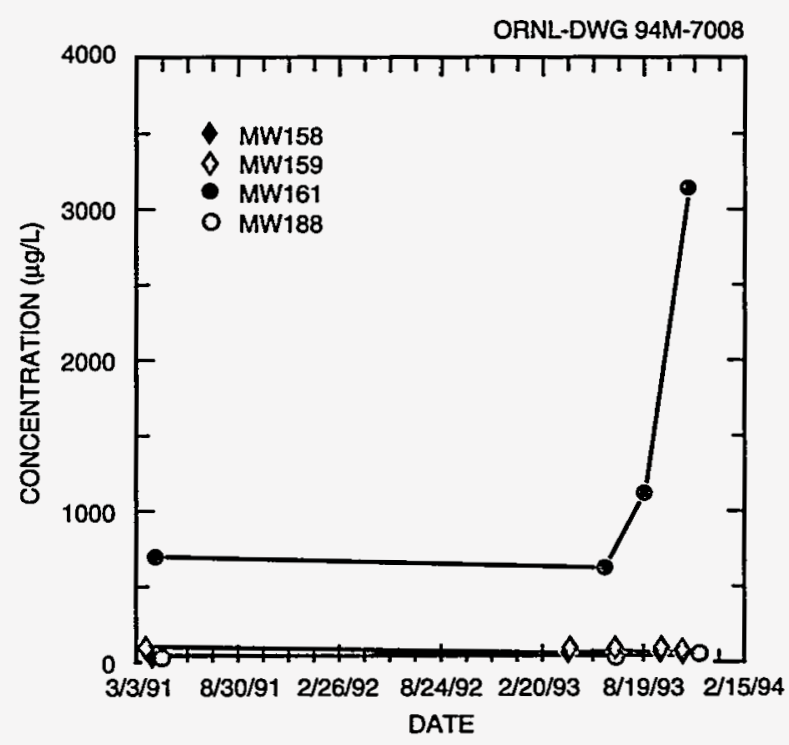

Fig. 9.57. Exit pathway TCE results in the RGA-west side of PGDP. 


\section{Exit Pathway Southwest Corner Off-Site}

All values for TCE and ${ }^{99} \mathrm{Tc}$ in the exit pathway southwest corner off-site were either below quantifiable limits or not detected (see Fig. 9.58).

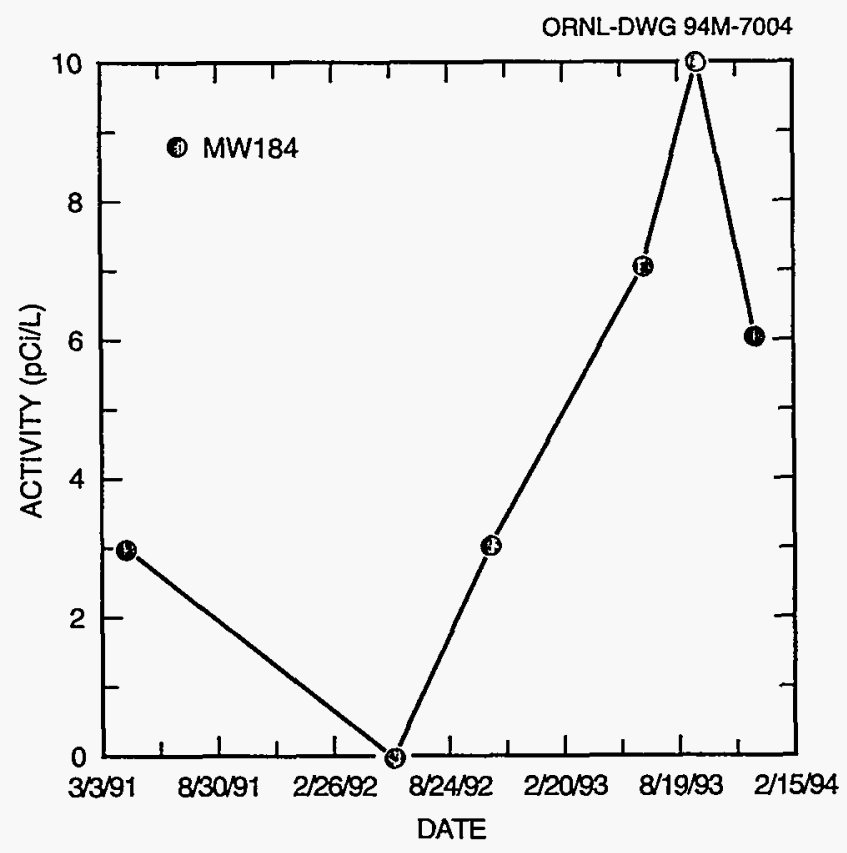

Fig. 9.58. Exit pathway ${ }^{99} \mathrm{Tc}$ results in the UCRS-southwest corner off-site. 


\title{
10. Quality Assurance
}

M. G. Guhy and W. D. Malis

\begin{abstract}
Paducah Gaseous Diffusion Plant maintains a quality assurance/quality control program to verify the integrity of data generated within the environmental monitoring program. Monitoring and sampling organizations at Paducah select sampling methods, instruments, locations, schedules, and other sampling and monitoring criteria based on applicable guidelines from various established authorities and on input from compliance and analytical organizations at the plant. Chain-of-custody procedures are followed and documented from the point of sampling until analysis or disposal of the sample.
\end{abstract}

\section{INTRODUCTION}

The Environmental Monitoring Department at Paducah Gaseous Diffusion Plant (PGDP) maintains a quality assurance/quality control $(\mathrm{QA} / \mathrm{QC})$ program to verify the integrity of data generated within the environmental monitoring program. Each aspect of the monitoring program, from sample collection to data reporting, must address $\mathrm{QA}, \mathrm{QC}$, and quality assessment standards.

U.S. Department of Energy (DOE) Order 5700.6C, Quality Assurance; state and federal regulations; and documentation from the U.S. Environmental Protection Agency (EPA), the American National Standards Institute, the American Society of Mechanical Engineers, and the American Society for Quality Control establish requirements and guidelines for the QA/QC program at PGDP. The QA/QC program specifies organizational, inspection, and programmatic elements to control equipment, design, documents, nonconformances, and records. Emphasis is placed on planning, audits, records, and corrective actions.

To ensure compliance with regulations and to provide overall quality requirements for monitoring programs, the Environmental Monitoring Department developed the Quality Assurance Plan for the Environmental Monitoring Department. This document defines the relationship of each element of the environmental monitoring program to key $\mathrm{QA} / \mathrm{QC}$ requirements. Training requirements, sample custody, procedures, instrument calibration, and maintenance are a few of the subjects discussed in the document. Roles and responsibilities of the Environmental Monitoring Department are also included, as well as the Environmental Monitoring Department's relationship with customers and support groups. Figure 10.1 shows the current organization and the responsibilities of the 22 positions in the department. The Quality Assurance Section within the Environmental Monitoring Department performs a variety of functions critical to the environmental monitoring program. Included in the responsibilities of the section are data validation, calibration control, and development of data quality objectives. Other roles of the Quality Assurance Section include preparation of procedures and quality assurance and health and safety plans, as well as assisting in the development of training modules.

\section{FIELD SAMPLING AND MONITORING}

\section{Basic Concepts and Practices}

From the point of conception of any sampling program, QA/QC plays an important role. Each monitoring or sampling organization plans a project, sets objectives, identifies responsibilities, and selects sampling methods and the appropriate sampling instruments or devices according to use and cleaning practices recommended by the American Society for Testing and Materials, the EPA, or other established authorities. The number of samples, location of sampling sites, sampling methods, sampling schedule, and coordination of sampling and analytical resources to meet critical completion times must all be decided. The rationale for these and other decisions is mainly the responsibility of the sampling organization, which receives input from compliance and analytical organizations. Sampling plans and field documentation are prepared as needed.

Chain-of-custody documentation is maintained from the point of sampling, and samples are properly protected until they are placed in the custody of analytical laboratory control programs. In the laboratory, chainof-custody procedures are followed until a sample is analyzed. For hazardous waste samples, chain-of-custody 
ORNL-DWG 94M-8137R

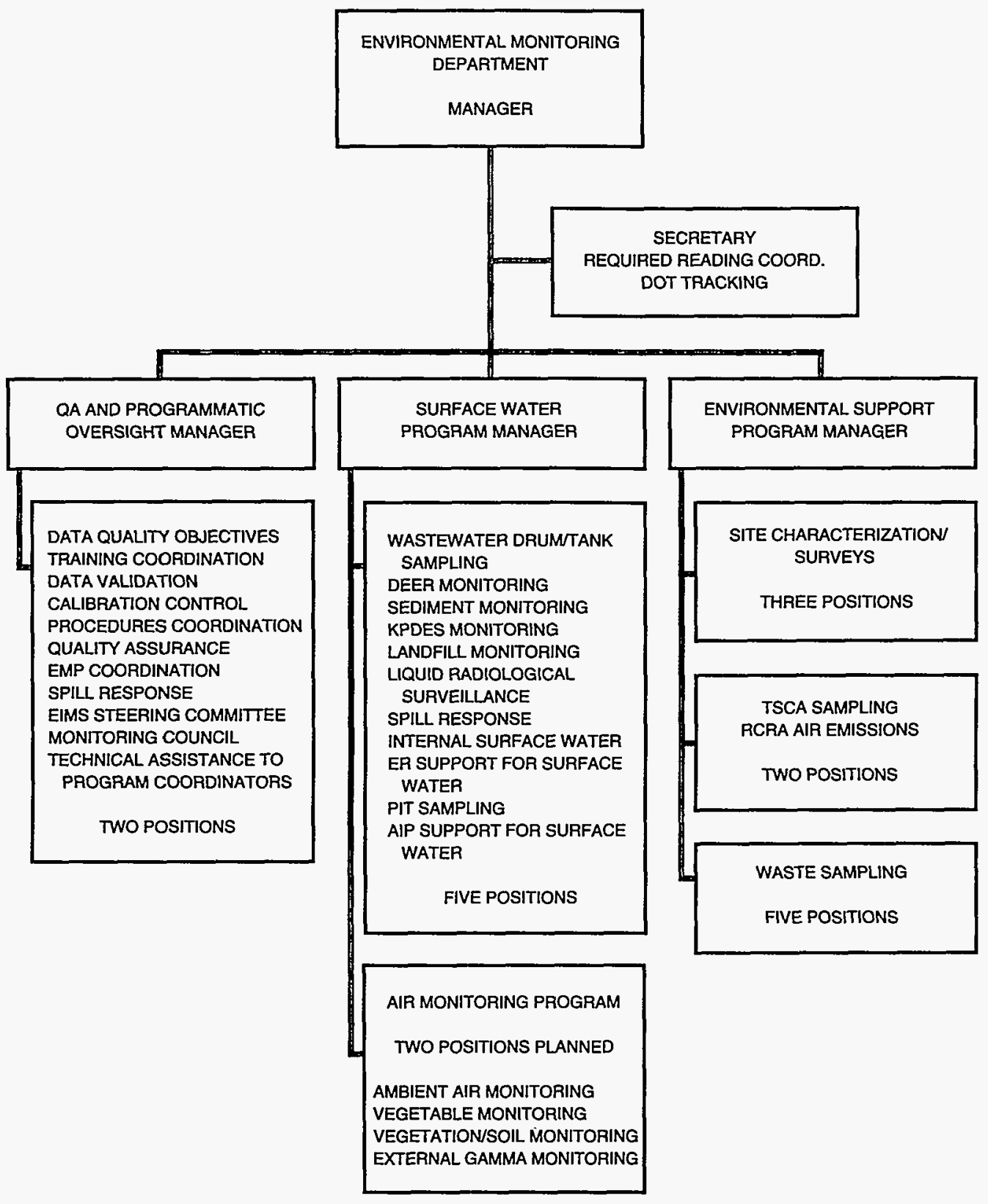

Fig. 10.1. Environmental Monitoring Department organization chart. 
procedures are maintained to the point of sample disposal. The performance of all field analytical procedures is documented using EPA-approved methods when available.

The Quality Assurance Plan for monitoring activities specifies a target rate for QA/QC on field samples. . Routine environmental monitoring has a target of $10 \%$, whereas programs under the Resource Conservation and Recovery Act have a target of $5 \%$. These rates are those recommended by regulatory guidance for each of the programs. The following shows the types of QA/QC samples used and what area is controlled:

\begin{tabular}{lll} 
Monitoring QA/QC & Laboratory QA/QC & $\begin{array}{c}\text { Monitoring/lab QA performed } \\
\text { by the laboratory }\end{array}$ \\
\hline Duplicates & Replicates & Control samples \\
Trip blanks & Reagent blanks & Performance evaluations \\
Equipment blanks & Matrix spikes & Measurement control \\
Equipment rinsates & & Programs \\
\hline
\end{tabular}

Monitoring QA/QC samples are chosen from the preceding list such that a combination meets the specified rate. The mixture varies with the activity performed.

\section{ANALYTICAL QA}

The analytical laboratories of PGDP continue a long tradition of QA. Such terms as sound methodology, safe practices, analytical recovery, and QC are well defined. Also well established is the use of statistical methods to establish precision, accuracy, lowest concentration reported, and minimum detection level. Since the beginning of operations at PGDP, the analytical laboratories have been involved in the handling and analysis of materials of high purity and hazardous materials, for which strict accountability is required. QA is, therefore, a daily responsibility.

After receiving samples from the sampling group or the sample transporter, the laboratory custodian assumes responsibility for proper protection and handling of the samples. Using guidance from the EPA, the laboratories document the steps in handling, analysis, and approval of results. The performance of all analytical procedures is documented using EPA-approved methods when they are available.

A key feature in analytical QA is QC. PGDP participates in programs that are internal to the laboratory (i.e., internal controls), internal to PGDP but external to the laboratory (i.e., external controls), and external to the plant (i.e., independent controls).

\section{Internal QC}

All analytical activities are supported by the use of standard, or reference, materials. The compositions of these materials are well known and are used in calibration of instruments, method standardization, spike additions for recovery testing, and other practices. Certified standards from the National Institute of Standards and Technology, the EPA, or other DOE laboratories are often used in such work.

These internal programs are the mainstay of analytical $\mathrm{QC}$ and the basis for ensuring reliable results on a daily basis and between batches. The total effort in these programs is at least $10 \%$ of the total laboratory effort (in accordance with EPA expectations) and probably reaches $20 \%$ in some activities.

The internal QA and QC programs have become major factors in environmental analysis procedures because of the low levels of pollutants measured and the relationships of these measured values to regulatory limits. These QC programs also provide for laboratory analyst training and qualification in the many procedures involved. The daily $\mathrm{QC}$ data are stored in a retrievable manner so that they can be related to the analytical results they support. 


\section{External QC}

The Technical Services Division has a Quality Support Section that is functionally independent of the laboratory. The section administers external QC programs at the request of the analytical laboratories and their customers. Through these programs, the Quality Support Section generates QC samples of known composition and periodically submits these to the laboratory as known controls of unknown value (blind). Many of these programs include computer-generated notices for immediate feedback of performance. Formal reports summarizing statistical evaluation of data, control charts, and results of trend analyses are issued regularly. Results that exceed the 3-sigma alarm limits are investigated and documented in accordance with formal procedures.

\section{Independent QC}

PGDP is directed by DOE and EPA regulators to participate in external QC programs. PGDP also participates in voluntary external programs to provide for improved analytical QC. These programs generate data that are readily recognizable as objective measures, allowing the participating laboratories and government agencies a periodic review of performance. Results that exceed acceptable limits are investigated and documented according to formal procedures. Although participation is mandated, the degree of participation is voluntary so that each laboratory can select parameters of particular interest to that facility. The sources of these programs are the EPA, DOE, and commercial laboratories. The Quality Support Section coordinates and evaluates the results of the independent QC programs, which are discussed in the following.

\section{EPA Discharge Mionitoring Report Quality Assurance Program}

The EPA conducts a national QA program in support of the National Pollutant Discharge Elimination System (NPDES) program. All holders of major NPDES permits are required to participate. The EPA furnishes QC samples annually and evaluates the results. The state of Kentucky monitors PGDP performance in this program. PGDP is required to analyze those parameters on its permit that are included in the Discharge Monitoring Report QA Program. Other parameters may be analyzed on a voluntary basis for documentation or method checking. Of the 15 analyses for 1993,4 results were unacceptable.

\section{Proficiency Environmental Testing Program}

PGDP participates in the Proficiency Environmental Testing Program, a voluntary external measurement control program using samples purchased from Analytical Products Group, Inc. (APG), a commercial supplier. Samples at two concentration levels are analyzed bimonthly and reported to APG. An evaluation report is received in approximately three weeks. Most samples are evaluated by comparing (in standard deviations) the reported value to the mean of the reporting laboratories. Samples for dissolved and suspended solids are compared with the average percent of recovery in the same way. Performance evaluation is derived using the same criteria as those in the EPA Discharge Monitoring Report QA Program. The Quality Support Section maintains control charts on these analyses. Measurements that have unacceptable recoveries of more than 2.58 standard deviations from the mean are investigated to determine the cause. Of 664 measurements made in 1993, 13 were deemed not acceptable.

\section{Proficiency Analytical Testing Program}

PGDP also participates in the Proficiency Analytical Testing Program, an external measurement control program from the National Institute for Occupational Safety and Health. This program targets industrial hygiene analyses but also has application to environmental factors because the concerns in both fields overlap. All 64 measurements performed by PGDP in 1993 were acceptable, and the laboratory maintained a "proficient" rating for all analyses for 1993. 


\section{DOE Environmental Measurements Laboratory Quality Assessment Program}

PGDP participated in the Environmental Measurements Laboratory Measurements Control Program as required by DOE Order 5400.1 . The performance evaluation for this program is determined by using the three ratio ranges given in the Environmental Measurements Laboratory report to determine "acceptable," "marginal," or "not acceptable" results. Of the 34 results reported by PGDP, 2 were not acceptable.

\section{DATA MANAGEMENT}

Data management activities performed for the environmental monitoring program follow the guidelines outlined in the Data and Documents Management Plan. This document presents the various components that constitute the overall data management process and establishes roles and responsibilities. The data generated by these programs are stored in the Environmental Information Management System (EIMS), a consolidated site data system for tracking, management, verification, validation, and reporting of environmental data. The EIMS uses a variety of reference and code lists to ensure consistency and to standardize the presentation of data for users.

EIMS performs a computer-based verification and validation of the field and analytical data that are entered from field logbooks and forms or analytical data packages. The verification procedures check for inconsistencies with the reference and codes tables. Examples of these checks include valid sample type, spelling of the analysis name, units, and appropriate methods. Data that pass all of the verification checks will be compared with validation criteria, which are established by the data generator during the development of the data quality objectives. Examples of these checks include holding time exceedences, comparison with historical statistics, and comparison with regulatory or permit limits. Validation flags are attached to the data as a result of this step. These validation flags are available to persons using the data to aid in assessing how usable the data are. 


\section{Appendix A: Radiation}

This appendix gives basic facts about radiation. The information is intended to be a basis for understanding the dose associated with releases from the Paducah Gaseous Diffusion Plant, not a comprehensive discussion of radiation and its effects on the environment and biological systems. The McGraw-Hill dictionary defines radiation and radioactivity thusly:

radiation-1. The emission and propagation of waves transmitting energy through space or through some medium; for example, the emission and propagation of electromagnetic, sound, or elastic waves. 2. The energy transmitted through space or some medium; when unqualified, usually refers to electromagnetic radiation. Also known as radiant energy. 3. A stream of particles, such as electrons, neutrons, protons, alpha particles, or high-energy photons, or a mixture of these (McGraw-Hill 1989).

radioactivity-A particular type of radiation emitted by a radioactive substance, such as alpha radioactivity (McGraw-Hill 1989).

Radiation occurs naturally. It was not invented; rather, it was discovered. People are constantly exposed to radiation. For example, radon in air, potassium in food and water, and uranium, thorium, and radium in the earth's crust are all sources of radiation. The following discussion describes important aspects of radiation, including atoms and isotopes; types, sources, and pathways of radiation; radiation measurement; and dose information.

\section{ATOMS AND ISOTOPES}

All matter is made up of atoms. An atom is "a unit of matter consisting of a single nucleus surrounded by a number of electrons equal to the number of protons in the nucleus" (ANS 1986). The number of protons in the nucleus determines an element's atomic number, or chemical identity. With the exception of hydrogen, the nuclei of each type of atom also contains at least one neutron. Unlike protons, the number of neutrons may vary among atoms of the same element. The number of neutrons and protons determines the atomic weight. Atoms of the same element with a different number of neutrons are called isotopes. In other words, isotopes have the same chemical properties but different atomic weights. Figure A.1 depicts isotopes of the element hydrogen.

Another example is the element uranium, which has 92 protons; all isotopes of uranium, therefore, have 92 protons. However, each uranium isotope has a different number of neutrons. Uranium-234 has 92 protons and 142 neutrons; ${ }^{235} U$ has 92 protons and 143 neutrons; ${ }^{238} \mathrm{U}$ has 92 protons and 146 neutrons.

Some isotopes are stable, or nonradioactive; some are radioactive. Radioactive isotopes are called radionuclides, or radioisotopes. In an attempt to become stable, radionuclides "throw away," or emit, rays or particles. This emission of rays and particles is known as radioactive decay.

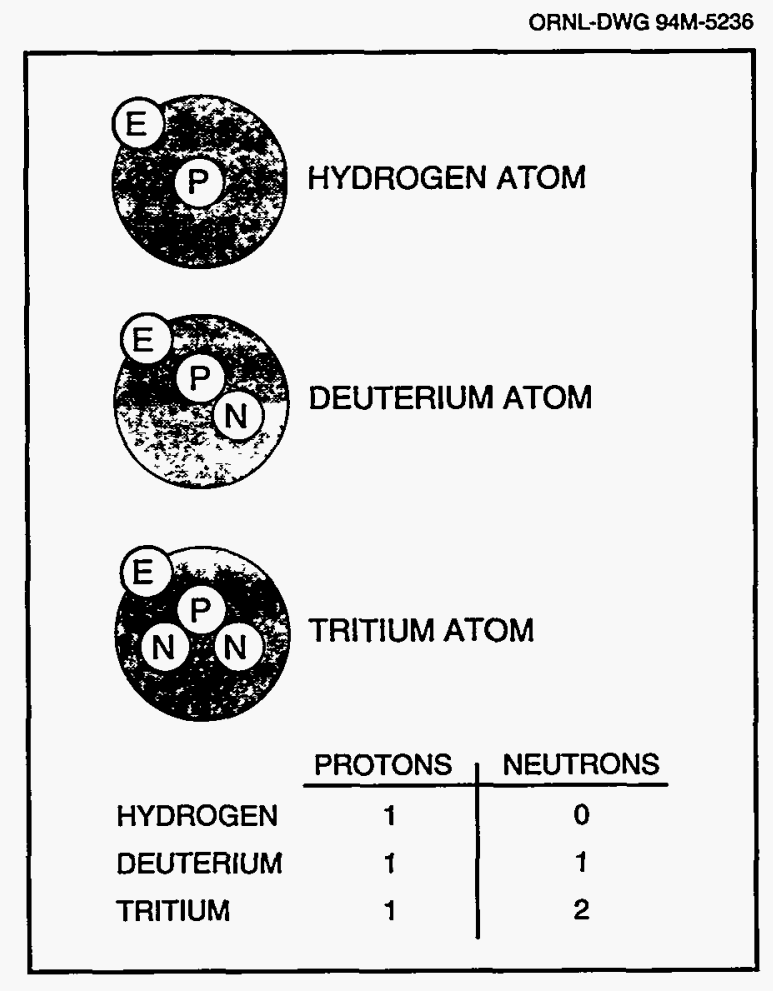

Fig. A.1. Isotopes of the element hydrogen. 


\section{RADIATION}

Radiation, or radiant energy, is energy in the form of waves or particles moving through space. Visible light, heat, radio waves, and alpha particles are examples of radiation. When people feel warmth from the sunlight, they are actually absorbing the radiant energy emitted by the sun.

Electromagnetic radiation is radiation in the form of electromagnetic waves; examples include gamma rays, ultraviolet light, and radio waves. Particulate radiation is radiation in the form of particles; examples include alpha and beta particles. Radiation also is characterized by the way in which it interacts with matter.

\section{Ionizing Radiation}

Normally, an atom has an equal number of protons and electrons; however, atoms can lose or gain electrons in a process known as ionization. Some forms of radiation can ionize atoms by "knocking" electrons off atoms. Examples of ionizing radiation include alpha, beta, and gamma radiation. Ionizing radiation is capable of changing the chemical state of matter and subsequently causing biological damage and thus is potentially harmful to human health. Figure A.2 shows the penetrating potential of different types of ionizing radiation.

\section{Nonionizing Radiation}

Nonionizing radiation bounces off of or passes through matter without displacing electrons. Examples include visible light and radio waves. Currently, it is unclear whether nonionizing radiation is harmful to human health. In the discussion that follows, the term radiation is used to describe ionizing radiation.

\section{SOURCES OF RADIATION}

Radiation is everywhere. Most occurs naturally, but a small percentage is human made. Naturally occurring radiation is known as background radiation.

\section{Background Radiation}

Many materials are naturally radioactive. In fact, this naturally occurring radiation is the major source of radiation in the environment. Though people have little control over the amount of background radiation to which they are exposed, this exposure must bè put into perspective.

Background radiation remains relatively constant over time; background radiation present in the environment today is much the same as it was hundreds of years ago.

Sources of background radiation include uranium in the earth, radon in the air, and potassium in food. Background radiation is categorized as cosmic, terrestrial, or internal, depending on its origin.

\section{A-2 Appendix A}

ORNL-DWG 94M-5237

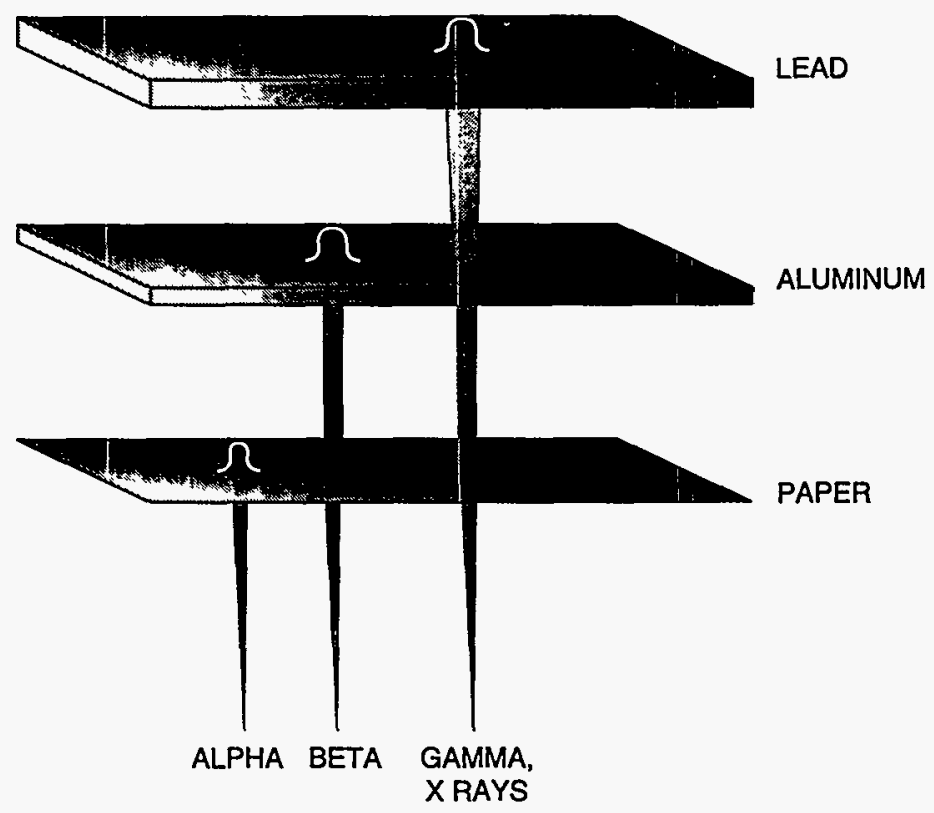

Fig. A.2. Penetrating power of radiation. Some types of radiation can be easily shielded against. For example, a sheet of paper is sufficient to stop an alpha particle. Gamma rays can pass through paper but can be stopped by the appropriate amount of lead. Radiation's ability to penetrate is an important consideration in protecting human health. Adequate shielding decreases the power of radiation by absorbing part or all of it. 


\section{Cosmic Radiation}

Energetically charged particles from outer space continuously hit the earth's atmosphere. These particles and the secondary particles and photons they create are called cosmic radiation. Because the atmosphere provides some shielding against cosmic radiation, the intensity of this radiation increases with altitude above sea level. In other words, a person in Denver, Colorado, is exposed to more cosmic radiation than a person in Death Valley, California.

\section{Terrestrial Radiation}

Terrestrial radiation refers to radiation emitted from radioactive materials in the earth's rocks, soils, and minerals. Radon $(\mathrm{Rn})$; radon progeny [the relatively short-lived decay products of radium-235 $\left({ }^{235} \mathrm{Ra}\right)$ ]; potassium $\left({ }^{40} \mathrm{~K}\right)$; isotopes of thorium $(\mathrm{Th})$; and isotopes of uranium $(\mathrm{U})$ are the elements responsible for most terrestrial radiation.

\section{Internal Radiation}

Radioactive material in the environment enters the body with the air people breathe and the food they eat; it also can enter through an open wound. Natural radionuclides in the body include isotopes of uranium, thorium, radium, radon, polonium, bismuth, and lead in the ${ }^{238} \mathrm{U}$ and ${ }^{232} \mathrm{Th}$ decay series. In addition, the body contains isotopes of potassium $\left({ }^{40} \mathrm{~K}\right)$, rubidium $\left({ }^{87} \mathrm{Rb}\right)$, and carbon $\left({ }^{14} \mathrm{C}\right)$.

\section{Human-Made Radiation}

In addition to background radiation, there are human-made sources of radiation to which most people are exposed. Examples include consumer products, medical sources, and fallout from atmospheric atomic bomb tests. (Atmospheric testing of atomic weapons has been suspended.) Also, about one-half of $1 \%$ of the U.S. population performs work in which radiation in some form is present.

\section{Consumer Products}

Some consumer products are sources of radiation. In some of these products, such as smoke detectors and airport X-ray baggage inspection systems, the radiation is essential to the performance of the device. In other products, such as televisions and tobacco products, the radiation occurs incidentally to the product function.

\section{Medical Sources}

Radiation is an important tool of diagnostic medicine and treatment and, in this use, is the main source of exposure to human-made radiation. Exposure is deliberate and directly beneficial to the patients exposed. Generally, medical exposures from diagnostic or therapeutic $\mathrm{X}$ rays result from beams directed to specific areas of the body. Thus, all body organs generally are not irradiated uniformly. Radiation and radioactive materials are also used in a wide variety of pharmaceuticals and in the preparation of medical instruments, including the sterilization of heat-sensitive products such as plastic heart valves. Nuclear medicine examinations and treatment involve the internal administration of radioactive compounds, or radiopharmaceuticals, by injection, inhalation, consumption, or insertion. Even then, radionuclides are not distributed uniformly throughout the body.

\section{Other Sources}

Other sources of radiation include fallout from atmospheric atomic bomb tests; emissions of radioactive materials from nuclear facilities such as uranium mines, fuel processing plants, and nuclear power plants; emissions from mineral extraction facilities; and transportation of radioactive materials. 
PATHWAYS OF RADIATION

Radiation and radioactive material in the environment can reach people through many routes. Potential routes for radiation are referred to as pathways. For example, radioactive material in the air could fall on a pasture. The grass could then be eaten by cows, and the radioactive material on the grass would show up in the cow's milk. People drinking the milk would thus be exposed to this radiation. Or, people could simply inhale the radioactive material in the air. The same events could occur with radioactive material in water. Fish living in the water would be exposed; people eating the fish would then be exposed to the radiation in the fish. Or, people swimming in the water would be exposed (see Fig. A.3).

\section{MEASURING RADIATION}

To determine the possible effects of radiation on the environment and the health of people, the radiation must be measured. More precisely, its potential to cause damage must be ascertained.

\section{Activity}

When measuring the amount of radiation in the environment, what is actually being measured is the rate of radioactive decay, or activity. The rate of decay varies widely among the various radioisotopes. For that reason, $1 \mathrm{~g}$ of a radioactive substance may contain the same amount of activity as several tons of another material. This activity is expressed in a unit of measure known as a curie (Ci). More specifically, $1 \mathrm{Ci}=3.7 \mathrm{E}+10(37,000,000,000)$ atom disintegrations per second (dps). In the international system of units, $1 \mathrm{dps}=1$ becquerel $(\mathrm{Bq})$.

\section{Absorbed Dose}

The total amount of energy absorbed per unit mass as a result of exposure to radiation is expressed in a unit of measure known as a rad. In the international system of units, $100 \mathrm{rad}=1$ gray (Gy). However, in terms of human health, it is the effect of the absorbed energy that is important because some forms of radiation are more harmful than others as a result of their energy deposition pattern.

\section{Dose Equivalent}

The measure of potential biological damage caused by exposure to and subsequent absorption of radiation is expressed in a unit of measure known as a rem. One rem of any type of radiation has the same total damaging effect. Because a rem represents a fairly large dose, dose is expressed as a millirem (mrem), or 1/1000 of a rem. In the international system of units, $100 \mathrm{rem}=1$ Sievert $(\mathrm{Sv}) ; 100 \mathrm{mrem}=1$ millisievert $(\mathrm{mSv})$.

\section{DOSE}

Many terms are used to report dose. Several factors are taken into account, including the amount of radiation absorbed, the organ absorbing the radiation, and the effect of the radiation over a 50-year period. The term "dose," in this report, includes the committed effective dose equivalent (EDE) and the effective dose equivalent attributable to penetrating radiation from sources external to the body.

\section{A-4 Appendix A}




\section{Dose Terminology \\ absorbed dose \\ dose equivalent \\ effective dose equivalent \\ committed dose equivalent \\ committed effective \\ dose equivalent \\ collective effective \\ dose equivalent \\ quality factor}

weighting factor quantity of radiation energy absorbed by an organ divided by an organ's mass absorbed dose to an organ multiplied by a quality factor single weighted sum of combined dose equivalents received by all organs effective dose equivalent to an organ over a 50-year period following intake total effective dose equivalent to all organs in the human body over a 50 -year period following intake

sum of effective dose equivalents of all members of a given population

a modifying factor used to adjust for the effect of the type of radiation, for example, alpha particles or gamma rays, on tissue

tissue-specific modifying factor representing the fraction of the total health risk from uniform, whole-body exposure

Determining dose is an involved process using complex mathematical equations based on several factors, including the type of radiation, the rate of exposure, weather conditions, and typical diet. Basically, radiant energy is generated from radioactive decay, or activity. People absorb some of the energy to which they are exposed. This absorbed energy is calculated as part of an individual's dose. Whether radiation is natural or human made, it has the same effect on people.

\section{Comparison of Dose Levels}

A scale of dose levels is presented in Table A.1. Included is an example of the type of exposure that may cause such a dose or the special significance of such a dose. This information is intended to help the reader become familiar with the type of doses individuals may receive.

\section{Dose from Cosmic Radiation}

The average annual dose received by residents of the United States from cosmic radiation is about 27 mrem (0.27 mSv) (NCRP 1987). The average annual dose from cosmic radiation received by residents in the Paducah area is about 45 mrem $(0.33 \mathrm{mSv})$.

\section{Dose from Terrestrial Radiation}

The average annual dose received from terrestrial gamma radiation is about $28 \mathrm{mrem}(0.28 \mathrm{mSv})$ in the United States. This dose varies geographically across the country (NCRP 1987); typical reported values are about 16 mrem $(0.16 \mathrm{mSv})$ at the Atlantic and Gulf coastal plains and about $63 \mathrm{mrem}(0.63 \mathrm{mSv})$ at the eastern slopes of the Rocky Mountains.

\section{Dose from Internal Radiation}

Short-lived decay products of radon are the major contributors to the annual dose equivalent for internal radionuclides (mostly ${ }^{222} \mathrm{Rn}$ ). They contribute an average dose of about $200 \mathrm{mrem}(2.00 \mathrm{mSv})$ per year. This dose estimate is based on an average radon concentration of about $1 \mathrm{pCi} / \mathrm{L}(0.037 \mathrm{~Bq} / \mathrm{L})(\mathrm{NCRP} 1987)$. 
The average dose from other internal radionuclides is about $39 \mathrm{mrem}(0.39 \mathrm{mSv})$ per year, most of which can be attributed to the naturally occurring isotope of potassium, ${ }^{40} \mathrm{~K}$. The concentration of radioactive potassium in human tissues is similar in all parts of the world.

\section{Dose from Consumer Products}

The U.S. average annual dose received by an individual from consumer products is about 10 mrem (0.10 mSv) (NCRP 1987).

\section{Dose from Medical Sources}

Nuclear medicine examinations, which involve the internal administration of radiopharmaceuticals, generally account for the largest portion of the dose received from human-made sources. However, the radionuclides used in specific tests are not distributed uniformly throughout the body. In these cases, comparisons are made using the concept of EDE, which relates exposure of organs or body parts to one effective whole-body dose. The average annual EDE from medical examinations is $53 \mathrm{mrem}(0.53 \mathrm{mSv})$, including $39 \mathrm{mrem}(0.39 \mathrm{mSv})$ for diagnostic $\mathrm{X}$ rays and $14 \mathrm{mrem}(0.14 \mathrm{mSv})$ for nuclear medicine procedures (NCRP 1989). The actual doses received by individuals who complete such medical exams are much higher than these values, but not everyone receives such exams each year (NCRP 1989).

\section{Dose from Other Sources}

Small doses received by individuals occur as a result of radioactive fallout from atmospheric atomic bomb tests, emissions of radioactive materials from nuclear facilities, emissions from certain mineral extraction facilities, and transportation of radioactive materials. The combination of these sources contributes less than $1 \mathrm{mrem}(0.01 \mathrm{mSv})$ per year to the average dose to an individual (NCRP 1987).

A comprehensive U.S. Environmental Protection Agency (EPA) report of 1984 projected the average occupational dose to monitored radiation workers in medicine, industry, the nuclear fuel cycle, government, and miscellaneous industries to be $105 \mathrm{mrem}(1.05 \mathrm{mSv})$ per year for 1985 , down slightly from $110 \mathrm{mrem}$ (1.10 mSv) per year in 1980 (Kumazawa et al. 1984). 
Table A.1. Comparison and description of various dose levels

Dose level

$1 \mathrm{mrem}(0.01 \mathrm{mSv})$

2.5 mrem $(0.025 \mathrm{mSv})$

10 mrem $(0.10 \mathrm{mSv})$

$45 \mathrm{mrem}(0.45 \mathrm{mSv})$

46 mrem (0.46 mSv)

66 mrem $(0.66 \mathrm{mSv})$

$100 \mathrm{mrem}(1.00 \mathrm{mSv})$

$110 \mathrm{mrem}(1.10 \mathrm{mSv})$

244 mrem (2.44 mSv)

300 mrem $(3.00 \mathrm{mSv})$

$1-5$ rem $(0.01-0.05 \mathrm{~Sv})$

$5 \mathrm{rem}(0.05 \mathrm{~Sv})$

10 rem $(0.10 \mathrm{~Sv})$

25 rem $(0.25 \mathrm{~Sv})$

75 rem $(0.75 \mathrm{~Sv})$

$50-600$ rem $(0.50-6.00 \mathrm{~Sv})$
Approximate daily dose from natural background radiation, including radon

Cosmic dose to a person on a one-way airplane flight from New York to Los Angeles

Annual exposure limit, set by the EPA for exposures from airborne emissions from operations of nuclear fuel cycle facilities, including power plants and uranium mines and mills

Average yearly dose from cosmic radiation received by people in the Paducah area

Estimate of the largest dose any off-site person could have received from the March 28,1979 , Three Mile Island nuclear power plant accident

Average yearly dose to people in the United States from human-made sources

Annual limit of dose from all U.S. Department of Energy facilities to a member of the public who is not a radiation worker

Average occupational dose received by U.S. commercial radiation workers in 1980

Average dose from an upper gastrointestinal diagnostic X-ray series

Average yearly dose to people in the United States from all sources of natural background radiation

EPA Protective Action Guidelines state that public officials should take emergency action when the dose to a member of the public from a nuclear accident will likely reach this range

Annual limit for occupational exposure of radiation workers set by the U.S. Nuclear Regulatory Commission and the U.S. Department of Energy

The BEIR V report estimated that an acute dose at this level would result in a lifetime excess risk of death from cancer, caused by the radiation, of $0.8 \%$ (BEIR 1990)

EPA guideline for voluntary maximum dose to emergency workers for non-lifesaving work during an emergency

EPA guideline for maximum dose to emergency workers volunteering for lifesaving work

Doses in this range received over a short period of time will produce radiation sickness in varying degrees. At the lower end of this range, people are expected to recover completely, given proper medical attention. At the top of this range, most people will die within 60 days 


\section{Appendix B: Chemical Release Data}

Table B.1. Superfund Amendments and Reauthorization Act, Title III, Section 313, chemical release information for 1993

\begin{tabular}{|c|c|c|c|c|}
\hline $\begin{array}{l}\text { Chemical } \\
\text { name }\end{array}$ & $\begin{array}{l}\text { Type of } \\
\text { release }\end{array}$ & $\begin{array}{l}\text { Quantity } \\
\text { released } \\
{[\mathrm{lb}(\mathrm{kg})]}\end{array}$ & $\begin{array}{l}\text { Major release } \\
\text { source }\end{array}$ & $\begin{array}{l}\text { Basis of } \\
\text { estimate }\end{array}$ \\
\hline \multirow[t]{4}{*}{ Chromium $^{a}$} & $\begin{array}{l}\text { Air: fugitive } \\
\text { emissions }\end{array}$ & $1900(860)$ & $\begin{array}{l}\text { Cooling tower } \\
\text { system }\end{array}$ & $\begin{array}{c}\text { Material } \\
\text { balance }\end{array}$ \\
\hline & $\begin{array}{l}\text { Water: Big Bayou } \\
\text { Creek }\end{array}$ & $0(0)$ & $\begin{array}{l}\text { C- } 616 \text { chromium } \\
\text { reduction } \\
\text { facility }\end{array}$ & Monitoring \\
\hline & $\begin{array}{l}\text { Water: Little } \\
\text { Bayou Creek }\end{array}$ & $0(0)$ & $\begin{array}{l}\text { Cooling tower } \\
\text { system }\end{array}$ & Monitoring \\
\hline & $\begin{array}{r}\text { Land: to } C-616 \\
\text { sludge lagoon }\end{array}$ & $7800(3500)$ & $\begin{array}{l}\text { C-616 chromium } \\
\text { reduction } \\
\text { facility sludge }\end{array}$ & Monitoring \\
\hline \multirow[t]{3}{*}{ Trichloroethylene } & Air: point source & $35,300(16,000)$ & $\begin{array}{l}\text { C-400 degreaser/ } \\
\text { storage tanks }\end{array}$ & $\begin{array}{l}\text { Material } \\
\text { balance }\end{array}$ \\
\hline & $\begin{array}{l}\text { Water: Big Bayou } \\
\text { Creek }\end{array}$ & $0(0)$ & $\begin{array}{l}\text { C-400 degreasing } \\
\text { operations }\end{array}$ & Monitoring \\
\hline & $\begin{array}{l}\text { Water: Little } \\
\text { Bayou Creek }\end{array}$ & $0(0)$ & $\begin{array}{l}\text { Degreasing } \\
\text { operations }\end{array}$ & Monitoring \\
\hline Sulfuric acid & $\begin{array}{l}\text { Air: fugitive } \\
\text { emissions }\end{array}$ & $620(280)$ & $\begin{array}{l}\text { Cooling tower } \\
\text { system }\end{array}$ & $\begin{array}{l}\text { Engineering } \\
\text { calculations }\end{array}$ \\
\hline \multirow[t]{3}{*}{ Chlorine } & $\begin{array}{l}\text { Air: fugitive } \\
\text { emissions }\end{array}$ & $5800(2600)$ & $\begin{array}{l}\text { Cooling tower } \\
\text { system }\end{array}$ & $\begin{array}{l}\text { Engineering } \\
\text { calculations }\end{array}$ \\
\hline & $\begin{array}{l}\text { Water: Big Bayou } \\
\text { Creek }\end{array}$ & $0(0)$ & $\begin{array}{l}\text { C-615 sewage } \\
\text { treatment plant }\end{array}$ & Monitoring \\
\hline & $\begin{array}{l}\text { Water: Little } \\
\text { Bayou Creek }\end{array}$ & $0(0)$ & $\begin{array}{l}\text { Once-through } \\
\text { cooling water }\end{array}$ & Monitoring \\
\hline Freon-114 & $\begin{array}{l}\text { Air: fugitive } \\
\text { emissions }\end{array}$ & $360,000(160,000)$ & Process cooling & $\begin{array}{c}\text { Engineering } \\
\text { calculations }\end{array}$ \\
\hline
\end{tabular}

${ }^{a}$ Quantity calculated as chromium; chemical compound is sodium bichromate. 
Table B.2. Superfund Amendments and Reauthorization Act, Section 312, tier two report for 1993

Chemical

Maximum amount on site at one time

\begin{tabular}{lr}
\hline Ammonia (anhydrous) & 5,000 \\
Calcium oxide & 216,587 \\
Chlorine & 50,000 \\
Dichlorotetrafluorethane & $75,520,000$ \\
Diesel fuel No. 2 & $3,059,316$ \\
Ferric sulfate & 117,533 \\
Ferrous sulfate & 50,000 \\
Gasohol & 50,000 \\
Hydrochloric acid & 50,000 \\
Kerosene & 50,000 \\
Lube oil & $3,029,832$ \\
Nitric acid & 5,000 \\
Nitrogen & 179,273 \\
Oxygen & 50,000 \\
Polychlorinated biphenyl & 753,367 \\
Propane & 50,000 \\
Sodium bisulfate & 50,000 \\
Sodium carbonate & 128,235 \\
Sodium hydroxide & 50,000 \\
Sulfuric acid & 500,000 \\
Trichloroethylene & 50,000 \\
Uranium hexafluoride & $903,000,000$ \\
Uranium tetrafluoride & $5,000,000$ \\
\hline
\end{tabular}




\section{Appendix C: Radionuclide and Chemical Nomenclature}

Nomenclature and half-life for radionuclides

\begin{tabular}{lll||lll}
\hline Radionuclide & Symbol & Half-life & Radionuclide & Symbol & Half-life \\
\hline Bismuth-210 & ${ }^{210} \mathrm{Bi}$ & 5.01 days & Radium-226 & ${ }^{226} \mathrm{Ra}$ & 1,602 years \\
Bismuth-214 & ${ }^{214} \mathrm{Bi}$ & 19.7 minutes & Radon-222 & ${ }^{2 m} \mathrm{Rn}$ & 3.821 days \\
Lead-206 & ${ }^{206} \mathrm{~Pb}$ & Stable & Technetium-99 & ${ }^{99} \mathrm{Tc}$ & 212,000 years \\
Lead-210 & ${ }^{210} \mathrm{~Pb}$ & 21 years & Thorium-230 & ${ }^{230} \mathrm{Th}$ & 80,000 years \\
Lead-214 & ${ }^{214} \mathrm{~Pb}$ & 26.8 minutes & Thorium-231 & ${ }^{231} \mathrm{Th}$ & 25.5 hours \\
Polonium-210 & ${ }^{210} \mathrm{Po}$ & 138.9 days & Thorium-234 & ${ }^{234} \mathrm{Th}$ & 24.1 days \\
Polonium-214 & ${ }^{214} \mathrm{Po}$ & 164 microseconds & Uranium-234 & ${ }^{234} \mathrm{U}$ & 247,000 years \\
Polonium-218 & ${ }^{218} \mathrm{Po}$ & 3.05 minutes & Uranium-235 & ${ }^{235} \mathrm{U}$ & $710,000,000$ years \\
Potassium-40 & ${ }^{40} \mathrm{~K}$ & $1,260,000,000$ years & Uranium-236 & ${ }^{236} \mathrm{U}$ & $23,900,000$ years \\
Protactinium-234m & ${ }^{234 m} \mathrm{~Pa}$ & 1.17 mimutes & Uranium-238 & ${ }^{238} \mathrm{U}$ & $4,510,000,000$ years \\
\hline
\end{tabular}

Nomenclature for elements and chemical constituents

\begin{tabular}{ll||ll}
\hline Constituent & $\mathrm{Symbol}$ & Constituent & $\mathrm{Symbol}$ \\
\hline Aluminum & $\mathrm{Al}$ & Manganese & $\mathrm{Mn}$ \\
Ammonia & $\mathrm{NH}_{3}$ & Mercury & $\mathrm{Hg}$ \\
Antimony & $\mathrm{Sb}$ & Nickel & $\mathrm{Ni}$ \\
Arsenic & $\mathrm{As}$ & Nitrogen & $\mathrm{N}$ \\
Barium & $\mathrm{Ba}$ & Nitrate & $\mathrm{NO}_{3}$ \\
Beryllium & $\mathrm{Be}$ & Nitrite & $\mathrm{NO}_{2}$ \\
Cadmium & $\mathrm{Cd}$ & Oxygen & $\mathrm{O}$ \\
Calcium & $\mathrm{Ca}$ & Ozone & $\mathrm{O}_{3}$ \\
Calcium carbonate & $\mathrm{CaCO}$ & Phosphorus & $\mathrm{P}$ \\
Carbon & $\mathrm{C}$ & Phosphate & $\mathrm{PO}$ \\
Chlorine & $\mathrm{Cl}$ & Potassium & $\mathrm{K}$ \\
Chromium & $\mathrm{Cr}$ & Radium & $\mathrm{Ra}$ \\
Chromium, hexavalent & $\mathrm{Cr}$ & Radon & $\mathrm{Rn}$ \\
Cobalt & $\mathrm{Co}$ & Selenium & $\mathrm{Se}$ \\
Copper & $\mathrm{Cu}$ & Silver & $\mathrm{Ag}$ \\
Fluorine & $\mathrm{F}$ & Sodium & $\mathrm{Na}$ \\
Hydrogen fluoride & $\mathrm{HF}$ & Sulfate & $\mathrm{SO}$ \\
Iron & $\mathrm{Fe}$ & Sulfur dioxide \\
Lead & $\mathrm{Pb}$ & Thorium & $\mathrm{SO}{ }_{2}$ \\
Lithium & $\mathrm{Li}$ & Uranium & $\mathrm{Th}$ \\
Magnesium & $\mathrm{Mg}$ & Zinc & $\mathrm{U}$ \\
\hline & & & $\mathrm{Zn}$ \\
\hline
\end{tabular}


L-a a xịpuədd $\forall$

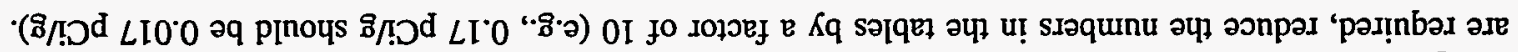

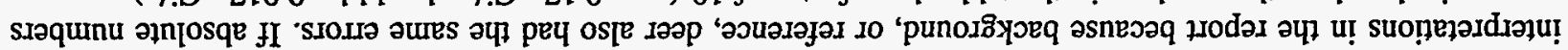

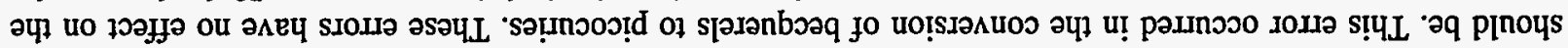

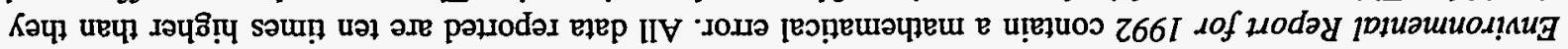

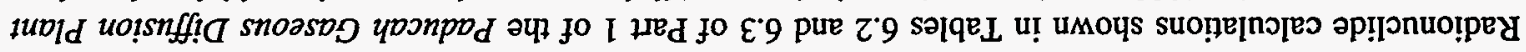

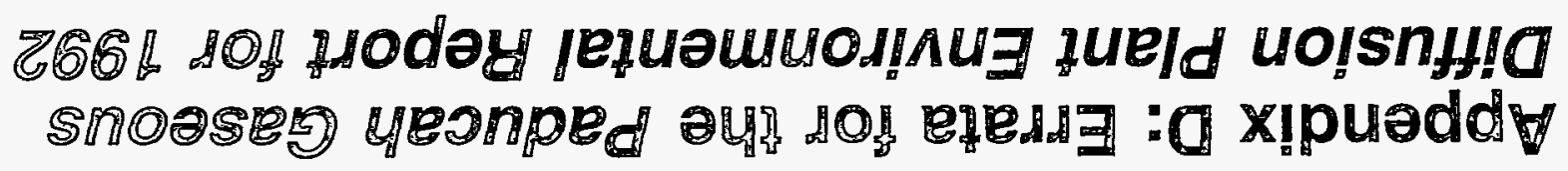




\section{References}

American Nuclear Society (ANS). 1986. Glossary of Terms in Nuclear Science and Technology. American Nuclear Society.

BEIR. 1990. Health Effects of Exposure to Low Levels of lonizing Radiation, Committee on the Biological Effects of Ionizing Radiation (BEIR V), National Research Council, National Academy of Sciences, National Academy Press, Washington, D.C.

CDM Federal Programs Corp. 1993. Resource Conservation and Recovery Act (RCRA) Facility Investigation Work Plan for Waste Area Groupings (WAGs) 1 and 7 and Kentucky Ordnance Works Solid Waste Management Units 94, 95, and 157 at the Paducah Gaseous Diffusion Plant, Paducah, Kentucky. DOE/OR/-7-1147\&D2, KY/ER-29\&D2, Martin Marietta Energy Systems, Inc. Paducah Gaseous Diffusion Plant.

CH2M Hill. 1990. Draft Results of the Site Investigation Phase I at the Paducah Gaseous Diffusion Plant, Paducah, Ky., KY/ER-4, Paducah Gaseous Diffusion Plant, Paducah, Ky.

CH2M Hill. 1991a. Results of the Public Health and Ecological Assessment, Phase II at the Paducah Gaseous Diffusion Plant (Draft), KY/SUB/13B-97777C P-03/1991/1.

CH2M Hill. 1991b. Results of the Site Investigation, Phase I, at the Paducah Gaseous Diffusion Plant, Paducah, Ky., KY/ER-4, Paducah Gaseous Diffusion Plant, Paducah, Ky.

CH2M Hill. 1992a. Results of the Site Investigation, Phase II, at the Paducah Gaseous Diffusion Plant, Paducah, Kentucky, KY/SUB/13B-97777C P-03/1991/1, Paducah Gaseous Diffusion Plant, Paducah, Ky.

CH2M Hill. 1992b. Results of the Public Health and Ecological Assessment, Phase II, at the Paducah Gaseous Diffusion Plant, Paducah, Kentucky, KY/SUB/13B-97777C P-03/1991/1, Paducah Gaseous Diffusion Plant, Paducah, Ky.

Clausen, J. L. 1992a. Paducah Gaseous Diffusion Plant Groundwater Protection Program Plan Addendum to Sampling and Analysis Plan. KY/ER-2/Addendum 1, Rev. 1, Martin Marietta Energy Systems, Inc., Paducah Gaseous Diffusion Plant.

Clausen, J. L. et al. 1992b. Report of the Paducah Gaseous Diffusion Plant Groundwater Investigation Phase III. KY/E-150, Martin Marietta Energy Systems, Inc., Paducah Gaseous Diffusion Plant.

Coker, C. B. 1988. Environmental Air Sampling, ES-1.R0, Paducah Gaseous Diffusion Plant, Paducah, Ky.

Department of Energy. 1994. Interim Corrective Measures Work Plan for the Northeast Plume Paducah Gaseous Diffusion Plant, Paducah, Kentucky. DOE/OR-1205\&D2, Department of Energy, Paducah, Kentucky.

Early, T. O., C. F. Sigmon, and R. T. Williams. 1989. Groundwater Monitoring Plan for the Paducah Gaseous Diffusion Plant, Paducah, Kentucky, Battelle Columbus Laboratories, Columbus, Ohio.

Fay, William M. and Kathleen Gore. 1992. Savannah River Site Environmental Report, Chap. 9, Groundwater. pp. 121, 124-126.

Feldhaus, T. L. 1994. US-DOE Paducah Environmental Restoration Regulatory Commitment Tracking System Report. DOE/OR/07-1225/V1, KY/ER-48 (Draft), Martin Marietta Energy Systems, Inc., Paducah Gaseous Diffusion Plant.

International Commission on Radiological Protection (ICRP). 1979. Annals of ICRP Publication 30, Parts I and II, Limits of Intakes of Radionuclides by Workers, ICRP Publication 30, Pergamon, Oxford, N.Y.

International Commission on Radiological Protection (ICRP). 1977. Annals of the ICRP 1, ICRP Publication 26, Pergamon, Oxford, N.Y.

Jinks, S. M., and M. Eisenbud. 1972. "Concentration Factors in Aquatic Environment," Radia Data Rep. 13, 243.

Kearl, P. M. 1993. Colloidal Borescope Investigation of Paducah Gaseous Diffusion Plant. Martin Marietta Energy Systems, Inc., Oak Ridge National Laboratory.

Klement, Alfred W., Jr., et al. August 1972. Estimates of lonizing Radiation Doses in the United States 1960-2000, Office of Radiation Programs, Rockville, Md.

Martin Marietta Energy Systems, Inc. (MMES). Sept. 1991. Paducah Gaseous Diffusion Plant Environmental Report for 1990. ES/ESH-18/V3, Martin Marietta Energy Systems, Inc. Paducah Gaseous Diffusion Plant.

Martin Marietta Energy Systems, Inc. (MMES). 1992a. Environmental Monitoring Plan, KY/E-118, Martin Marietta Energy Systems, Inc., Paducah Gaseous Diffusion Plant. 
Martin Marietta Energy Systems, Inc. 1992b. Site Management Plan. KY/ER-17, Martin Marietta Energy Systems, Inc., Paducah Gaseous Diffusion Plant.

Martin Marietta Energy Systems, Inc. 1993. Paducah Gaseous Diffusion Plant Environmental Report for 1992. ES/ESH-36, Martin Marietta Energy Systems, Inc. Paducah Gaseous Diffusion Plant.

McGraw-Hill. 1989. McGraw-Hill Dictionary of Scientific and Technical Terms, 4th ed. McGraw-Hill, Inc.

Miller, G. R. and J. W. Douthitt. 1993. Paducah Gaseous Diffusion Plant Groundwater Protection Program Management Plan, KY/ER-30, Martin Marietta Energy Systems, Inc., Paducah Gaseous Diffusion Plant.

National Council on Radiation Protection and Measurements (NCRP). 1987. "Ionizing Radiation Exposure of the Population of the United States," NCRP Report No. 93, Washington, D.C.

National Council on Radiation Protection and Measurements (NCRP). 1989. "Exposure of the U.S. Population from Diagnostic Medical Radiation," NCRP Report No. 100, Bethesda Md.

Olive, W. W. 1980. Geologic Maps of the Jackson Purchase Region, Kentucky, U.S. Department of the Interior, U.S. Geological Survey.

Paducah Gaseous Diffusion Plant (PGDP). 1979. Fluoride in Ambient Air. Gaseous and Water Soluble Particulate Treated Filter-SIE Method, EC-2360, Paducah, Ky.

Paducah Gaseous Diffusion Plant (PGDP). 1990. Low-Level Gross Alpha and Beta Activity on Air Filters, R-1-8, Paducah, Ky.

Science Applications International Corporation (SAIC). 1991a. Summary of Alternatives for Remediation of OffSite Contamination at the Paducah Gaseous Diffusion Plant, Paducah, Kentucky (Draft).

Science Applications International Corporation (SAIC). December 1991b. Summary of Phase II (Stage C) Activities, draft, Oak Ridge, Tenn.

Science Applications International Corporation (SAIC) 1992. Draft Environmental Assessment: Construction and Operation of Residential Landfill Cell No. 3 at the Paducah Gaseous Diffusion Plant, Paducah, Kentucky (Rev. 2), Oak Ridge, Tenn.

Science Applications International Corporation. 1993a. Groundwater Strategy Document for the Paducah Gaseous Diffusion Plant, Paducah, Kentucky. DOE/OR/07-1145\&D1, Martin Marietta Energy Systems, Inc. Paducah Gaseous Diffusion Plant.

Science Applications International Corporation. 1993b. Groundwater Surveillance for the Paducah Gaseous Diffusion Plant. KY/ER-38, Martin Marietta Energy Systems, Inc. Paducah Gaseous Diffusion Plant.

Science Applications International Corporation (SAIC). Oct. 12, 1993c. Interim Corrective Measures Report for Institutional Control of Off-Site Contamination in Surface Water, DOE/OR/07-1206\&D1, Paducah Gaseous Diffusion Plant, Paducah, Ky.

Science Applications International Corporation (SAIC). Mar. 17, 1993d. Proposed Plan for Interim Remedial Action of the Northwest Plume, DOE/OR/06-1127, Paducah Gaseous Diffusion Plant, Paducah, Ky.

Science Applications International Corporation. 1993e. Record of Decision for Interim Remedial Action of the Northwest Plume at Paducah Gaseous Diffusion Plant, Paducah, Kentucky. DOE/OR/06-1143\&D4, Science Applications International Corporation, Oak Ridge, Tenn.

Science Applications International Corporation (SAIC). Mar. 17, 1993f. Technical Memorandum for Interim Remedial Action of the Northwest Plume, DOE-OR 1031, Paducah Gaseous Diffusion Plant, Paducah, Ky.

U.S. Department of Energy (DOE). January 1991. Environmental Regulatory Guide for Radiological Effluent Monitoring and Environmental Surveillance. DOE/EH-0173T, Washington, D.C.

U.S. Department of Energy (DOE). July 1988. Internal Dose Conversion Factors for Calculations of Dose to the Public. DOE/EH-00071, U.S. DOE.

Young, S. C., H. E. Julian, and M. J. Neton. 1993. Application of the Electromagnetic Borehole Flowmeter and Evaluation of Previous Pumping Tests at Paducah Gaseous Diffusion Plant. Tennessee Valley Authority Engineering Laboratory, Norris, Tenn. 


\section{Glossary}

absorption-The process by which the number and energy of particles or photons entering a body of matter is reduced by interaction with the matter.

accuracy-The closeness of the result of a measurement to the true value of the quantity.

activity-See radioactivity.

aliquot-The quantity of sample being used for analysis that is representative of a larger quantity (e.g., 5 aliquots of 15 in the sample).

alkalinity-A measure of the buffering capacity of water; because $\mathrm{pH}$ has a direct effect on organisms as well as an indirect effect on the toxicity of certain other pollutants in the water, buffering capacity is important to water quality.

alpha particle-A positively charged particle emitted from the nucleus of an atom having the same charge and mass as that of a helium nucleus (two protons and two neutrons).

ambient air-The atmosphere around people, plants, and structures.

analytical detection limit-The lowest reasonably accurate concentration of an analyte that can be detected; this value varies depending on the method, instrument, and dilution used.

analyte-A constituent or parameter being analyzed.

anion-A negatively charged ion.

annealing--Maintenance of glass or metal at a specified temperature for a specific length of time followed by gradual cooling. This treatment removes internal strains and eliminates distortions and imperfections.

aquifer-A saturated, permeable geologic unit that can transmit significant quantities of water under ordinary hydraulic gradients.

aquitard-A geologic unit that inhibits the flow of water.

ash-Inorganic residue remaining after ignition of combustible substances.

assimilate-To take up or absorb.

atom-Smallest particle of an element capable of entering into a chemical reaction.

beta particle-A negatively charged particle emitted from the nucleus of an atom. It has a mass and charge equal to those of an electron.

biomass-The weight of any specific or general kind of organic matter, usually expressed per area or volume.

biota-The animal and plant life of a particular region considered as a total ecological entity.

blank-A control sample that is identical, in principle, to the sample of interest, except that the substance being analyzed is absent. In such cases, the measured value or signal for the substance being analyzed is believed to be a result of artifacts. Under certain circumstances, that value may be subtracted from the measured value to give a net result reflecting the amount of the substance in the sample. The U.S. Environmental Protection Agency (EPA) does not permit the subtraction of blank results in EPA-regulated analyses.

calibration-Determination of variance from a standard of accuracy of a measuring instrument to ascertain necessary correction factors. 
carcinogen-A cancer-causing substance.

cation-A positively charged ion.

CERCLA-reportable release-A release to the environment that exceeds reportable quantities as defined by CERCLA (Comprehensive Environmental Response, Compensation, and Liability Act).

chain of custody-A form that documents sample collection, transport, analysis, and disposal.

chemical oxygen demand-The quantity of oxidizable materials present in water; varies with water composition, concentrations of reagent, temperature, period of contact, and other factors.

chemical speciation-The occurrence of chemical elements in different forms or species (e.g., elemental ionic, complexed), depending on environmental conditions.

chlorocarbons-Compounds of carbon and chlorine or carbon, hydrogen, and chlorine, such as carbon tetrachloride, chloroform, and tetrachloroethylene. They are among the most significant and widespread environmental contaminants and are classified as hazardous wastes. Chlorocarbons may have a tendency to cause detrimental effects, such as birth defects.

Ci-See curie.

closure—Control of a hazardous waste management facility under RCRA requirements.

COD—See chemical oxygen demand.

compliance-Fulfillment of applicable requirements of a plan or schedule ordered or approved by government authority.

concentration-The amount of a substance contained in a unit volume or mass of a sample.

conductivity-A measure of water's capacity to convey an electric current. This property is related to the total concentration of the ionized substances in water and the temperature at which the measurement is made.

confluence-The point at which two or more streams meet; the point where a tributary joins the main stream.

contamination-Deposition of unwanted material on the surfaces of structures, areas, objects, or personnel.

control limits-A statistical tool used to define the bounds of virtually all values produced by a system in statistical control.

cosmic radiation-Ionizing radiation with very high energies, originating outside the earth's atmosphere. Cosmic radiation is one contributor to natural background radiation.

count-The signal that announces an ionization event within a counter; a measure of the radiation from an object or device.

counter-A general designation applied to radiation detection instruments or survey meters that detect and measure radiation.

counting geometry-A well-defined sample size and shape for which a counting system has been calibrated.

curie (Ci)-A unit of radioactivity. One curie is defined as $3.7 \times 10^{10}$ (37 billion) disintegrations per second. Several fractions and multiples of the curie are commonly used: 
kilocurie ( $\mathrm{kCi})-10^{3} \mathrm{Ci}$, one thousand curies; $3.7 \times 10^{13}$ disintegrations per second.

millicurie ( $\mathrm{mCi})-10^{-3} \mathrm{Ci}$, one-thousandth of a curie; $3.7 \times 10^{7}$ disintegrations per second.

microcurie $(\mu \mathrm{Ci})-10^{-6} \mathrm{Ci}$, one-millionth of a curie; $3.7 \times 10^{4}$ disintegrations per second.

picocurie ( $\mathbf{p C i})-10^{-12} \mathrm{Ci}$, one-trillionth of a curie; 0.037 disintegrations per second.

2,4-D-2,4-Dichlorophenoxyacetic acid.

daughter-A nuclide formed by the radioactive decay of a parent nuclide.

DCG-See derived concentration guideline.

decay, radioactive-The spontaneous transformation of one radionuclide into a different radioactive or nonradioactive nuclide or into a different energy state of the same radionuclide.

decontamination and decommissioning-See Environmental Restoration.

dense nonaqueous phase liquid (DNAPL) - The liquid phase of chlorinated organic solvents. These liquids are denser than water and include commonly used industrial compounds such as tetrachloroethylene and trichloroethylene.

derived concentration guideline (DCG)-The concentration of a radionuclide in air or water that under conditions of continuous exposure for one year by one exposure mode (i.e., ingestion of water, submersion in air or inhalation) would result in either an effective dose equivalent of $0.1 \mathrm{rem}(1 \mathrm{mSv})$ or a dose equivalent of 5 rem $(50 \mathrm{mSv})$ to any tissue, including skin and the lens of the eye. The guidelines for radionuclides in air and water are given in DOE Order 5400.5.

desorption-The process of removing a sorbed substance by the reverse of adsorption or absorption.

detector-Material or device (instrument) that is sensitive to radiation and can produce a signal suitable for measurement or analysis.

dilution factor-The mathematical factor by which a sample is diluted to bring the concentration of an analyte in a sample within the analytical range of a detector (e.g., $1 \mathrm{~mL}$ sample $+9 \mathrm{~mL}$ solvent $=1: 10$ dilution, or a dilution factor of 10 ).

disintegration, nuclear-A spontaneous nuclear transformation (radioactivity) characterized by the emission of energy and/or mass from the nucleus of an atom.

dissolved oxygen-A desirable indicator of satisfactory water quality in terms of low residuals of biologically available organic materials. Dissolved oxygen prevents the chemical reduction and subsequent leaching of iron and manganese from sediments.

DNAPL—See dense nonaqueous phase liquid.

dose-The energy imparted to matter by ionizing radiation. The unit of absorbed dose is the rad, equal to 0.01 joules per kilogram in any medium.

absorbed dose-The quantity of radiation energy absorbed by an organ divided by the organ's mass. Absorbed dose is expressed in units of rad (or gray) ( $1 \mathrm{rad}=0.01 \mathrm{~Gy}$ ).

dose equivalent-The product of the absorbed dose (rad) in tissue and a quality factor. Dose equivalent is expressed in units of rem (or sievert) $(1 \mathrm{rem}=0.01 \mathrm{~Sv})$.

committed dose equivalent-The calculated total dose equivalent to a tissue or organ over a 50 -year period after known intake of a radionuclide into the body. Contributions from external dose are not included.

Committed dose equivalent is expressed in units of rem (or sievert). 
committed effective dose equivalent-The sum of the committed dose equivalents to various tissues in the body, each multiplied by the appropriate weighting factor. Committed effective dose equivalent is expressed in units of rem (or sievert).

effective dose equivalent-The sum of the dose equivalents received by all organs or tissues of the body after each one has been multiplied by an appropriate weighting factor. The effective dose equivalent includes the committed effective dose equivalent from internal deposition of radionuclides and the effective dose equivalent attributable to sources external to the body.

collective dose equivalent/collective effective dose equivalent-The sums of the dose equivalents or effective dose equivalents of all individuals in an exposed population within a 50 -mile $(80-\mathrm{km})$ radius expressed in units of person-rem (or person-sievert). When the collective dose equivalent of interest is for a specific organ, the units would be organ-rem (or organ-sievert). The 50-mile distance is measured from a point located centrally with respect to major facilities or DOE program activities.

dosimeter-A portable detection device for measuring the total accumulated exposure to ionizing radiation.

dosimetry-The theory and application of principles and techniques involved in the measurement and recording of radiation doses. Its practical aspect is concerned with using various types of radiation instruments to make measurements.

downgradient-In the direction of decreasing hydrostatic head.

downgradient well-A well that is installed hydraulically downgradient of a site and that may be capable of detecting migration of contaminants from a site.

drinking water standards (DWS)-Federal primary drinking water standards, both proposed and final, as set forth by the EPA.

DWS-See drinking water standards.

effluent-A liquid or gaseous waste discharge to the environment.

effluent monitoring-The collection and analysis of samples or measurements of liquid and gaseous effluents for purposes of characterizing and quantifying the release of contaminants, assessing radiation exposures of members of the public, and demonstrating compliance with applicable standards.

Environmental Restoration-A DOE program that directs the assessment and cleanup of its sites (remediation) and facilities (decontamination and decommissioning) contaminated with waste as a result of nuclear-related activities.

equipment blank-A sample container of deionized water that has been pumped through or has filled a sampling device (e.g., well pump bailer). Laboratory analysis of the blank can identify potential contaminants in water, sample container, or analytical equipment.

exposure (radiation)-The incidence of radiation on living or inanimate material by accident or intent. Background exposure is the exposure to natural background ionizing radiation. Occupational exposure is that exposure to ionizing radiation that takes place at a person's workplace. Population exposure is the exposure to the total number of persons who inhabit an area.

external radiation-Exposure to ionizing radiation when the radiation source is located outside the body.

fauna-The population of animals at a given area, environment, formation, or time span.

fecal coliform-The coliform group comprises all of the aerobic, non-spore-forming, rod-shaped bacteria. The test determines the presence or absence of coliform organisms.

\section{G-4 Glossary}


field blank-A sample container of deionized water generated by filling the sample container at the sample location and treated as a groundwater sample.

fixed residue-Material left in the vessel after evaporating a water sample and its subsequent ashing in an oven at a high temperature. Waters yielding considerable residue are generally inferior with respect to palatability, or they may induce an unfavorable physiological reaction in the transient consumer.

flora-The population of plants at a given area, environment, formation, or time span.

formation-A mappable unit of consolidated or unconsolidated geologic material of a characteristic lithology or assemblage of lithologies.

gamma ray-High-energy, short-wavelength electromagnetic radiation emitted from the nucleus of an excited atom. Gamma rays are identical to $\mathrm{X}$ rays except for the source of the emission.

gamma spectrometry-A system consisting of a detector, associated electronics, and a multichannel analyzer that is used to analyze samples for gamma-emitting radionuclides.

Gaussian puff/plume model-A computer-simulated atmospheric dispersion of a release using a Gaussian (normal) statistical distribution to determine concentrations in air.

Geiger-Mueller (GM) counter-A highly sensitive, gas-filled radiation detector that operates at voltages sufficiently high to produce ionization. The counter is used primarily in the detection of gamma radiation and beta emission. It is named for Hans Geiger and W. Mueller, who invented it in 1928.

grab sample-A sample collected instantaneously with a glass or plastic bottle placed below the water surface to collect surface water samples (also called dip samples).

groundwater, unconfined-Groundwater exposed to the unsaturated zone.

half-life, radiological-The time required for half of a given number of atoms of a specific radionuclide to decay. Each nuclide has a unique half-life.

halogenated compound-An organic compound bonded with one of the five halogen elements (astatine, bromine, chlorine, fluorine, and iodine).

halomethane-Any compound that includes a methane group $\left(\mathrm{CH}_{3}\right)$ bonded to a halogen element (astatine, bromine, chlorine, fluorine, or iodine).

heavy water-Water in which the molecules contain oxygen and deuterium, an isotope of hydrogen that is heavier than ordinary hydrogen.

hydrology - The science dealing with the properties, distribution, and circulation of natural water systems.

hydrogeology-Hydraulic aspects of site geology.

in situ-In its original place; field measurements taken without removing the sample from its origin; remediation performed while groundwater remains below the surface.

internal blank-Deionized water sample generated by the laboratory; an internal blank is analyzed with each batch of samples as an in-house check of analytical procedures and equipment.

internal dose factor-A factor used to convert intakes of radionuclides to dose equivalents. 
internal radiation-Occurs when natural radionuclides enter the body by ingestion of food, milk, or water or by inhalation. Radon is the major contributor to the annual dose equivalent for internal radionuclides.

ion-An atom or compound that carries an electrical charge.

ion exchange-A process in which a solution containing soluble ions is passed over a solid ion exchange column that removes the soluble ions by exchanging them with labile ions from the surface of the column. The process is reversible so that the trapped ions are removed from the column and the column is regenerated.

irradiation-Exposure to radiation.

isotopes-Forms of an element having the same number of protons but differing numbers of neutrons in their nuclei.

long-lived isotope-A radionuclide that decays at such a slow rate that a quantity of it will exist for an extended period (half-life is greater than three years).

short-lived isotope-A radionuclide that decays so rapidly that a given quantity is transformed almost completely into decay products within a short period (half-life is two days or less).

laboratory blank-See internal blank.

LLD-See lower limit of detection.

lower limit of detection (LLD)-The smallest concentration or amount of analyte that can be reliably detected in a sample at a $95 \%$ confidence level.

macroinvertebrates-A size-based classification used for a variety of insects and other small invertebrates; as defined by EPA, those organisms that are retained by a No. 30 (590 micron) U.S. standard sieve.

maximally exposed individual-A hypothetical individual who remains in an uncontrolled area and would, when all potential routes of exposure from a facility's operations are considered, receive the greatest possible dose equivalent.

mean relative difference (MRD) - a percentage error based on statistical analysis.

mercury-A silver-white liquid metal solidifying at $-38.9^{\circ} \mathrm{C}$ to form a tin-white, ductile, malleable mass. It is widely distributed in the environment and biologically is a nonessential or nonbeneficial element. Human poisoning caused by this highly toxic element has been clinically recognized.

microbes-Microscopic organisms.

migration-The transfer or movement of a material through air, soil, or groundwater.

milliroentgen ( $\mathbf{m R}$ )-A measure of X-ray or gamma radiation. The unit is one-thousandth of a roentgen.

minimum detectable concentration-The smallest amount or concentration of a radionuclide that can be distinguished in a sample by a given measurement system at a preselected counting time and at a given confidence level.

monitoring-Process whereby the quantity and quality of factors that can affect the environment and/or human health are measured periodically to regulate and control potential impacts.

MRD-See mean relative difference.

mrem-The dose equivalent that is one-thousandth of a rem. 
natural radiation-Radiation from cosmic and other naturally occurring radionuclide (such as radon) sources in the environment.

nonstochastic effects-Biological effects in which the severity in affected individuals varies with the magnitude of the dose above a threshold.

nuclide-An atom specified by its atomic weight, atomic number, and energy state. A radionuclide is a radioactive nuclide.

outcrop—A place where groundwater is discharged to the surface. Springs, swamps, and beds of streams and rivers are the outcrops of the water table.

outfall-The point of conveyance (e.g., drain or pipe) of wastewater or other effluents into a ditch, pond, or river.

part per billion (ppb) - A unit measure of concentration equivalent to the weight/volume ratio expressed as $g / L$ or $\mathrm{ng} / \mathrm{mL}$.

part per million (ppm)-A unit measure of concentration equivalent to the weight/volume ratio expressed as $\mathrm{mg} / \mathrm{L}$.

person-rem-Collective dose to a population group. For example, a dose of 1 rem to 10 individuals results in a collective dose of 10 person-rem.

pH-A measure of the hydrogen ion concentration in an aqueous solution. Acidic solutions have a $\mathrm{pH}$ from 0 to 6, neutral solutions have a $\mathrm{pH}$ equal to 7 , and basic solutions have a $\mathrm{pH}>7$.

piezometer-An instrument used to measure the potentiometric surface of the groundwater; also, a well designed for this purpose.

point of compliance-A vertical surface located at the hydraulically downgradient limit of the waste management area that extends down into the uppermost aquifer underlying the regulated units.

population dose commitment-See collective dose equivalent.

ppb-See part per billion.

ppm-See part per million.

precision-The closeness of approach of a value of similar or replicate results to a common value in a series of measurements.

process water-Water used within a system process.

process sewer-Pipe or drain, generally located underground, used to carry off process water or waste matter.

purge-To remove water before sampling, generally by pumping or bailing.

QA-See quality assurance.

QC-See quality control.

quality assurance (QA) - Any action in environmental monitoring to ensure the reliability of monitoring and measurement data. 
quality control $(\mathrm{QC})$-The routine application of procedures within environmental monitoring to obtain the required standards of performance in monitoring and measurement processes.

quality factor-The factor by which the absorbed dose (rad) is multiplied to obtain a quantity that expresses, on a common scale for all ionizing radiation, the biological damage to exposed persons. It is used because some types of radiation, such as alpha particles, are more biologically damaging than others.

rad-The unit of absorbed dose deposited in a volume of material.

radiation detection instruments-Devices that detect and record the characteristics of ionizing radiation.

radioactivity-The spontaneous emission of radiation, generally alpha or beta particles or gamma rays, from the nucleus of an unstable isotope.

radioisotopes-Radioactive isotopes.

radionuclide—An unstable nuclide capable of spontaneous transformation into other nuclides by changing its nuclear configuration or energy level. This transformation is accompanied by the emission of photons or particles.

RCRA-See Resource Conservation and Recovery Act.

reagent-Any substance used in a chemical reaction to detect or measure another substance or to convert one substance into another by means of the reaction that it causes.

reagent blank-A control sample used to determine the background of each reagent or solvent used in a given method of analysis. They are composed of all constituents that will contact the sample except the sample itself.

reclamation-Recovery of wasteland, desert, etc., by ditching, filling, draining, or planting.

reference material-A material or substance with one or more properties that are sufficiently well established and used to calibrate an apparatus, to assess a measurement method, or to assign values to materials.

release-Any discharge to the environment. Environment is broadly defined as any water, land, or ambient air.

rem-The unit of dose equivalent (absorbed dose in rads $\times$ the radiation quality factor). Dose equivalent is frequently reported in units of millirem (mrem), which is one-thousandth of a rem.

remediation-The correction of a problem. See Environmental Restoration.

replicate-In groundwatet monitoring programs, a second sample taken from the same well at the same time as the primary sample and sent to the same laboratory for analysis.

replicate result-The analytical result of a blind replicate sample.

resin-An organic polymer used as an ion-exchange material.

Resource Conservation and Recovery Act (RCRA)—Federal legislation that regulates the transport, treatment, and disposal of solid and hazardous wastes.

RFI Program-RCRA Facility Investigation Program; EPA-regulated investigation of a solid waste management unit with regard to its potential impact on the environment.

roentgen- $\mathrm{A}$ unit of exposure from $\mathrm{X}$ or gamma rays. One roentgen equals $2.58 \times 10^{-4}$ coulombs per kilogram of air. 
routine radioactive release-A planned or scheduled release of radioactivity to the environment.

screen zone-In well construction, the section of a formation that contains the screen, or perforated pipe, that allows water to enter the well.

seepage basin-An excavation that receives wastewater. Insoluble materials settle out on the floor of the basin, and soluble materials seep with the water through the soil column where they are removed partially by ion exchange with the soil. Construction may include dikes to prevent overflow or surface runoff.

self-absorption-Absorption of radiation by the sample itself, preventing detection by the counting instrument.

sensitivity-The capability of methodology or instruments to discriminate between samples with differing concentrations or containing varying amounts of an analyte.

settleable solids—Material settling out of suspension within a defined period.

settling basin -A temporary holding basin (excavation) that receives wastewater that is subsequently discharged.

sidegradient well-A well that intercepts groundwater flowing next to a site; a sidegradient well is located neither upgradient nor downgradient to the monitored site.

sievert (Sv)-The SI (International System of Units) unit of dose equivalent; $1 \mathrm{~Sv}=100 \mathrm{rem}$.

slurry-A suspension of solid particles (sludge) in water.

Solid Waste Disposal Facility (SWDF)-A place for burying unwanted radioactive material to prevent escape of radioactivity. The surrounding water acts as a shield. Such material is placed in watertight, noncorrodible containers so that it cannot leach out and invade underground water.

source-A point or object from which radiation or contamination emanates.

source check-A radioactive source with a known amount of radioactivity used to check the performance of the radiation detector instrument.

source term-Quantity of radioactivity released in a set period of time that is traceable to the starting point of an effluent stream or migration pathway.

specific conductance-The ability of water to conduct electricity; this ability varies in proportion to the amount of ionized minerals in the water.

spike-The addition of a known amount of reference material containing the analyte of interest to a blank sample.

split sample-Two samples from the same well taken at the same time and sent to two different laboratories for analysis.

stable-Not radioactive or not easily decomposed or otherwise modified chemically.

stack-A vertical pipe or flue designed to exhaust airborne gases and suspended particulate matter.

standard deviation-An indication of the dispersion of a set of results around their average.

standard reference material (SRM)-A reference material distributed and certified by the National Institute of Standards and Technology. 
stochastic effects-Biological effects the probability of which, rather than the severity, is a function of the magnitude of the radiation dose without threshold (i.e., stochastic effects are random in nature).

storm water runoff-Surface streams that appear after precipitation.

strata-Beds, layers, or zones of rocks.

substrate-The substance, base, surface, or medium in which an organism lives and grows.

sulfate-Compound containing the $-\mathrm{SO}_{4}$ group (e.g., $\mathrm{Na}_{2} \mathrm{SO}_{4}$ ); widely distributed in nature and may be present in natural waters in concentrations ranging from a few to several thousand milligrams per liter.

supernatant-The portion of a liquid above settled materials in a tank or other vessel.

surface water-All water on the surface of the earth, as distinguished from groundwater.

suspended solids-Fine, nonsettling particles of any solid within a liquid or gas.

Sv-See sievert.

SWDF-See Solid Waste Disposal Facility.

tank farm-An installation of interconnected underground tanks for storage of high-level radioactive liquid wastes.

terrestrial radiation-Ionizing radiation emitted from radioactive materials, primarily ${ }^{40} \mathrm{~K}$, thorium, and uranium, in the earth's soils. Terrestrial radiation contributes to natural background radiation.

thermoluminescent dosimeter (TLD)-A device used to measure external gamma radiation.

TLD-See thermoluminescent dosimeter.

total activity-The total quantity of radioactive decay particles that are emitted from a sample.

total dissolved solids-Dissolved solids and total dissolved solids are terms generally associated with freshwater systems and consist of inorganic salts, small amounts of organic matter, and dissolved materials.

total organic halogens-A measure of the total concentration of organic compounds that have one or more halogen atoms.

total solids-The sum of total dissolved solids and suspended solids.

total suspended particulates-Refers to the concentration of particulates in suspension in the air irrespective of the nature, source, or size of the particulates.

transuranic waste-Solid radioactive waste containing primarily alpha-emitting elements heavier than uranium.

transuranic elements-Elements with higher atomic weights than uranium; all 13 known transuranic elements are radioactive and are produced artificially.

tritium $\left({ }^{3} \mathrm{H}\right)$-The hydrogen isotope with one proton and two neutrons in the nucleus. It emits a low-energy beta particle $(0.0186 \mathrm{MeV}$ max) and has a half-life of 12.5 years.

t-test-Statistical method used to determine if the means of groups of observations are equal. 
turbidity-A measure of the concentration of sediment or suspended particles in solution.

upgradient-In the direction of increasing hydrostatic head.

vadose zone-Soil zone located above the water table.

variation-The divergence in the structural or functional characteristics of an organism from those considered typical of the group to which it belongs.

volatile organic compounds-1,1,1-TCA, perclene, and triclene are common names for trichloroethane, tetrachloroethylene, and trichloroethylene, respectively. Used in many processes, the levels of these carcinogenic compounds must be kept to a minimum. They are measured by volatile organic analyses content.

watershed-The region draining into a river, river system, or body of water.

wetlands-A lowland area, such as a marsh or swamp, inundated or saturated by surface or groundwater sufficiently to support hydrophytic vegetation typically adapted to life in saturated soils.

wind rose-A diagram in which statistical information concerning direction and speed of the wind at a location is summarized. 


\section{Internal Distribution}

1. T. A. Acox

2. D. L. Armstrong

3. D. L. Ashburn

4. J. B. Atwater

5. M. L. Baker

6. F. P. Baxter

7. D. E. Beck

8. C. R. Bieber

9. T. J. Blasing

10. C. W. Broughton

11. B. M. Burchell

12. W. W. Chance

13. D. E. Conrad

14. N. H. Cutshall

15. M. P. DeLozier

16. R. J. Devol

17. F. Dickens

18. R. C. Durfee

19. T. O. Early

20. T. L. Fletcher

21. C. J. Ford

22. M. W. Francis

23. D. W. Frazier

24. C. E. Frye

25. L. K. Garner

26. C. G. Giltner

27. R. W. Glass

28. G. A. Goslow

29. P. A. Gourieux

30. R. L. Grant

31. D. R. Guminski

32. J. L. Haymore

33. S. G. Hildebrand

34. C. C. Hill

35. R. L. Hinzman

36. J. W. Hodge

37. F. Homerosky, Jr.

38. C. M. Horak

39. K. Horsley

40. D. D. Huff

41. W. K. Jago

42. C. G. Jones

43. D. W. Jones

44. R. H. Kingrea

45. A. F. Kiriluk

46. M. E. Kirker

47. K. L. Kliewer

48. W. S. Koncinski

49. E. H. Krieg, Jr.

50. S. Y. Lee

51. J. M. Loar

52. L. W. Long
53. P. Y. Lu

54. A. P. Malinauskas

55. W. D. Malis

56. F. K. Martin

57. D. C. Mason

58. J. C. Massey

59. J. G. McDonald

60. L. W. McMahon

61. S. A. Meacham

62. L. J. Mezga

63. J. L. Miranda

64. G. L. Murphy

65. J. B. Murphy

66. C. E. Nix

67. F. R. O'Donnell

68. S. E. Payne

69. S. R. Penrod

70. D. C. Pentecost

71. M. J. Peterson

72. G. V. Pierce

73. S. Polston

74. P. Potter

75. J. E. Powell

76. R. E. Pudelek

77. H. Pulley

78. R. Richmond

79. J. G. Rogers

80. J. E. Rushton

81. G. E. Rymer

82. L. B. Ryon

83. D. R. Sampson

84. E. M. Schilling

85. S. L. Shell

86. C. W. Sheward

87. L. G. Shipe

88. S. P. N. Singh

89. N. L. Sinor

90. E. L. Smith, Jr.

91-92. M. C. Smith

93. G. W. Snyder

94. M. L. Socolof

95. G. R. Southworth

96. A. J. Stewart

97. L. E. Stokes

98. S. H. Stow

99. R. C. Summers

100. F. G. Taylor, Jr.

101. K. M. Tomko

102. C. C. Travis

103. J. H. Turner

104. C. J. Van Meter

105. C. W. Weber 
106. L. Welch

107-156. D. C. West

157. D. A. White

158. R. K. White

159. J. K. Williams

160. W. R. Williams

161. S. L. Winters

162. P. D. Wooldridge

163. Central Research Library

164. DOE K-25 Site Office

165. DOE Y-12 Site Office
166. ORNL ESD Library

167-169. ORNL Laboratory Records

170. ORNL Laboratory Records-RC

171. ORNL Patent Section

172. ORNL Y-12 Technical Library

173. PGDP ER-DMC

174. PGDP Library

175. Portsmouth Library

176. K-25 CEP Document Center

177. K-25 Site Library

External Distriburion

178. Office of Assistant Manager for Energy Research and Development, U.S. Department of Energy Oak Ridge Operations, P.O. Box 2001, Oak Ridge, TN 37831-8600.

179-180. Office of Scientific and Technical Information, P.O. Box 62, Oak Ridge, TN 37831.

181-280. This report is distributed widely by the Department of Energy's Oak Ridge Operations Office to local, state, and federal government agencies; the Congress; the public; and the news media. 